\title{
Indian Renewable Energy Status Report Background Report for DIREC 2010
}

NREL/TP-6A20-48948

October 2010

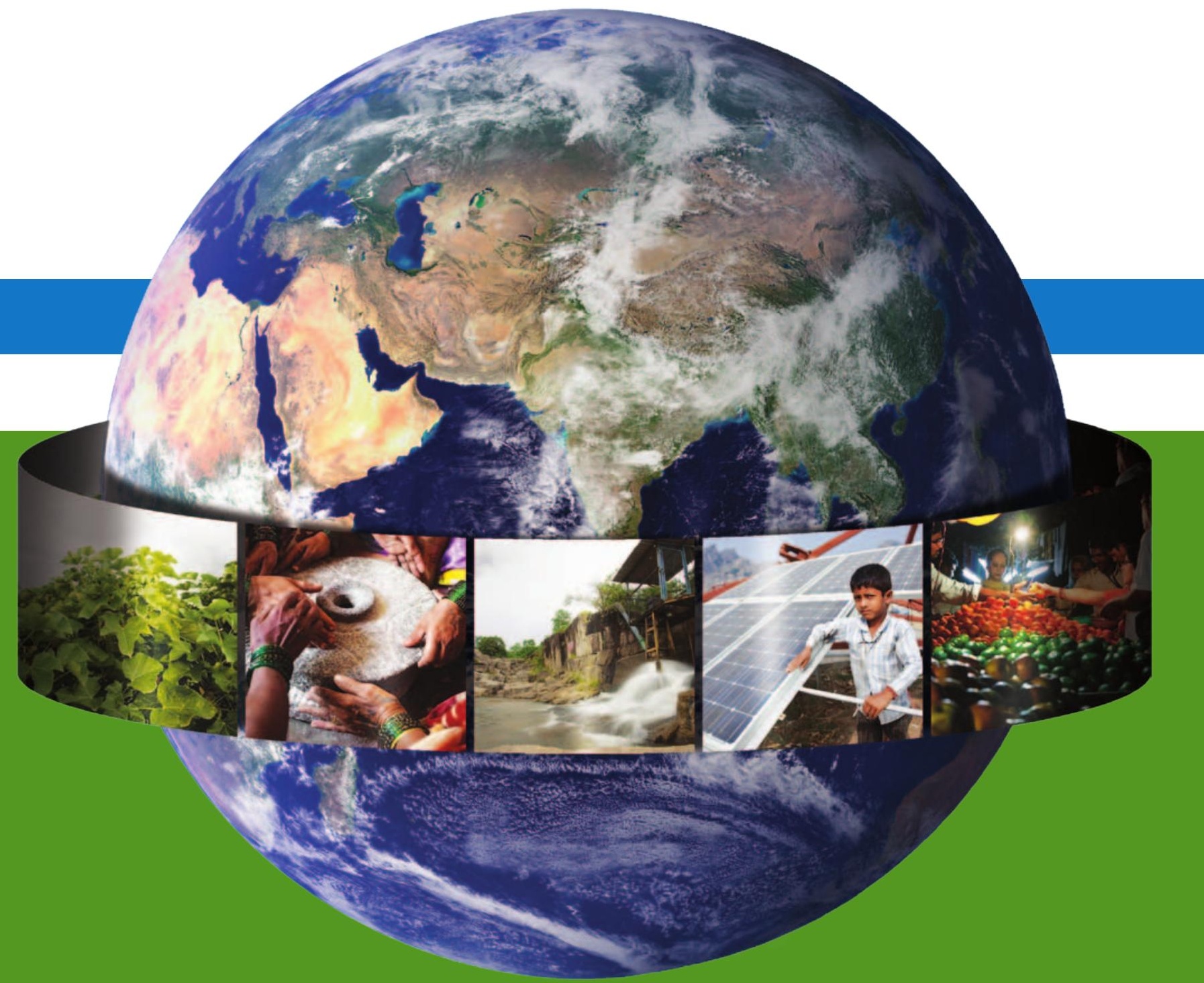

D. S. Arora (IRADe) | Sarah Busche (NREL) | Shannon Cowlin (NREL) |

Tobias Engelmeier (Bridge to India Pvt. Ltd.) | Hanna Jaritz (IRADe) |

Anelia Milbrandt (NREL) | Shannon Wang (REN21 Secretariat)

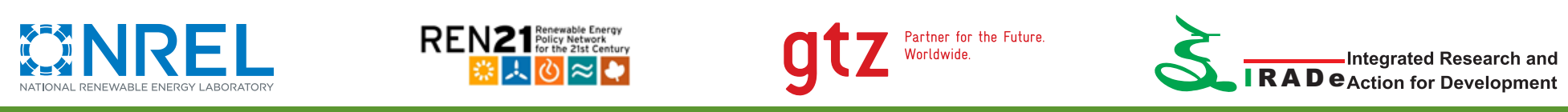




\section{NOTICE}

This report was prepared as an account of work sponsored by an agency of the United States government. Neither the United States government nor any agency thereof, nor any of their employees, makes any warranty, express or implied, or assumes any legal liability or responsibility for the accuracy, completeness, or usefulness of any information, apparatus, product, or process disclosed, or represents that its use would not infringe privately owned rights. Reference herein to any specific commercial product, process, or service by trade name, trademark, manufacturer, or otherwise does not necessarily constitute or imply its endorsement, recommendation, or favoring by the United States government or any agency thereof. The views and opinions of authors expressed herein do not necessarily state or reflect those of the United States government or any agency thereof.

Available electronically at http://www.osti.gov/bridge

Available for a processing fee to U.S. Department of Energy

and its contractors, in paper, from:

U.S. Department of Energy

Office of Scientific and Technical Information

P.0. Box 62

Oak Ridge, TN 37831-0062

phone: 865.576 .8401

fax: 865.576 .5728

email: mailto:reports@adonis.osti.gov

Available for sale to the public, in paper, from:

U.S. Department of Commerce

National Technical Information Service

5285 Port Royal Road

Springfield, VA 22161

phone: 800.553 .6847

fax: 703.605 .6900

email: orders@ntis.fedworld.gov

online ordering: http://www.ntis.gov/ordering.htm

This publication received minimal editorial review at NREL 


\section{Acknowledgments}

This report was produced in collaboration between National Renewable Energy Laboratory (NREL) in the United States, German Technical Cooperation (GTZ), Renewable Energy Policy Network for the $21^{\text {st }}$ Century (REN21) Secretariat in France, and Integrated Research and Action for Development (IRADe) in India. REN21 Secretariat has coordinated the process. The co-authors are extremely grateful for the masterful editorial work done by Paul Gilman and Mary Lukkonen. The co-authors thank Joshua Bauer for developing the graphics and designing the cover for this report. Finally, the co-authors would like to thank those who provided their feedback on earlier drafts of this report, in particular Nina Negic of Bridge to India Pvt. Ltd and Ron Benioff of NREL. Their suggestions and insights resulted in substantial improvements to the draft published here. Financing was provided by the German Federal Ministry for the Environment, Nature Conservation, and Nuclear Safety (BMU) and U.S. Department of Energy and Department of State.

\section{Authors}

D. S. Arora (IRADe)

Sarah Busche (NREL)

Shannon Cowlin (NREL)

Dr. Tobias Engelmeier (Bridge to India Pvt. Ltd.)

Hanna Jaritz (IRADe)

Anelia Milbrandt (NREL)

Shannon Wang (REN21 Secretariat)

Editing, Design, and Layout

Joshua Bauer (NREL)

Paul Gilman (NREL Consultant)

Mary Lukkonen (NREL)

\section{Contributors}

Jens Burgtorf (GTZ)

Nina Negic (Bridge to India Pvt. Ltd.)

Dr. Jyoti Parikh (IRADe)

Isabelle-Jasmin Roth (Bridge to India Pvt. Ltd.)

Virginia Sonntag-O'Brien (REN21 Secretariat) 


\section{List of Acronyms}

\begin{tabular}{|c|c|}
\hline $\mathrm{ADB}$ & Asian Development Bank \\
\hline APCTT & Asia Pacific Centre for the Transfer of Technology \\
\hline ARTI & Appropriate Rural Technology Institute \\
\hline $\mathrm{BEE}$ & Bureau of Energy Efficiency \\
\hline BGPG & Biogas Distributed/Grid Power Generation Program \\
\hline BHEL & Bharat Heavy Electricals Ltd \\
\hline BLY & Bachat Lamp Yojana \\
\hline BPL & below poverty line \\
\hline CDM & Clean Development Mechanism \\
\hline CEA & Central Electricity Authority \\
\hline CER & certified emission reduction credit \\
\hline CERC & Central Electricity Regulatory Commission \\
\hline CFA & Central Finance Assistance \\
\hline CFL & compact fluorescent lamp \\
\hline $\mathrm{ckm}$ & circuit kilometers \\
\hline CSP & concentrated solar power \\
\hline CSR & corporate social responsibility \\
\hline C-WET & Centre for Wind Energy Technology \\
\hline DANIDA & Danish International Development Agency \\
\hline DDG & Decentralized Distributed Generation \\
\hline DIREC & Delhi International Renewable Energy Conference \\
\hline DNES & Department of Non-conventional Energy Sources \\
\hline DNI & direct normal irradiance \\
\hline EBP & ethanol blended petrol \\
\hline EGTT & Expert Group on Technology Transfer \\
\hline EMD & earnest money deposit \\
\hline EPC & engineer-procure-construct \\
\hline $\mathrm{EU}$ & European Union \\
\hline GBI & Generation-based Incentive \\
\hline GDP & gross domestic product \\
\hline GEF & global environment facility \\
\hline GHG & greenhouse gas \\
\hline GHI & global horizontal irradiance \\
\hline GW & gigawatt (one billion watts) \\
\hline GWh & gigawatt-hour \\
\hline GWEC & Global Wind Energy Council \\
\hline ha & hectare \\
\hline IDBI & Industrial Development Bank of India \\
\hline IDFC & Infrastructure Development Finance Corporation \\
\hline IEA & International Energy Agency \\
\hline IEC & International Electrotechnical Commission \\
\hline IFC & International Finance Corporation \\
\hline IGCC & integrated gasification combined cycle \\
\hline INR & Indian Rupee \\
\hline IREC & International Renewable Energy Conference \\
\hline IREDA & India Renewable Energy Development Agency \\
\hline JNNSM & Jawaharlal Nehru National Solar Mission \\
\hline KfW & Kreditanstalt für Wiederaufbau (German Development Bank) \\
\hline
\end{tabular}




\begin{tabular}{|c|c|}
\hline $\mathrm{kW}$ & kilowatt \\
\hline $\mathrm{kWh}$ & kilowatt-hour \\
\hline LPG & liquefied petroleum gas \\
\hline MENA & Middle East and North Africa \\
\hline MFI & microfinance institutions \\
\hline MNRE & Ministry of New and Renewable Energy \\
\hline $\mathrm{MoP}$ & Ministry of Power \\
\hline MoRD & Ministry of Rural Development \\
\hline MPNG & Ministry of Petroleum and Natural Gas \\
\hline MSW & municipal solid waste \\
\hline MTOE & million tonnes of oil equivalent \\
\hline MVA & mega volt amperes \\
\hline MW & megawatt (one million watts) \\
\hline MWh & megawatt-hour \\
\hline NABARD & National Bank for Agriculture and Rural Development \\
\hline NAPCC & National Action Plan on Climate Change \\
\hline NASA & U.S. National Aeronautics and Space Administration \\
\hline NBMMP & National Biogas and Manure Management Program \\
\hline NEP & National Electricity Policy \\
\hline $\mathrm{NGO}$ & non-governmental organization \\
\hline NREL & National Renewable Energy Laboratory \\
\hline NTPC & National Thermal Power Corporation \\
\hline NVVN & NTPC Vidyut Vyapar Nigam Ltd \\
\hline PFC & Power Finance Corporation \\
\hline PPA & Power Purchase Agreement \\
\hline PV & photovoltaic \\
\hline R\&D & research and development \\
\hline $\mathrm{R} \& \mathrm{M}$ & renovation and modernization \\
\hline $\mathrm{RE}$ & renewable energy \\
\hline REC & Renewable Energy Certificates \\
\hline REDB & Rural Electricity Distribution Backbone \\
\hline REEEP & Renewable Energy and Energy Efficiency Partnership \\
\hline REN21 & Renewable Energy Policy Network for the 21 st Century \\
\hline RGGVY & Rajiv Gandhi Grameen Vidyutikaran Yojana \\
\hline RPO & Renewable Purchase Obligation \\
\hline RVE & Remote Village Electrification \\
\hline SEB & State Electricity Board \\
\hline SEC & Solar Energy Centre \\
\hline SEFI & Sustainable Energy Finance Initiative \\
\hline SERC & State Electricity Regulatory Commission \\
\hline SIPS & special incentive package scheme \\
\hline SME & small- and medium-sized enterprise \\
\hline SSE & Surface Meteorology and Solar Energy \\
\hline SWERA & Solar and Wind Energy Resource Assessment \\
\hline SWH & solar water heater \\
\hline TERI & The Energy and Resources Institute \\
\hline TWh & terawatt-hour \\
\hline UNDP & United Nations Development Programme \\
\hline UNEP & United Nations Environment Programme \\
\hline UNFCCC & United Nations Framework Convention on Climate Cha \\
\hline
\end{tabular}


USAID United States Agency for International Development

USD U.S. dollar

VESP Village Energy Security Programme

WIREC Washington International Renewable Energy Conference 


\section{Executive Summary}

India has great potential to accelerate the use of its endowed renewable resources to power its growing economy with a secure and affordable energy supply. The Government of India recognizes that development of local, renewable resources is critical to ensure that it is able to meet both its economic and environmental objectives, and it has promoted this development through policy action.

The Indian economy has experienced tremendous growth over the past several years. Energy, in all its forms, underpins both past and future growth. For the Indian economy to continue this trajectory, India needs to address its energy challenges, which cross all sectors and impact all citizens. Electricity - both in terms of quality and access - is a key challenge.

The quality of the current electricity supply is impeding India's economic growth. Issues such as voltage fluctuation, frequency variation, spikes, black-outs, brown-outs, and other disruptions impact industrial, commercial, and residential consumers. The addition of gridtied renewable power can help address these issues. The gap between the demand of customers connected to the grid and the available electricity supply reported by the Central Electricity Authority for 2009-2010 was almost 84 TWh, which is $10 \%$ of the total requirement. The peak demand deficit was more than $15 \mathrm{GW}$, corresponding to a shortage of $12.7 \%$. Closing this gap will be critical for India to achieve its growth targets, and renewable energy has the potential to improve energy security and reduce dependence on imported fuels and electricity while striving to meet those goals.

Much of India's population is not experiencing the benefits of economic growth. The Government of India sees the provision of electricity to all as critical to inclusive growth. It recognizes off-grid renewable energy as a practical, cost-effective alternative to an expansion of grid systems in remote areas of the country.

To be able to provide adequate electricity to its population, India needs to more than double its current installed capacity to over $300 \mathrm{GW}$ by 2017. Also, India's demand for oil in 2015 is expected to be $41 \%$ higher than in 2007 and almost $150 \%$ higher in 2030 - needed primarily to feed a growing transportation sector. The Indian government is aware of the size and importance of the challenges and that success will depend on structural changes in the industry and on new technologies and business models. Renewable energy is well positioned to play a critical role in addressing this growing energy demand for the following reasons:

- India has the natural resources. India has abundant, untapped renewable energy resources, including a large land mass that receives among the highest solar irradiation in the world, a long coastline and high wind velocities that provide ample opportunities for both land-based and offshore wind farms, significant annual production of biomass, and numerous rivers and waterways that have potential for hydropower.

- Renewable energy provides a buffer against energy security concerns. India's use of its indigenous renewable resources will reduce its dependence on imported, expensive fossil fuels.

- Renewable energy offers a hedge against fossil fuel price hikes and volatility. Increased competition for limited fossil resources is projected to push prices up, while increased deployment of renewable technologies pushes prices down in line with technology improvements and economies of scale. For example, oil prices in 
2030 are projected to be $46 \%$ higher than in 2010 while the investment costs for photovoltaic (PV) systems are expected to decrease to less than half of their 2007 levels over the same time period.

- Off-grid renewable power can meet demand in un-served rural areas. As a distributed and scalable resource, renewable energy technologies are well suited to meet the need for power in remote areas that lack grid and road infrastructure.

- Renewable energy can be supplied to both urban and rural poor. Renewable energy technologies offer the possibility of providing electricity services to the energy poor while addressing India's greenhouse gas (GHG) concerns and goals.

- Renewable energy can support attainment of India' climate change goals. Through its National Action Plan on Climate Change (NAPCC) and through its recently announced carbon intensity goal, India has made a commitment to addressing its carbon emissions.

- India aims to be a global leader in renewable energy. India's intention to play a leadership role in the emergent global green economy is driving investment in renewable energy technologies. Recognizing the magnitude of the potential demand for renewable energy, India is attracting significant investment in renewable energy.

Renewable energy represents an area of tremendous opportunity for India, and this report discusses the ways in which India has already supported the growth of renewable energy technologies, the impact this has had on utilization of various technologies, and the enormous remaining potential. The report is meant for those who want to better understand the role renewable energy has had to date in India, the policies that have been implemented to support renewable energy deployment, and the potential for renewable energy technologies to expand their contribution to India's growth in a way that is consistent with India's developmental and environmental goals.

Chapter 1, Indian Energy and Climate Change Status, gives a brief overview of the climate change policies that influence energy use in India, gives an overview of India's energy sector, and discusses the specific conditions and challenges of the Indian power market.

India currently emits approximately $4 \%$ of global GHG emissions. However, its per capita emissions are only one-quarter of the global average and less than one-tenth of those of most developed nations. India has committed to reducing the emissions intensity of its economy to $20 \%-25 \%$ below 2005 levels by 2020 and has pledged that per capita GHG emissions will not exceed those of industrialized nations.

There are two primary climate-focused instruments that are influencing deployment of renewable energy technologies in India. The first is NAPCC, which was released in 2008 with the aim of promoting development goals while addressing GHG mitigation and climate change adaptation. NAPCC suggests that up to $15 \%$ of India's energy could come from renewable sources by 2020 . The NAPCC includes eight focused missions, one of which is dedicated to solar energy (the others concern energy efficiency, water, sustainable habitat, and related topics). In addition, the Clean Development Mechanism (CDM) of the Kyoto Protocol is supporting development of renewable energy projects in India. As of September 2010, there were over 500 registered CDM projects in India, and these are dominated by renewable energy projects. 
Chapter 2, The Status of Renewable Energy in India, describes the role of renewable energy in the overall energy sector in India and more specifically in industrial end use, transportation, and electricity generation; it presents the growth trends of renewable energy in India and the institutional and policy environment that is currently supporting continued deployment of renewable energy technologies.

The Government of India's Ministry of New and Renewable Energy (MNRE) reports that, as of June 2010, India has over $17.5 \mathrm{GW}$ of installed renewable energy capacity, which is approximately $10 \%$ of India's total installed capacity. Wind represents $11.8 \mathrm{GW}$, small hydro represents $2.8 \mathrm{GW}$, and the majority of the remainder is from biomass installations. PV installations have reached $15 \mathrm{MW}$ of cumulative capacity installation for both on- and offgrid applications. In the current, Eleventh Five-Year Plan (Eleventh Plan; 2007-2012), the Government of India targets capacity additions of $15 \mathrm{GW}$ of renewable energy, which, if achieved, would bring the cumulative installed capacity to over $25 \mathrm{GW}$ in 2012.

In 1992, the Government of India established MNRE, the world's first ministry committed to renewable energy. MNRE is dedicated to expanding contributions of renewable energy in all of India's end-use sectors and undertakes policy and planning activities to that end. MNRE also supervises national-level renewable energy institutes such as the Solar Energy Centre and the Centre for Wind Energy Technology. The Indian Renewable Energy Development Agency (IREDA) provides financial support and innovative financing for renewable energy and energy efficiency projects with funds from the Indian government and multilateral lending agencies. IREDA also administers the central government's renewable energy incentive programs. Other government institutions with direct responsibilities that extend into renewable energy include several units under the Ministry of Power, the Planning Commission, and the Prime Minister's Council on Climate Change.

The Government of India has enacted several policies to support the expansion of renewable energy. Those that apply to more than one renewable technology include the following (technology-specific policies are discussed in the relevant chapters):

- Electricity Act 2003: Mandates that each State Electricity Regulatory Commission (SERC) establish minimum renewable power purchases; allows for the Central Electricity Regulatory Commission (CERC) to set a preferential tariff for electricity generated from renewable energy technologies; provides open access of the transmission and distribution system to licensed renewable power generators.

- National Electricity Policy 2005: Allows SERCs to establish preferential tariffs for electricity generated from renewable sources.

- National Tariff Policy 2006: Mandates that each SERC specify a renewable purchase obligation (RPO) with distribution companies in a time-bound manner with purchases to be made through a competitive bidding process.

- Rajiv Gandhi Grameen Vidyutikaran Yojana (RGGVY) 2005: Supports extension of electricity to all rural and below poverty line households through a $90 \%$ subsidy of capital equipment costs for renewable and non-renewable energy systems.

- Eleventh Plan 2007-2012: Establishes a target that 10\% of power generating capacity shall be from renewable sources by 2012 (a goal that has already been reached); supports phasing out of investment-related subsidies in favor of performance-measured incentives. 
As of April 2010, 18 states had established RPOs or had draft regulations under consideration with RPO requirements ranging from $1 \%$ to $15 \%$ of total electricity generation. In January 2010, CERC announced the terms of a tradable Renewable Energy Certificate (REC) program. Under this program, generators choose between selling the renewable electricity generated at a preferential tariff and selling the electricity generated separately from the environmental benefits. The environmental attributes can be exchanged in the form of RECs, which will be issued by a central agency set up for administration of this program. RPOs are not yet enforced.

Chapter 3, Wind Power, describes India's wind potential and development to date, policies supporting the growth of wind energy in India, and key opportunities as India's wind sector continues to expand.

MNRE's official estimate of India's on-shore wind capacity potential is over $48 \mathrm{GW}$. Industry associations assert that taking into account hub heights greater than $50 \mathrm{~m}$ and improving conversion efficiencies from technology advancements and aggressive policy action, the potential is much greater with ranges between 65 and $242 \mathrm{GW}$. India ranked fifth globally in total installed wind capacity in 2009, and as of March 2010, India had realized almost $12 \mathrm{GW}$ of installed wind capacity. In addition to the sizable on-shore potential identified for India, the long coastline and prevailing wind patterns suggest substantial potential for offshore capacity, though no systematic assessment of offshore potential has yet been done.

The efficiency of India's existing wind plants is somewhat lower than in many of the other countries leading in wind. Technology and market factors combined with a shift from capacity-based incentives to generation-based incentives are expected to increase the efficiency of new wind plants.

Chapter 4, Solar Power, discusses the status of three solar technologies in India: solar PV, concentrating solar power (CSP), and solar water heating (SWH).

In June 2010, cumulative installed capacity of solar PV in India reached 15.2 MW, of which 12.3 MW was grid-tied (less than $0.1 \%$ of grid-tied renewable energy capacity in India) and $2.9 \mathrm{MW}$ was off-grid ( $0.7 \%$ of off-grid renewable energy capacity in India). The recent Jawaharlal Nehru National Solar Mission (JNNSM) aims to dramatically increase installed PV through attractive feed-in tariffs and a clear application and administration process. Phase 1 of JNNSM targets additions of 500 MW of grid-tied and 200 MW of off-grid PV capacity by 2013. PV installations of $365 \mathrm{MW}$ are approved for the state of Gujarat and $36 \mathrm{MW}$ for the state of Rajasthan. By the end of Phase 3 in 2022, India plans to have 10,000 MW of gridtied and 2,000 MW of off-grid PV.

JNNSM reaches beyond installed capacity to also target the growth of India's indigenous PV industry, which has historically supplied the export market. Annual Indian module production is expected to exceed $2,500 \mathrm{MW}$ by 2015 , and JNNSM targets an annual production of $4,000-5,000 \mathrm{MW}$ by 2022 .

There are currently no CSP plants in India. However, JNNSM targets the introduction and substantial additions of CSP. Estimates across India show large areas with sufficient radiation for the development of CSP plants, and one analysis foresees the technical potential for CSP generation in India at almost 11,000 TWh per year. JNNSM envisions $500 \mathrm{MW}$ of CSP by 
2013 and $10,000 \mathrm{MW}$ by 2022 . India is on track to meet the first goal-currently there are $351 \mathrm{MW}$ of approved CSP projects in Gujarat and another $30 \mathrm{MW}$ in Rajasthan.

SWH technology presents an opportunity to avoid using electricity or liquefied petroleum gas for heating water in India. It has applications in the residential, commercial, and industrial sectors. India has approximately 3.5 million $\mathrm{m}^{2}$ of installed SWH collector area out of an estimated potential of 40 million $\mathrm{m}^{2}$. Several programs are in place to accelerate deployment of SWH, including the provision of low-interest loans and incorporation of SWH into the building code.

Chapter 5, Small Hydro, presents the status of small hydropower in India, defined by the Government of India as hydropower plants up to $25 \mathrm{MW}$, including the identified potential and contribution to India's rural electrification efforts.

MNRE has estimated India's small hydro potential at more than 15,000 MW and is constantly revising this number upwards as new sites are identified; more than $40 \%$ of this potential has been identified in four northern, mountainous states. Capital incentives are in place to support installation of new small hydropower plants, as well as to renovate and modernize existing plants. In addition to direct subsidies at the state and national level, small hydro plants may also qualify for low-interest loans and income tax exemptions. CERC also offers preferential tariffs for small hydro plants with the tariff amount and time period varied depending on project size and location.

High capacity factors have been observed at small hydro plants in remote, mountainous regions of India, and small hydro has the lowest levelized costs of energy of any renewable technology in India. These factors have contributed to small hydro's importance in India's rural electrification efforts, with both federal and state programs supporting small hydro as a means of supplying electricity to villages where providing access to the central grid is challenging.

Chapter 6, Bioenergy, covers bioenergy in India and discusses the status and potential for biogas, solid biomass, and biofuels.

Traditional biomass, such as wood and cow dung, have historically played an important part in India's energy supply, and they still supply cooking energy to almost all of India's rural population. By utilizing organic waste and agricultural output, India can incorporate modern bioenergy as a substantial part into its future energy mix.

There are approximately 4 million installed household biogas plants in India with almost 4,000 additional units supplying household clusters or villages; cattle manure is the primary feedstock for these household plants. MNRE estimates that available cattle manure could support approximately 12 million household biogas plants. Larger-scale biogas facilities use industrial wastewater to generate electricity, and the 48 such plants in India have an aggregate installed capacity of $70 \mathrm{MW}$. MNRE estimates the total capacity potential for industrial biogas to be $1.3 \mathrm{GW}$. National and state programs support expansion of biogas through technical capacity building, financial incentives, and demonstration projects, with additional deployment supported through the CDM.

Solid biomass is used in India either in direct combustion or gasification to generate power or for cogeneration of power and heat. MNRE estimates that surplus biomass could support 25 MW of installed electricity-generating capacity and that cogeneration capabilities added to 
existing industries requiring process heat could add $15 \mathrm{GW}$ more electricity-generating capacity to the grid. Policies in place to support biomass power generation include capital and interest subsidies and tax exemptions, and CERC and several states offer a preferential tariff for electricity generated from biomass power or cogeneration plants.

Liquid biofuels, ethanol and biodiesel, are used to substitute petroleum-derived transportation fuels. Ethanol in India is largely produced by the fermentation of molasses, a by-product of the sugar industry, and from biodiesel produced from non-edible oilseeds. India is conducting research in the area of cellulosic biomass conversion for ethanol production. Making use of one-third of the 189 million tonnes of surplus biomass could yield approximately 19 billion liters of gasoline equivalent each year, the equivalent of India's entire gasoline consumption. Support for liquid biofuels comes in the form of subsidized loans for ethanol production facilities, tax exemptions for biodiesel, financial incentives promoting the cultivation of Jatropha and other non-edible oil seeds, and research and development programs.

\section{Chapter 7, Decentralized Energy, presents the role of renewable energy in India's decentralized energy systems including rural electrification and captive power for industry.}

According to the International Energy Agency, in 2008, more than 400 million Indians did not have access to electricity, with electrification rates of $93.1 \%$ and $52.5 \%$ in urban and rural areas, respectively. There are several programs at the national level to promote electrification of remote villages and below poverty line households. Renewable technologies deployed to this end include family biogas plants, solar street lights, solar lanterns, solar PV systems, and micro-hydro plants. The Indian government has initiated several programs, policies, and acts that focus on the development of rural energy, economy, and electrification to improve rural livelihood with the help of renewable energy. Successful business models have been designed to address shortcomings of global electrification efforts to increase sustainability and user satisfaction. Among these is a model for village electrification using biomass gasifiers where an energy service company, entrepreneur, or other actor provides system maintenance and operations and collects feedstock for use from households and businesses. Finding viable business solutions to supplying India's non-electrified households is perhaps the greatest single challenge and opportunity of the renewable energy market.

In addition to using renewable energy to provide electricity to poor and remote citizens, renewable technologies are being used by industries that generate electricity at their facilities to supplement grid power and to use when power from the grid is unavailable. At the end of March 2008, the total renewable installed capacity for captive power plants greater than 1 MW was $305 \mathrm{MW}$, almost all of which was wind capacity. In addition to wind, solar thermal plants show good potential for captive power supply by integrating with the steam turbines already in place at cogeneration facilities. Industries can also deploy solar PV systems and use biodiesel in onsite generators to help power their operations.

Chapter 8, Technology Transfer, discusses the relevance of international renewable energy technology to India as well as roles of the public and private sectors.

Technology transfer is considered an important element of India's low-carbon growth strategy. Though India is a strong international competitor in areas like wind and PV, a domestic base for other renewable technologies is lacking, and much of the research and innovation is happening outside the country. India presents opportunities across the value chain including research and development, component manufacturing, investment, project development, power production, service and maintenance, and training and education. The 
private sector requires a stable investment environment and cost competitiveness to capitalize on these opportunities. Actions of the Indian government and the international community can contribute to the conditions necessary for accelerated entry of international actors into India's renewable energy sector.

\section{Chapter 9, Financing Renewable Energy in India, presents the current renewable energy} investment climate in India.

In 2009, India ranked eighth globally for clean energy investments and is ranked as the fourth most attractive country for renewable energy investment, only behind the United States, China, and Germany. The majority of renewable energy financing in India has been asset finance (for renewable energy generation projects), accounting for $70 \%$ in 2009 after a drop from levels in previous years. The majority of this went to the wind sector, though with the release of JNNSM and the National Biofuels Policy, greater shares may go to the solar and bioenergy sectors in the future. International and bilateral finance institutions are involved in clean energy financing in India, providing private sector financing, technology financing, and more specialized support. Renewable energy in India is also receiving financial support through the CDM. India accounts for more than $20 \%$ of registered projects under CDM, and the majority of these are renewable energy projects. The Government of India and nongovernmental organizations have historically been the largest funders of clean energy in India, and they still are active in their support. IREDA administers the federal government's revolving renewable energy fund and administers much of the international funding as well. The balance of renewable energy finance in India is made up of various sources including venture capital and commercial financing.

Chapter 10, Enabling Environment, concludes the paper with a discussion of factors for continued renewable energy growth in India and elsewhere and the role of the International Renewable Energy Conference series.

The International Renewable Energy Conference process seeks to bring together renewable energy stakeholders from across the world to share best practices for renewable energy policy, financing, and human capacity development. The Delhi International Renewable Energy Conference (DIREC) will build on the progress of the previous three in this series of ministerial-level conferences and will focus on scaling up and mainstreaming renewable energy in the context of energy security, climate change, and economic development, all of which are important themes to the Government of India. The conference will include discussions on key factors that are critical to widespread deployment of renewable energy technologies: the policy landscape needed to affect a substantial scale-up of renewable energy globally, the innovative financing that may also facilitate accelerated renewable development, and technology development and cost trends that are expected in the coming years, some of which are also discussed in this chapter.

India seeks to become an international leader in renewable energy to support its goals of energy access for the sectors of the population currently un-served; fuel its economy, which is returning to an annual growth of nearly $9 \%$ as experienced before the recent downturn; enhance energy security against price and supply disruptions; and demonstrate leadership on the global stage in mitigating GHG emissions. JNNSM is India's most ambitious renewable energy initiative. If its goal of achieving grid parity of solar power by 2022 can be achieved, this energy source can quickly become one of the pillars of India's energy mix. India has substantial on-shore wind generating capacity, with additional potential for development. Preliminary investigation of India's off-shore wind speeds suggests off-shore wind also has 
strong potential for contributing to India's power generation mix. Small hydro remains a costeffective means for providing electricity in many areas of India, including the remote Himalayas where connection to the central grid is impractical. The potential for biopower generation from waste materials is far from being exhausted, and these plants could add much-needed capacity to the grid. Indigenous biofuel production, including from emerging technologies such as cellulosic ethanol and algal biodiesel, could aid India's growth without developing an overreliance on imported oil. Maximum utilization of India's resources will require several elements acting in concert: a supportive policy environment, ample financing opportunities, and technology advancement. India has demonstrated commitment and leadership in tacking the challenges and is poised to accelerate this transition to a robust renewable energy future. 


\section{Table of Contents}

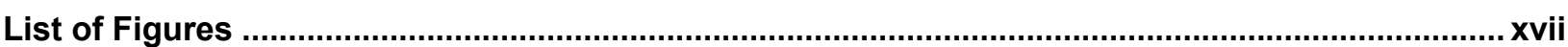

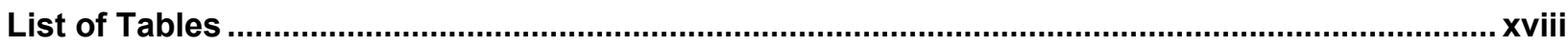

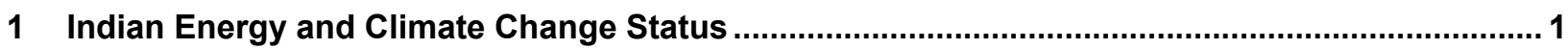

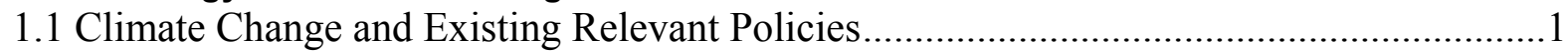

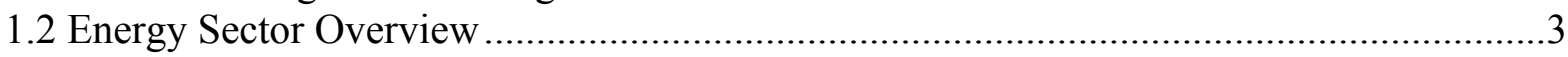

1.3 The Power Market in India and the Role of Renewable Energy .......................................

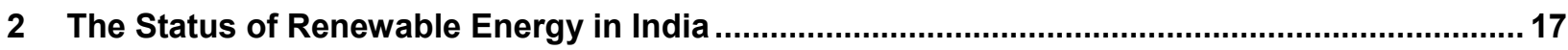

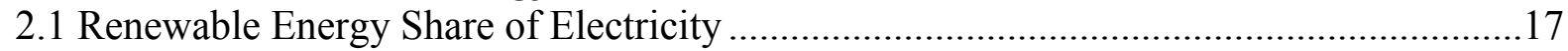

2.2 Renewable Energy Application in Industrial Use and Transportation ...........................19

2.3 National Renewable Energy Institutions and Policies ..................................................20

2.4 Governance and Institutional Arrangement of Renewable Energy ................................23

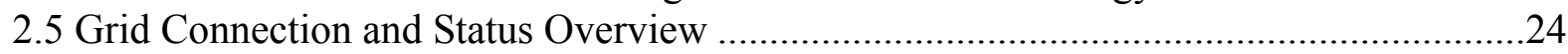

2.6 Renewable Purchase Obligations and Renewable Energy Credits ................................25

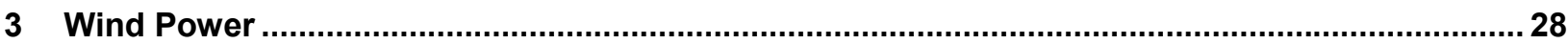

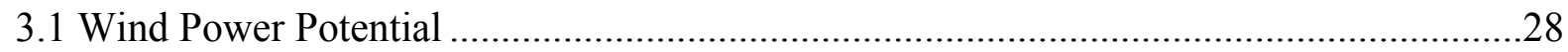

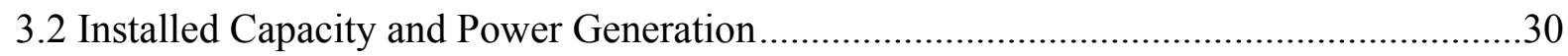

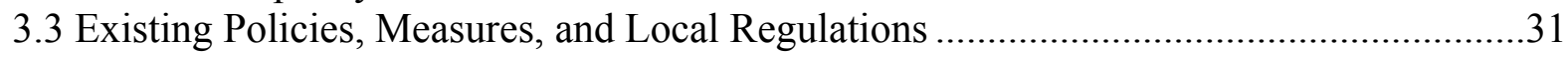

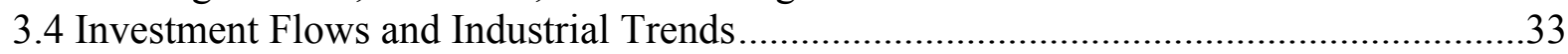

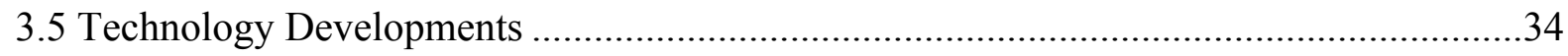

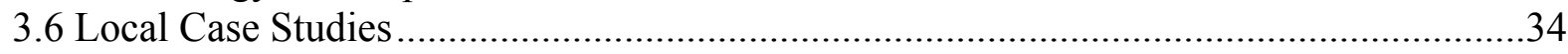

3.7 Success Stories from the International Community and Potential Opportunities for

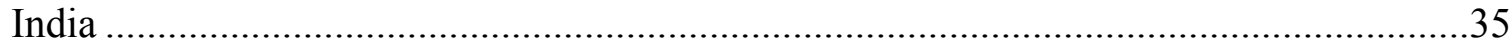

4 Solar Power

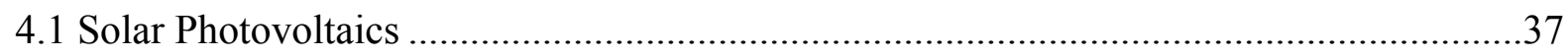

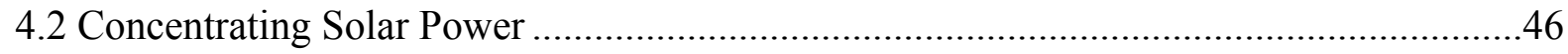

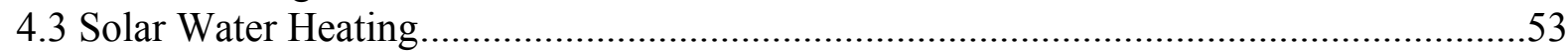

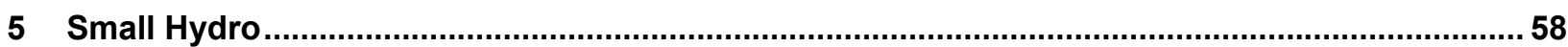

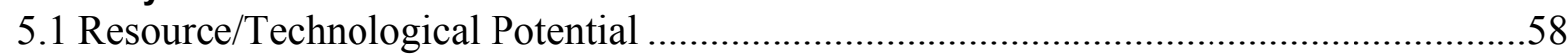

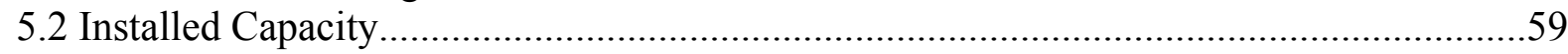

5.3 Existing Policies, Measures, and Local Regulations ..................................................60

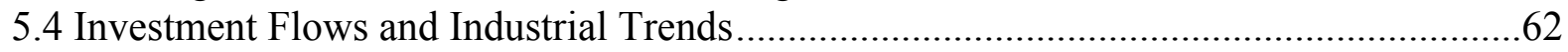

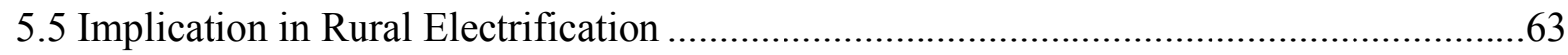

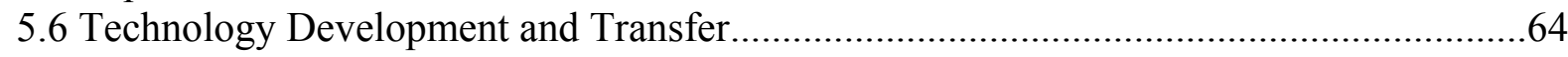

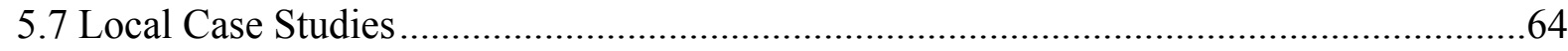

5.8 Success Stories from the International Community and Potential Opportunities for

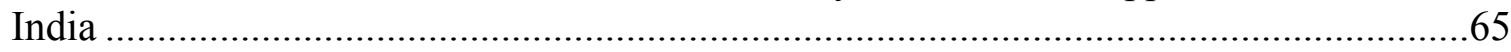

6 Bioenergy

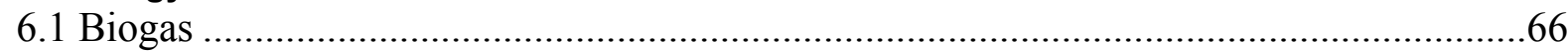

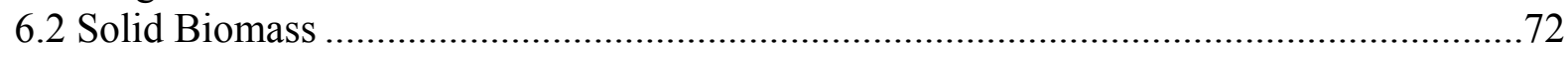

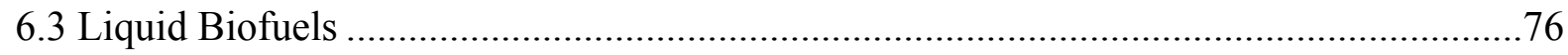

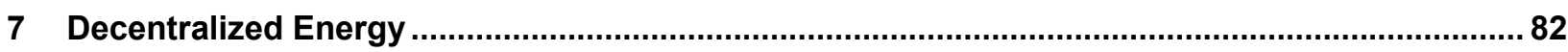

7.1 Renewable Energy_-Implication in Rural Electrification.........................................82

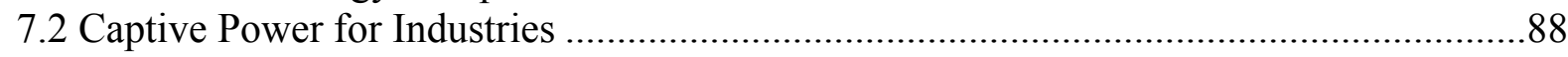




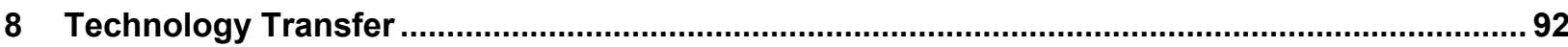

8.1 The Role of the Private and Public Sector in Technology Transfer ................................92

8.2 Technology Transfer Through the Private Sector: Opportunities and Barriers .................93

8.3 The Role of the Public Sector in Improving Technology Transfer .................................96

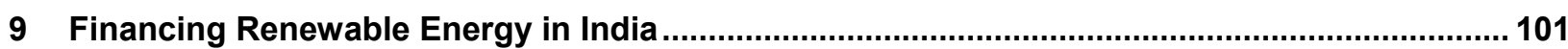

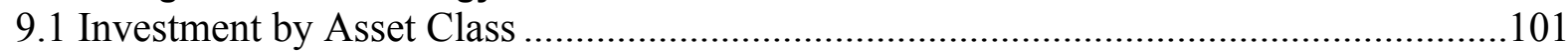

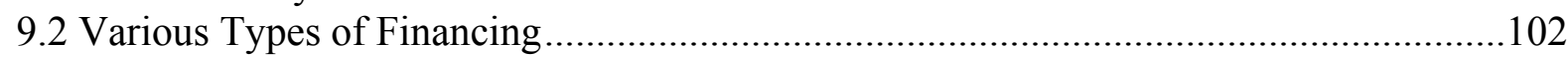

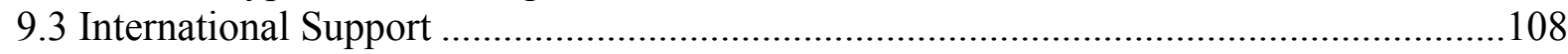

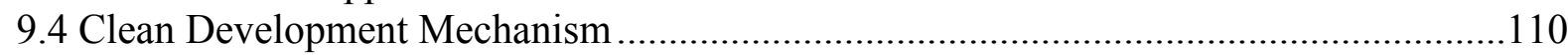

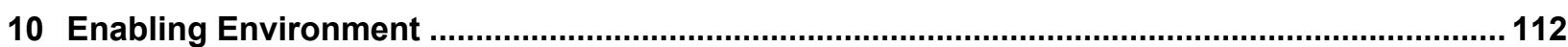

10.1 History of the International Renewable Energy Conference Process ...........................112

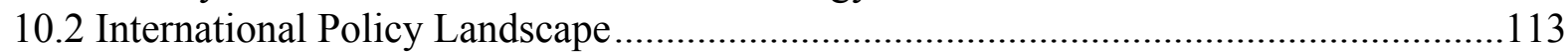

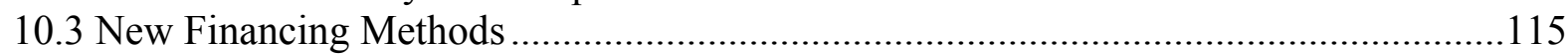

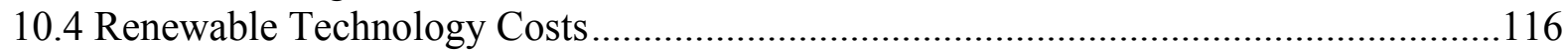

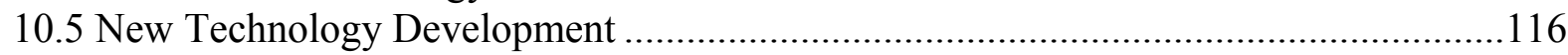

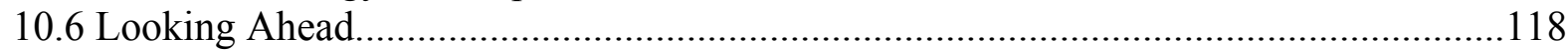




\section{List of Figures}

Figure 1-1. Scenarios for the development of necessary peak load capacities ........................... 5

Figure 1-2. Worldwide consumption of primary sources of energy by country (2008) ............... 6

Figure 1-3. Development of commercial energy consumption in India .................................... 6

Figure 1-4. Percentage share of commercial energy sources in India (2004)............................ 7

Figure 1-5. Per capita annual electricity consumption in India ............................................... 9

Figure 1-6. India electricity consumption sector-wise (utilities \& non-utilities, 2008-2009)..... 10

Figure 1-7. Installed capacities for power generation in India according to energy source

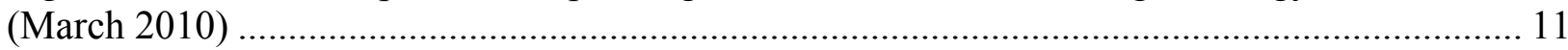

Figure 1-8. Percentage of public and private sector power generation capacity by energy

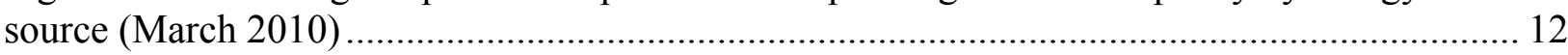

Figure 1-9. Development of installed electrical capacities of utilities and non-utilities in India 13 Figure 1-10. Forecast growth in capacity by the end of the Eleventh Plan according to sector

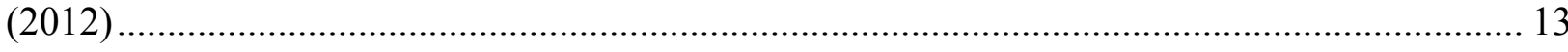

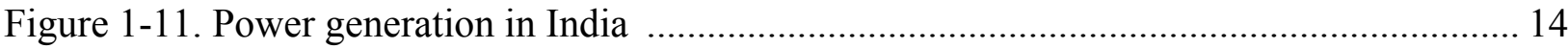

Figure 2-1. Route for sale of renewable energy generation................................................ 27

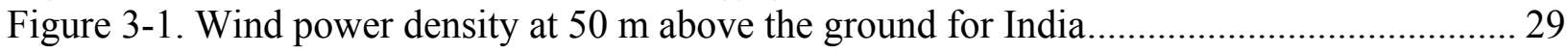

Figure 3-2. Growth of installed wind power capacity in India .......................................... 30

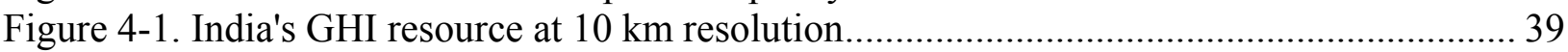

Figure 4-2. India's DNI resource at $10 \mathrm{~km}$ resolution ....................................................... 48

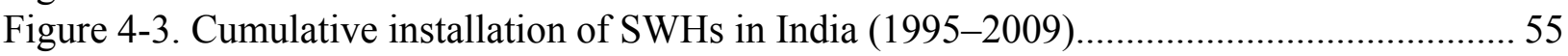

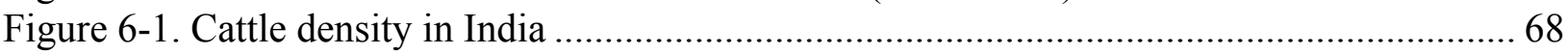

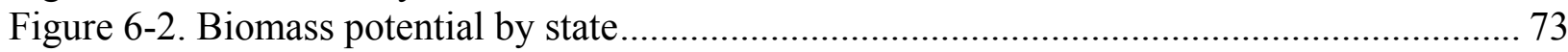

Figure 6-3. Potential area for Jatropha cultivation by state .................................................. 78

Figure 7-1. Rural energy through biomass gasifier: Business model ...................................... 87

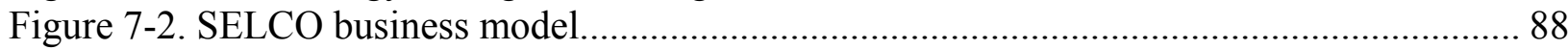

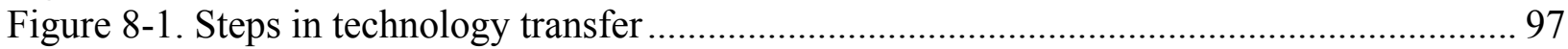

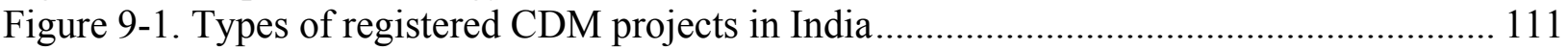




\section{List of Tables}

Table 2-1. Development of Grid-connected Renewable Power in India (in MW) ..................... 18

Table 2-2. Power Generation Costs in India by Energy Source (2008)..................................... 19

Table 2-3. Actors in the Indian Power Market Along the Value-creation Chain ......................... 24

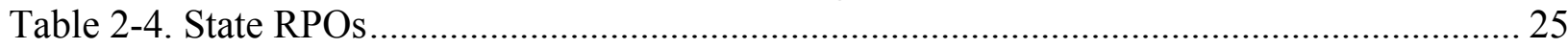

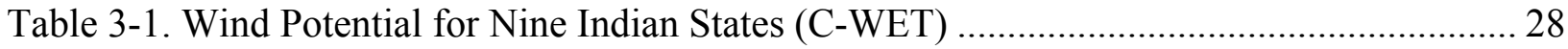

Table 3-2. Wind Capacity Additions by State ....................................................................... 31

Table 4-1. India: Estimated Land Area Suitable for CSP Development and Generation

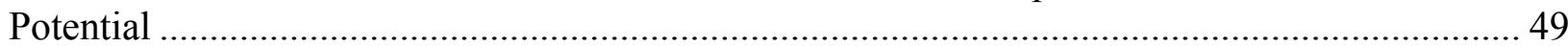

Table 4-2. Approved CSP Projects in Gujarat and Rajasthan ................................................ 50

Table 4-3. SWH Existing Capacity, Top 10 Countries (2008) ................................................... 54

Table 4-4. Estimated Breakdown: Functional SWH Installation Through December 31, 2009 .. 56

Table 5-1. Small Hydro Potential by Indian State, Number of Sites, Installed Capacity, Installed Projects, and Capacity Under Development as of December 31, 2009 ....................... 59

Table 5-2. MNRE Support for New Small Hydro Projects Implemented by the State ............... 61

Table 5-3. MNRE Support for New Small Hydro Projects Implemented by the Private Sector

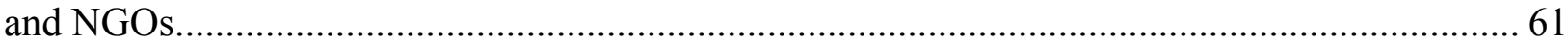

Table 5-4. MNRE Scheme to Renovate and Modernize Existing Projects .............................. 61

Table 5-5. CERC-Small Hydro Preferential Tariffs for FY 2009-2010 _................................ 62

Table 7-1. All India Captive Power Plants of Industry (1 MW and Above) .............................. 89

Table 7-2. Wind Power Plant Installed Capacity and Generation at Captive Power Facilities .... 90

Table 7-3. Renewable Energy Installed Capacity and Generation by Industry ......................... 90

Table 9-1. New Financial Investment in India by Sector and Asset Class, 2009 ..................... 102

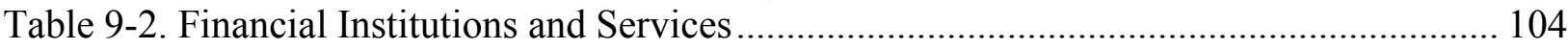

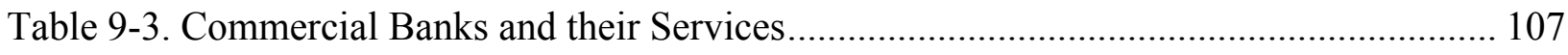

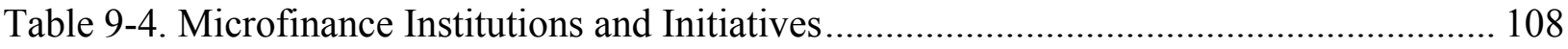

Table 9-5. Bilateral and Multilateral Institutions and Services ............................................ 110 


\section{Indian Energy and Climate Change Status}

\section{Chapter Overview}

In 2008 , India accounted for $17.7 \%$ of the world population but was the fifth-largest consumer of energy, accounting for 3.8\% of global consumption. India's total commercial energy supply is dominated by coal and largely-imported oil with renewable energy resources contributing less than $1 \%$ (this does not include hydro $>25 \mathrm{MW}$ ). Coal also dominates the power generation mix, though renewable resources now account for approximately $10 \%$ of installed capacity. The current power-generating capacity is insufficient to meet current demand, and in 2009-2010, India experienced a generation deficit of approximately $10 \%$ (84 $\mathrm{TWh}$ ) and a corresponding peak load deficit of $12.7 \%$ (over $15 \mathrm{GW}$ ). India's frequent electricity shortages are estimated to have cost the Indian economy $6 \%$ of gross domestic product (GDP) in financial year 2007-2008. To power the economic growth currently being targeted, it is estimated that India will need to more than double its installed generating capacity to over $300 \mathrm{GW}$ by 2017 . In recent years, control over generating facilities has shifted from being dominantly controlled by the states to the federal government and private entities, including those who have set up captive power plants to power their industrial facilities. The private sector is dominant in renewable energy generation.

India's energy future will not just be shaped by the central grid and large-scale generating facilities fueling industrial growth but also by the goal of increasing the well-being of India's poor populations by providing electricity access to the approximately 400 million citizens without. The Government of India recognizes that development of local, renewable resources is critical to ensure that India is able to meet social, economic, and environmental objectives and has supported the development of renewable energy through several policy actions.

Energy planning in India is taking place in the context of climate change negotiations. India participates in the international climate negotiation process, has pledged to reduce its economy's greenhouse gas (GHG) intensity, and has pledged that its per capita emissions will not exceed those of developed nations. India has implemented a National Action Plan on Climate Change (NAPCC), which suggested that $15 \%$ of energy could come from renewable sources by 2020. The NAPCC has eight National Missions, one of which is focused specifically on renewable energy: The Jawaharlal Nehru National Solar Mission (JNNSM). India is an active participant of the Clean Development Mechanism (CDM) with the second largest number of projects registered among all countries participating, the majority of which are renewable energy projects.

\subsection{Climate Change and Existing Relevant Policies}

While India's first priority is to ensure a sufficient and stable supply of power by expanding fossil-fuel-based generation and installing new large hydro and nuclear power plants, the following considerations contribute to the case for developing renewable energy projects:

- The use of India's indigenous renewable resources will reduce India's dependence on imports of fossil fuels.

- Increased competition for limited fossil resources is projected to push prices up, while increased deployment of renewable technologies will push prices down in line with technology improvements and economies of scale. For example, oil 
prices in 2030 are projected to be $46 \%$ higher than in $2010^{1}$ while the investment costs for photovoltaic (PV) systems are expected to decrease to less than half of their 2007 levels over the same time period. ${ }^{2}$

- Renewable energy technologies are well-suited to meet India's need for power in remote areas that lack grid and road infrastructure due to the distributed nature of resources and the scalability of system design.

- India's intention to play a leadership role in the emergent global renewable energy economy is driving investment in renewable energy technologies.

- Renewable energy technologies offer the possibility of providing electricity services to the energy poor while addressing India's GHG concerns and goals.

While no official goal for stabilizing GHG emissions has been set, India has declared that per capita GHG emissions will not be permitted to exceed those of industrialized countries ${ }^{3}$ and has committed to reducing the emission intensity of its GDP by $20 \%-25 \%$ by 2020 from the 2005 level. ${ }^{4}$ The main ways of achieving this reduction are improving fossil fuel power generation through new technologies such as supercritical and ultra-supercritical coal plants and integrated gasification combined cycle (IGCC), reducing aggregate technical and commercial losses, improving public transport, and increasing end-user efficiency. Given the shortage and cost of fossil resources, these measures also make sense from a purely economic perspective. Reducing emissions beyond the capability of these measures will require India to shift to low-carbon technologies that have a much higher initial capital commitment and much lower rate of return. ${ }^{5}$

Currently, India's emissions are around 1 ton of $\mathrm{CO}_{2}$ per person per year. The global per capita average is 4.2 tons with most industrialized countries emitting 10-20 tons per person per year. Nevertheless, because of its large population, India already contributes around $4 \%$ to global emissions. ${ }^{6}$

\subsubsection{National Action Plan on Climate Change}

In June 2008, India released the NAPCC to promote development goals while addressing climate change mitigation and adaptation.?

\footnotetext{
${ }^{1}$ European Commission. "World Energy, Technology and Climate Policy Outlook." http://ec.europa.eu/research/energy/pdf/weto final report.pdf. Accessed October 2010.

${ }^{2}$ IEA. "World Energy Outlook 2008." http://www.worldenergyoutlook.org/docs/weo2008/WEO2008.pdf. Accessed October 2010.

${ }^{3}$ Public Diplomacy Division, Ministry of External Affairs. "The Road to Copenhagen: India's Position on Climate Change Issues.” Government of India. http://pmindia.nic.in/Climate\%20Change 16.03.09.pdf. Accessed May 2010.

${ }^{4}$ Ministry of Environment and Forests. Annual Report 2009-2010. p. 271. http://moef.gov.in/report/report.html. Accessed August 2010.

${ }^{5}$ See the recent study: Center for Science and Environment (CSE). "Challenge of the New Balance." April 2010. IRADe is currently performing an even more comprehensive study on India's low carbon growth options for the National Planning Commission of India.

${ }^{6}$ Ministry of Environment and Forests. Annual Report 2009-2010. p. 268. http://moef.gov.in/report/report.html. Accessed August 2010.

${ }^{7}$ Press Information Bureau, Government of India. "Ministry of Environment and Forests." http://pib.nic.in/release/rel_print_page1.asp?relid=44098. Accessed September 2010. For further information, see: http://pmindia.nic.in/Pg01-52.pdf. Accessed September 2010.
} 
One of the eight National Missions outlined in the NAPCC, JNNSM (described in Chapter 4), specifically focuses on solar energy and its role to minimize future emissions while expanding development opportunities throughout the country.

The other seven National Missions are the National Mission for Enhanced Energy Efficiency, the National Mission on Sustainable Habitat, the National Water Mission, the National Mission for Sustaining the Himalayan Ecosystem, the National Mission for a Green India, the National Mission for Sustainable Agriculture, and the National Mission on Strategic Knowledge for Climate Change.

The NAPCC suggested that as much as $15 \%$ of India's energy could come from renewable sources by 2020 .

\subsubsection{Clean Development Mechanism}

Under the Kyoto Protocol, the CDM allows for projects in developing countries that result in a reduction of GHG emissions to earn certified emission reduction credits (CERs). ${ }^{8}$ CERs are carbon credits issued under the CDM that each represent 1 ton of carbon dioxide equivalent. CERs can be traded or sold and eventually used by industrialized countries that have ratified the Kyoto Protocol to meet parts of their emissions reduction targets. To qualify to receive CERs, the project must first be approved by the Designated National Authorities of the project host country, and then a public registration and issuance process with the UNFCCC must be completed. The additional funds generated through the sale or trade of CERs can improve the financial viability of clean energy projects.

Although there has been some criticism of the CDM process (e.g., the additional financial and technical criteria necessary or the long and costly project certification process), India has been at the forefront of receiving CDM benefits. As of January 2010, 1,551 Indian projects have been granted host country approvals. The projects are in the fields of energy efficiency, fuel switching, industrial processes, municipal solid waste (MSW), and renewable energy. Pending registration by the CDM executive board, India will generate a total of 627 million CERs before the end of 2012. At a price of INR 500 (USD 10) per CER, they would be worth INR 313.5 billion (USD 6.27 billion). In 2009, 478 of the world total 2,011 registered projects were generated by India. Only China had registered more. ${ }^{9}$ As of September 2010, India had 532 registered CDM projects, 426 of which were in the energy sector, with the overwhelming majority comprised of renewable energy projects. ${ }^{10}$

\subsection{Energy Sector Overview}

The electricity intensity of the Indian economy - the percentage growth of electricity consumption that correlates with $1 \%$ of economic growth-fell from approximately $3.14 \%$ in the 1950 s to $0.97 \%$ in the $1990 \mathrm{~s}$. ${ }^{11}$ In 2007 , it was at $0.73 \%$. The main reason for this reduction is that India's growth until now was based more on the service sector (with an electricity intensity of only $0.11 \%$ ) than on growth in industrial production (with an electricity intensity of $1.91 \%) .{ }^{12}$ Today, for each $1 \%$ of economic growth, India needs around

\footnotetext{
${ }^{8}$ UNFCCC. "Clean Development Mechanism—About CDM.” http://cdm.unfccc.int/about/index.html. Accessed May 2010.

${ }^{9}$ Ministry of Environment and Forests. Annual Report 2009-2010. pp. 269-270.

http://moef.gov.in/report/report.html. Accessed August 2010.

${ }^{10}$ CDM. "Project Search.” http://cdm.unfccc.int/Projects/projsearch.html. Accessed July 2010.

${ }^{11}$ Indiacore. "Overview of Indian Power Sector.” http://www.indiacore.com/power.html. Accessed August 2010.

${ }^{12}$ McKinsey. "Powering India: The Road to 2017." 2009 (unpublished).
} 
$0.75 \%$ of additional energy. ${ }^{13}$ The Planning Commission of India, which coordinates Indian long-term policy, analyzes different scenarios; one scenario assessed that this value could fall to $0.67 \%$ between $2021-2022$ and $2031-2032 .{ }^{14}$

India is facing a formidable challenge to build up its energy infrastructure fast enough to keep pace with economic and social changes. Energy requirements have risen sharply in recent years, and this trend is likely to continue in the foreseeable future. It is driven by India's strong economic and population growth as well as by changing lifestyle patterns. Growth and modernization essentially follow the energy-intensive Western model of the $19^{\text {th }}$ and $20^{\text {th }}$ centuries, in which economic growth correlates with a comparable growth in the energy use.

For GDP annual growth of $8 \%$, the Planning Commission estimates that the commercial energy supply would have to increase at the very least by three to four times by 2031-2032 and the electricity generation capacity by five to six times over $2003-2004$ levels. ${ }^{15}$ In $2031-$ 2032, India will require approximately 1,500-2,300 million tonnes of oil equivalent (MTOE) to cover its total commercial energy needs. ${ }^{16}$ The Indian government by itself does not have sufficient financial resources to solve the problem of energy shortages. It must rely on cooperation with the private sector to meet future energy requirements. This opens up interesting market opportunities for international companies.

In the study "Powering India: The Road to 2017," the management consultancy McKinsey calculated that goals specified by the Indian government have been set too low. ${ }^{17}$ The study argues that the peak demand will be 315 and $335 \mathrm{GW}$ by 2017 instead of by only $213 \mathrm{GW}$ as estimated in 2007 by the Central Electricity Authority (CEA) and 226 GW (assuming 8\% annual GDP growth) estimated in the Integrated Energy Policy (see Figure 1-1). Accordingly, by 2017 , India would require a total installed capacity of $415-440 \mathrm{GW}$ in order to be able to reliably meet this demand. This means that over the next 9 years, the country would have to install more than twice as much capacity as it has been able to install over the last 60 years $(159 \mathrm{GW})$. In order to achieve this, the speed with which the new capacities are built must increase five-fold. Such a massive increase requires a fundamental restructuring of the entire power market, which the government has begun through enactment of the Electricity Act (discussed in Section 1.3 and Chapter 2).

\footnotetext{
${ }^{13}$ BP. "Statistical Review of the World Economy, 2009."

http://www.bp.com/liveassets/bp internet/globalbp/globalbp uk english/reports and publications/statistical en ergy review_2008/STAGING/local_assets/2009 downloads/statistical_review of world_energy_full_report_2 009.pdf. Accessed September 2010. Calculation based on the figures of 2000-2008.

${ }^{14}$ Government of India Planning Commission. "Integrated Energy Policy-Report of the Expert Committee 2006.” August 2006; pp. 18-19. http://planningcommission.nic.in/reports/genrep/rep_intengy.pdf. Accessed September 2010.The study indicates that the international average value is $0,83 \%$, whereby countries with a higher GDP (over USD 8,000 per person per year) tend to have a lower average energy elasticity of $0.76 \%$ (see p. 19).

${ }^{15}$ Government of India Planning Commission. "Integrated Energy Policy—Report of the Expert Committee." August 2006; p. 13 (overview). Online http://planningcommission.nic.in/reports/genrep/rep_intengy.pdf. Accessed September 2010.

${ }^{16}$ Government of India Planning Commission. "Integrated Energy Policy-Report of the Expert Committee." August 2006; p. 20. Online http://planningcommission.nic.in/reports/genrep/rep intengy.pdf. Accessed September 2010.

${ }^{17}$ McKinsey. "Powering India: The Road to 2017." 2009 (unpublished).
} 


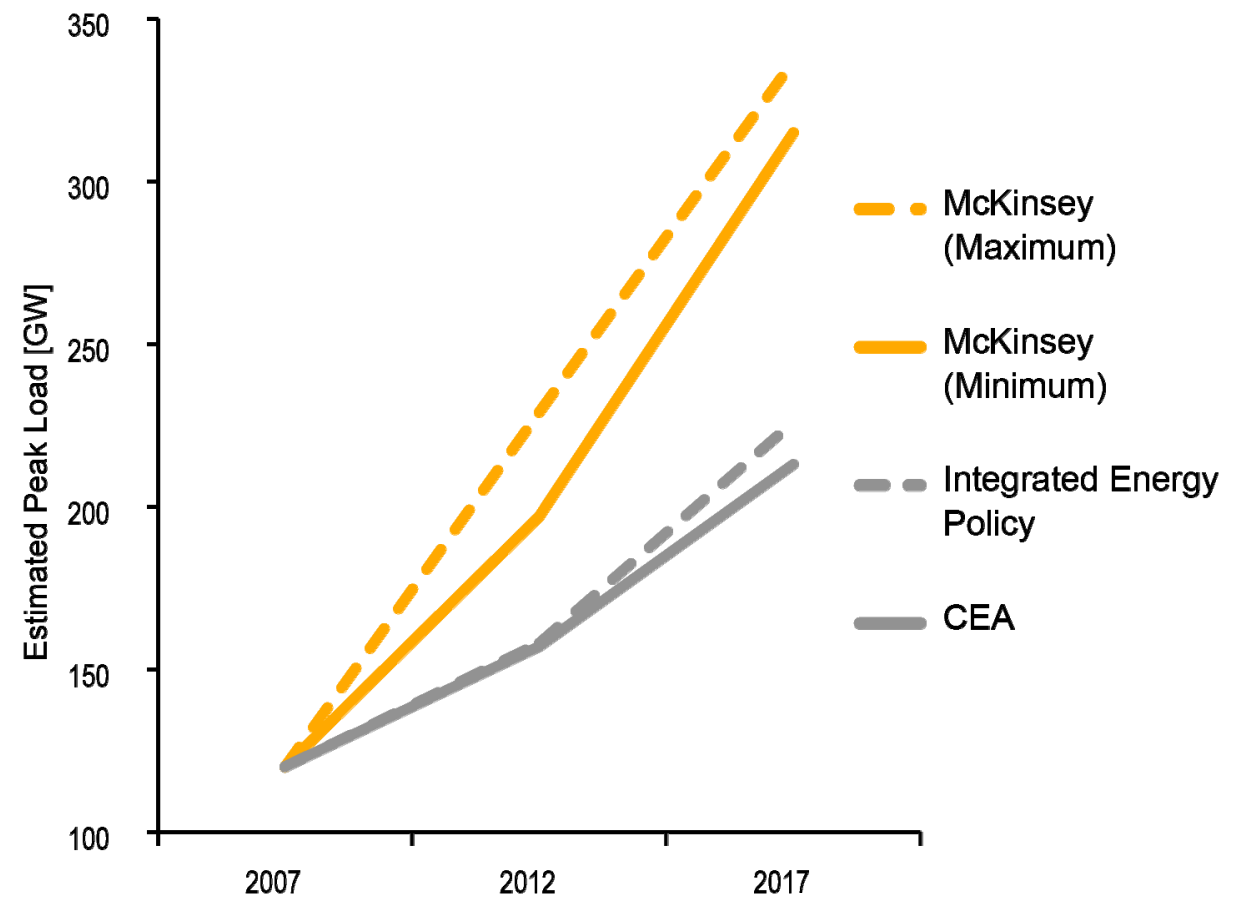

Figure 1-1. Scenarios for the development of necessary peak load capacities ${ }^{18}$

\subsubsection{Commercial Energy Consumption}

As shown in Figure 1-2, India's share of the global commercial energy ${ }^{19}$ consumption in 2008 was $3.8 \%$ (433 of 11,295 MTOE), increased from $2.9 \%$ over the past 10 years, thus making it the fifth largest consumer of commercial energy. By comparison, China holds $19.6 \%$ of the population and consumes $17.7 \%$ of commercial energy.

\footnotetext{
${ }^{18}$ McKinsey. "Powering India: The Road to 2017." 2009 (unpublished).

19 Commercial energy resources contain all the commercially traded fuels. Although they play a major role in many countries, wood, peat, and animal wastes are not included because no reliable statistics are available.
} 


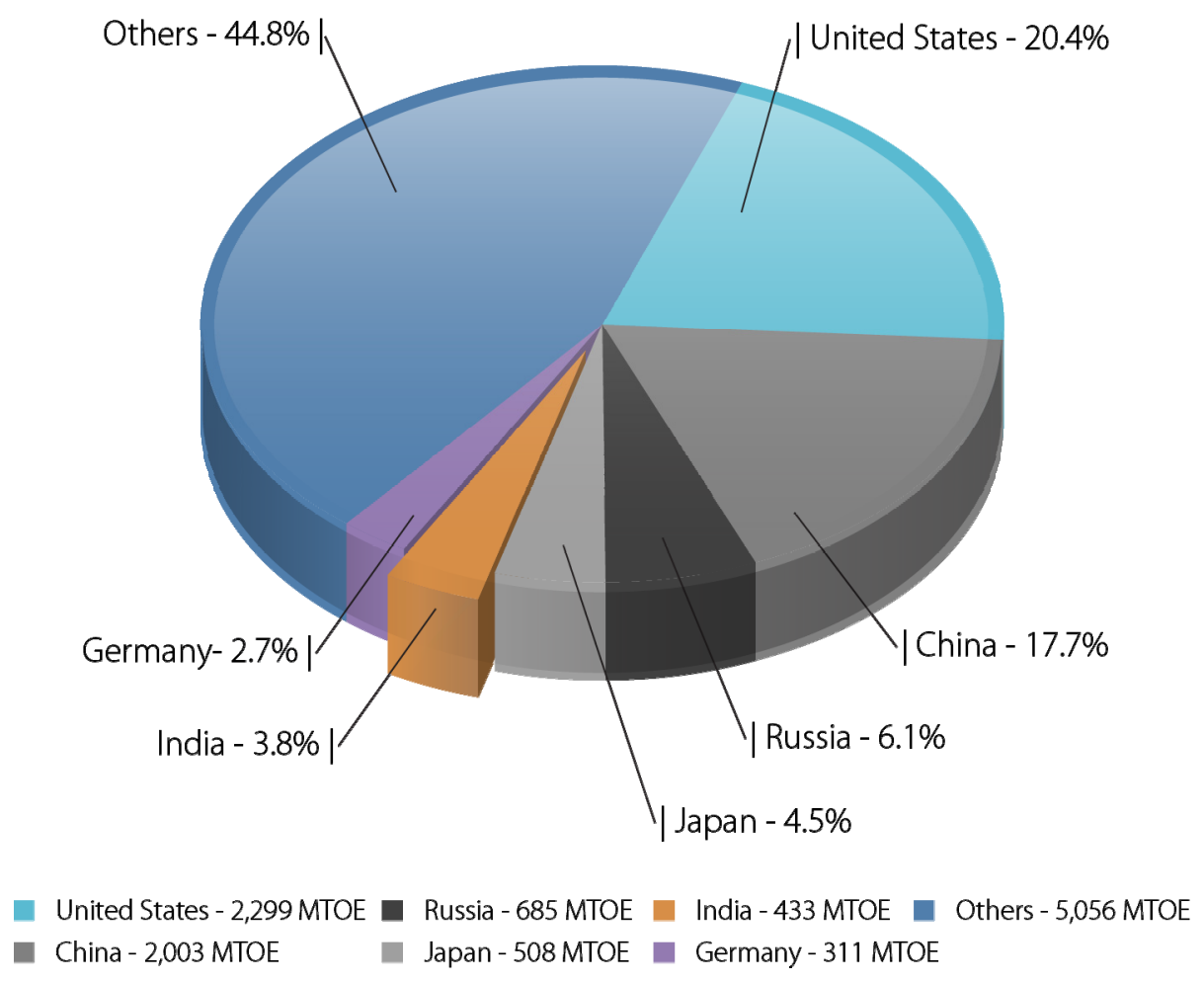

Figure 1-2. Worldwide consumption of primary sources of energy by country $(2008)^{20}$

India's total consumption of commercial energy increased from 295 MTOE in the year 2000 to $433 \mathrm{MTOE}$ in 2008 with an average annual growth rate of $4.9 \%$ (see Figure 1-3).

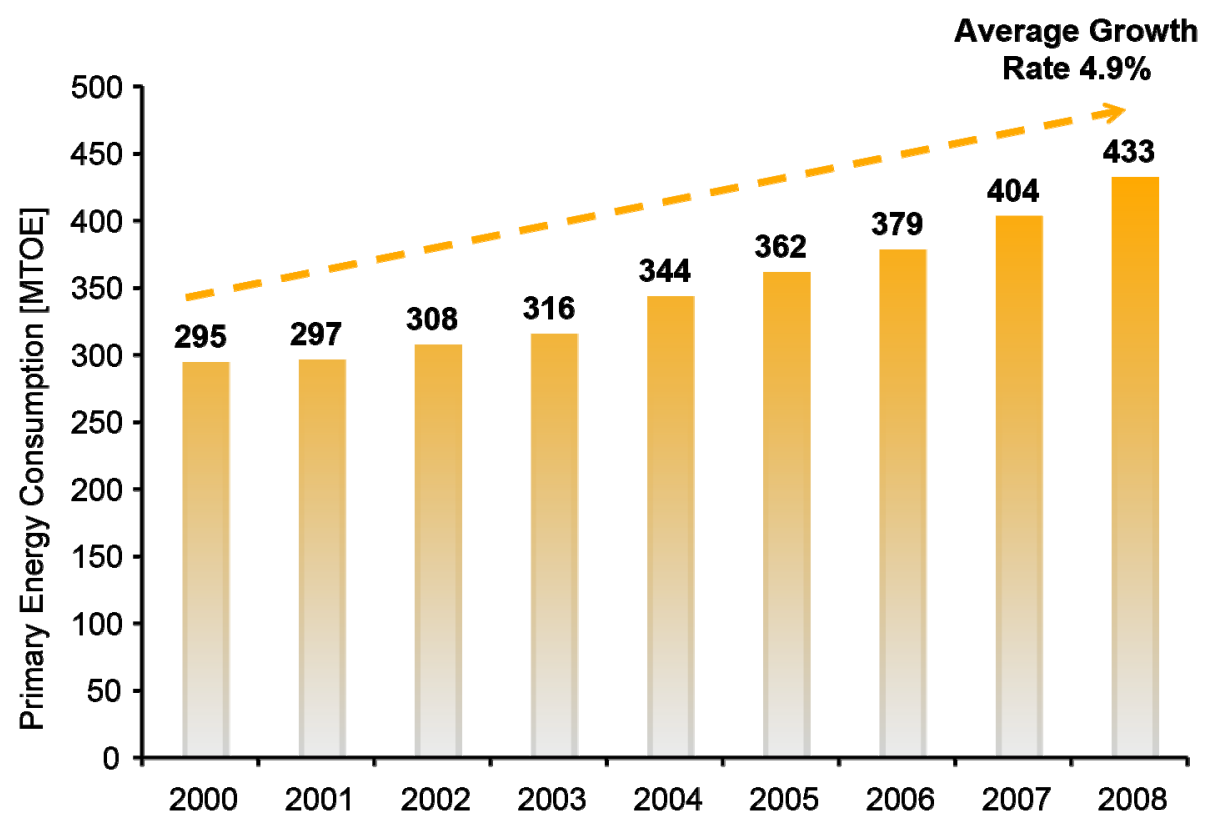

Figure 1-3. Development of commercial energy consumption in India ${ }^{21}$

\footnotetext{
${ }^{20}$ BP. "Statistical Review of World Energy, 2009."

http://www.bp.com/liveassets/bp_internet/globalbp/globalbp_uk_english/reports and_publications/statistical_en ergy_review_2008/STAGING/local_assets/2009_downloads/statistical_review_of_world_energy_full_report_2 009.pdf. Accessed September 2010.
} 
Coal is by far the most important energy source for India; it provides more than half of the commercial energy supply. Oil, mostly imported, is the second most important source of energy, followed by gas and hydropower (see Figure 1-4). So far, nuclear (atomic) power covers only a small portion of the commercial energy requirement (approximately $1.5 \%$ ). With less than $1 \%$, renewable energy plays a minor role (this does not include hydro $>25$ MW), and therefore, it is not even visible in Figure 1-3, though its share is projected to increase significantly. The traditional use of biomass (e.g., for cooking) has not been included here as a source of energy. However, the 2001 Census points out that approximately 139 million of the total 194 million households ${ }^{22}$ in India (72\%) are using traditional forms of energy such as firewood, crop residue, wood chips, and cow dung cakes for cooking. ${ }^{23}$ The majority of these households are in rural areas. Firewood, used by approximately 101 million households, is the main cooking fuel in India.

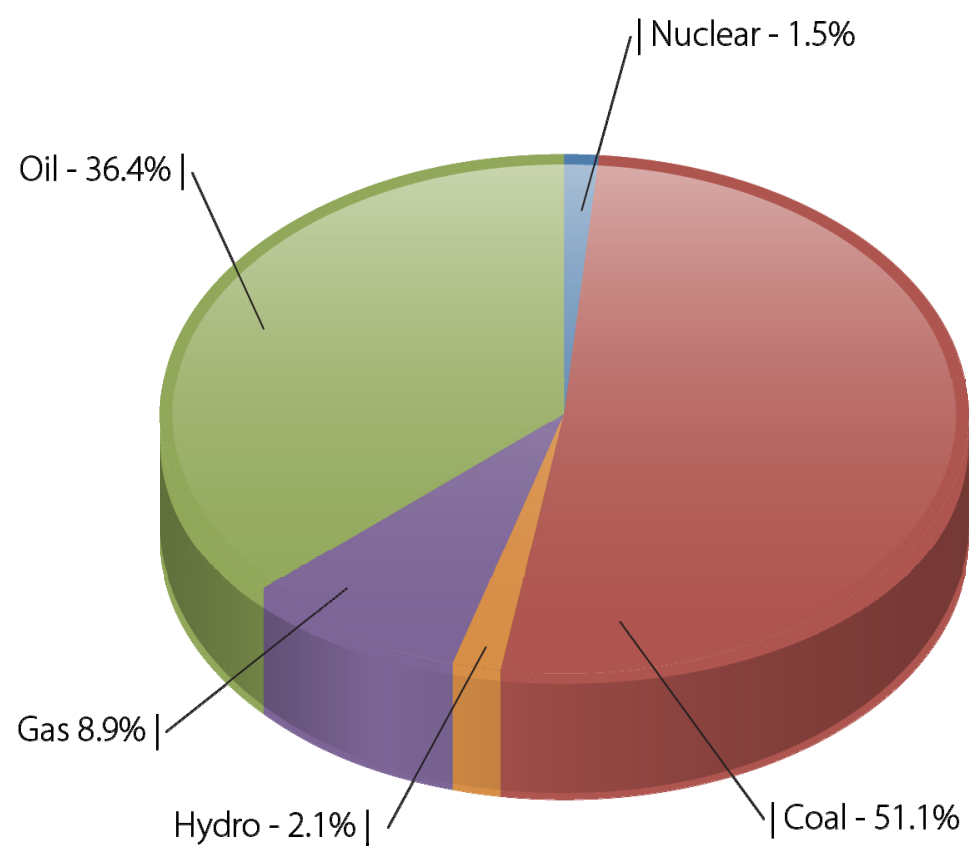

Figure 1-4. Percentage share of commercial energy sources in India (2004)

\footnotetext{
${ }^{21}$ BP. "Statistical Review of World Energy, 2009."

http://www.bp.com/liveassets/bp internet/globalbp/globalbp uk english/reports and publications/statistical en ergy_review_2008/STAGING/local_assets/2009_downloads/statistical_review_of_world_energy_full_report_2 009.pdf. Accessed September 2010.

${ }^{22}$ Census of India. "2001 Data Highlights."

http://censusindia.gov.in/Data_Products/Data_Highlights/Data_Highlights_link/data_highlights_hh1_2_3.pdf. Accessed October 2010.

${ }^{23}$ Census of India. "Fuel Used for Cooking."

http://censusindia.gov.in/Census_Data_2001/Census_data_finder/HH_Series/Fuel_used_for_cooking.htm.

Accessed October 2010.

${ }^{24}$ Government of India Planning Commission. "Integrated Energy Policy—Report of the Expert Committee." August 2006; p. 29. Online http://planningcommission.nic.in/reports/genrep/rep intengy.pdf. Accessed September 2010
} 


\subsection{The Power Market in India and the Role of Renewable Energy}

While India has been making progress in different infrastructural areas such as the construction of roads and expansion of the telecommunication system, the power infrastructure has not kept pace with the growing requirements.

India's power market is confronted with major challenges regarding the quantity as well as the quality of the electricity supply. The base-load capacity will probably need to exceed 400 GW by 2017. In order to match this requirement, India must more than double its total installed capacity, which as of March 2010 was $159 \mathrm{GW} .{ }^{25}$ Moreover, India's power sector must ensure a stable supply of fuels from indigenous and imported energy sources, provide power to millions of new customers, and provide cheap power for development purposes, all while reducing emissions. On the quality side, the electricity grid shows high voltage fluctuations and power outages in almost all parts of the country on many days for several hours. ${ }^{26}$ According to the "Global Competitiveness Report," in 2009-2010 (weighted average), India ranked 110 among 139 countries in the category "Quality of Electricity Supply.",27

The power deficit reported for 2008-2009 was almost 84 TWh, which is almost $10 \%$ of the total requirement; the peak demand deficit was more than $12.7 \%$ at over $15 \mathrm{GW}{ }^{28}$ The electricity undersupply in India is estimated to cost the economy as much as INR 34 (USD 0.68 ) to INR 112 (USD 2.24) for each missing kilowatt-hour. Thus, the total cost of the power deficit of 85 billion $\mathrm{kWh}$ in financial year 2007-2008 amounted to at least INR 2,890 billion (USD 58 billion), or almost $6 \%$ of the GDP. ${ }^{29}$ Another report states that there is an approximately $7 \%$ decrease in the turnovers of Indian companies due to power cuts. ${ }^{30}$ As a consequence, many factories, businesses, and private customers have set up their own power generation capacities in the form of captive power plants or diesel generators in order to ensure their power supply. This provides an attractive opportunity for renewable energy solutions; they compete not with power produced relatively cheaply by large coal plants but with much more expensive diesel back-up generators.

Until 1991, the Indian government monopolized the power market. There were only a few private actors, and the CEA had sole responsibility for giving techno-economic clearance to new plants. However, the public sector has been unable to cater to the growing demand for power, and in the future, investment requirements in the public sector will far exceed the resources. Current energy policies therefore place an emphasis on the integration of the private sector along the entire value chain: from the generation of power to transmission and distribution.

\footnotetext{
${ }^{25}$ CEA. http://www.cea.nic.in/. Accessed September 2010.

${ }^{26}$ Power Line. "Impetus to T\&D." June 2009.

${ }^{27}$ World Economic Forum. "The Global Competitiveness Report 2010-2011.” Geneva, Switzerland, 2010; p. 394; http://www3.weforum.org/docs/WEF_GlobalCompetitivenessReport_2010-11.pdf. Accessed September 2010.

${ }^{28}$ CEA. "Power Sector Reports." http://www.cea.nic.in/power_sec reports/reports.htm. Accessed August 2010.

${ }^{29}$ Wärtsilä. "The Real Cost of Power." 2009.

http://www.wartsila.com/Wartsila/india/docs/locals/india/AboutUs/RCOP28july2009.pdf. Accessed September 2010.

${ }^{30}$ O’Neill, J.; Poddar, T. “Global Economics Paper No: 169.” Goldman Sachs.

http://www2.goldmansachs.com/ideas/brics/ten-things-doc.pdf. Accessed September 2010.
} 
The Electricity Act 2003 displaced former energy laws and expanded them comprehensively. ${ }^{31}$ The aim of the act was the modernization and liberalization of the energy sector through the implementation of a market model with different buyers and sellers. The main points included making it easier to construct decentralized power plants, especially in rural areas and for captive use by communities, and giving power producers free access to the distribution grid to enable wheeling. Producers could also choose to sell power directly to consumers rather than through the financially weak State Electricity Boards (SEBs). Through the Electricity Act, the different legal frameworks are to be unified at a state level to promote foreign direct investment in the country.

Given the long-term energy deficit and the growth trajectory of the Indian economy, the Indian investment community has responded positively. However, international investors are still hesitant. The largest barrier to more foreign private investment in the energy market is the energy price itself. In many customer sections and regions, they are too low to generate stable and attractive returns. Despite being an impractical drain on resources, the government has so far failed to adjust prices. The key reason is that cheap or free electricity is an important political token in a country where the majority of the population still lives on a very low income. ${ }^{32}$

\subsubsection{Power Consumption}

India's average power consumption per person was $733 \mathrm{kWh}$ in 2009 , and the average annual rate of increase since 2003 was $4.4 \%,{ }^{33}$ as shown in Figure 1-5.

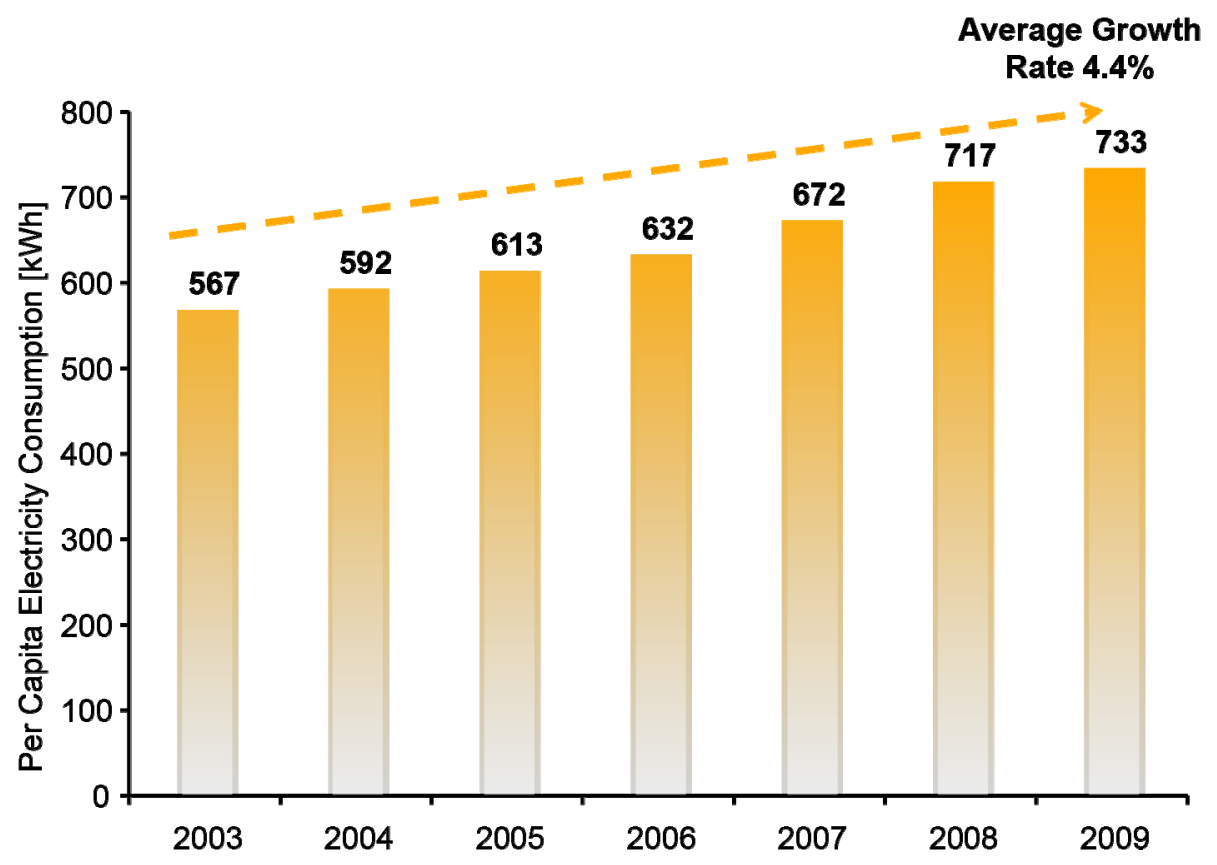

Figure 1-5. Per capita annual electricity consumption in India ${ }^{34}$

\footnotetext{
31 Sumir Lal. "Can Good Economics Ever Be Good Politics: Case Study of India's Power Sector.” World Bank Working Paper No. 83. 2006; p. 16.

${ }^{32}$ Sumir Lal. "Can Good Economics Ever Be Good Politics: Case Study of India's Power Sector.” World Bank Working Paper No. 83. 2006; pp. 3-5.

${ }^{33}$ CEA. "Monthly Review of Power Sector (Executive Summary)" August 2010. http://www.cea.nic.in/power_sec_reports/executive_summary/2010_08/1-2.pdf. Accessed October 2010. ${ }^{34}$ CEA. "Monthly Review of Power Sector (Executive Summary)" August 2010. http://www.cea.nic.in/power sec reports/executive summary/2010 08/1-2.pdf. Accessed October 2010.
} 
In 2008, a total of 596,943 GWh were consumed in India. The largest consumer was industry with 274,531 GWh (46\%), followed by households with 124,562 GWh (21\%), and agriculture with 107,835 GWh (18\%). In the commercial sector (e.g., offices and shops), $48,047 \mathrm{GWh}(8 \%)$ were consumed, 11,615 GWh (2\%) in rail traffic, and 30,353 GWh (5\%) in various other sectors. ${ }^{35}$

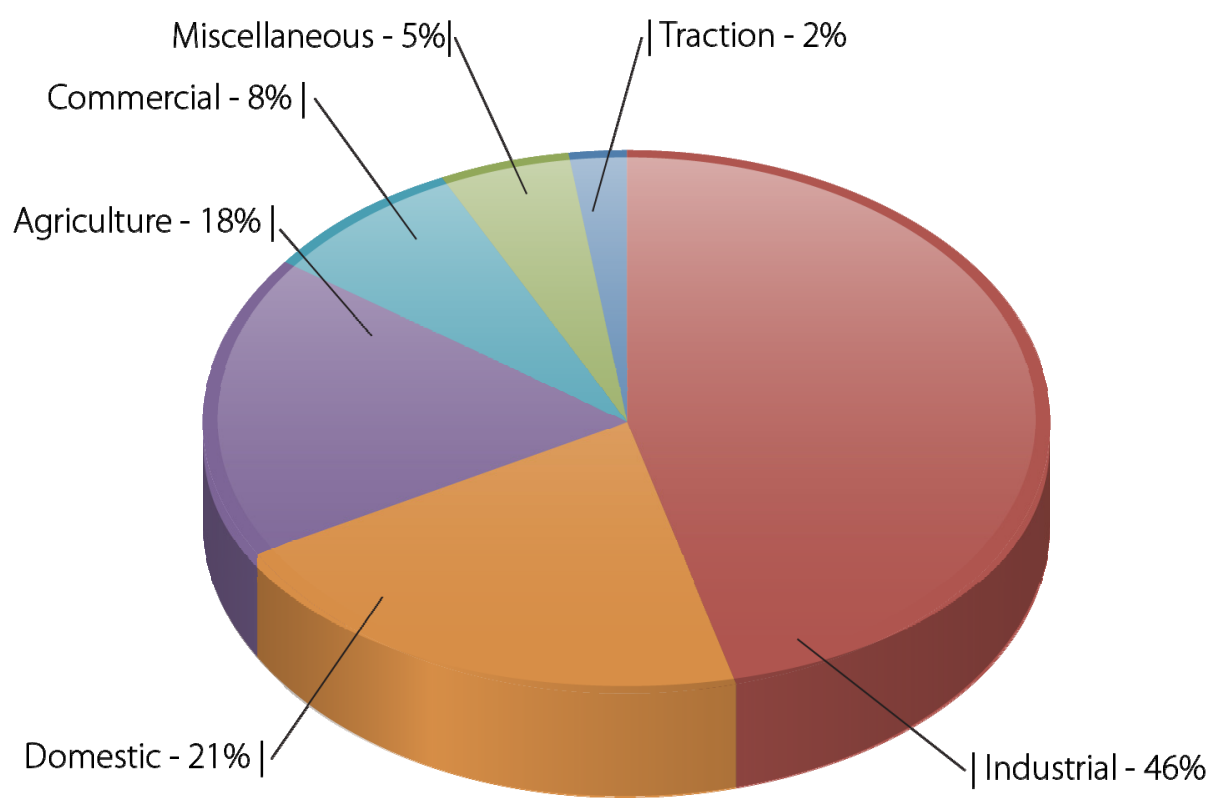

Figure 1-6. India electricity consumption sector-wise (utilities \& non-utilities, 2008-2009) ${ }^{36}$

Between 1980 and 2009, energy consumption increased by almost seven times from 85,334 GWh to 596,943 GWh, which corresponds to an average annual growth rate of approximately $7.1 \%$. The strongest increase was the consumption by private households, which increased by almost 14 times since 1980 at an average annual growth rate of $10 \%$. The reason for this increase was the inclusion of several million new households, corresponding to the increase in electrical household appliances such as refrigerators and air conditioners. The agricultural share increased seven-fold at an annual growth rate of $7.6 \%$ between 1980 and 2008 . The reason for a strong growth in the agricultural sector is, first, the inclusion of more rural areas, and second, the provision of power to farmers at reduced, or even free, rates in many areas. The consequence of this latter practice was the widespread purchase of cheap and inefficient water pumps that continue to run almost uninterrupted. The slowest growth in power consumption was seen in the industrial sector at $5.9 \%$ per year, which still corresponds to a five-fold increase. ${ }^{37}$

The main drivers for the strong growth in the demand for power are the overall economic growth, the power-intensive manufacturing industry that is growing disproportionately fast, the rapidly rising consumption in households due to the affordability of new electrical appliances, the planned provision of power to 96,000 currently un-electrified villages, and the

\footnotetext{
${ }^{35}$ CEA. "All India Electricity Statistics_-General Review." New Delhi: CEA. 2009.

${ }^{36}$ CEA. "Growth of Electricity Sector in India from 1947-2009." New Delhi: CEA, 2009.

${ }^{37}$ India Core. "Overview of Power Sector in India, 2008." New Delhi: India Core Publishing, 2008.
} 
provision of power for latent demand, which is currently unfulfilled because of frequent power cuts. ${ }^{38}$

\subsubsection{Power Generation Capacity}

The total power generation capacity in India in March 2010 was $159 \mathrm{GW}$. Of this, $64.3 \%$ was fossil-fuel-fired power plants (coal, gas, and diesel), 23.1\% hydropower, 2.9\% nuclear power, and $9.7 \%$ renewable energy. ${ }^{39}$

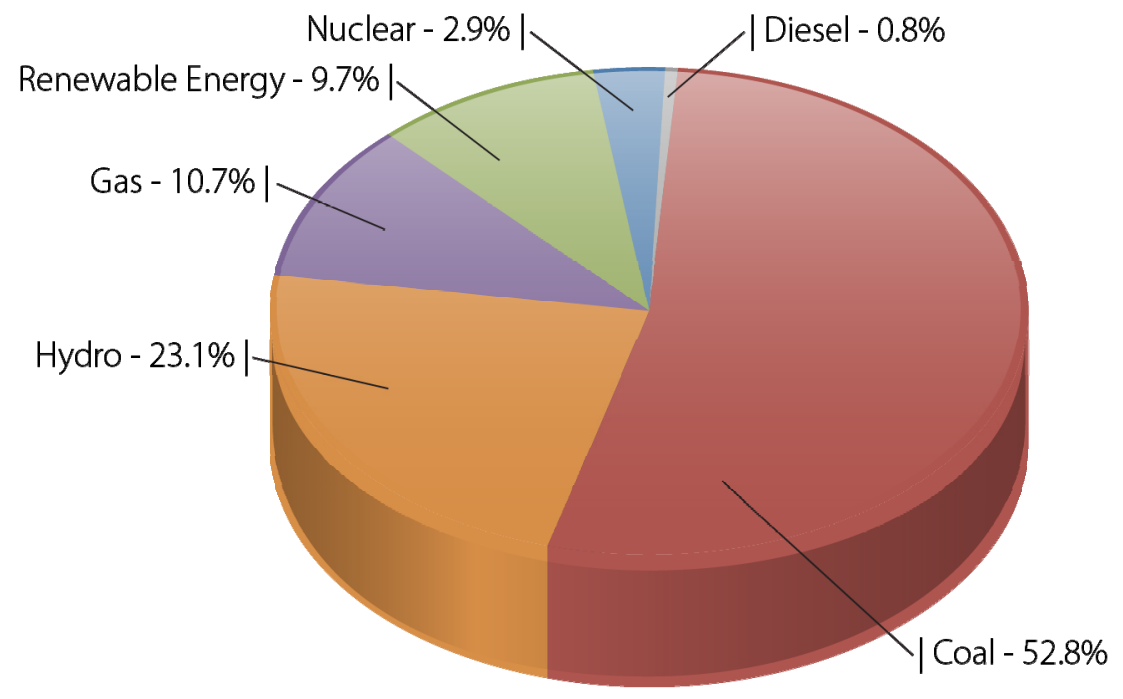
- Coal-84 GW
Hydro- 37 GW
Gas- 17 GW
Renewable Energy - 15 GW
- Nuclear-5 GW
Diesel- $1 \mathrm{GW}$

[Renewable energy includes small hydropower plants ( $<25 \mathrm{MW})$, biomass gasification, biomass energy, urban and industrial waste energy, solar energy, and wind energy.]

Figure 1-7. Installed capacities for power generation in India according to energy source (March 2010) $^{40}$

The composition of the power sector has changed significantly in the last 30 years. The power generation capacity controlled directly by the central government has increased from $12 \%$ to $32 \%$. At the same time, the fraction of generation capacity controlled by the individual states fell from $83 \%$ to $50 \%$. Generation capacity controlled by the private sector more than tripled from $5 \%$ to $18 \%{ }^{41}$ The private sector dominates in power generation from renewable energy sources.

\footnotetext{
${ }^{38}$ McKinsey. "Powering India: The Road to 2017." 2009 (unpublished).

${ }^{39}$ CEA. "Monthly Review of Power Sector (Executive Summary)." March 2010.

http://www.cea.nic.in/power sec reports/executive summary/2010 03/1-2.pdf. Accessed October 2010.

${ }^{40}$ CEA. "Monthly Review of Power Sector (Executive Summary)" March 2010. http://www.cea.nic.in/power_sec reports/executive_summary/2010_03/1-2.pdf Accessed September 2010. ${ }^{41}$ MoP. “Annual Report, 2007-2008.” July 2008; p. 109. http://www.cea.nic.in/about us/Annual\%20Report/2007-08/annual report 07 08.pdf Accessed October 2010
} 


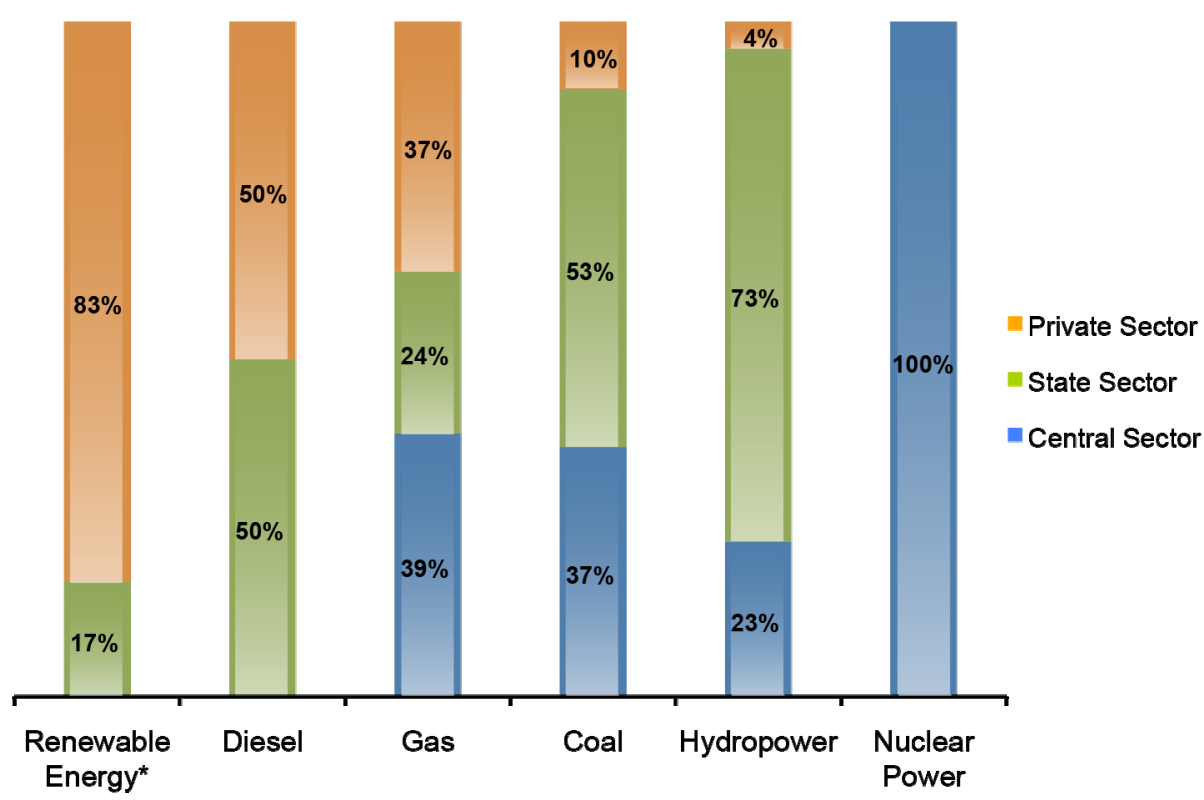

* Includes small hydropower plants $(<25 \mathrm{MW})$, biomass gasification, biomass energy, urban and industrial waste energy, solar energy, and wind energy.

Figure 1-8. Percentage of public and private sector power generation capacity by energy source (March 2010) ${ }^{42}$

The National Electricity Policy (NEP) assumes that the per capita electricity consumption will increase to $1,000 \mathrm{kWh}$ by 2012 . To cover this demand, the government is planning to add 78,700 MW of capacity during the Eleventh Five-Year Plan ${ }^{43}$ (Eleventh Plan) ending March 2012. As of April 2010, 22,552 MW of new installation toward that goal had been achieved. There are further projects under construction with a total capacity of 39,822 MW. As per the mid-term plan review, capacity additions of $62,374 \mathrm{MW}$ are likely to be achieved with a high degree of certainty and another $12,000 \mathrm{MW}$ with best efforts. ${ }^{44}$ Figure 1-9 shows India's capacity growth from the end of the Eighth Plan in 1997 to projections through the end of the Eleventh Plan.

\footnotetext{
${ }^{42}$ CEA. "Monthly Review of Power Sector (Executive Summary)" March 2010. http://www.cea.nic.in/power_sec_reports/executive_summary/2010 03/27-33.pdf. Accessed October 2010.

${ }^{43}$ India's Five-Year Plans are planning documents for India's economy. See Section 2.3.1 of this report for a description of the planning process and renewable energy's role.

${ }^{44}$ CEA. "Summary Statement."

http://www.cea.nic.in/planning/Capacity\%20addition\%20target\%20during\%2011th\%20plan\%20set\%20by\%20 Planning\%20Commission\%20(Revised)-summary\%20region\%20wise.pdf. Accessed July 2010. "Summary of Likely Capacity Addition During $11^{\text {th }}$ Plan." http://www.cea.nic.in/planning/Feasible\%20capacity\%20addition\%20during\%2011th\%20Plan.pdf. Accessed July 2010.
} 


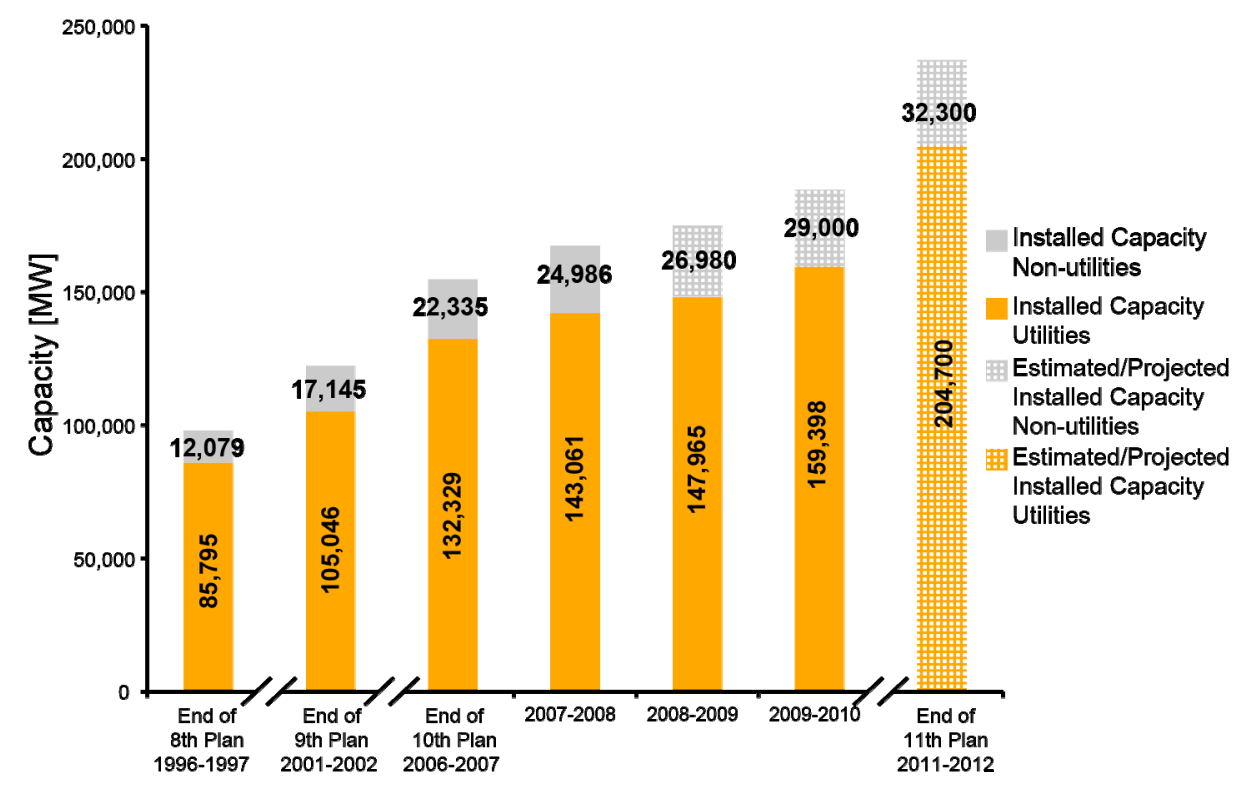

Figure 1-9. Development of installed electrical capacities of utilities and non-utilities in India ${ }^{45}$

Figure 1-10 shows the technology breakdown of the 78,700 MW targeted in the Eleventh Plan. The largest share of 59,693 MW is to be provided by thermal power plants.

Additionally, 15,627 MW is to be provided by hydro and 3,380 MW by nuclear power. The central government undertakings, such as those of the National Thermal Power Corporation or the National Hydro Power Corporation, will contribute the most. ${ }^{46}$

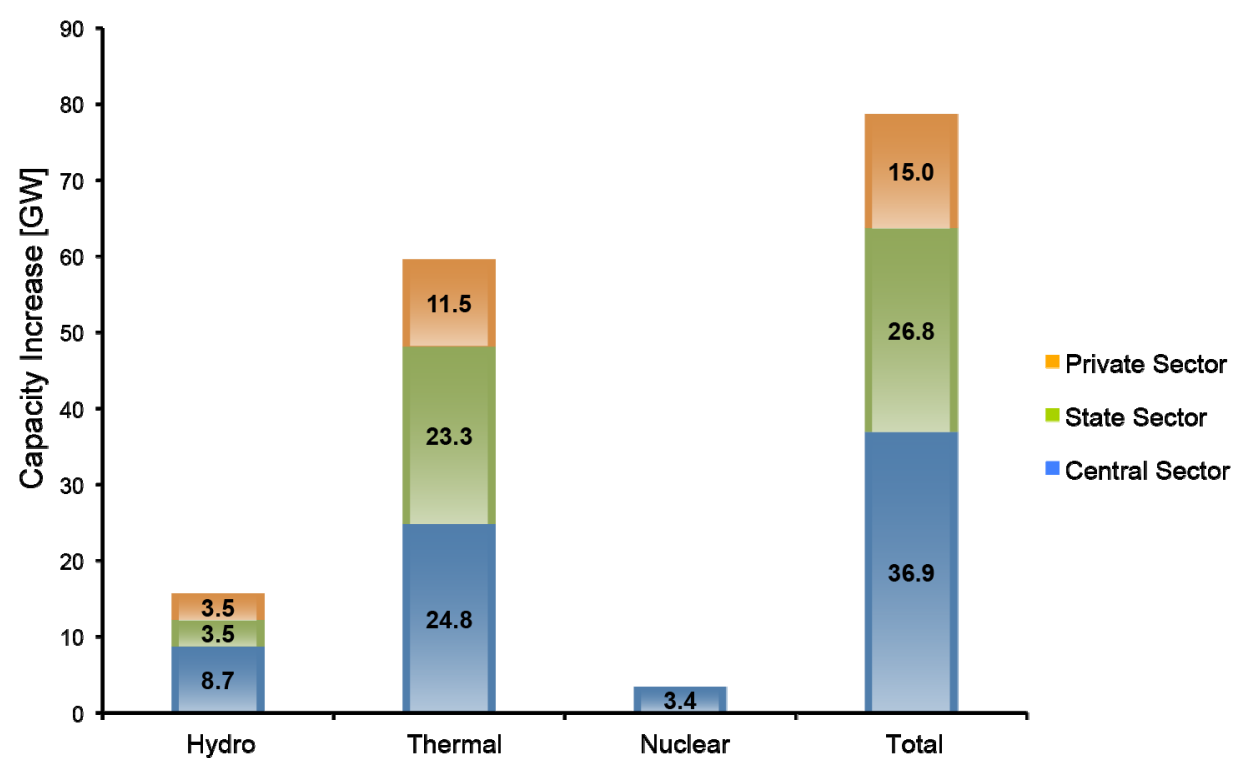

Figure 1-10. Forecast growth in capacity by the end of the Eleventh Plan according to sector $(2012)^{47}$

In March 2009, the gross electricity generation ${ }^{48}$ by utilities in India was $746.6 \mathrm{TWh}$. In addition, 95.9 TWh was generated by non-utilities and another 5.9 TWh were net imports.

\footnotetext{
${ }^{45}$ CEA. "Monthly Report: Executive Summary." March 2010; p. 11.

http://www.cea.nic.in/power_sec_reports/executive_summary/2010 03/11.pdf. Accessed September 2010.

${ }^{46}$ CEA. "Monthly Report: Executive Summary." March 2010; p. 4.

http://www.cea.nic.in/power_sec_reports/executive_summary/2010_03/4.pdf. Accessed September 2010.

${ }^{47}$ CEA. "Monthly Report: Executive Summary." March 2010.

http://www.cea.nic.in/power_sec_reports/executive_summary/2010 03/4.pdf. Accessed September 2010.
} 
The total generation available was thus $848.4 \mathrm{TWh}$, which corresponds to a rise of $3.3 \%$ as compared to the previous year. ${ }^{49}$ As these figures show, the trend in growth rates is inadequate in view of the rapid increase in demand for power.

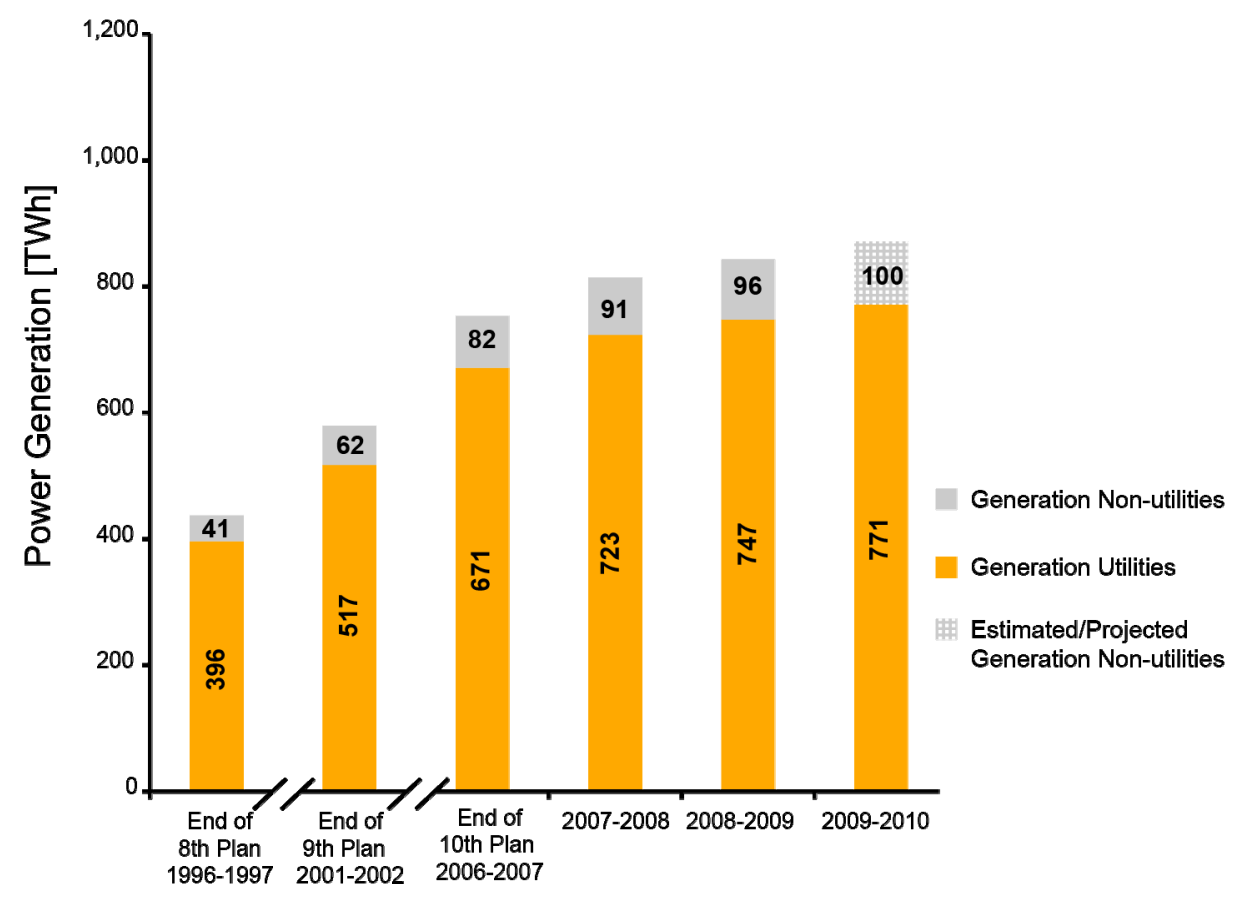

Figure 1-11. Power generation in India ${ }^{50}$

\subsubsection{Electricity Generation Efficiency}

Conventional thermal power generation in India faces three main challenges:

1. The low average conversion efficiency of the plants (30\%).

2. The low quality of the coal itself, which has high ash content and a low calorific value $(3,500-4,000 \mathrm{kcal} / \mathrm{kg}){ }^{51}$

3. The fixed electricity off-take price, which does not reward efficiency gains.

It is estimated that at least $25 \%-30 \%$ of the capacity in power plants in India is old and inefficient and operates at high heat rates and low utilization levels. ${ }^{52}$

To overcome these challenges, the Indian government has implemented a comprehensive program that includes a large-scale renovation and modernization (R\&M) program for existing power plants, the promotion of supercritical technology for Ultra Mega Power Projects at pithead locations, the promotion of use of imported higher quality coal (from South Africa, Australia, and Indonesia) for coastal locations, the set-up of coal washing facilities for domestic coal, and the promotion of an IGCC technology for gas plants. Also,

\footnotetext{
${ }^{48}$ Without inter alia deduction of own consumption of power stations (approximately $7 \%$ ) and grid losses (approximately 30\%).

${ }^{49}$ CEA. "All India Electricity Statistics-General Review.” New Delhi: CEA. 2009; p. 6.

${ }^{50}$ CEA. “All India Electricity Statistics_-General Review.” New Delhi: CEA. 2009; p. 6.

${ }^{51}$ Coal India Limited. "CIL to Spend Rs 2,000 cr to Build 20 New Washeries."

http://www.coalindia.in/NewsDisplay.aspx?NewsID=35\&NewsType=2. Accessed July 2010.

${ }^{52}$ CEA and National Thermal Power Corporation. "Energy Efficiency in Thermal Power Generation." Second Meeting of the Indo-German Energy Forum. December 2007.
} 
new power plant projects are being awarded via a competitive bidding process based on the lowest price offer for electricity sold to the grid.

Since 1985, nearly 400 units (over $40 \mathrm{GW}$ ) have been serviced through the R\&M program. According to The Energy and Resources Institute (TERI), R\&M could improve electricity generation by $30 \%$, reduce emissions by $47 \%$, and increase energy conversion efficiency by $23 \% .^{53}$

The R\&M program currently faces two challenges to successful completion. First, the rising electricity demand makes it difficult to take plants off the grid for maintenance work. Second, sometimes the costs to repair or upgrade old power generation equipment exceed $50 \%$ of the costs of an entirely new plant. In such cases, repair is not economically viable. However, given the rising demand, such plants cannot be taken off the grid either. Although many newer, privately operated plants are more efficient than state-owned plants, there is still a technology deficit across the power generation sector, mainly with respect to the latest supercritical technology. The performance of India's existing supercritical power plants has so far failed to meet expectations. ${ }^{54}$ This presents a great opportunity for international technical cooperation.

\subsubsection{Transmission and Distribution Technical and Commercial Losses}

India's electricity losses are among the highest in the world. In 2000, they were at a national average of $40 \%$; in 2005 , they were still at $30 \%$; and in 2009 , they were at $27 \%$. The Indian government aims to bring losses down to $20 \%$ by $2012,{ }^{55}$ which is still far above the international average where figures well below $10 \%$ are considered appropriate.

Reasons for this high percentage of loss include a lack of investment into the grid, widespread power theft, and a lack of consumption monitoring. In addition, a large amount of electricity is freely provided to certain consumers (e.g., farmers). Both the losses and the wasteful distribution of free electricity weaken the financial position of the SEBs, thereby reducing their capabilities to invest in grid infrastructure.

In 2008, the government set up an INR 19.46 billion (USD 389 million) fund under the Restructured Accelerated Power Development and Reform Program from which SEBs could take out loans in order to finance grid improvements. The program was only moderately successful since the conditions of the loans did not create sufficient incentives. ${ }^{56}$ There are, however, a few examples of successful reductions in electricity losses. Gujarat has managed to bring down losses from $30 \%$ in 2005 to $20 \%$ in 2009 by isolating the wasteful rural electricity consumption and then monitoring and optimizing it. ${ }^{57}$ A second approach, which has so far been implemented only in large cities, is to involve the private sector by selling or franchising the existing infrastructure to private operators. This has been successful in Delhi,

\footnotetext{
${ }^{53}$ Srivastava, N.K.; Ramesh, M.S.; Ramakrishnan, N.A. "NTPC R\&M Case Study." http://docs.google.com/viewer?a=v\&q=cache:WTd3MT6GQ4oJ:www.enercon.gov.pk/Symposium/IINKSrivastava.pdf+http://www.energymanagertraining.com/Presentations2008/Indo-GermanSymposium1516May2008/15-05-08Presentations/II-

NKSrivastava.pdf\&hl=de\&pid=bl\&srcid=ADGEESjtsxI_JqXIS3VKwdXdUmADswmYTVHElM89fRStUfUB 9bpHnYs0JgCS8HWUjc7Nez9F_jQTdn1WB8ola-Zsqrcv_1oM158k81qu47PuGSgRgtQp7hHYxa9LPgZKbDSuLT8CuWf\&sig=AHIEtbRSI2CZQtPBCDxXXu1kDsbRqL1nzw. Accessed October 2010.

${ }^{54}$ Bhushan, C. "Challenge of the New Balance.” New Delhi: Centre for Science and Environment, 2010; p. 25.

${ }^{55}$ PowerLine. "Industrial Tariff Trends." August 2009.

${ }^{56}$ PowerLine. "Impetus to T\&D." June 2009.

${ }^{57}$ McKinsey. "Powering India: The Road to 2017." 2009 (unpublished).
} 
Mumbai, and Calcutta, all cities that have transmission losses that are lower than the national average.

Given that a large part of the country is not yet connected to the grid, India has the opportunity to create a more cost-effective and possibly climate-friendly decentralized electricity supply. India can even leapfrog ahead of developed countries by implementing renewable energy technologies where they are economically viable. The challenge is to develop a policy framework and functioning business models that attract investment into offgrid electricity generation. 


\section{The Status of Renewable Energy in India}

\section{Chapter Overview}

India has over $17 \mathrm{GW}$ of installed renewable power generating capacity. Installed wind capacity is the largest share at over $12 \mathrm{GW}$, followed by small hydro at $2.8 \mathrm{GW}$. The remainder is dominated by bioenergy, with solar contributing only $15 \mathrm{MW}$. The Eleventh Plan calls for grid-connected renewable energy to exceed $25 \mathrm{GW}$ by 2012 . JNNSM targets total capacity of $20 \mathrm{GW}$ grid-connected solar power by 2022. Renewable energy technologies are being deployed at industrial facilities to provide supplemental power from the grid, and over $70 \%$ of wind installations are used for this purpose. Biofuels have not yet reached a significant scale in India.

India's Ministry of New and Renewable Energy (MNRE) supports the further deployment of renewable technologies through policy actions, capacity building, and oversight of their wind and solar research institutes. The Indian Renewable Energy Development Agency (IREDA) provides financial assistance for renewable projects with funding from the Indian government and international organizations; they are also responsible for implementing many of the Indian government's renewable energy incentive policies. There are several additional Indian government bodies with initiatives that extends into renewable energy, and there have been several major policy actions in the last decade that have increased the viability of increased deployment of renewable technologies in India, ranging from electricity sector reform to rural electrification initiatives. Several incentive schemes are available for the various renewable technologies, and these range from investment-oriented depreciation benefits to generationoriented preferential tariffs. Many states are now establishing Renewable Purchase Obligations (RPOs), which has stimulated development of a tradable Renewable Energy Certificate (REC) program.

\subsection{Renewable Energy Share of Electricity}

As of June 2010, India was one of the world leaders in installed renewable energy capacity, with a total capacity of $17,594 \mathrm{MW}$ (utility and non-utility), ${ }^{58}$ which represents approximately $10 \%$ of India's total installed electric generating capacity. ${ }^{59}$ Of that total, $17,174 \mathrm{MW}$ were grid-connected projects, and the remaining $2.4 \%$ of installed renewable capacity consisted of off-grid systems. ${ }^{60}$

The wind industry has achieved the greatest success in India with an installed capacity of $12,009 \mathrm{MW}$ at the end of June 2010. India has also installed 2,767 MW of small hydro plants (with sizes of less than $25 \mathrm{MW}$ each), 1,412 MW of grid-connected cogeneration from bagasse, and $901 \mathrm{MW}$ of biomass-based power from agro residues. Waste-to-energy projects have an installed capacity of $72 \mathrm{MW}$.

India has off-grid renewable power capacities of $238 \mathrm{MW}$ from biomass cogeneration, 125 MW from biogas, $53 \mathrm{MW}$ from waste-to-energy, $3 \mathrm{MW}$ from solar PV plants, and $1 \mathrm{MW}$ from hybrid systems. ${ }^{61}$

\footnotetext{
${ }^{58}$ MNRE. "New \& Renewable Energy." http://www.mnre.gov.in/achievements.htm. Accessed October 2010.

${ }^{59}$ CEA. "Monthly Review of Power Sector (Executive Summary)." September 2010. http://www.cea.nic.in/power_sec reports/executive_summary/2010 09/1-2.pdf. Accessed October 2010.

${ }^{60}$ MNRE. "New \& Renewable Energy." http://www.mnre.gov.in/achievements.htm. Accessed October 2010.

${ }^{61}$ MNRE. "New \& Renewable Energy." http://www.mnre.gov.in/achievements.htm. Accessed October 2010.
} 
With the recently announced JNNSM described in Chapter 4, India hopes to develop more of its solar resource potential. As of June 2010, solar PV plants in India had reached a cumulative generation capacity of approximately $15.2 \mathrm{MW}$. This is approximately $0.07 \%$ of JNNSM's 2022 target of $22 \mathrm{GW} .{ }^{62}$ As reported by CSP Today, JNNSM's goal would "make India the producer of almost three-quarters of the world's total solar energy output."

By the end of the Tenth Plan (2007), India achieved a cumulative installed capacity of $10.161 \mathrm{GW}$ of renewable energy (see Table 2-1). Additions totaling $15 \mathrm{GW}$ are targeted during the Eleventh Plan to bring the total installed grid-connected renewable generating capacity to over $25 \mathrm{GW}$. Wind energy is expected to contribute approximately two-thirds of the added capacity in this plan period. If India is able to achieve its renewable energy goals by 2022 (by the end of the Thirteenth Plan), it will reach a total of $74 \mathrm{GW}$ of installed capacity for wind, solar energy, biomass, and small hydropower, with wind and solar expected to account for more than $80 \%$ of the installed renewable power.

Table 2-1. Development of Grid-connected Renewable Power in India (in MW) ${ }^{64}$

\begin{tabular}{|l|l|l|l|l|l|}
\hline & \multicolumn{2}{|c|}{ Achieved } & \multicolumn{1}{|c|}{ In Process } & \multicolumn{1}{|c|}{ Anticipated } & \multicolumn{1}{|c|}{ Targets } \\
\hline $\begin{array}{l}\text { Five-year } \\
\text { Plan }\end{array}$ & $\begin{array}{l}\text { By the End of } \\
\text { the } 9^{\text {th }} \text { Plan } \\
\text { (cumulative } \\
\text { installed } \\
\text { capacity) }\end{array}$ & $\begin{array}{l}10^{\text {th }} \text { Plan } \\
\text { (additions } \\
\text { during plan } \\
\text { period) }\end{array}$ & $\begin{array}{l}\text { Anticipated in } \\
\text { the } 11^{\text {th }} \text { Plan } \\
\text { (additions } \\
\text { during plan } \\
\text { period) }\end{array}$ & $\begin{array}{l}\text { By the End of } \\
\text { the } 11^{\text {th }} \text { Plan } \\
\text { (cumulative } \\
\text { installed } \\
\text { capacity) }\end{array}$ & $\begin{array}{l}\text { By the End of } \\
\text { the } 13^{\text {th }} \text { Plan } \\
\text { (cumulative } \\
\text { installed } \\
\text { capacity) }\end{array}$ \\
\hline Years & Through 2002 & $2002-2007$ & $2007-2012$ & Through 2012 & Through 2022 \\
\hline Wind & 1,667 & 5,415 & 10,500 & 17,582 & 40,000 \\
\hline Small Hydro & 1,438 & 520 & 1,400 & 3,358 & 6,500 \\
\hline Biomass & 368 & 750 & 2,100 & 3,218 & 7,500 \\
\hline Solar & 2 & 1 & 1,000 & 1,003 & $20,000^{65}$ \\
\hline Total & $\mathbf{3 , 4 7 5}$ & $\mathbf{6 , 6 8 6}$ & $\mathbf{1 5 , 0 0 0}$ & $\mathbf{2 5 , 1 6 1}$ & $\mathbf{7 4 , 0 0 0}$ \\
\hline
\end{tabular}

Although the government provides assistance for renewable energy implementation in the form of generation-based incentives (GBIs), subsidies, subsidized credits, and reduced import duties, the Indian market does not offer investors a framework that is as investor-friendly as in some developed countries. The main reason is that renewable energy sources are not systematically prioritized over non-renewable sources at a given national budget and a given power demand scenario. While the market certainly offers great opportunities for investors, it also requires adaptation and entrepreneurship to develop solutions that specifically fit the Indian scenario.

Off-grid applications for rural electrification and captive power for industries offer a promising opportunity for renewable energy technologies in India. Both of these applications can benefit from renewable energy's advantages over conventional energy sources: local control of the energy resource and power system and suitability to smaller-scale applications. Renewable energy's competition is typically either a costly connection to the national grid or

\footnotetext{
${ }^{62}$ MNRE. "Jawaharlal Nehru National Solar Mission: Towards Building Solar India." http://mnre.gov.in/pdf/mission-document-JNNSM.pdf. Accessed October 2010.

${ }^{63}$ CSP Today. "India's 'New Solar Mission' Opens Doors for Fast Development for the Concentrated Solar Thermal Industry Worldwide." 28 May 2010.

${ }^{64}$ Government of India Planning Commission. "Eleventh Five Year Plan-2007-12." p. 387. http://planningcommission.nic.in/plans/planrel/fiveyr/11th/11_v3/11th_vol3.pdf. Accessed September 2010.

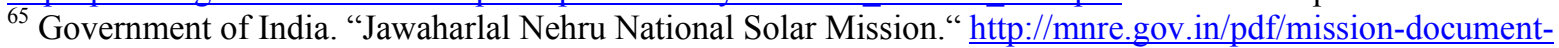
JNNSM.pdf. Accessed September 2010.
} 
diesel generator-based power with its high maintenance and fuel costs. On average, the cost of producing power for a coal plant is about INR 2 (USD 0.03) per $\mathrm{kWh}$, while electricity from a diesel generator plant is approximately INR 10 (USD 0.20) per $\mathrm{kWh}$. To compete effectively with these established technologies, renewable energy technologies require business models adapted to the characteristics of renewable power plants that include plans for efficient marketing, distribution, operation and maintenance, and access to financing.

For on-grid application of renewable energy, growth depends on grid infrastructure improvements and the continued reduction of renewable energy costs. Currently, wind, small hydro, and biomass are the most cost-competitive renewable options. Solar technologies, including concentrated solar power (CSP) and PV, are the least competitive but offer the greatest opportunity for growth because of the high potential. It therefore receives the most financial support in terms of government incentives.

Table 2-2. Power Generation Costs in India by Energy Source (2008)

\begin{tabular}{|l|l|l|}
\hline \multicolumn{1}{|c|}{ Energy Type } & $\begin{array}{c}\text { Electricity Generation Costs } \\
\text { in INR/kWh (USD/kWh) }\end{array}$ & \multicolumn{1}{|c|}{ Source } \\
\hline Coal & $1-2(0.02-0.04)$ & McKinsey - Powering India \\
\hline Nuclear & $2-3(0.04-0.06)$ & McKinsey - Powering India \\
\hline Large Hydro & $3-4(0.06-0.08)$ & McKinsey - Powering India \\
\hline Gas & $4-6(0.08-0.12)$ & McKinsey - Powering India \\
\hline Diesel & $10+(0.20+)$ & McKinsey - Powering India \\
\hline Wind (on-shore) & $3-4.5(0.06-0.09)$ & Industry experts \\
\hline Small Hydro & $3-4(0.06-0.08)$ & Industry experts \\
\hline Biomass & $4-5(0.06-0.10)$ & Industry experts \\
\hline Solar (CSP) & $10-15(0.20-0.30)$ & Industry experts \\
\hline Solar (PV) & $12-20(0.24-0.40)$ & Industry experts \\
\hline
\end{tabular}

\subsection{Renewable Energy Application in Industrial Use and Transportation}

A large percentage of renewable energy in India is covered under captive generation for industrial use. This is especially true in the wind market where $70 \%$ of electricity from wind projects is produced for direct consumption by large industrial facilities to mitigate the effect of frequent shortages of electricity from the national grid. Telecommunications companies are also looking toward renewable energy as they search for new solutions to power India's 250,000 telecom towers. Systems such as solar PV-based hybrid systems provide a less polluting alternative to diesel power, serve as a hedge against increasing diesel fuel prices, and help minimize the logistical challenges of transporting and storing diesel fuel at remote tower locations. ${ }^{67}$

\footnotetext{
${ }^{66}$ Over a period of 25 years.

${ }^{67}$ MNRE. Annual Report 2009-10. http://mnre.gov.in/annualreport/2009-10EN/index.htm. Accessed May 2010.
} 
For the last 2 years, solar cooling has been a buzzword in the industry. While its attraction in a country as sunny and hot as India is obvious, the technology is still under development and is not yet economically viable. There are, however, some demonstration sites such as the Muni Seva Ashram in Gujarat, which uses parabolic Scheffler-type dishes to supply a 100ton air-conditioning system. ${ }^{68}$

On the transportation front, there have been initiatives to switch to alternative transportation fuels such as compressed natural gas and electricity. The Reva, developed by the Maini Group, is India's - and one of the world's - first commercially available electric car. TATA and General Electric are also in the process of developing electric vehicles.

In addition, highly visible pilot projects are deployed to increase public interest in renewable energy technologies. The October 2010 Commonwealth Games in New Delhi are showcasing renewable energy for transportation and other uses including the utilization of at least 1,000 solar rickshaws, which use PV-powered motors for transporting athletes at the games. ${ }^{69}$ Also, a 1 MW PV plant will provide electricity for one of the stadiums at the games. ${ }^{70}$

Liquid biofuels, namely ethanol and biodiesel, are considered substitutes for petroleumderived transportation fuels. In India, ethanol is produced by the fermentation of molasses, a by-product of the sugar industry, but more advanced conversion technologies are under development, which will allow it to be made from more abundant lignocellulosic biomass resources such as forest and agricultural residues. Biodiesel production is currently very small, using non-edible oilseeds, waste oil, animal fat, and used cooking oil as feedstock. However, given the fact that India consumes more diesel than gasoline in the transportation sector, it is expected that the production of biodiesel and other biomass-derived diesel substitutes will grow over the next decade.

\subsection{National Renewable Energy Institutions and Policies}

In 1992, the Indian government established the world's first ministry committed solely to the development of renewable energy sources, The Ministry of Non-Conventional Energy Sources, which has since been renamed the Ministry of New and Renewable Energy. MNRE's role is to facilitate research, design, and development of new and renewable energy that can be deployed in the rural, urban, industrial, and commercial sectors. ${ }^{71}$ MNRE undertakes policymaking, planning, and promotion of renewable energy including financial incentives, creation of industrial capacity, technology research and development, intellectual property rights, human resource development, and international relations. ${ }^{72}$

MNRE's mission is to reduce India's dependence on imported oil, thereby improving the country's energy security supply; to increase clean power's share of the national energy mix; to increase the existing energy supply with a focus on improving access to clean energy; and to help new and renewable energy technologies to be cost-competitive. The ministry supports both on- and off-grid power generation from renewable sources including small hydro, wind,

\footnotetext{
${ }^{68}$ Muni Seva Ashram. http://munisevaashram.org/news6.html. Accessed July 2010.

${ }^{69}$ Economic Times. "1,000 Solar Rickshaws to Ferry Commonwealth Games Athletes.” 21 February 2010. http://economictimes.indiatimes.com/news/news-by-industry/et-cetera/1000-solar-rickshaws-to-ferryCommonwealth-Games-athletes/articleshow/5599685.cms. Accessed October 2010.

${ }^{70}$ Economic Times. "Comonwealth Games 2010 to be 'Solar Powered' by Reliance." 7 April 2010. http://economictimes.indiatimes.com/news/news-by-industry/et-cetera/CommonWealth-Games-2010-to-besolar-powered-by-Reliance/articleshow/5770329.cms. Accessed July 2010.

${ }^{71}$ MNRE. http://www.mnre.gov.in/. Accessed June 21, 2010.

${ }^{72}$ DIREC 2010. "About the MNRE." http://direc2010.gov.in/about.html. Accessed June 21, 2010.
} 
solar, biomass, and industrial/urban wastes. MNRE also has programs focused on rural areas, some of which supply electricity to remote villages and some promote and expand solar energy applications. MNRE has established research, design, and demonstration projects in new areas such as geothermal, hydrogen energy, and fuel cells. ${ }^{73}$ Moreover, MNRE supervises national institutions such as the Solar Energy Centre (SEC), the Centre for Wind Energy Technology (C-WET), and IREDA.

IREDA, established in 1987 as a Public Limited Government Company, extends financial assistance for renewable energy and energy efficiency projects. ${ }^{74}$ IREDA is registered as a non-banking financial company and arranges its resources through market borrowing and lines of credit from bilateral and multilateral lending agencies such as the Asian Development Bank (ADB), World Bank, the Nordic Investment Bank, Japan International Cooperation Agency, the French development agency AFD, and the German development bank KfW. IREDA provides term financing for renewable energy and energy efficiency projects including hydro energy, wind energy, bioenergy (biomass, biofuels, and waste-to-energy) and solar energy. A number of incentive schemes of MNRE are administered through IREDA.

There are a number of government institutions whose competence extends into the renewable energy sector. The Ministry of Power (MoP) deals with the planning of power supply, provision of political guidelines, investment decisions for government projects, training of experts, administration of laws for power generation from conventional sources, and power transmission and guidelines. MoP is responsible for the implementation of the Electricity Act 2003, the Energy Conservation Act of 2001, and JNNSM. ${ }^{75}$

Important government units like the CEA, the Central Electricity Regulatory Commission (CERC), the Power Finance Corporation (PFC), the PTC India Ltd., and the Rural Electrification Corporation fall under the purview of MoP.

- CEA's task is to develop a suitable energy policy for India and conduct planning and coordination tasks. It also completes the preliminary analysis for MoP on technical and economic issues. ${ }^{76}$

- CERC was established in 1998 under the Electricity Regulation Act as an independent, central regulation authority. It defines the tariffs for the public sector power producers and advises the government in matters of tariff and competition policy. The State Electricity Regulatory Commissions (SERCs), established at the level of the federal states, control the generation and distribution markets in their respective states. They monitor the quality of the services, tariffs, and fees. ${ }^{77}$

- PFC is responsible for tapping new sources of finance for investments in power projects in the public and private sectors. ${ }^{78}$

- PTC India Ltd., formerly called Power Trading Corporation of India Limited, was established in 1999 with a mandate to optimally utilize the existing resources to

\footnotetext{
${ }^{73}$ Government of India Planning Commission. "Eleventh Five Year Plan 2007-2012: Agriculture, Rural Development, Industry, Services, and Physical Infrastructure.” 2008; p. 385.

http://planningcommission.nic.in/plans/planrel/fiveyr/11th/11_v3/11th_vol3.pdf. Accessed April 2010.

${ }^{74}$ IREDA. "About IREDA-Background."

http://www.ireda.gov.in/homepage1.asp?parent category=1\&category=6. Accessed September 2010.

${ }^{75}$ MoP. http://www.powermin.nic.in//. Accessed July 2010.

${ }^{76}$ CEA. http://www.cea.nic.in//. Accessed September 2010.

${ }^{77}$ CERC. http://cercind.gov.in//. Accessed September 2010.

${ }^{78}$ PFC. http://www.pfc.gov.in///. Accessed September 2010.
} 
develop a full-fledged, efficient, and competitive power market to attract private investment in the Indian power sector and to encourage the trade of power with neighboring countries. ${ }^{79}$

- The Rural Electrification Corporation Ltd, established in 1969, is responsible for the financial support of all rural electrification programs including the large-scale Rajiv Gandhi Grameen Vidyutikaran Yojana (RGGVY), which aims to extend electricity to all rural households and households below the poverty line. ${ }^{80}$

The central government's renewable energy goals are included in several planning and policy documents. For example, the Planning Commission, established in 1950, is responsible for formulating five-year plans that prioritize the development and use of national resources. The Prime Minister's Council on Climate Change oversees India's NAPCC and periodically reviews key policy decisions affecting climate change. These plans are relevant for the renewable energy sector at the long-term, national policy level.

In addition to the cross-technology plans discussed in Sections 2.3.1-2.3.5, the Government of India has enacted technology-specific policies to support renewable energy deployment. These technology-specific policies are described in Chapters 3-7.

\subsubsection{Eleventh Plan}

India's five-year plans are developed under the leadership of the Planning Commission and describe a strategic plan of activities to be undertaken by the Government of India in support of priority objectives within the resources available. The Tenth Plan period ended in 2007, and the currently active Eleventh Plan ends in 2012. The Planning Commission hired a new and renewable energy working group to develop plans for renewable energy during the Eleventh Plan and prospective plans for the Twelfth and Thirteenth Plans. The group also looked into energy access programs using renewable technologies and identified necessary fiscal policies to support these programs and plans. As a result of the working group's proposals, the Eleventh Plan established the goal that $10 \%$ of power generation capacity shall be from renewable sources by 2012 and represent a 4\%-5\% share in the electricity mix. ${ }^{81}$ To achieve this, subsidies that promote investment without ensuring optimal performance (e.g., depreciation benefits) are to be phased out and replaced with incentives that emphasize performance (e.g., feed-in tariffs).

\subsubsection{Electricity Act 2003}

The Electricity Act 2003 has been a major step towards liberalizing the power market in India along the value chain, encouraging competition and attracting investment. It also mandates that the SERC establish requirements for the minimum purchase of electricity from renewable sources and allows penalties for non-compliance; SERCs are expected to use a RPO. Under the Act's Part VII Section 61(h), the promotion of cogeneration and electricity generation from renewable sources is identified as a consideration in the establishment of tariff regulations, allowing for the CERC to establish a preferential tariff for renewable energy. ${ }^{82}$ Further, the "open access" provision allows licensed renewable energy power

\footnotetext{
${ }^{79}$ PTC India Ltd. http://www.ptcindia.com//. Accessed September 2010.

${ }^{80}$ Rural Electrification Corporation Ltd. http://www.recindia.nic.in//. Accessed September 2010.

${ }^{81}$ Government of India Planning Commission. "Eleventh Five Year Plan 2007-2012: Agriculture, Rural Development, Industry, Services, and Physical Infrastructure." 2008.

http://planningcommission.nic.in/plans/planrel/fiveyr/11th/11 v3/11th vol3.pdf. Accessed April 2010.

${ }^{82}$ MoP. "The Electricity Act, 2003."

http://www.powermin.nic.in/acts notification/electricity act2003/pdf/The $\% 20$ Electricity $\% 20$ Act_2003.pdf. Accessed October 2010.
} 
generators access to transmission lines and distribution systems and only requires that the generators pay a wheeling fee for use of the transmission lines and a fee to the load dispatch center. $^{83}$

\subsubsection{National Electricity Policy 2005}

NEP stipulates the need for increasing the share of electricity from non-conventional sources and allows for the SERCs to establish a preferential tariff for electricity generated from renewable sources to enable them to be cost-competitive. ${ }^{84}$ Section 5.12 .3 of NEP encourages the development of cogeneration facilities and allows for SERCs to promote arrangements between cogenerators and distribution companies interested in purchasing excess electricity through a competitive bidding process.

\subsubsection{National Tariff Policy 2006}

The National Tariff Policy, announced in January 2006, mandates each SERC to specify a RPO with distribution companies in a time-bound manner. Again, these purchases are to be made through a competitive bidding process. The objective of this policy is to enable renewable energy technologies to compete with conventional sources. Section 6.4 of the National Tariff Policy calls for the relevant commission to establish preferential tariffs with distribution companies for the purchase of electricity from non-conventional technologies. ${ }^{85}$

\subsubsection{Rural Electrification Programs}

RGGVY was launched by the central government in 2005 with the goal of extending electricity to all rural households and to households below the poverty line. ${ }^{86}$ Under this program, $90 \%$ of the capital costs are subsidized by the central government. As of 2009 , only $44 \%$ of Indian households had been electrified. ${ }^{87}$ To electrify some of these villages and hamlets, the government has used distributed renewable as well as non-renewable energy sources. During the Tenth Plan, renewable energy sources were tapped to electrify approximately 5,000 villages and hamlets with the majority of communities being served by solar energy. For a more detailed description, see Chapter 7.

\subsection{Governance and Institutional Arrangement of Renewable Energy}

The liberalization and reform process initiated in 1991 with the division of the energy ministry into MoP, the Ministry of Coal, and MNRE has led to large-scale changes in the governance structure of the power market. Today, along with the traditional central government and state-level actors, there is also an increasingly active private sector at most of the points along the value chain, especially in generation, transmission, and power trading (see Table 2-3). Private interest remains low in the distribution network.

\footnotetext{
${ }^{83}$ Baker \& McKenzie. (2008). "Identifying Optimal Legal Frameworks for Renewable Energy in India." Renewable Energy and International Law. Asia-Pacific Partnership. p. 13. http://www.asiapacificpartnership.org/pdf/REDG-0609\%2520Final\%2520Report_India_pdf\&sa=U\&ei=BgC3TITPBcXBswaPoZGPCQ\&ved=0CBMQFjAA\&usg= AFQjCNGkQ6XCHcmHJkEc5rV5MI1384uEaw. Accessed October 2010.

${ }^{84}$ Government of India MoP National Electricity Policy. "The Gazette of India: Extraordinary Part I - Section 1." http://www.powermin.nic.in/whats new/national_electricity policy.htm. Accessed September 2010.

${ }^{85}$ Government of India MoP. "Tariff Policy.” http://www.powermin.nic.in/whats_new/pdf/Tariff_Policy.pdf. Accessed May 2010.

${ }^{86}$ Government of India Planning Commission. "Eleventh Five Year Plan 2007-2012: Agriculture, Rural Development, Industry, Services, and Physical Infrastructure." 2008. http://planningcommission.nic.in/plans/planrel/fiveyr/11th/11_v3/11th_vol3.pdf. Accessed April 2010. ${ }^{87}$ REEEP. "Policy and Regulatory Review-Special Report on India and Indian States." Renewable Energy \& Energy Efficiency Partnership, 2009. http://www.reeep.org/file_upload/296 tmpphpdxs0Zs.pdf. Accessed October 2010.
} 
Table 2-3. Actors in the Indian Power Market Along the Value-creation Chain ${ }^{88}$

\begin{tabular}{|c|c|c|c|c|}
\hline & \multicolumn{2}{|c|}{ Central Government } & State & Private \\
\hline Policy & \multicolumn{2}{|c|}{ MoP, MNRE } & State governments & - \\
\hline Planning & \multicolumn{2}{|l|}{ CEA } & SEB & - \\
\hline Regulation & \multicolumn{2}{|l|}{ CERC } & SERCs & - \\
\hline Generation & \multicolumn{2}{|c|}{ National generation utilities } & State generation utilities & $\begin{array}{l}\text { Independent power } \\
\text { producers }\end{array}$ \\
\hline Transmission & - & \multirow{2}{*}{$\begin{array}{l}\text { Power Grid } \\
\text { Corporation } \\
\text { of India } \\
\text { Limited }\end{array}$} & State transmission utilities & $\begin{array}{l}\text { Increasing number of } \\
\text { private service providers }\end{array}$ \\
\hline Execution & $\begin{array}{l}\text { Regional } \\
\text { load } \\
\text { dispatch } \\
\text { centers }\end{array}$ & & State load dispatch centers & \\
\hline Distribution & \multicolumn{2}{|l|}{-} & State distribution utilities & $\begin{array}{l}\text { Small number of private } \\
\text { service providers }\end{array}$ \\
\hline Trade & \multicolumn{2}{|c|}{$\begin{array}{l}\text { PTC India Ltd. } \\
\text { Licensee }\end{array}$} & Licensee & Licensee \\
\hline Law & \multicolumn{4}{|c|}{ Appeal tribunal } \\
\hline
\end{tabular}

As of yet there is no overarching renewable energy law governing all states. Instead, there are separate initiatives by the central and state governments. For instance, JNNSM is an initiative of the central government, whereas RPOs and RECs come under state jurisdiction. For specific technologies, central government policies and guidelines have been implemented to different degrees by individual states, which can result in inconsistencies between states. ${ }^{89}$ For example, states have different policies regarding which entity (developer, power purchaser, or transmission and distribution company) is required to finance the extension of transmission and distribution lines when generation facilities are developed beyond the reach of the current grid. States also have different regulations regarding technical standards such as mandating the location of the meter, which affects the measurement of the amount of energy that is sold to the grid. ${ }^{90}$

\subsection{Grid Connection and Status Overview}

In March 2009, the Indian power network had a total length of 7.49 million circuit kilometers $(\mathrm{ckm}) .{ }^{91}$ In comparison to the power generation sector, investments into the transmission and distribution networks have been lower in recent years. Nevertheless, the transmission network has improved considerably. The distribution network, however, remains in a poor

\footnotetext{
${ }^{88}$ Gtz. "Energiemarkt Indien 2010.” p. 48. http://www.sciencerepository.org/in_documents/IN1096.pdf. Accessed October 2010.

${ }^{89}$ Baker \& McKenzie. "Identifying Optimal Legal Frameworks for Renewable Energy in India." Renewable Energy and International Law. Asia-Pacific Partnership, 2008. http://www.asiapacificpartnership.org/pdf/REDG-0609\%2520Final\%2520Report India .pdf\&sa=U\&ei=BgC3TITPBcXBswaPoZGPCQ\&ved=0CBMQFjAA\&usg= AFQjCNGkQ6XCHcmHJkEc5rV5MI1384uEaw. Accessed October 2010.

${ }^{90}$ REEEP. "Policy and Regulatory Review-Special Report on India and Indian States." http://www.reep.org/file upload/296 tmpphpdxs0Zs.pdf. Accessed October 2010.

${ }^{91}$ CEA. "Growth of Electricity Sector in India from 1947-2009." New Delhi: CEA, 2009.; pp. 3-4.
} 
state. In the ongoing Eleventh Plan, the high-voltage network is to be extended by around $95,000 \mathrm{ckm}$ to a capacity of more than 178,000 mega volt amperes (MVA). In the lowvoltage area, an additional 3,253,773 ckm and a capacity of 214,000 MVA are to be added. Another extremely important task is the "Power for All by 2012 " mission, ${ }^{92}$ declared by the Government of India - the ambitious goal of providing power to all Indian villages by 2012, to a large extent through grid access.

\subsection{Renewable Purchase Obligations and Renewable Energy Credits 2.6.1 Renewable Purchase Obligations}

Section 86(1)(e) of the Electricity Act 2003 requires that the state commissions specify RPOs for the obligated entities. It says, "The State Commission shall discharge the following functions, namely: ... promote cogeneration and generation of electricity from renewable sources of energy by providing suitable measures for connectivity with the grid and sale of electricity to any person, and also specify, for purchase of electricity from such sources, a percentage of the total consumption of electricity in the area of a distribution license. ${ }^{.93} \mathrm{In}$ pursuance of this policy, the National Tariff Policy mandates that each SERC specify RPOs by distribution licensees in a time-bound manner. As of April 2010, 18 states have established RPOs or have draft regulations under consideration (see Table 2-4) with RPO requirements ranging from $1 \%$ to $15 \%$ of total electricity generation.

Table 2-4. State RPOs ${ }^{94}$

\begin{tabular}{|l|l|l|l|}
\hline \multicolumn{1}{|c|}{ State } & \multicolumn{1}{|c|}{$\begin{array}{c}\text { 2009-2010 } \\
\text { RPO }\end{array}$} & $\begin{array}{l}\text { Out Year RPO } \\
\text { (if designated) }\end{array}$ & \multicolumn{1}{c|}{ Notes } \\
\hline Andhra Pradesh & $5 \%$ & $\begin{array}{l}5 \% \text { in each year from 2004-2008, no RPO } \\
\text { requirements specified thereafter }\end{array}$ \\
\hline Assam & $5 \%$ & $\begin{array}{l}2015-2016 \\
15 \%\end{array}$ & Draft regulation currently under consideration \\
\hline Chhattisgarh & $\begin{array}{l}\text { Biomass 5\%, } \\
\text { Small Hydro } \\
\text { Others 2\% }\end{array}$ & & $\begin{array}{l}\text { Same percentages for each year from 2007-2010, } \\
\text { no RPO requirements specified thereafter }\end{array}$ \\
\hline Delhi & $1 \%$ & $\begin{array}{l}\text { 1\% RPO for four separate utilities (NDPL, BYPL, } \\
\text { BRPL, NDMC) from 2006-2010, no RPO } \\
\text { requirements specified thereafter }\end{array}$ \\
\hline Gujarat & $2 \%$ & $\begin{array}{l}2012-2013 \\
7 \%\end{array}$ & $\begin{array}{l}2010-2011 \\
10 \%\end{array}$ \\
\hline Haryana & $10 \%$ & & $\begin{array}{l}\text { Draft regulation under consideration to establish an } \\
\text { RPO of 5\% for each year from 2010-2013 }\end{array}$ \\
\hline Jharkhand & & $\begin{array}{l}\text { The RPO percentage depends on the distribution } \\
\text { company with a maximum set at 20\% }\end{array}$ \\
\hline Karnataka & $7 \%-10 \%$ & $7 \%-10 \%$ &
\end{tabular}

\footnotetext{
${ }^{92}$ MoP. "Overview.” http://www.powermin.nic.in/transmission/transmission overview.htm. Accessed September 2010. "Power for All by 2012." http://www.powermin.nic.in/indian_electricity_scenario/power_for_all_target.htm. Accessed September 2010 ${ }^{93}$ Electricity Act 2003. Section 86(e). http://www.sciencerepository.org/in documents/IN1096.pdf. Accessed October 2010.

${ }^{94}$ Shah, S.R. "Feed-in Tariff \& Renewable Purchase Obligation for Distribution Companies." Presented to the Associated Chambers of Commerce and Industry of India at the Conference on Mainstreaming Green EnergyWind, Biomass \& Solar, Chennai. http://www.assocham.org/events/recent/showevent.php?id=426. April 29, 2010.
} 


\begin{tabular}{|c|c|c|c|}
\hline Kerala & $\begin{array}{l}\text { Wind } 2 \%, \\
\text { Small Hydro } \\
2 \% \text {, } \\
\text { Others } 1 \%\end{array}$ & & $\begin{array}{l}5 \% \text { each year from } 2006-2009, \text { no RPO } \\
\text { requirements specified thereafter }\end{array}$ \\
\hline Madhya Pradesh & $\begin{array}{l}\text { Wind } 6 \% \text {, } \\
\text { Biomass } 2 \% \text {, } \\
\text { Cogen } 2 \% \text {, } \\
\text { Others } 2 \%\end{array}$ & $\begin{array}{l}2011-2012 \\
12 \%\end{array}$ & \\
\hline Maharashtra & $5 \%$ & & $\begin{array}{l}\text { RPO specified from } 2005-2009 \text {, no RPO } \\
\text { requirements specified thereafter; draft regulation } \\
\text { currently under consideration to increase the RPO } \\
\text { from } 6 \% \text { in } 2010-2011 \text { to } 10 \% \text { in } 2015-2016 \text { and to } \\
\text { include a solar set aside }\end{array}$ \\
\hline Orissa & $5 \%$ & $\begin{array}{l}2015-2016 \\
8 \%(0.5 \% \\
\text { increase/year) }\end{array}$ & Draft regulation currently under consideration \\
\hline Punjab & $3 \%$ & $\begin{array}{l}2010-2011 \\
4 \%\end{array}$ & \\
\hline Rajasthan & $\begin{array}{l}\text { Wind } 6.75 \% \text {, } \\
\text { Biomass } 1.75 \% \text {, } \\
\text { Others } 8.5 \%\end{array}$ & $\begin{array}{l}\text { 2010-2011 } \\
\text { Wind } 7.5 \% \\
\text { Biomass } 2 \% \text {, } \\
\text { Others } 9.5 \%\end{array}$ & \\
\hline Tamil Nadu & $13 \%$ & $\begin{array}{l}2010-2011 \\
14 \%\end{array}$ & \\
\hline Uttarakhand & $9 \%$ & $\begin{array}{l}2010-2011 \\
10 \%\end{array}$ & \\
\hline West Bengal & $7 \%-9 \%$ & $\begin{array}{l}2010-2011 \\
10 \% \text { for all utilities }\end{array}$ & $\begin{array}{l}\text { RPO depends on the utility until } 2010 \text { when all are } \\
\text { required to meet the } 10 \% \text { goal }\end{array}$ \\
\hline
\end{tabular}

\subsubsection{Tradable Renewable Energy Credits}

Naturally, the availability of renewable energy sources differs across India. In some states, such as Delhi, the potential for harnessing renewable energy compared to the demand for energy is very small. In other states, such as Tamil Nadu for wind, Rajasthan for solar, or Himachal Pradesh for hydro, it is very high. This offers opportunities for inter-state trading in the form of RECs.

Such trade allows for more economically efficient development of renewable energy throughout the country as distribution licensees in states with limited resources can purchase RECs associated with renewable generation in other states where it is less expensive to develop renewable energy projects. In this way, each state's RPO can be met in the most economically efficient manner. In January 2010, CERC announced the terms and conditions for a tradable REC program as follows:

- "There will be a central agency, to be designated by CERC, for registering RE generators participating in the scheme.

- The renewable energy generators will have two options [Shown in Figure 2-1]: either sell the renewable energy at a preferential tariff fixed by the concerned Electricity Regulatory Commission, or sell the electricity generation and environmental attributes associated with RE generation separately. 
- On choosing the second option, the environmental attributes can be exchanged in the form of REC. Price of the electricity component would be equivalent to the weighted average power purchase cost to the distribution company, including short-term power purchase but excluding renewable power purchase cost.

- The central agency will issue the REC to renewable energy generators.

- The value of one REC will be equivalent to $1 \mathrm{MWh}$ of electricity delivered to the grid from renewable energy sources.

- The REC will be exchanged only in the power exchanges approved by CERC within the band of a floor price and a forbearance (ceiling) price to be determined by CERC from time to time."

CERC issued an amendment to the terms in September 2010 clarifying participation of captive generation plants and restricting participation of any generator terminating an existing PPA to sell power under the REC scheme. ${ }^{96}$ The two paths under which renewable power will be sold under the REC program are illustrated in Figure 2-1.

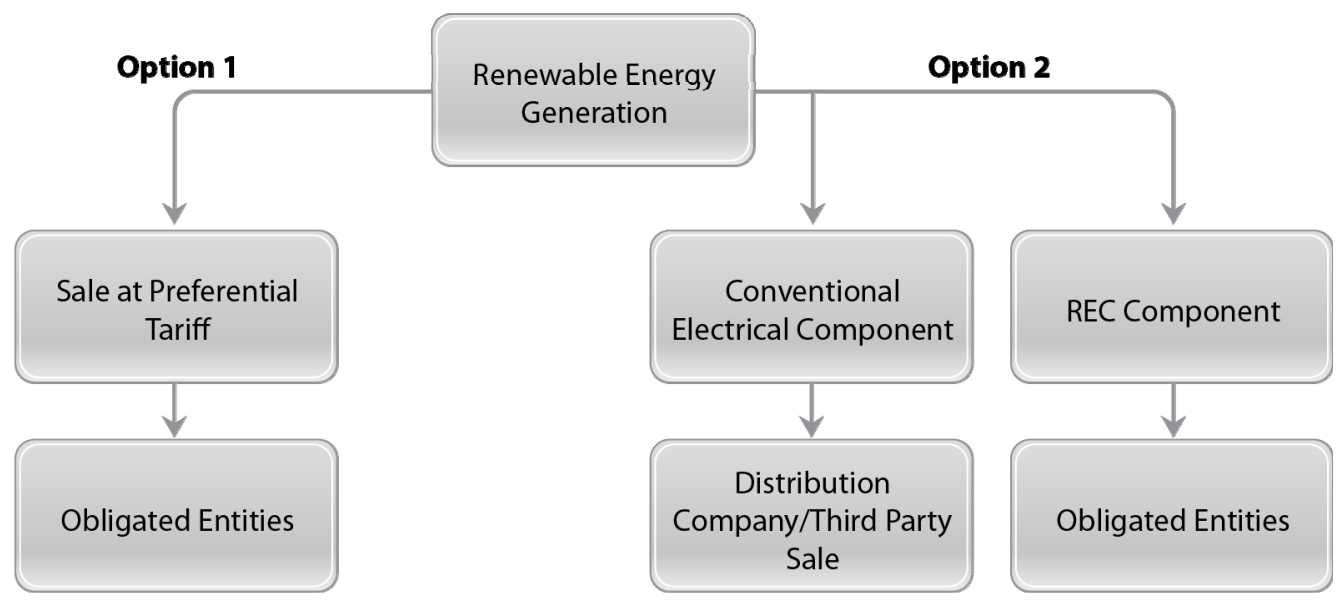

Figure 2-1. Route for sale of renewable energy generation

\footnotetext{
${ }^{95}$ CERC. "CERC Announces Renewable Energy Certificate (REC) Regulation-A Step Forward for Green Energy Promotion.” Press Release, 18 January 2010.

${ }^{96}$ CERC. "REC Amendment Regulation." http://www.cercind.gov.in/Regulations/REC_Amemdment_Regulation_29 9 2010.pdf. Accessed October 2010.
} 


\section{Wind Power}

\section{Chapter Overview}

India has been a pioneer in the commercial use of wind energy in Asia since the 1990s. In 2009, India had the fifth largest installed wind capacity globally, only behind the United States, China, Germany, and Spain. During that year, India added 1,338 $\mathrm{MW}^{97}$ of wind capacity for a total installed capacity of $10,925 \mathrm{MW}$. This represented a $14 \%$ annual growth rate and contributed $3.5 \%$ to the global wind market. ${ }^{98}$ The most recent data available at the time of this writing show that India's wind capacity totalled 12,009 MW at the end of June 2010 , which represented $70 \%$ of India's total renewable energy capacity. ${ }^{99}$ India's robust domestic market has transformed the Indian wind industry into a significant global player.

The success of the Indian wind market can be attributed to the quality of the wind resource and to government incentives, which became available early on as the global wind industry began to grow. Indian company Suzlon is the market-leader in wind power in Asia and the third largest manufacturer of wind turbines in the world. In combination with its German subsidiary REpower, Suzlon has a world market share of $12.3 \%$ in installed new capacity. ${ }^{100}$

\subsection{Wind Power Potential}

The C-WET resource assessment program has estimated the potential for wind installation for nine states, as shown in Table 3-1. The estimates are based on the assumption that $1 \%$ of each state's land area is available for development and that each megawatt of wind capacity requires 12 ha of land. The assessment shows that India's total wind potential is 48,561 MW, with Karnataka, Gujarat, and Andhra Pradesh as the leading states. ${ }^{101}$

Table 3-1. Wind Potential for Nine Indian States (C-WET) ${ }^{102}$

\begin{tabular}{|lr|}
\hline State & Wind Power Potential (MW) \\
\hline \hline Andhra Pradesh & 8,968 \\
Gujarat & 10,645 \\
Karnataka & 11,531 \\
Kerala & 1,171 \\
Madhya Pradesh & 1,019 \\
Maharashtra & 4,584 \\
Orissa & 255 \\
Rajasthan & 4,858 \\
Tamil Nadu & 5,530 \\
Total & $\mathbf{4 8 , 5 6 1}$ \\
\hline
\end{tabular}

\footnotetext{
${ }^{97}$ The megawatts used throughout this chapter to represent wind power capacity represent wind turbine nameplate capacities. This is a convenient way to represent wind turbine sizes and the capacity of wind installations.

${ }^{98}$ World Wind Energy Association. "World Wind Energy Report 2009." http://www.wwindea.org/home/images/stories/worldwindenergyreport2009_s.pdf. Accessed October 2010.

${ }^{99}$ MNRE. “Achievements in New and Renewable Energy.” http://mnre.gov.in. Accessed August 2010.

${ }^{100}$ Suzlon. http://www.suzlon.com. Accessed August 2010.

${ }^{101}$ Indian Wind Energy Association (INWEA). "Wind Energy Programme in India." http://www.inwea.org/aboutwindenergy.htm. Accessed August 2010.

${ }^{102}$ MNRE. "Wind Power Potential in India." http://mnre.gov.in/wpp.htm. Accessed August 2010.
} 
C-WET has also published a map of wind resource distribution across India (see Figure 3-1). This map shows large areas suitable for wind power development with estimated wind power density greater than $200 \mathrm{~W} / \mathrm{m}^{2}$ at a height of $50 \mathrm{~m}$ above the ground. Further assessment in the north, which the map shows as having exceptionally good resource, could substantially increase the total estimated wind potential for India, although projects in these parts could be constrained by additional development costs due to the remoteness of these areas. There has been no systematic assessment of offshore wind power potential to date.

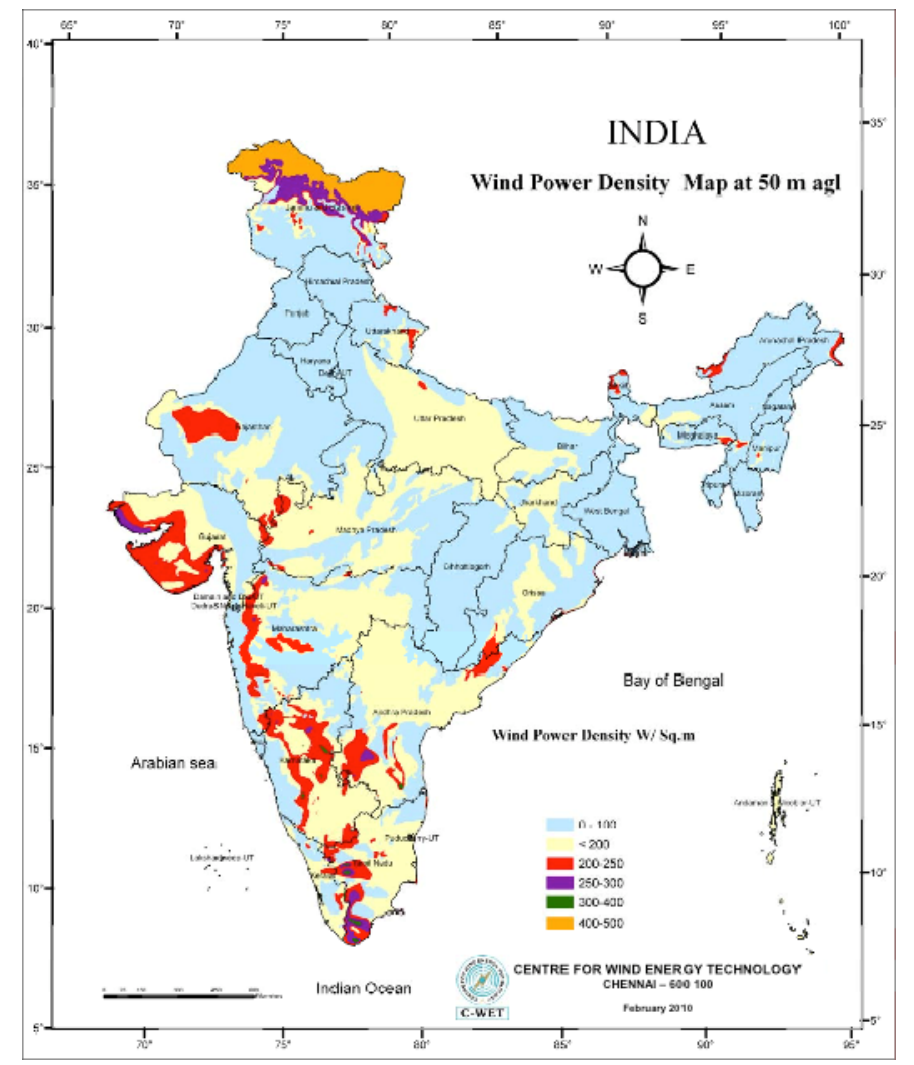

Figure 3-1. Wind power density at $50 \mathrm{~m}$ above the ground for India ${ }^{103}$

The capacity potential of 48,561 MW estimated by C-WET and officially accepted by MNRE is lower than those of industry associations. The Indian Wind Turbine Manufacturers Association argues that by looking at higher heights above the ground to match 55-75 m turbine hub heights of the latest turbines and taking into account higher conversion efficiencies due to recent improvements in wind technology, the wind potential in India is closer to between 65,000 and 70,000 MW. ${ }^{104}$ The Global Wind Energy Council (GWEC) outlines three different wind growth scenarios and their associated installed capacity estimates for 2030: reference, moderate, and advanced. The reference scenario follows the International Energy Agency (IEA) World Energy Outlook 2007, the moderate scenario takes into account all policy actions in planning stages or beyond, and the advanced scenario assumes that all industry-supported policy actions are implemented. All three GWEC scenarios assume smaller wind turbines will be replaced with modern models, average turbine capacities will increase, capacity factors will increase from improved technologies and sitings, and capital costs will decrease. The advanced scenario estimate is much higher

\footnotetext{
${ }^{103}$ C-WET. "WPD Map.” http://www.cwet.tn.nic.in/html/departments_wpdmap.html. Accessed August 2010.

${ }^{104}$ Indian Wind Turbine Manufacturers Association. "Indian Wind Energy and Economy." http://www.indianwindpower.com/iw energy economy.php. Accessed August 2010.
} 
than any of the other estimates at 241,349 MW installed by 2030, the moderate scenario is $142,219 \mathrm{MW}$, and the reference scenario estimate is $27,325 \mathrm{MW} .^{105}$

\subsection{Installed Capacity and Power Generation}

In March 2006, India had approximately 5,300 MW of installed wind capacity. Between 2006 and 2009, the annual rate of wind capacity additions decreased, as shown in Figure 3-2. ${ }^{106}$ In certain states, however, as new markets opened up, growth rates were above average. For example, between 2008 and 2009, annual growth rates of installations were $37 \%$ in Rajasthan, 33\% in Karnataka, and 25\% in Gujarat, while the average across India was $17 \%$.

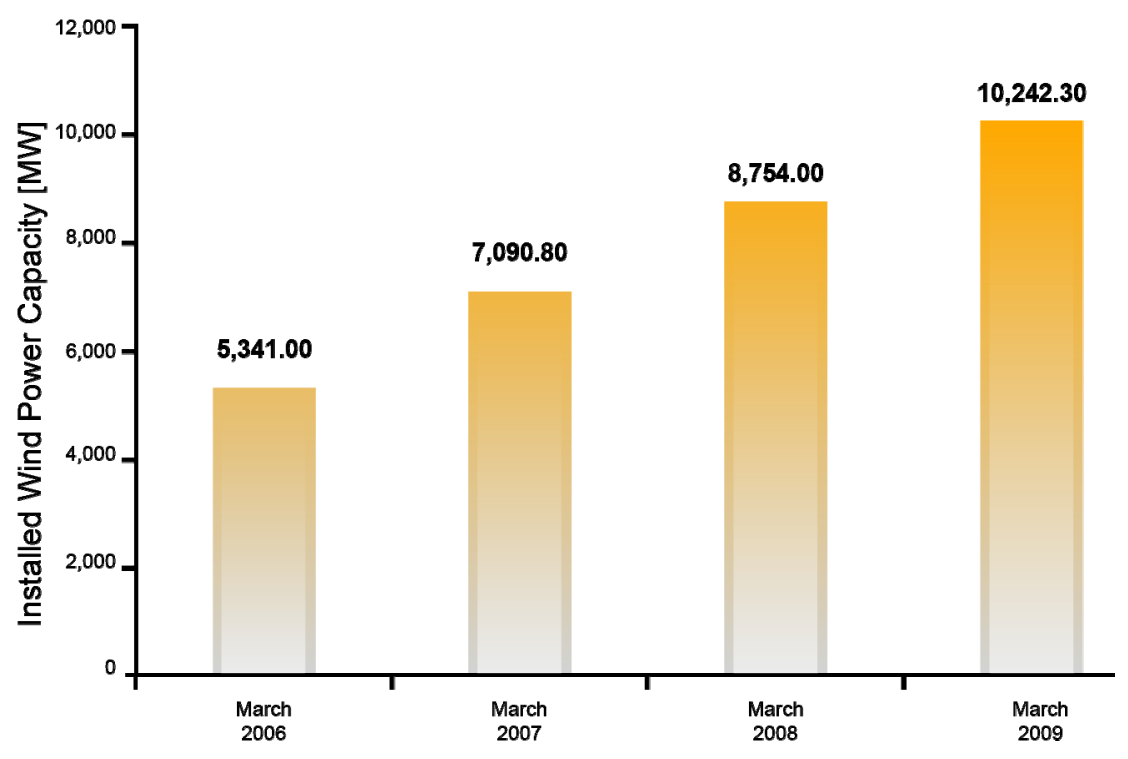

Figure 3-2. Growth of installed wind power capacity in India ${ }^{107}$

India's capacity additions of more than 3,000 MW between 2007 and 2009 are shown by state in Table 3-2. The largest gains were seen in Tamil Nadu (884 MW) and Gujarat (837 MW). Tamil Nadu in south India has set itself apart from the other states with a total installed capacity of 4,596 MW, or $42 \%$ of India's total installed capacity, as of the end of 2009. ${ }^{108}$ At the end of June 2010, India's installed wind capacity totalled 12,009 MW, representing $70 \%$ of India's total renewable energy capacity. ${ }^{10}$

\footnotetext{
105 GWEC. "Indian Wind Energy Outlook 2009."

http://www.indianwindpower.com/pdf/GWEO_A4_2008_India_LowRes.pdf. Accessed August 2010.

${ }^{106}$ GWEC. Global Wind Report 2008.

http://www.gwec.net/fileadmin/documents/Global\%20Wind\%202008\%20Report.pdf. Accessed August 2010.

${ }_{107}^{107}$ Indian Wind Energy Association. http://www.inwea.org/. Accessed August 2010.

${ }^{108}$ MNRE. Annual Report 2009-10. http://mnre.gov.in/annualreport/2009-10EN/index.htm. Accessed August 2010.

${ }^{109}$ MNRE. “Achievements in New and Renewable Energy.” http://mnre.gov.in. Accessed September 2010.
} 
Table 3-2. Wind Capacity Additions by State

\begin{tabular}{|c|c|c|c|}
\hline State & $\begin{array}{c}\text { Total Installed } \\
\text { Wind Capacity } \\
2007 \text { (MW) }{ }^{110} \\
\end{array}$ & $\begin{array}{c}\text { Total Installed } \\
\text { Wind Capacity } \\
2009(\mathrm{MW})^{111} \\
\end{array}$ & $\begin{array}{l}\text { Wind Capacity } \\
\text { Additions } \\
\text { 2008-2009 (MW) }\end{array}$ \\
\hline Andhra Pradesh & 123 & 123 & 0 \\
\hline Gujarat & 875 & 1,712 & 837 \\
\hline Karnataka & 917 & 1,391 & 474 \\
\hline Kerala & 2 & 27 & 25 \\
\hline Madhya Pradesh & 70 & 213 & 143 \\
\hline Maharashtra & 1,646 & 2,004 & 358 \\
\hline Rajasthan & 496 & 855 & 359 \\
\hline Tamil Nadu & 3,712 & 4,596 & 884 \\
\hline Others & 4 & 4 & 0 \\
\hline Total & 7,845 & 10,925 & 3,080 \\
\hline
\end{tabular}

In terms of electricity supply, in 2007, wind projects supplied 11,653 GWh to Indian consumers, representing a $1.45 \%$ share of the total electricity produced in India that year. ${ }^{112}$ Based on the 2007 installed capacity of 7,845 MW shown in Table 3-2, this equates to a capacity factor of approximately $17.0 \%(11,653 \mathrm{GWh} / \mathrm{yr} \div 7.845 \mathrm{GW} \div 8760 \mathrm{~h} / \mathrm{yr} \times 100 \%)$. This capacity factor is a rough indication of the average conversion efficiency of wind power plants: higher capacity factors represent more efficient plants. For comparison, India's average capacity factor in 2007 was slightly higher than China's in 2007 at $16.6 \%$ but significantly lower than Germany (20.4\%), Spain (20.7\%), and the United States $(23.5 \%){ }^{113}$

\subsection{Existing Policies, Measures, and Local Regulations}

One provision of the Electricity Act of 2003 allowed turbine manufacturers to provide complete build-operate-manage wind solutions. As manufacturers, their primary interest was in installing as many new wind projects as possible to maximize turbine sales rather than in maximizing electricity generation of individual wind plants. Many other investors made similar decisions, choosing to install as much capacity as possible to profit from taxdepreciation benefits with little regard to how well their wind plants would perform over the long term.

Newer policies, such as GBIs and RPOs, encourage independent power producers and private investors to establish large-scale, commercial wind plants that enable wind to be a more significant part of the power mix. Based on experiences in other countries, both GBIs and RPOs are generally considered to be positive steps towards encouraging the development of wind power. These can lead to developer investment in more comprehensive resource assessments at the project site and a more optimized plant design. More independent power producers may enter India's wind market, turbine sizes and tower heights are increasing, and

\footnotetext{
${ }^{110}$ MNRE. Annual Report 2008-09, http://mnre.gov.in/annualreport/2008-09EN/index.htm. Accessed August 2010 .

${ }^{111}$ MNRE. Annual Report 2009-10. http://mnre.gov.in/annualreport/2009-10EN/index.htm. Accessed August 2010.

${ }^{112}$ IEA. "Electricity/Heat in India in 2007."

http://www.iea.org/stats/electricitydata.asp?COUNTRY_CODE=IN. Accessed August 2010.

${ }^{113}$ The capacity factors for China, Germany, Spain, and the United States were calculated using IEA's estimated wind power generation for 2007 (http://www.iea.org/stats/prodresult.asp?PRODUCT=Renewables; accessed August 2010), and the 2007 installed capacity values from GWEC's Global Wind 2007 report (http://www.gwec.net/index.php?id=90; accessed August 2010). GWEC's installed capacity value for India in 2007 was $8,000 \mathrm{MW}$; using this figure yields an estimated capacity factor of $16.6 \%$.
} 
turbine technology is continuing to improve, all of which may contribute to higher capacity factors for future wind plants in India. However, until there is a long-term guarantee for GBIs beyond 2012 and an enforcement of the RPO targets, there is unlikely to be real movement in the market. ${ }^{114}$

A project developer can currently choose between the central government's accelerated depreciation or GBIs; the preference cannot be changed once the choice has been made. ${ }^{115}$

\subsubsection{State-level Renewable Energy Preferential Tariffs}

In 2003, SERCs were given the right to set preferential renewable energy tariffs based on guidelines stipulated by CERC. Although several states have followed through, these tariffs are insufficient to drive further development in wind. However, the state-level GBIs can be used in conjunction with the central-level incentives (either accelerated depreciation or GBIs) to make projects more financially attractive to developers. ${ }^{116}$

For 2009-2010, CERC established a preferential tariff band for wind energy projects ranging from INR 3.75/kWh (USD 0.68/kWh) to INR 5.63/kWh (USD 1.01/kWh), depending on the project size. ${ }^{117}$ State wind energy preferential tariffs range from INR $3.14 / \mathrm{kWh}$ (USD $0.57 / \mathrm{kWh}$ ) in Kerala to INR 4.08/kWh (USD 0.73/kWh) in Haryana. ${ }^{118}$ Other states that have established feed-in tariffs include Maharashtra, Andhra Pradesh, Madhya Pradesh, Karnataka, Tamil Nadu, and West Bengal; all states have caps ranging from $50 \mathrm{MW}$ to $500 \mathrm{MW} .{ }^{119}$ The tariff conditions vary by state as well; some are fixed for a set number of years while the tariffs in other states are reduced or escalated during those years.

\subsubsection{Accelerated Depreciation}

In the past, the main incentive for developing wind power projects was accelerated depreciation. This tax benefit allows projects to deduct up to $80 \%$ of the value of wind power equipment during the first year of the project's operation. Investors are then given tax exemption status for up to 10 years. ${ }^{120}$ Wind power producers receiving accelerated depreciation benefits must register with and provide generation data to IREDA and are not eligible to receive the more recent GBIs. ${ }^{121}$

\subsubsection{Indirect Tax Benefits}

Indirect tax benefits included exemptions or concessions on the excise duty and a reduction in customs duty for certain wind power equipment. ${ }^{122}$ Wind-powered electricity generators and

\footnotetext{
${ }^{114}$ MNRE. "Unleashing the Wind Tiger.” Renewable Energy World; May 2010.

${ }^{115}$ MNRE. "Generation Based Incentives (GBI) for Wind Power Projects.” http://www.mnre.gov.in/gbischeme.htm. Accessed August 2010.

${ }^{116}$ MNRE. “Unleashing the Wind Tiger.” Renewable Energy World; May 2010.

${ }^{117}$ CERC. "Tariff Order." http://www.cercind.gov.in/2009/November09/284-2009 final 3rdDecember09.pdf. Accessed September 2010.

${ }^{118}$ Shah, S.R. "Feed-in Tariff \& Renewable Purchase Obligation for Distribution Companies." Presented to the Associated Chambers of Commerce and Industry of India at the Conference on Mainstreaming Green EnergyWind, Biomass \& Solar, Chennai. http://www.assocham.org/events/recent/showevent.php?id=426. April 29, 2010 .

${ }^{119}$ MNRE. "Unleashing the Wind Tiger." Renewable Energy World; May 2010.

${ }^{120}$ IREDA. “Central Incentives.” http://www.ireda.in/incentives.asp. Accessed August 2010

${ }^{121}$ MNRE. "Generation Based Incentives (GBI) for Wind Power Projects.” http://www.mnre.gov.in/gbischeme.htm. Accessed August 2010.

${ }^{122}$ Shah, S.R. "Feed-in Tariff \& Renewable Purchase Obligation for Distribution Companies." Presented to the Associated Chambers of Commerce and Industry of India at the Conference on Mainstreaming Green EnergyWind, Biomass \& Solar, Chennai. http://www.assocham.org/events/recent/showevent.php?id=426. April 29, 2010
} 
components, as well as water-pumping wind mills, wind aero-generators, and battery chargers, are exempt from excise duties. Indirect tax benefits for manufacturers of specific wind energy parts vary from $5 \%-25 \%$ depending on the component. ${ }^{123}$

\subsubsection{Central-level Generation-based Incentives}

Offered by the central government since June 2008 and administered by IREDA, the GBI for wind is available for independent power producers with a minimum installed capacity of 5 MW. As of December 2009, the GBI is set at INR 0.50/kWh (USD 0.01/kWh) of gridconnected electricity for a minimum of 4 years and a maximum of 10 years, up to a maximum of INR 6.2 million (USD 140,000) per MW. The scheme will deploy a total of INR 3.8 billion (USD 81 million) until 2012 and aims to incentivize capacity additions of 4,000 MW. Wind power producers receiving a GBI must register with and provide generation data to IREDA. ${ }^{124}$ The GBI is offered in addition to SERC's state preferential renewable energy tariffs. However, IPPs using GBIs cannot also take advantage of accelerated depreciation benefits. ${ }^{125}$ The GBI program will be reviewed at the end of the Eleventh Plan and revised as deemed appropriate. As of October 2010, 30 projects had been registered under this scheme with over $200 \mathrm{MW}$ commissioned. ${ }^{126}$

\subsubsection{Renewable Purchase Obligations}

As discussed in Chapter 2, several states have implemented RPOs with a requirement that renewable energy supplies between $1 \%$ and $15 \%$ of total electricity. The impact of the RPOs on wind development may depend on the penalties and enforcement of the targets as well as an effective REC market to promote development of areas of the country with the most abundant wind resources.

\subsection{Investment Flows and Industrial Trends}

The cost of producing wind turbines is lower in India than in other countries as a result of lower labor and production costs relative to other countries producing wind power generation equipment. In 2009, the average installed cost for a wind power project in India was INR 53.3 million (USD 1.1 million) per MW, and the installation costs per megawatt will likely continue to decrease. By comparison, the average installation cost in the United States in 2009 was approximately INR 105.0 million (USD 2.1 million) per MW. ${ }^{127}$

India's wind turbine manufacturers currently produce 3,000-3,500 MW of new turbines a year. Five key players (Suzlon, Enercon, RBB Energy, NEPC, and Vestas) cover $80 \%$ of this, and they are also responsible for $90 \%$ of India's new capacity installations in 2009-2010. ${ }^{128}$ By 2015, India's total wind turbine production is expected to rise to 5,000 MW per annum. Several new manufacturers, many of which are local, are now entering the market, and prices for turbines are expected to come down due to increasing competition. According to MNRE, India's export of wind turbines and blades to the United States, Europe, South America, and

\footnotetext{
${ }^{123}$ IREDA. “Central Incentives.” http://www.ireda.in/incentives.asp. Accessed August 2010.

${ }^{124}$ MNRE. http://mnre.gov.in/gbi-scheme.htm. Accessed August 2010.

${ }^{125}$ REEEP. "Policy and Regulatory Review-Special Report on India and Indian States," 2010.

126 IREDA. "Statewise List of Projects with WTGs Commissioned after 17.12.2009 Registered with IREDA for Unique Identification Numbers (UINs) under Generation Based Incentive (GBI) not Availing AD Under Section 44AB of Income Tax Act." http://www.ireda.gov.in/pdf/GBI\%20Projects.pdf. Accessed October 18, 2010.

${ }^{127}$ Wiser, R.; Bolinger, M. “2009 Wind Technologies Market Report.” LBNL-3716E. August 2010. http://eetd.lbl.gov/ea/emp/reports/lbnl-3716e.pdf. Accessed October 2010.

${ }^{128}$ Consolidated Energy Consultants. "Manufacturers-Wise Wind Electric Generators Installed in India," Wind Power India. http://www.windpowerindia.com/statmanuf.html. Accessed August 2010.
} 
Asia is valued at INR 45 billion (USD 900 million) and imports reached INR 22 billion (USD 440 million). ${ }^{129}$

\subsection{Technology Developments}

The current wind technology developed in India has lagged behind technologies produced around the globe. According to MNRE, turbines in India range in capacity from $250 \mathrm{~kW}$ to $2,100 \mathrm{~kW}$ compared to a global maximum of 5,000 kW; hub heights range from $41 \mathrm{~m}$ to $88 \mathrm{~m}$ compared to a global maximum of $117 \mathrm{~m}$; and rotor diameters range from $28 \mathrm{~m}$ to $80 \mathrm{~m}$, compared to a global maximum of $126 \mathrm{~m} .{ }^{130}$

The average capacity of installed wind turbines in India was only $400 \mathrm{~kW}$ in 2000; by 2008 it had reached $1 \mathrm{MW}$. As plant sizes increase, installation costs decrease. GWEC expects that India's average turbine size will reach $1.5 \mathrm{MW}$ by $2013 .{ }^{131}$

Larger turbines require less land for an equal installed capacity, reduced operation and maintenance, and faster commissioning, and very large turbines are starting to enter the market. For example, Suzlon is now assembling turbines of $5 \mathrm{MW}$ and $6 \mathrm{MW}$ through its German subsidiary, REpower. ${ }^{132}$

Upcoming technological developments include wind forecasting to enable integrated grid management and more efficient generation. ${ }^{133}$ There is also a rising interest in offshore wind developments for India, although there has not yet been any significant progress. ${ }^{134}$

\subsection{Local Case Studies}

A major success story in the Indian renewable energy sector has been Suzlon, a company set up in 1995 by Tulsi Tanti. By 2009, Suzlon was the third largest wind turbine manufacturer in the world with a market share of $9.8 \%{ }^{135}$ Suzlon is the leading wind power company in India with a domestic market share of more than $44 \%$ of installed capacity and $26 \%$ of wind turbines sold. ${ }^{136}$ Its success has been attributed to fast delivery and turnaround times that undercut the competition. ${ }^{137}$ In 2006, Suzlon bought the Belgian gearbox maker Hansen, and in 2007, it bought REpower, a German company with offshore wind experience. The company has suffered some recent setbacks, including damage to some of its blades under different environmental conditions. Aggressive leverage for investments, costly blade repair programs, and a global recession have caused the company some recent financial trouble. ${ }^{138}$

\footnotetext{
${ }^{129}$ MNRE. Presentation to Power-Gen India. 3 March 2010, p. 12.

${ }^{130}$ MNRE. Presentation to Power-Gen India. 3 March 2010, p. 10.

${ }^{131}$ GWEC. Indian Wind Energy Outlook 2009.

http://www.indianwindpower.com/pdf/GWEO_A4_2008_India_LowRes.pdf. Accessed August 2010.

${ }^{132}$ Suzlon. "RE Power-built 'Alpha Ventus' Starts Operations; Germany's First Offshore Wind Farm." Press

Release. 28 April 2010. http://www.suzlon.com/media center/press release.aspx?11=7\&12=31. Accessed

September 2010.

${ }^{133}$ MNRE. "Unleashing the Wind Tiger." Renewable Energy World; May 2010.

${ }^{134}$ India Energy Portal. http://www.indiaenergyportal.org/subthemes link.php?text=wind\&themeid=3. Accessed August 2010.

${ }^{135}$ Suzlon. "Key Financial Data." http://www.suzlon.com/investors/13.aspx?11=6\&12=23\&13=43. Accessed August 2010.

${ }^{136}$ Consolidated Energy Consultants. "Manufacturers-Wise Wind Electric Generators Installed in India." Wind

Power India. http://www.windpowerindia.com/statmanuf.html. Accessed August 2010.

137 “Saving Suzlon,” Forbes India. 5 June 2009. http://business.in.com/article/cross-border/saving-suzlon/302/0. Accessed August 2010.

${ }^{138}$ Suzlon. "Unaudited Consolidated Financial Results for the Quarter Ended December 31, 2009." http://www.suzlon.com/images/investor quaterly result/38 Results.pdf. Accessed October 2010.
} 
In June 2010, Suzlon reported a loss of INR 1.8 billion (USD 36 million), citing an order backlog. ${ }^{139}$

Bharat Heavy Electricals Ltd (BHEL), one of India's largest power equipment manufacturers, is entering the wind turbine market in 2010 to help meet the demand for larger turbines in India. The company plans to develop their own blade manufacturing facilities in India, but they plan to have towers manufactured in India and blades sourced from foreign manufacturers in the near term as they look to support deployment of 1.5-2.0 MW turbines. BHEL was an early manufacturer of $250 \mathrm{~kW}$ wind turbines but ceased production in response to a drop in demand. ${ }^{140}$

On the project development side, TATA Power is planning to expand its wind capacity from $200 \mathrm{MW}$ to $500 \mathrm{MW}$ by 2013 and to $2,000 \mathrm{MW}$ by $2017 .{ }^{141}$ Airvoice has announced plans to set up 3,000 MW of wind in Karnataka with $200 \mathrm{MW}$ to be installed in the first phase. ${ }^{142}$

NHPC Limited, a government enterprise and the largest hydropower operator of the country, is currently building a $100 \mathrm{MW}$ wind plant in Madhya Pradesh. ${ }^{143}$ Another government enterprise, Neyveli Lignite Corporation Ltd, announced a $50 \mathrm{MW}$ project in the south-Indian harbor city of Tuticorin ${ }^{144}$ to supply power to a lignite (brown coal) open-pit mining network currently under construction. Oil and Natural Gas Corporation Ltd also has plans to invest INR 65 million (USD 123 million) in a 50 MW project in Gujarat as well as in smaller wind power plants in Karnataka. ${ }^{145}$ The company has plans to install up to 2,000 MW of wind capacity, mainly in the state of Gujarat. ${ }^{146}$

\subsection{Success Stories from the International Community and Potential Opportunities for India}

India's wind industry continues to offer attractive opportunities for investors. In addition to capacity growth through new project development, many outdated and smaller plants will be re-powered, where outdated lower capacity turbines are replaced by modern and larger equipment. ${ }^{147}$

Foreign companies are also becoming involved in the manufacturing sector. For example, Siemens has announced plans to invest INR 5 billion (USD 100 million) to open a $200 \mathrm{MW}$

\footnotetext{
${ }^{139}$ Suzlon. Press Release, 29 May 2010. http://www.suzlon.com/media_center/press_release.aspx?11=7\&12=31. Accessed August 2010.

${ }^{140}$ Narasimhan, T.E. "BHEL Plans to Re-enter Wind Turbine Manufacturing Business." Business Standard, April 2010. http://www.business-standard.com/india/news/bhel-plans-to-re-enter-wind-turbine-manufacturingbusiness/390978/. Accessed August 2010.

${ }^{141}$ TATA Power. “Analyst Meet.” Presented at the TATA Power Company Ltd Analyst Meet, March 2010. http://www.tatapower.com/investor-relations/pdf/analyst-presentation-mar-10.pdf. Accessed August 2010.

142 "Green Energy: Airvoice Lines Up 13,000 MW.” Hindustan Times. New Delhi, 5 February 2010. http://www.hindustantimes.com/News-Feed/markets/Green-energy-Airvoice-lines-up-13-000-mw/Article1505712.aspx. Accessed October 2010.

${ }^{143}$ NHPC Limited. "Press Release." http://www.nhpcindia.com/english/scripts/PressRelease.aspx. Accessed August 2010.

${ }^{144}$ Neyveli Lignite Corporation Limited. "Press Release."

http://www.nlcindia.com/investor/press_release_eng_270510.pdf. Accessed August 2010.

${ }^{145}$ Oil and Natural Gas Ltd. "ONGC's First Wind-farm, Having World's Highest Turbine Capacity, Inaugurated.” http://www.ongcindia.com/press_release1_new.asp?fold=press\&file=press348.txt. Accessed August 2010.

${ }^{146}$ Prashant, S. “ONGC Eyes 2,000 MW Wind Energy.” Rediff India Abroad. 5 Februrary 2008. http://www.rediff.com/money/2008/feb/05wind.htm. Accessed October 18, 2010.

${ }^{147}$ GWEC. "Indian Wind Energy Outlook 2009."

http://www.indianwindpower.com/pdf/GWEO_A4_2008 India_LowRes.pdf. Accessed August 2010.
} 
wind turbine production plant in India with plans to scale up to $500 \mathrm{MW}$ over 3 years. The Spanish manufacturer Gamesa has already commenced operations at its $200 \mathrm{MW}$ manufacturing facility for $850 \mathrm{~kW}$ turbines in Tamil Nadu. ${ }^{148}$

With 7,600 km of coast, the installation of offshore wind plants can play an important role in the growth of India's wind market. Although there is currently little information available regarding the potential for offshore wind in India, C-WET released data in 2008 showing modest prospects along the western coastline with several sites prone to cyclonic conditions. Data collected at the southern coastline, at a monitoring site in Rameshwaram, indicates some potential. However, much of the data has been extrapolated and further in-depth assessment is required. ${ }^{149}$ So far, there has also been little progress by the private sector into exploring this potential. ${ }^{150}$ Companies such as Areva, Siemens, General Electric, and Suzlon are now exploring opportunities in offshore wind in India as the conditions for low-cost generation are improving.

\footnotetext{
${ }^{148}$ Gamesa. "Gamesa Reinforces its Presence in Asia by Starting Up its First Production Center in India." http://www.gamesacorp.com/en/press/press-releases/gamesa-reinforces-its-presence-in-asia-by-starting-up-itsfirst-production-center-in-india. Accessed August 2010.

${ }^{149}$ C-WET. Pavan; Iss. 16, January-March 2008; p. 7, www.cwet.tn.nic.in/Docu/news\%20letter/english/Issue\%2016.pdf. Accessed August 2010.

${ }^{150}$ Energy Alternatives India. "India Offshore Wind-Status, Trends, Potential." http://eai.in/blog/2010/04/india-offshore-wind-status-trends-potential.html. Accessed October 2010.

151 "Areva, Siemens, and GE Explore Offshore Wind-ow in India." Economic Times. http://economictimes.indiatimes.com/news/news-by-industry/energy/power/Areva-Siemens-GE-exploreoffshore-wind-ow-in-India/articleshow/5851229.cms. Accessed August 2010.
} 


\section{Solar Power}

\section{Chapter Overview ${ }^{152}$}

Solar is an important, although currently underutilized, energy resource in India with the potential to offer an improved power supply (especially in remote areas) and increase the security of India's energy supply. On average, the country has 300 sunny days per year and receives an average hourly radiation of $200 \mathrm{MW} / \mathrm{km}^{2}$. The India Energy Portal estimates that around $12.5 \%$ of India's land mass, or $413,000 \mathrm{~km}^{2}$, could be used for harnessing solar energy. ${ }^{153}$ This area could be further increased by the use of building-integrated PV. Though large-scale CSP has not yet been deployed in India, one study has estimated that this technology alone could generate 11,000 TWh per year for India. In addition to India's potential for widespread deployment of solar technologies to supply electricity across the country, India also has the potential to significantly reduce electricity demand through increased deployment of solar water heaters (SWH), which can be deployed on rooftops in the built environment.

Although India already has a strong solar cell production industry, until now, there has not been a high demand for them in the domestic market. In response to the announcement of JNNSM in November 2009, substantial expansion in the domestic solar market is anticipated. JNNSM's target of achieving at least $20,000 \mathrm{MW}^{154}$ of grid-connected solar power by 2022 could make India one of the leading solar countries in the world, not only in total installed solar capacity but also in manufacturing components and technology research and development. The target encourages development of both PV and CSP technologies by allocating 10,000 MW of the goal to each technology.

According to JNNSM, a further 2,000 MW of off-grid solar power capacity are to be installed by 2022. In order to achieve the goals, MNRE seeks to create an attractive environment for investors, including incentives such as feed-in tariffs. ${ }^{155,156}$ Policies enacted for the first phase will be reviewed in the summer of 2011 to incorporate first lessons learned.

\subsection{Solar Photovoltaics}

India's installed solar power capacity of $15.2 \mathrm{MW}$ at the end of June 2010 was based entirely on $\mathrm{PV}$ technology with approximately $20 \%$ of the capacity being used for off-grid applications. ${ }^{157}$ Currently, more attention is being paid to large-scale solar PV projects. In Phase 1 of JNNSM, which ends in 2013, India aims to install $500 \mathrm{MW}$ of grid-connected solar PV power. ${ }^{158}$ New PV projects are also being registered under state programs such as in Punjab, Gujarat, West Bengal, Rajasthan, and Karnataka, though many of these are being migrated to JNNSM. The creation of special economic zones that provide land, water, and power as well as financial incentives has spurred growth in the domestic manufacturing

\footnotetext{
${ }^{152}$ Chapter 4 discusses solar PV, CSP, and SWH. Solar process heat for industry and solar cooling are discussed briefly in Chapters 7 and 10, respectively.

${ }_{153}$ India Energy Portal. http://www.indiaenergyportal.org. Accessed August 2010.

${ }^{154}$ The megawatts used throughout this chapter to represent solar power capacity are peak megawatts, meaning the maximum rated power based on the equipment's power ratings under standard conditions.

${ }^{155}$ MNRE. "Jawaharlal Nehru National Solar Mission: Towards Building SOLAR INDIA." http://mnre.gov.in/pdf/mission-document-JNNSM.pdf. Accessed August 2010.

${ }^{156}$ MNRE. "Guidelines for New Grid Connected Solar Power Projects." July 2010. http://www.mnre.gov.in/pdf/jnnsm-gridconnected-25072010.pdf. Accessed October 2010. ${ }_{157}$ MNRE. “Achievements." http://www.mnre.gov.in/achievements.htm. Accessed September 2010.

${ }^{158}$ MNRE. "Jawaharlal Nehru National Solar Mission: Towards Building SOLAR INDIA." http://mnre.gov.in/pdf/mission-document-JNNSM.pdf. Accessed August 2010.
} 
sector. International companies from all over the world are now lining up to get a share of India's solar market, which is valued at INR 3,500 billion (USD 70 billion) through the end of JNNSM in 2022.

\subsubsection{Resource/Technological Potential}

Estimates of global horizontal irradiance (GHI) for India are available from several different organizations. The U.S. National Aeronautics and Space Administration (NASA) Surface Meteorology and Solar Energy (SSE) dataset provides estimates of GHI at a $1^{\circ}$ spatial resolution, which is approximately $100 \mathrm{~km}$ at $26^{\circ} \mathrm{N}$ latitude and can be visualized and downloaded from the Solar and Wind Energy Resource Assessment (SWERA) Web site. ${ }^{159}$ Solar resource maps at

40-km spatial resolution developed using the National Renewable Energy Laboratory (NREL) Climatological Solar Radiation model are also available from SWERA.

NREL has recently released 10-km resolution solar resource maps for India based on the SUNY satellite to irradiance model. ${ }^{160}$ Figure 4-1 shows the annual average GHI across India, which illustrates that most areas of the country have greater than $5.5 \mathrm{kWh} / \mathrm{m}^{2} /$ day of GHI, and the amount reaching a collector could be augmented by optimizing its orientation.

\footnotetext{
${ }^{159}$ SWERA Renewable Energy Resource EXplorer. http://na.unep.net/swera ims/map2/. Accessed August 2010.

${ }^{160}$ NREL. http://www.nrel.gov/international/ra india.html. Accessed September 2010.
} 


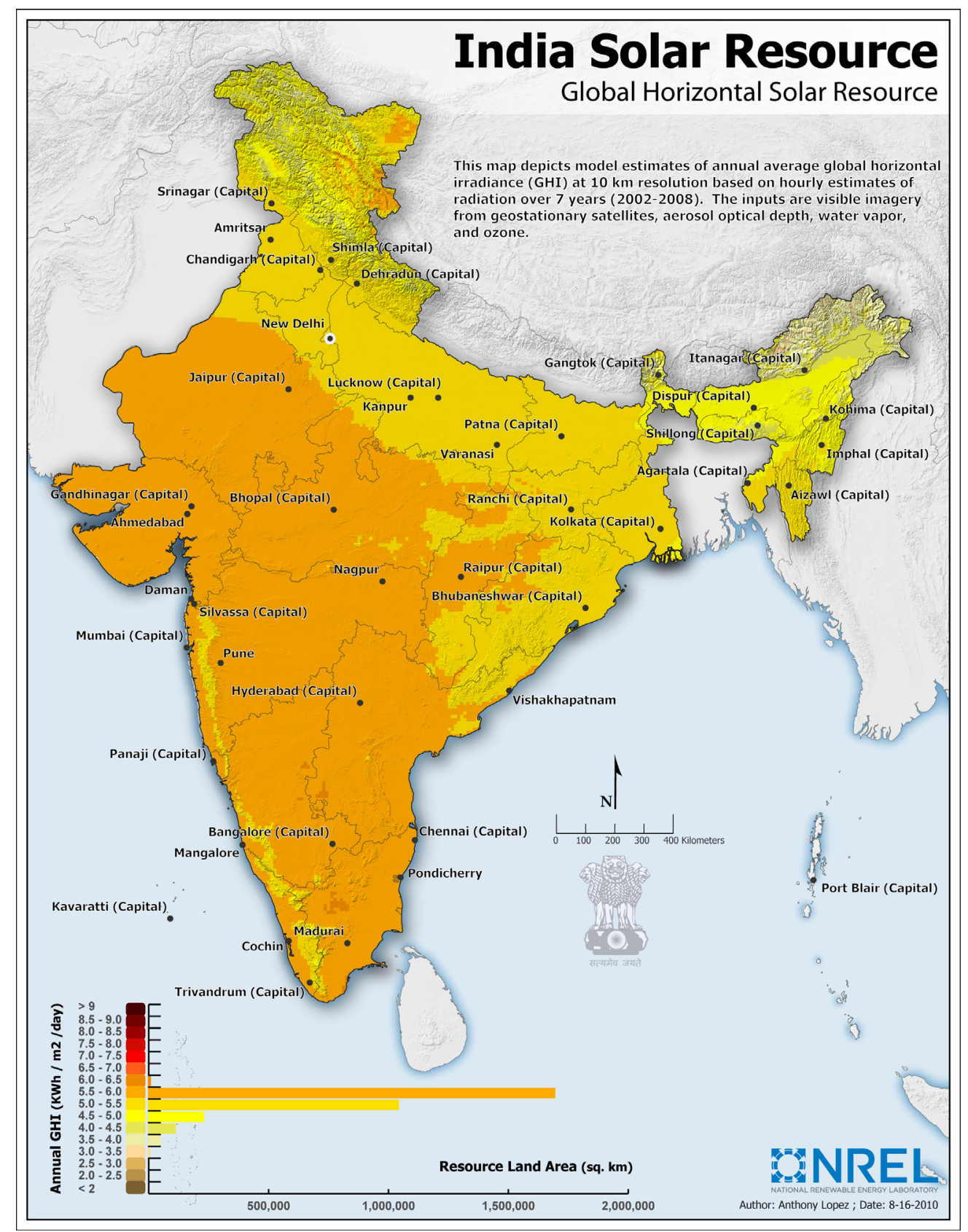

Figure 4-1. India's $\mathrm{GHI}$ resource at $10 \mathrm{~km}$ resolution

\subsubsection{Existing Grid-connected and Off-grid Installed Solar Photovoltaics Capacity}

As of June 2010, India's grid-tied PV solar power was only $12.28 \mathrm{MW}$, or $0.07 \%$, of the total 17,174 MW of grid-connected renewable power capacity. ${ }^{161}$ During 2009-2010, Solar PV projects accounted for $0.5 \%$ of grid-connected renewable energy additions. ${ }^{162}$

Off-grid and decentralized solar applications have been relatively more successful due to direct subsidies and government-financed pilot projects. The total decentralized installed solar capacity as of June 2010 was $2.92 \mathrm{MW}$, or $0.7 \%$, of the total $420 \mathrm{MW}$ of off-grid

\footnotetext{
${ }^{161}$ MNRE. http://mnre.gov.in/achievements.htm. Accessed September 2010.

${ }^{162}$ MNRE. 2009 Annual Report. Table 1.1. http://mnre.gov.in/annualreport/2009-10EN/index.htm. Accessed September 2010.
} 
renewable power. ${ }^{163}$ These decentralized applications include solar street and home lighting systems, solar lanterns, solar cookers, and water pumps.

\subsubsection{Policies, Measures, and Local Regulations}

Over the last decade, a number of programs administered by the central government and some state governments have tried to initiate solar power projects, albeit without much success.

The Tenth Plan (2002-2007) targeted the installation of 5 MW of solar PV; however, only $1 \mathrm{MW}$ was installed during that period. ${ }^{164}$ The Eleventh Plan (2008-2012) originally established a combined target of $50 \mathrm{MW}^{165}$ for both solar PV and CSP, and, in spite of an INR 15 (USD 0.30) feed-in tariff over 12 years offered by MNRE, no new projects were built due to the relatively high cost. India's current federal and state policies designed to encourage deployment of grid-tied solar PV are discussed in Sections 4.1.3.1 and 4.1.3.2, some of which also promote off-grid PV. Policies focused exclusively on off-grid renewable systems are covered in the decentralized energy chapter (Chapter 7).

\subsubsection{JNNSM}

Officially launched in November 2009, JNNSM is one of the eight National Missions laid out in India's NAPCC. It aims to incentivize the installation of 22,000 MW of on- and off-grid solar power using both PV and CSP technologies by 2022 as well as a large number of other solar applications such as solar lighting, heating, and water pumps. As the power trading arm of the National Thermal Power Corporation (NTPC), NTPC Vidyut Vyapar Nigam Ltd (NVVN) has been designated as the nodal agency to ensure the execution of Phase 1 of the mission. ${ }^{166}$

JNNSM aims to address the shortcomings of prior schemes through revised and more attractive feed-in tariffs, a single-window application process, and RPOs that include a solar purchase obligation. ${ }^{167}$ In February 2010, CERC announced a feed-in tariff for financial year 2010-2011 of INR 17.9 (USD 0.36) per kWh for PV and INR 15.3 (USD 0.31) per kWh for CSP and declared that Power Purchase Agreements (PPAs) would have a validity of 25 years. It is assumed that at current cost levels, the tariff will allow investors to achieve an internal rate of return of about 16\%-17\% after taxes. CERC will revise the tariff every year. Ideally, by 2022, installation costs will come down significantly to enable solar power to achieve grid parity so that it becomes a viable source for India's energy needs in the absence of government incentives. Assuming a continuing decrease in PV costs over the span of JNNSM, even as the preferential feed-in tariff is reduced in subsequent years, the share of solar power in the energy mix should continue to increase. ${ }^{168}$ Under JNNSM, the NVVN is

\footnotetext{
${ }^{163}$ MNRE. http://mnre.gov.in/achievements.htm. Accessed September 2010

${ }^{164}$ Government of India Planning Commission. "Eleventh Five Year Plan 2007-12: Volume III Agriculture, Rural Development, Industry, Services, and Physical Infrastructure.” p. 414, http://planningcommission.nic.in/plans/planrel/fiveyr/11th/11_v3/11th_vol3.pdf. Accessed August 2010. ${ }^{165}$ Government of India Planning Commission. "Eleventh Five Year Plan 2007-12: Volume III Agriculture, Rural Development, Industry, Services, and Physical Infrastructure.” p. 414, http://planningcommission.nic.in/plans/planrel/fiveyr/11th/11_v3/11th_vol3.pdf. Accessed August 2010.

${ }^{166}$ MNRE. "Jawaharlal Nehru National Solar Mission: Towards Building SOLAR INDIA." http://mnre.gov.in/pdf/mission-document-JNNSM.pdf. Accessed August 2010.

${ }^{167}$ Mishra, R. "Solar Power: Govt Hopes to Seal Buy-Deals for $800 \mathrm{MW}$ this Fiscal." Hindu Business Line; May 2010. http://www.thehindubusinessline.com/2010/05/11/stories/2010051153030400.htm. Accessed August 2010.

${ }^{168}$ CERC, New Delhi. Tariff Order. Petition No.53/2010. http://cercind.gov.in/2010/ORDER/February2010/532010 Suo-Motu RE Tariff Order FY2010-11.pdf. Accessed August 2010.
} 
required to purchase the expensive solar power from developers and bundle it with an equivalent amount of its much cheaper coal-based power before selling the mixed power to the various utilities at a marketable price. ${ }^{169}$

Three phases are identified under JNNSM. Grid-connected solar projects that signed PPAs prior to November 19, 2009, were eligible to migrate to JNNSM under certain conditions until February 29, 2010. ${ }^{170}$ At the end of each phase there will be a thorough reevaluation of the process. ${ }^{171}$

\section{Phase 1: 2010-2013}

The focus during Phase 1 is to experiment with incentive structures and to create a market for solar power in India by bringing in investors, engineer-procure-construct (EPC) contractors, and equipment manufacturers. Both on- and off-grid projects will be promoted during this phase with the expectation that $500 \mathrm{MW}$ of grid-connected and $200 \mathrm{MW}$ of off-grid solar PV will be installed. ${ }^{172}$

The allocation of $500 \mathrm{MW}$ of grid-connected PV projects will be decided in two batches. The first will be in financial year 2010-2011 and the second in financial year 2011-2012. The first batch will allocate $150 \mathrm{MW}$. Under migration guidelines, projects migrating from older incentive schemes to newer ones should be selected prior to new projects. If applications exceed $150 \mathrm{MW}$, projects will be chosen based on the discount offered by project developers on the CERC tariff. Under the second batch, additional projects will be selected up to 350 MW of remaining capacity. Projects will feed into the grid at $33 \mathrm{kV}$ or above. Individual projects will have a capacity maximum of $5 \mathrm{MW}( \pm 5 \%)$, and each company can only apply for one PV project under Phase 1 (but can also apply for one CSP project). ${ }^{173}$

Applying for a project under Phase 1 of JNNSM requires a company to have an audited net worth of at least INR 30 million (USD 600,000) per MW of a project's installed capacity or INR 150 million (USD 3 million) for a $5 \mathrm{MW}$ project in at least one of the last four financial years. A company must provide a "Bid Bond," or third-party guarantee, per megawatt for any discount on the offered tariff. The higher the discount, the higher the amount of the bond, ranging between INR 10,000 (USD 200) and INR 50,000 (USD 1,000) per MW on a graded scale. Furthermore, the company must provide an earnest money deposit (EMD) in the form of a bank guarantee of INR 2 million (USD 40,000) per MW along with the initial request for selection and, later, a performance bank guarantee of INR 3 million (USD 60,000) per MW at the time of signing the PPA. A project shall achieve financial closure within 180 days before the signing and must be commissioned within 12 months after the signing of the PPA. ${ }^{174}$ To ensure PV module quality, modules proposed for the project must qualify to the latest edition of the following International Electrotechnical Commission (IEC) PV module qualification

\footnotetext{
${ }^{169}$ MNRE. National Solar Mission, Guidelines for New Grid Connected Solar Power Projects, July 2010. http://www.mnre.gov.in/pdf/jnnsm-gridconnected-25072010.pdf. Accessed October 2010.

${ }^{170}$ MNRE. "Guidelines for Migration of Existing Under Development Grid Connected Solar Projects from Existing Arrangements to the Jawaharlal Nehru National Solar Mission (JNNSM).” http://www.mnre.gov.in/pdf/migration-guidelines-jnnsm.pdf. Accessed August 2010. ${ }^{171}$ MNRE. "Jawaharlal Nehru National Solar Mission: Towards Building SOLAR INDIA." http://mnre.gov.in/pdf/mission-document-JNNSM.pdf. Accessed August 2010.

${ }_{172}$ MNRE. National Solar Mission, Guidelines for New Grid Connected Solar Power Projects, July 2010. http://www.mnre.gov.in/pdf/jnnsm-gridconnected-25072010.pdf. Accessed October 2010.

${ }^{173}$ MNRE. National Solar Mission, Guidelines for New Grid Connected Solar Power Projects, July 2010. http://www.mnre.gov.in/pdf/jnnsm-gridconnected-25072010.pdf. Accessed October 2010.

${ }^{174}$ The net worth calculations: paid-up share capital plus reserves minus revaluation reserves minus intangible assets minus miscellaneous expenditures to the extent not written off or carry forward losses.
} 
test or equivalent from the Bureau of Indian Standards: for crystalline silicon solar cell modules-IEC 61215; for thin-film modules-IEC 61646; and for concentrator PV modules-IEC 62108. For the first batch of Phase 1, it will be mandatory for projects using crystalline silicon technology to use modules manufactured in India. ${ }^{175}$

\section{Phase 2: 2013-2017}

During Phase 2, the goal is to build on the experience of Phase 1 to facilitate a substantial increase in capacity additions, significantly bring down the cost per kilowatt-hour, and achieve additional installations of 3,000-10,000 MW of combined PV and CSP capacity. JNNSM identifies the need for international support in the form of technology transfer and financial assistance in order to meet the higher goal. The central government will work to create a favorable environment for solar manufacturing, particularly for solar thermal technology manufacturing. By 2017, the goal is for the installation of 15 million $\mathrm{m}^{2}$ of solar thermal collector area and for off-grid solar capacity to reach 1,000 MW. For Phase 2, it will be mandatory to use cells and modules manufactured in India. ${ }^{176}$

\section{Phase 3: 2017-2022}

Solar power is expected to achieve grid parity by 2022 through the final goals of the JNNSM: off-grid solar capacity installations will reach $2,000 \mathrm{MW}$, on-grid capacity will reach 20,000 MW, 20 million $\mathrm{m}^{2}$ of solar thermal collector area will be installed, and 20 million solar lighting systems will be deployed in rural households.

\subsubsection{State Policies}

Independent of these national efforts, states are promoting solar power. Gujarat, for example, is promoting the installation of $350 \mathrm{MW}$ solar PV by 2011. It offers a feed-in tariff of INR 15 (USD 0.30) per $\mathrm{kWh}$ for the first 12 years and INR 5 (USD 0.10) per $\mathrm{kWh}$ for the following 13 years. In addition, there is an accelerated depreciation option of $80 \%$ in the first year of operation. The program has some uncertainties, however. First, it is unclear if the accelerated depreciation falls under jurisdiction of the state or the central government. Second, Gujarat Urja Vikas Nigam Limited, the organization responsible for the bulk purchase and sale of electricity, will buy the power from the solar projects only based on its power demand. The policy process is still evolving. ${ }^{177}$

Allocations for the Gujarat $350 \mathrm{MW}$ PV program have been made to a number of interested promoters, but actual project execution has so far lagged behind. Narenda Modi, Chief Minister of Gujarat, is driving the policy by making use of the state's land availability and excellent irradiation and is making Gujarat the Indian hub of solar technology. In addition to the state of Gujarat, other states such as Rajasthan, Maharashtra, Andhra Pradesh, and Karnataka are developing their own solar policies. ${ }^{178}$

\subsubsection{Investment Flows and Industrial Trends}

As of May 2010, there were four major PV plants connected to the grid in India. The first was a 1 MW plant by West Bengal Renewable Energy Development Corporation. The second was a 1 MW plant by private developer Azure Power in Punjab. The most recent additions are a

\footnotetext{
${ }^{175}$ MNRE. National Solar Mission, Guidelines for New Grid Connected Solar Power Projects, July 2010. http://www.mnre.gov.in/pdf/jnnsm-gridconnected-25072010.pdf. Accessed October 2010.

${ }^{176}$ MNRE. National Solar Mission, Guidelines for New Grid Connected Solar Power Projects, July 2010. http://www.mnre.gov.in/pdf/jnnsm-gridconnected-25072010.pdf. Accessed October 2010.

${ }^{177}$ Kumar, S. "Indian Solar Market Update.” Solar Snippet. Credit Suisse. 23 June 2010.

${ }^{178}$ Kumar, S. "Indian Solar Market Update.” Solar Snippet. Credit Suisse. 23 June 2010.
} 
3 MW plant by Karnataka Power Trading Corporation and a 1 MW plant by Maharashtra Generation Corporation. ${ }^{179}$

Several new PV power plants are in the pipeline, including 365 MW in Gujarat and $36 \mathrm{MW}$ in Rajasthan. ${ }^{180}$ Titan Energy, a leading Indian module manufacturer and EPC contractor, and Enfinity, a global project developer, announced plans to install 1,000 MW of solar PV on 3,000 acres in Andhra Pradesh. ${ }^{181}$

In the past couple of years, the number of PV module and cell suppliers in India has tripled to $30{ }^{182}$ As of 2009 , total module production rose from less than $60 \mathrm{MW}$ to over $1,000 \mathrm{MW}$ per annum. Thus far, it has catered primarily to the export market. ${ }^{183}$ Production is projected to grow at a rate of $20 \%-25 \%$, reaching $2,575 \mathrm{MW}$ by $2015 .{ }^{184} \mathrm{JNNSM}$ targets $4,000-5,000$ MW in annual domestic module manufacturing capability by $2022 .{ }^{185}$

PLG Ltd., one of India's largest module manufacturing companies, is in the process of upgrading its $50 \mathrm{MW}$ facility to $100 \mathrm{MW} .{ }^{186}$ Tata BP Solar recently signed an agreement with Calyon Bank and BNP Paribas to raise INR 3,900 million (USD 78 million) to fund further development. ${ }^{187}$ It currently has a cell manufacturing capacity of $84 \mathrm{MW}$ and a module manufacturing capacity of $125 \mathrm{MW}$ with plans to expand to $300 \mathrm{MW} .^{188}$

The creation of special economic zones, providing land, water, and power as well as financial incentives, has further spurred growth in the domestic manufacturing sector. A Special Incentive Package Scheme (SIPS), introduced in 2007, provides subsidies of $20 \%-25 \%$ for semi-conductor and eco-system (solar cells and PV) manufacturing units. These financial incentives enable vertically integrated manufacturing facilities to achieve economies of scale. As of the scheme deadline of March 31, 2010, there had been 26 applications for solar PV facilities with a cumulative investment of INR 2,290 billion (USD 45.8 billion). ${ }^{189}$

A number of companies that have submitted proposals for new production capacities under SIPS have been approved in principal. Approved companies include Titan Energy Systems, Reliance Energies, TATA BP Solar, PV Technologies India, KSK Surya PV Ventures, Signet

\footnotetext{
${ }^{179}$ Dutta, A.P. "New Gold Rush.” Down to Earth Magazine; 1-5 June 2010.

${ }^{180}$ Kumar, S. "Indian Solar Market Update." Solar Snippet. Credit Suisse. 23 June 2010.

${ }^{181}$ Titan Energy. "Titan Energy Systems and Enfinity To Develop, Finance And Construct 1 GWp of PV Installations In Andhra Pradesh, India." 9 November 2009, http://www.titansolar.com/titan/press 9nov2009.html. Accessed August 2010.

${ }^{182}$ Frost and Sullivan. "India Solar Photovoltaic Market Shines Bright as the Government Encourages Private Investments, finds Frost \& Sullivan.” 9 February 2010, http://www.frost.com/prod/servlet/pressrelease.pag?docid=192215618. Accessed October 2010.

${ }^{183}$ Frost and Sullivan. "India Solar Photovoltaic Market Shines Bright as the Government Encourages Private Investments, finds Frost \& Sullivan.” 9 February 2010, http://www.frost.com/prod/servlet/pressrelease.pag?docid=192215618. Accessed August 2010. Accessed October 2010.

${ }^{184}$ Frost and Sullivan. "Future of the Indian Solar PV Industry." 25 January 2010. http://www.frost.com/prod/servlet/market-insight-top.pag?docid=190682409. Accessed August 2010.

${ }^{185}$ MNRE. "Guidelines for Migration of Existing Under Development Grid Connected

Solar Projects from Existing Arrangements to the Jawaharlal Nehru National

Solar Mission (JNNSM).” http://www.mnre.gov.in/pdf/migration-guidelines-jnnsm.pdf. Accessed August 2010.

${ }^{186}$ PLG Ltd. http://www.plgpower.com/about-milestones.asp. Accessed August 2010.

${ }^{187}$ TATA BP Solar. "Tata BP Solar Raises \$78 Million for Further Investments in Solar Energy."

17 March 2008. http://www.tatabpsolar.com/future invest.html. Accessed August 2010.

188 TATA BP Solar. "Tata BP Solar Expands Solar Manufacturing Capacity by $62 \%$ to Serve Growing Solar Market in India." 28 April 2010. http://www.tatabpsolar.com/solar-expands.html. Accessed October 2010.

${ }^{189}$ Hindu Business Line. "Solar Power Scheme Draws Rs. 2.2-lakh cr Proposals." 14 April 2010. http://www.thehindubusinessline.com/2010/04/15/stories/2010041556760100.htm. Accessed August 2010.
} 
Solar, Indo-Solar, Solar Semiconductors, TF Solar Power, Lanco Solar, EPV Solar, and Bhaskar Solar. ${ }^{190}$ Companies undertaking projects without a SIPS incentive include Bharat Electronics and BHEL, who together are planning a joint $250 \mathrm{MW}$ PV production facility, and ONGC, who is planning a $60 \mathrm{MW}$ production facility. ${ }^{191}$

\subsubsection{Technology Development and Transfer}

While production of PV modules is on the rise in India, module manufacturers are highly dependent on imports of the silicon wafers used in module manufacturing. ${ }^{192}$ For this reason, the government wants to promote the production of silicon material in India. The Eleventh Plan proposed funding of INR 1.2 billion (USD 24 million) from the National Energy Fund to promote the manufacturing of polysilicon. ${ }^{193} \mathrm{MNRE}$ and MoP plan to make it mandatory for developers to supply crystalline silicon-based modules from domestic manufacturers. However, the import of solar cells to manufacture modules is still permitted. ${ }^{194}$

Thin-film modules are also manufactured in India. These are less expensive than crystalline modules but also less efficient. ${ }^{195}$ Signet Solar, a U.S. company, is planning a $300 \mathrm{MW}$ production facility for thin-film modules in Tamil Nadu. ${ }^{196}$ The Indian company TF Solar Power wants to invest INR 23.5 billion (USD 470 million) in the production of thin-film modules. ${ }^{197}$ Poseidon Solar, an Indian-based silicon recycling company, recently announced their capability to recycle Cadmium-Telluride based thin-film modules, which will significantly reduce component costs for developers. ${ }^{198}$

Multi-junction cells are a promising technology on the horizon; however, there has not yet been much research and development on this in India. ${ }^{199}$

\subsubsection{Local Case Studies}

In 2009, Azure Power set up the first private grid-connected solar PV plant in Punjab with a capacity of $1 \mathrm{MW}$ and servicing 20,000 households. ${ }^{200}$ In line with its ambitious targets of establishing $100 \mathrm{MW}$ solar power capacity, it is now developing a $15 \mathrm{MW}$ plant in Gujarat in collaboration with U.S.-based company SunEdison. According to Azure, the cost of PV installation is already coming down; its first plant cost INR 190 million (USD 3.8 million) per MW; the new plant will cost 10\% less at INR 170 million (USD 3.4 million) per MW. Future costs are expected to drop down by a further $10 \%-12 \%$. Both plants are under the respective state GBI schemes. Both are 30 -year contracts by which power will be sold at INR 15 (USD 0.30) for the first 10 years in Punjab and the first 12 years in Gujarat. For the

\footnotetext{
${ }^{190}$ Hindu Business Line. "Solar Power Scheme Draws Rs. 2.2-lakh cr Proposals.” 14 April 2010. http://www.thehindubusinessline.com/2010/04/15/stories/2010041556760100.htm. Accessed August 2010. ${ }^{191}$ New Energy. "End of the Solar Eclipse." September 2009, Iss. 5; p. 82.

192 MNRE. "Jawaharlal Nehru National Solar Mission: Towards Building SOLAR INDIA." http://mnre.gov.in/pdf/mission-document-JNNSM.pdf. Accessed August 2010.

${ }^{193}$ Government of India Planning Commission. "Eleventh Five Year Plan 2007-12: Volume III Agriculture, Rural Development, Industry, Services, and Physical Infrastructure.” p. 417, http://planningcommission.nic.in/plans/planrel/fiveyr/11th/11_v3/11th_vol3.pdf. Accessed August 2010.

${ }^{194}$ The Hindu Business Line. TERI Newswire, Vol. 16., No. 10, 16-31 May 2010; p. 16.

${ }^{195}$ Dutta A.P. "New Gold Rush.” Down to Earth Magazine 1-5 June 2010.

${ }^{196}$ Signet Solar "Signet Solar Expands Manufacturing Capacity with India Plant." 17 March 2008. http://www.signetsolar.com/pdf/Signet_Solar_Global_Press_Release_mar_17_08.pdf. Accessed August 2010. ${ }_{197}$ TF Solar Power. http://www.tfsolarpower.com/. Accessed August 2010.

198 Poseidon Solar. "Poseidon Solar Announces its Capability to Reclaim CdTe Thinfilm Solar Cells." 3 December 2009. http://poseidonsolar.com/latest-news/8.html. Accessed August 2010.

${ }^{199}$ Dutta A.P. "New Gold Rush." Down to Earth Magazine 1-5 June 2010.

${ }^{200}$ Azure. http://www.azurepower.com. Accessed August 2010.
} 
remaining time periods, the tariff will reduce to INR 8.93 (USD 0.18) in Punjab and INR 5 (USD 0.10) in Gujarat. ${ }^{201}$

RIL Solar Group - part of Reliance Industries — will provide solar power to the Commonwealth Games in Delhi in 2010. ${ }^{202}$ The company built the first $1 \mathrm{MW}$ rooftop PV installation on the Thyagaraj stadium in New Delhi in less than 3 months. The plant is expected to generate 1.4 million $\mathrm{kWh}$ of electricity per year, and the surplus will be delivered to the distribution grid.

Moser Baer PV, launched in 2005, is one of India's leading cell and module manufacturers. The company is a subsidiary of Moser Baer, which was founded in 1983 and has since become the second largest producer of optical storage media. ${ }^{203}$ Moser Baer PV established itself across the value chain, offering end-to-end solutions for on- and off-grid solar PV installations. It has a production capacity of $90 \mathrm{MW}$ crystalline cells, $90 \mathrm{MW}$ crystalline modules, and $50 \mathrm{MW}$ of thin film. The company also has solar PV power plants of $15 \mathrm{MW}$ approved in Gujarat and $5 \mathrm{MW}$ in Rajasthan and successfully commissioned 50 projects in India and Germany in 2009. ${ }^{204}$

\subsubsection{Success Stories from the International Community and Potential Opportunities for India}

Germany has the largest solar PV power generation capacity, despite a significantly lower solar resource compared to India and many other countries. In 2009 alone, with 3,800 MW of added capacity, it accounted for more than half of the global market. Spain was the world leader in 2008 with 2,400 MW additional PV installations. ${ }^{205}$ The high rate of new installations in these two countries is due to highly favorable regulatory environments. Both countries offer attractive long-term feed-in tariffs ( 20 years in Germany and 25 years in Spain) and have provided an overall conducive investor environment. Although the tariffs are reduced every year and are about to be cut by double digits in 2010, the deployment of new solar capacity is still high. One result of this is that German cell production companies are among the most successful in the world. The German company Q-Cells was the world's top cell producer in 2008 with $570 \mathrm{MW}$ produced. $^{206}$

International companies from all over the world are now lining up to get a share in India's solar market, which is valued at INR 175 billion (USD 3.5 billion) through 2013 and INR 3,500 billion (USD 70 billion) through the end of JNNSM in $2022 .{ }^{207}$ Solar PV companies

\footnotetext{
${ }^{201}$ Bondre, K. “Interview-India's Azure Power Plans 100 MW Solar Projects” Reuters 19 May 2010. http://in.reuters.com/article/idINBMB01063720100519. Accessed August 2010.

${ }^{202}$ RIL Solar Group. 7 April 2010, http://www.ril.com/downloads/pdf/PR07042010R.pdf. Accessed August 2010.

${ }^{203}$ Moser Baer. http://www.moserbaerpv.in/about-overview.asp?links=ab1. Accessed August 2010.

${ }^{204}$ Moser Baer. 24 June 2010. http://www.moserbaerpv.in/media-press-details-june20-10.asp?links=me2. Accessed August 2010.

${ }^{205}$ REN 21. "Renewables 2010: Global Status Report."

http://www.ren21.net/globalstatusreport/REN21_GSR 2010 full.pdf. Accessed August 2010.

${ }^{206}$ Joint Research Center. "PV Status Report 2009.” http://re.jrc.ec.europa.eu/refsys/pdf/PV-Report2009.pdf. Accessed August 2010.

${ }^{207}$ Walet, L. “Foreign Companies Take a Shine to India’s \$70 Billion Solar Programme.” Mint 18 June 2010. http://www.livemint.com/2010/06/17215210/Foreign-companies-take-shine-t.html?atype=tp. Accessed August 2010.
} 
that have cost-competitive products, such as China-based Suntech and U.S.-based First Solar, are pegged to have an advantage over others. ${ }^{208}$

Gujarat has proved a popular destination for investment with 24 solar developers getting $365 \mathrm{MW}$ of PV capacity approved as of June $2010 ;{ }^{209}$ the market is attracting both domestic and international investors. German companies Dreisatz $\mathrm{GmbH}$ and $\mathrm{Mi} \mathrm{GmbH}$, each have $25 \mathrm{MW}$ of approved projects in Gujarat. ${ }^{210}$ U.S.-based project developer Astonfield recently announced a partnership with Belectric for a $5 \mathrm{MW}$ plant in Osiyan, Rajasthan, which is to be migrated to JNNSM. ${ }^{211}$ The required land is 30 acres, but Astonfield has secured an additional 185 acres for future expansion of the plant to $20 \mathrm{MW} .^{212}$

\subsection{Concentrating Solar Power}

JNNSM recognizes the potential of CSP as a highly effective energy source and is expecting a significant proportion of CSP in its solar goals even in Phase 1, with $500 \mathrm{MW}$ of grid-tied CSP targeted for 2013 and $10 \mathrm{GW}$ targeted by 2022. CSP is currently still at the research and development (R\&D) stage in India. A feed-in tariff was announced by CERC in February 2010 together with several other instruments to incentivize manufacturers for solar collector production. States such as Gujarat are introducing their own policies to stimulate CSP development, such as exempting the generated electricity from electricity duty.

\subsubsection{Resource/Technological Potential}

In its CSP roadmap, the IEA included northwestern India among its list of world regions showing the best solar resource for CSP projects. ${ }^{213}$ One of the benefits that CSP offers over $\mathrm{PV}$ is the ability to include thermal storage in system designs. This enables a continual supply of power that does not hamper grid stability and allows CSP facilities to operate as base load plants. ${ }^{214}$ CSP has so far been successfully implemented in only a few locations worldwide, such as the U.S. southwestern desert. ${ }^{215}$ India's foray into CSP began in 1994 with a feasibility study for an INR 12.3 billion (USD 245 million), 35 MW CSP plant in Mathania, Rajasthan, to be co-financed by the government and KfW. However, the project was postponed indefinitely because no qualified contractors were able to submit a bid.

There are several maps and data sources available that estimate the availability of direct normal irradiance (DNI) at locations across India. The NASA SSE dataset provides estimates

\footnotetext{
${ }^{208}$ Walet, L. “Foreign Companies Take a Shine to India’s \$70 Billion Solar Programme.” Mint 18 June 2010. http://www.livemint.com/2010/06/17215210/Foreign-companies-take-shine-t.html?atype=tp. Accessed August 2010.

${ }^{209}$ Kumar, S. "Indian Solar Market Update.” Solar Snippet. Credit Suisse. 23 June 2010.

${ }^{210}$ Kumar, S. "Indian Solar Market Update.” Solar Snippet. Credit Suisse. 23 June 2010.

211 Astonfield. “Astonfield and Belectric Team up to Realize 5MW Solar Power Plant in Rajasthan, India." 11 May 2010. http://www.astonfield.com/press/pr/Astonfield-PR-Belectric-May2010-FINAL.pdf. Accessed August 2010.

${ }^{212}$ Astonfield. "Astonfield and Belectric Team up to Realize 5 MW Solar Power Plant in Rajasthan, India." 11 May 2010. http://www.astonfield.com/press/pr/Astonfield-PR-Belectric-May2010-FINAL.pdf. Accessed August 2010.

${ }^{213}$ IEA. "Technology Roadmap: Concentrating Solar Power." http://www.iea.org/papers/2010/csp_roadmap.pdf. Accessed August 2010.

${ }^{214}$ IEA. Solar Paces, http://www.solarpaces.org/News/Projects/India.htm. Accessed August 2010.

${ }^{215}$ DESERTEC Foundation. "Red Paper" p. 7. http://www.desertec.org/fileadmin/downloads/desertecfoundation redpaper 3rd-edition english.pdf. Accessed August 2010.
} 
of DNI at a $1^{\circ}$ spatial resolution, and NREL's Climatological Solar Radiation model provides estimates at $40-\mathrm{km}$ resolution, both of which are available from SWERA. ${ }^{216}$

NREL has recently released 10-km resolution solar resource maps for India based on the SUNY satellite to irradiance model. ${ }^{217}$ Figure 4-2 shows the annual average DNI across India, which illustrates that most areas of the country have greater than $5 \mathrm{kWh} / \mathrm{m}^{2} /$ day of DNI. This image shows the areas of highest resource occurring in the northwest desert regions and the high-elevation Himalayan region. Figure 4-2 also shows large areas with annual average DNI greater than $5.5 \mathrm{kWh} / \mathrm{m}^{2} /$ day in Madhya Pradesh and Maharashtra and smaller land areas with similar resources in several additional states.

${ }^{216}$ SWERA Renewable Energy Resource EXplorer. http://na.unep.net/swera ims/map2/. Accessed August 2010.

${ }^{217}$ NREL. http://www.nrel.gov/international/ra india.html. Accessed September 2010. 


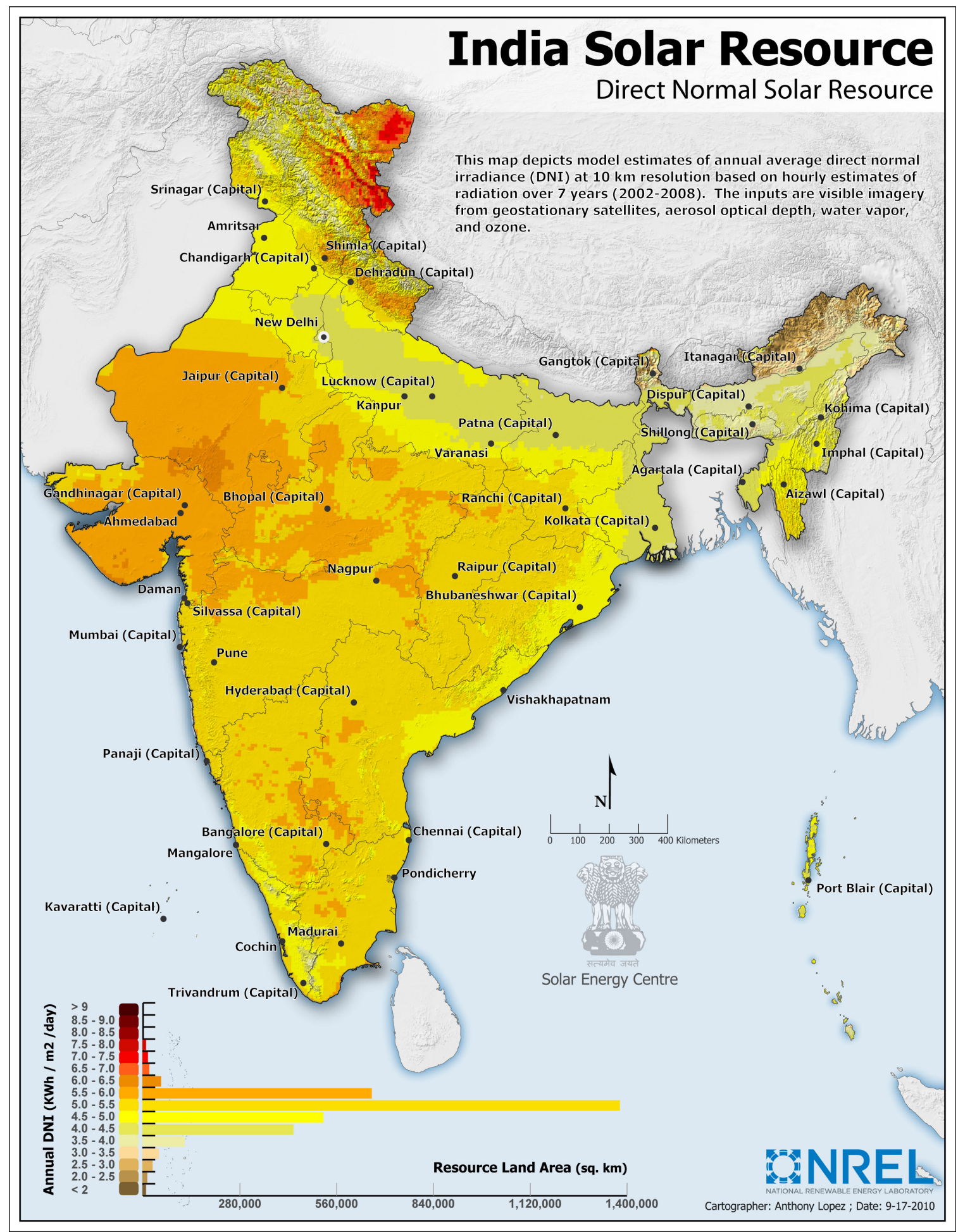

Figure 4-2. India's DNI resource at $10 \mathrm{~km}$ resolution

A recent study by the German Aerospace Center ${ }^{218}$ estimated the potential for CSP in several countries including India. This analysis used the NASA SSE 6.0 DNI dataset, with a spatial resolution of $100 \mathrm{~km}$ and remote sensing data at $1 \mathrm{~km}$ spatial resolution, to exclude land areas unsuitable for CSP development, including land with resource levels below

\footnotetext{
${ }^{218}$ Trieb, F.; Shillings, C.; O’Sullivan, M.; Pregger, T.; Hoyer-Klick, C. "2009: Global Potential of Concentrating Solar Power." SolarPaces Conference Berlin.

http://www.dlr.de/tt/en/Portaldata/41/Resources/dokumente/institut/system/projects/reaccess/DNI-Atlas-SPBerlin 20090915-04-Final-Colour.pdf. Accessed October 2010.
} 
$2,000 \mathrm{kWh} / \mathrm{m}^{2} /$ year $\left(5.48 \mathrm{kWh} / \mathrm{m}^{2} /\right.$ day $)$, settlement areas, steeply sloping land, and agricultural areas. Table 4-1 shows estimated land area appropriate for CSP development and estimated generation potential on these lands assuming a parabolic trough system. This analysis estimates that CSP could generate almost 11,000 TWh per year in India.

Table 4-1. India: Estimated Land Area Suitable for CSP Development and Generation Potential ${ }^{219}$

\begin{tabular}{|c|c|c|}
\hline $\begin{array}{c}\text { DNI Class } \\
\text { (kWh/m²/year) }\end{array}$ & $\begin{array}{l}\text { Land Area Suitable } \\
\text { for CSP } \\
\text { Development }\left(\mathrm{km}^{2}\right)\end{array}$ & $\begin{array}{c}\text { CSP Generating } \\
\text { Potential (TWh/year) }\end{array}$ \\
\hline $2,000-2,099$ & 83,522 & 7,893 \\
\hline $2,100-2,199$ & 11,510 & 1,140 \\
\hline $2,200-2,299$ & 5,310 & 550 \\
\hline $2,300-2,399$ & 7,169 & 774 \\
\hline $2,400-2,499$ & 3,783 & 426 \\
\hline $2,500-2,599$ & 107 & 13 \\
\hline $2,600-2,699$ & 976 & 119 \\
\hline $2,700-2,800+$ & 120 & 15 \\
\hline Total & 112,497 & 10,930 \\
\hline
\end{tabular}

\subsubsection{Concentrating Solar Power Projects in Planning Stages}

In the private sector, concentrating solar companies are beginning to develop a market presence in India. Areva Renewables, for example, a French company that offers CSP solutions, recently set up a partnership with the Indian companies L\&T and Bharat Forge for engineering support and supply chain management. ${ }^{220}$ Bright Source Energy, a U.S.-based solar thermal company, partnered with the French conglomerate Alstom, bringing an investment of INR 2.78 billion (USD 55 million) to the solar thermal market in India. Indian company Cargo Power and Infrastructure, a part of Cargo Motors, claimed to be the first CSP developer with a PPA in hand. ${ }^{221}$

Indian company ACME has a licensing agreement with U.S.-based eSolar, a manufacturer of modular CSP systems. Their first project, a $10 \mathrm{MW}$ plant in Bikaner, Rajasthan, is in the advanced stage of installation and is expected to generate power in late 2010 . $^{22}$

NTPC, India's largest power generation company, has two CSP plants in development: a 15 MW plant in Rajasthan and a 25 MW plant in Uttar Pradesh. 223

Approved CSP projects in Gujarat ${ }^{224}$ and Rajasthan, ${ }^{225}$ shown in Table 4-2, total $351 \mathrm{MW}$ and $30 \mathrm{MW}$, respectively.

\footnotetext{
${ }^{219}$ Adapted from Trieb, F.; Shillings, C.; O’Sullivan, M.; Pregger, T.; Hoyer-Klick, C. “2009: Global Potential of Concentrating Solar Power." SolarPaces Conference Berlin.

http://www.dlr.de/tt/en/Portaldata/41/Resources/dokumente/institut/system/projects/reaccess/DNI-Atlas-SPBerlin_20090915-04-Final-Colour.pdf. Accessed October 2010.

${ }^{220}$ The Hindu Business Line. TERI Newswire, Vol. 16., No. 8, 16-31 April 2010; p. 8.

${ }^{221}$ The Hindu Business Line. TERI Newswire, Vol. 16., No. 10, 16-31 May 2010.

${ }^{222}$ ACME. "Solar Thermal Technology." http://www.acme.in/solar-thermal-technology.asp?links=13a. Accessed August 2010.

${ }^{223}$ NTPC. "Foray into Renewable Energy."

https://www.ntpc.co.in/index.php?option=com content\&view=article\&id=206\&lang=en. Accessed August 2010.

${ }^{224}$ Gujarat Energy Development Agency. http://www.geda.org.in/pdf/solar_allotment_webnote.pdf. Accessed September 2010 .
} 
Table 4-2. Approved CSP Projects in Gujarat and Rajasthan

\begin{tabular}{|c|c|c|}
\hline Company & $\begin{array}{c}\text { Approved CSP Project } \\
\text { Capacity in Gujarat (MW) }\end{array}$ & $\begin{array}{c}\text { Approved CSP Project } \\
\text { Capacity in Rajasthan (MW) }\end{array}$ \\
\hline Acme Telepower & $\overline{446}$ & $\overline{10}$ \\
\hline Adani Power & 40 & \\
\hline Cargo Motors & 25 & \\
\hline Electrotherm & 40 & \\
\hline Abengoa & 40 & \\
\hline IDFC & 10 & \\
\hline KG Design Services & 10 & \\
\hline Sun Borne Energy & 50 & \\
\hline NTPC & 50 & \\
\hline Welspun Urja & 40 & \\
\hline Entegra & & 10 \\
\hline $\begin{array}{l}\text { Shri Rangam Brokers and } \\
\text { Holdings }\end{array}$ & & 10 \\
\hline Total & 351 & 30 \\
\hline
\end{tabular}

\subsubsection{Existing Policies, Measures, and Local Regulations}

In the past, there were several policy initiatives to establish CSP power generation in India, though to date there are no operational CSP plants. The failure of these initiatives is attributed to insufficient incentives and the historical absence of developers and EPC providers in the global CSP market. During the Tenth Plan, there was a goal to establish $140 \mathrm{MW}$ of CSP; ${ }^{226}$ however, no grid-interactive projects were built in that time. Under the Eleventh Plan, India's central government initially targeted $50 \mathrm{MW}$ of solar power, which was to include both CSP and PV. CSP development was to be supported by a preferential tariff offered by MNRE of up to INR 10 (USD 0.20) per kWh for electricity from solar thermal power plants. ${ }^{227}$ The system capacity under this scheme was to be between $1 \mathrm{MW}$ and $10 \mathrm{MW}$ per state and 50 MW total. The tariff was to be fixed for a period of 10 years. ${ }^{228}$ Now, however, the main push for the development of CSP is expected to come from JNNSM.

\subsubsection{National Solar Mission for Concentrating Solar Power}

With JNNSM, the government will work to create a favorable policy environment for solar thermal manufacturing. The target for Phase 1 (2010-2013) is to establish the technology and set up $500 \mathrm{MW}$ of grid-connected CSP. Since CSP projects have a long gestation period, the entire allocation will be decided upon in financial year 2010-2011. Subsequent phases will attempt to ramp up capacity and achieve economies of scale by aiming for 10,000 MW of grid-connected CSP by $2022 .^{229}$

In February 2010, the CERC announced a feed-in tariff for financial year 2010-2011 of INR 15.3 (USD 0.31) for CSP, which will be revised annually, and declared that PPAs have a

\footnotetext{
${ }^{225}$ Rajastan Renewable Energy Corporation Ltd. "Note on Solar Energy Power Plants in Rajasthan." 2010. www.rrecl.com/Note\%20on\%20Solar\%20Energy.pdf. Accessed August 2010.

${ }^{226}$ Government of India Planning Commission. "Eleventh Five Year Plan 2007-12: Volume III Agriculture, Rural Development, Industry, Services, and Physical Infrastructure.” p. 414, http://planningcommission.nic.in/plans/planrel/fiveyr/11th/11_v3/11th_vol3.pdf. Accessed August 2010. ${ }^{227}$ REEEP. "Policy and Regulatory Review-Special Report on India and Indian States, 2010." http://www.reep.org/file upload/296 tmpphpdxs0Zs.pdf. Accessed September 2010.

${ }^{228}$ REEEP. "Policy and Regulatory Review-Special Report on India and Indian States, 2010." http://www.reep.org/file upload/296 tmpphpdxs0Zs.pdf. Accessed September 2010.

${ }^{229}$ MNRE. National Solar Mission. Guidelines for New Grid Connected Solar Power Projects, July 2010. http://www.mnre.gov.in/pdf/jnnsm-gridconnected-25072010.pdf. Accessed October 2010.
} 
validity of 25 years. $^{230}$ If total applications for projects (including PV and CSP) in Phase 1 exceed the target of $500 \mathrm{MW}$, projects will be selected in a process of reverse bidding. ${ }^{231}$

In Phase 1, the minimum project size is $5 \mathrm{MW}$ and the maximum size is $100 \mathrm{MW}$. A promoter can apply for several projects, but overall, the combined applications may not exceed $100 \mathrm{MW}$ for each promoter. The promoter needs to demonstrate a net worth of INR 30 million (USD 600,000) per MW for the first $20 \mathrm{MW}$ and INR 20 million (USD 400,000) for each further MW. ${ }^{232}$

Projects will be connected to the grid at $33 \mathrm{kV}$. Plants must use a technology that has been in operation for a period of at least one year or for which financial closure of a commercial plant has already been obtained. At least $30 \%$ of the value of the project components (excluding land) has to be obtained from India. Power evacuation will be provided by the state utility. ${ }^{233}$

The promoter will have to pay a non-refundable processing fee of INR 100,000 (USD 2,000), a bid bond [on a graded scale between INR 10,000 (USD 200) and INR 50,000 (USD 1,000) per MW, which rises as the offered tariff lowers], an EMD in the form of a bank guarantee of INR 2 million (USD 40,000) per MW, and later, a performance bank guarantee of INR 3 million (USD 60,000) per MW at the time of signing the PPA. ${ }^{234}$

A project shall achieve financial closure within 180 days from the date of signing a PPA, and all bank guarantees need to be valid for a period of 34 months from the date of signing a PPA. $^{235}$

\subsubsection{State Policies}

In addition to JNNSM, the state of Gujarat has its own CSP policy. In accordance with the Gujarat Solar Power Policy of 2009, the Gujarat Electricity Regulatory Commission set a levelized fixed tariff for solar thermal systems greater than $5 \mathrm{MW}$ to be INR 11 (USD 0.22) per $\mathrm{kWh}$ for the first 12 years and INR 4 (USD 0.08) per kWh for the remaining 13 years. ${ }^{236}$ The scheme will provide these incentives for solar thermal systems installed and commissioned between 2009 and 2014, for a statewide maximum of $500 \mathrm{MW}$ (of PV and solar thermal combined). There is a control period of two years, which means that eligible projects must be commissioned by March 2012.

Power generated from CSP is exempt from electricity duty. The tariffs have already taken into account the $80 \%$ accelerated depreciation tax benefit and would be revised accordingly for those projects that are not availing the tax scheme. In the latter case, projects will be

\footnotetext{
${ }^{230}$ CERC. Tariff Order. Petition No.53/2010. 26 February 2010. http://cercind.gov.in/2010/ORDER/February2010/53-2010 Suo-Motu RE_Tariff_Order_FY2010-11.pdf. Accessed August 2010

${ }^{231}$ MNRE. National Solar Mission. Guidelines for New Grid Connected Solar Power Projects, July 2010. http://www.mnre.gov.in/pdf/jnnsm-gridconnected-25072010.pdf. Accessed October 2010.

${ }^{232}$ MNRE. National Solar Mission. Guidelines for New Grid Connected Solar Power Projects, July 2010. http://www.mnre.gov.in/pdf/jnnsm-gridconnected-25072010.pdf. Accessed October 2010.

${ }^{233}$ MNRE. National Solar Mission. Guidelines for New Grid Connected Solar Power Projects, July 2010. http://www.mnre.gov.in/pdf/jnnsm-gridconnected-25072010.pdf. Accessed October 2010.

${ }^{234}$ MNRE. National Solar Mission. Guidelines for New Grid Connected Solar Power Projects, July 2010. http://www.mnre.gov.in/pdf/jnnsm-gridconnected-25072010.pdf. Accessed October 2010.

${ }^{235}$ MNRE. National Solar Mission. Guidelines for New Grid Connected Solar Power Projects, July 2010. http://www.mnre.gov.in/pdf/jnnsm-gridconnected-25072010.pdf. Accessed October 2010.

${ }^{236}$ Gujarat Energy Development Agency. Tariff Order, 29 January 2010, p. 29.

http://www.gercin.org/docs/Orders/Nonconv\%20orders/Year\%202010/Order\%202-2010.pdf. Accessed September 2010.
} 
subject to a slightly higher state tariff but can avail the INR 0.50 (USD 0.01) per kWh GBI offered by MNRE.

\subsubsection{Technology Development}

There is no indigenous capacity for solar thermal power plants, although some manufacturing capacity exists for low-temperature solar collectors. JNNSM announced that incentive packages similar to SIPS (for PV) would be introduced for advanced collectors at low temperatures as well as for CSP collectors at medium and high temperatures. ${ }^{237}$

Under JNNSM, it is envisaged that MNRE will set up demonstration plants for different solar thermal technologies: a 50-100 MW solar-thermal power plant with a storage capacity of 4-6 hours; a $100 \mathrm{MW}$ solar-thermal power plant with parabolic trough technology; a 100-150 MW hybrid plant, which combines solar power with power from coal or biomass; and a $20-50 \mathrm{MW}$ solar-thermal plant with molten salt or steam as a heating medium. ${ }^{238}$

\subsubsection{Success Stories from the International Community and Potential Opportunities for India}

According to studies done by the German Aerospace Center, CSP on only 0.003 of the world's deserts (i.e., $90,000 \mathrm{~km}^{2}$ ) can provide 18,000 TWh/year, which is sufficient for global consumption. ${ }^{239}$ However, globally, the use of large-scale CSP for the generation of electricity is still a niche product. Although the technology has been around for a long time, there are currently very few commercially viable plants and capable project developers.

The most famous CSP installation is the set of nine plants totaling $354 \mathrm{MW}$ constructed by Solar Energy Generation Systems in the 1980s in the Mojave Desert in California, United States. Currently in the United States, there are two more CSP plants with a cumulative capacity of $65 \mathrm{MW}$ in operation. ${ }^{240}$ In Spain, the Andasol 1 and 2 projects with a cumulative capacity of $100 \mathrm{MW}$ were constructed in 2008 and 2009, respectively, by Solar Millennium. ${ }^{241}$

The DESERTEC Foundation, an initiative of the Club of Rome, is aspiring to tap solar energy in the Sahara Desert to cater to the energy needs of Europe, the Middle East, and Africa. ${ }^{242}$ DESERTEC envisions widespread CSP deployment in North Africa and has investigated opportunities for high-voltage direct current transmission lines to carry power produced to southern Europe.

Given the high irradiation data and the endemic power deficit in India, as well as the government's dedication to developing CSP, the Indian market presents very attractive opportunities for strategic investors willing to develop the technology further and make it marketable in India. There is also a significant opportunity in producing equipment like concentrating mirrors or receiving tubes in India in order to bring down the cost of projects.

\footnotetext{
${ }^{237}$ MNRE. "Jawaharlal Nehru National Solar Mission: Towards Building SOLAR INDIA.” p. 6. http://mnre.gov.in/pdf/mission-document-JNNSM.pdf. Accessed August 2010.

${ }^{238}$ MNRE. "Jawaharlal Nehru National Solar Mission: Towards Building SOLAR INDIA.” p. 6-7. http://mnre.gov.in/pdf/mission-document-JNNSM.pdf. Accessed August 2010.

${ }^{239}$ DESERTEC Foundation. "Red Paper." http://www.desertec.org/fileadmin/downloads/desertecfoundation redpaper 3rd-edition english.pdf. Accessed August 2010.

${ }^{240}$ NREL. "U.S. Parabolic Trough Power Plant Data."

http://www.nrel.gov/csp/troughnet/power_plant_data.html. Accessed August 2010.

${ }^{241}$ Solar Millennium. "The Construction of the Andasol Power Plants."

http://www.solarmillennium.de/front content.php?idart=155\&lang=2. Accessed August 2010.

${ }^{242}$ DESERTEC Foundation. http://www.desertec.org/en/concept/technologies/. Accessed August 2010.
} 
International companies such as Areva and eSolar, who have advanced thermal technology, are expected to be successful in the Indian market. ${ }^{243}$ Siemens, who acquired SOLEL, recently unveiled the latest CSP solar receiver, which will increase the output of parabolic trough solar thermal plants. ${ }^{244}$ The company plans to market this to India, among other countries, where there is a potentially high market for CSP. ${ }^{245}$

\subsection{Solar Water Heating}

SWHs have widespread potential in India including in the residential, commercial and industrial sectors. MNRE has estimated the total SWH potential to be approximately 40 million $\mathrm{m}^{2}$ of collector area, and as of June 2010, installations had reached just over 3.5 million $\mathrm{m}^{2}$ of collector area. The targets for 2012 and 2022 are to reach collector area of 5 million $\mathrm{m}^{2}$ and 20 million $\mathrm{m}^{2}$, respectively. Government support for SWH deployment is available as capital and interest subsidies. The Indian government is also supporting market development and awareness building through capacity building and outreach activities.

\subsubsection{Global Solar Water Heating Capacity}

In 2009, the worldwide existing cumulative solar hot water and heating capacity increased by $21 \%$ to reach an estimated 180,000 thermal MW (figure excludes unglazed swimming pool heating). ${ }^{246}$ In 2008 , approximately $70.5 \%$ of existing global SWH capacity $(149,000$ thermal MW) was in China, followed by European Union (EU) (12.3\%), Turkey (5.0\%), Japan $(2.8 \%)$, and Israel $(1.7 \%)$. The Indian share was $1.2 \%$.

\footnotetext{
${ }^{243}$ Walet, L. “Foreign Companies Take a Shine to India’s \$70 Billion Solar Programme.” Mint 18 June 2010. http://www.livemint.com/2010/06/17215210/Foreign-companies-take-shine-t.html?atype=tp. Accessed August 2010.

${ }^{244}$ Siemens. "Siemens to Supply Solar Receivers for New Solar Power Plant in Spain.” 24 March 2010, http://www.siemens.com/press/en/pressrelease/?press=/en/pressrelease/2010/renewable_energy/ere201003049.h tm. Accessed August 2010.

${ }^{245}$ Siemens. "Siemens to Supply Solar Receivers for New Solar Power Plant in Spain." 24 March 2010, http://www.siemens.com/press/en/pressrelease/?press=/en/pressrelease/2010/renewable energy/ere201003049.h tm. Accessed August 2010.

${ }^{246}$ REN21. "Renewables 2010 Global Status Report.” Paris: REN21 Secretariat. 2010. http://www.ren21.net/globalstatusreport/REN21 GSR 2010 full.pdf. Accessed October 2010.
} 
Table 4-3. SWH Existing Capacity, Top 10 Countries (2008) ${ }^{247}$

\begin{tabular}{|l|l|l|}
\hline \multicolumn{1}{|c|}{ Country } & $\begin{array}{c}\text { SWH Existing } \\
\text { Capacity [MWth] }\end{array}$ & $\begin{array}{c}\text { SWH Existing } \\
\text { Capacity }\end{array}$ \\
\hline China & 105,045 & $70.5 \%$ \\
\hline EU & 18,327 & $12.3 \%$ \\
\hline Turkey & 7,450 & $5.0 \%$ \\
\hline Japan & 4,172 & $2.8 \%$ \\
\hline Israel & 2,533 & $1.7 \%$ \\
\hline Brazil & 2,384 & $1.6 \%$ \\
\hline United States & 1,937 & $1.3 \%$ \\
\hline India & 1,788 & $1.2 \%$ \\
\hline Australia & 1,341 & $0.9 \%$ \\
\hline South Korea & 1,043 & $0.7 \%$ \\
\hline Others & 2,980 & $2.0 \%$ \\
\hline Total & $\mathbf{1 4 9 , 0 0 0}$ & $\mathbf{1 0 0} \%$ \\
\hline
\end{tabular}

\subsubsection{Solar Water Heating in India}

MNRE estimates that a 100-liter SWH, an appropriate size for domestic use, could save $1,500 \mathrm{kWh}$ of electricity per year. At an energy cost of INR 5 (USD 0.10 ) per $\mathrm{kWh}$, the savings are INR 7,500 (USD 150). MNRE also estimates that each 1,000 100-liter SWHs deployed can shave $1 \mathrm{MW}$ of peak power demand. ${ }^{248}$

As of 1989, the total collector area of installed SWH in India was approximately $119,000 \mathrm{~m}^{2}$.

${ }^{249}$ Between 1995 and 2008, the annual growth rate in SWH installations was $16.8 \% .{ }^{250} \mathrm{At}$ the end of 2002, India's total installed collector area was $680,000 \mathrm{~m}^{2},{ }^{251}$ and this reached 2.7 million $\mathrm{m}^{2}$ by the end of $2008 .{ }^{252}$ By the end of 2009 , the total installed collector area had reached approximately 3.4 million $\mathrm{m}^{2}{ }^{253}$ Approximately 0.5 million $\mathrm{m}^{2}$ of this value is from sales between April and December 2009. ${ }^{254}$

\footnotetext{
${ }^{247}$ REN21. "Renewables 2010 Global Status Report.” Paris: REN21 Secretariat. 2010. http://www.ren21.net/globalstatusreport/REN21 GSR 2010 full.pdf. Accessed October 2010.

${ }^{248}$ MNRE. “A Brief on Solar Water Heating Systems.” http://www.mnre.gov.in/Solar-water-heaters/briefswhs.pdf. Accessed October 2010.

${ }^{249}$ OPET-TERI \& HECOPET. "Status of Solar Thermal Technologies and Markets in India and Europe-An OPET International Action 'Enhancement Of Market Penetration Of Solar Thermal Technologies.”” p. 5. http://www.teriin.org/opet/reports/solarthermal.pdf. Accessed October 2010.

${ }^{250}$ GKS. "Solar Water Heaters in India: Market Assessment Studies and Surveys for Different Sectors and Demand Segments.” 20 January 2010. http://mnre.gov.in/pdf/greentech-SWH-MarketAssessment-report.pdf. Accessed August 2010.

${ }^{251}$ MNRE. Annual Report 2002-03. http://mnre.gov.in/annualreport/2002_2003_English/ch4_pg2.htm. Accessed October 2010.

${ }^{252}$ MNRE. Annual Report 2008-09. http://mnre.gov.in/annualreport/2008-09EN/renewable-energy-for-urbanIndustrial.htm. Accessed October 2010.

${ }^{253}$ MNRE. Annual Report 2009-10. Table 1.1, No. 14. http://mnre.gov.in/annualreport/200910EN/Chapter1/chapter1 1.htm. Accessed August 2010.

${ }^{254}$ MNRE. Annual Report 2009-10. Table 1.1, No. 14. http://mnre.gov.in/annualreport/200910EN/Chapter1/chapter1_1.htm. Accessed August 2010.
} 


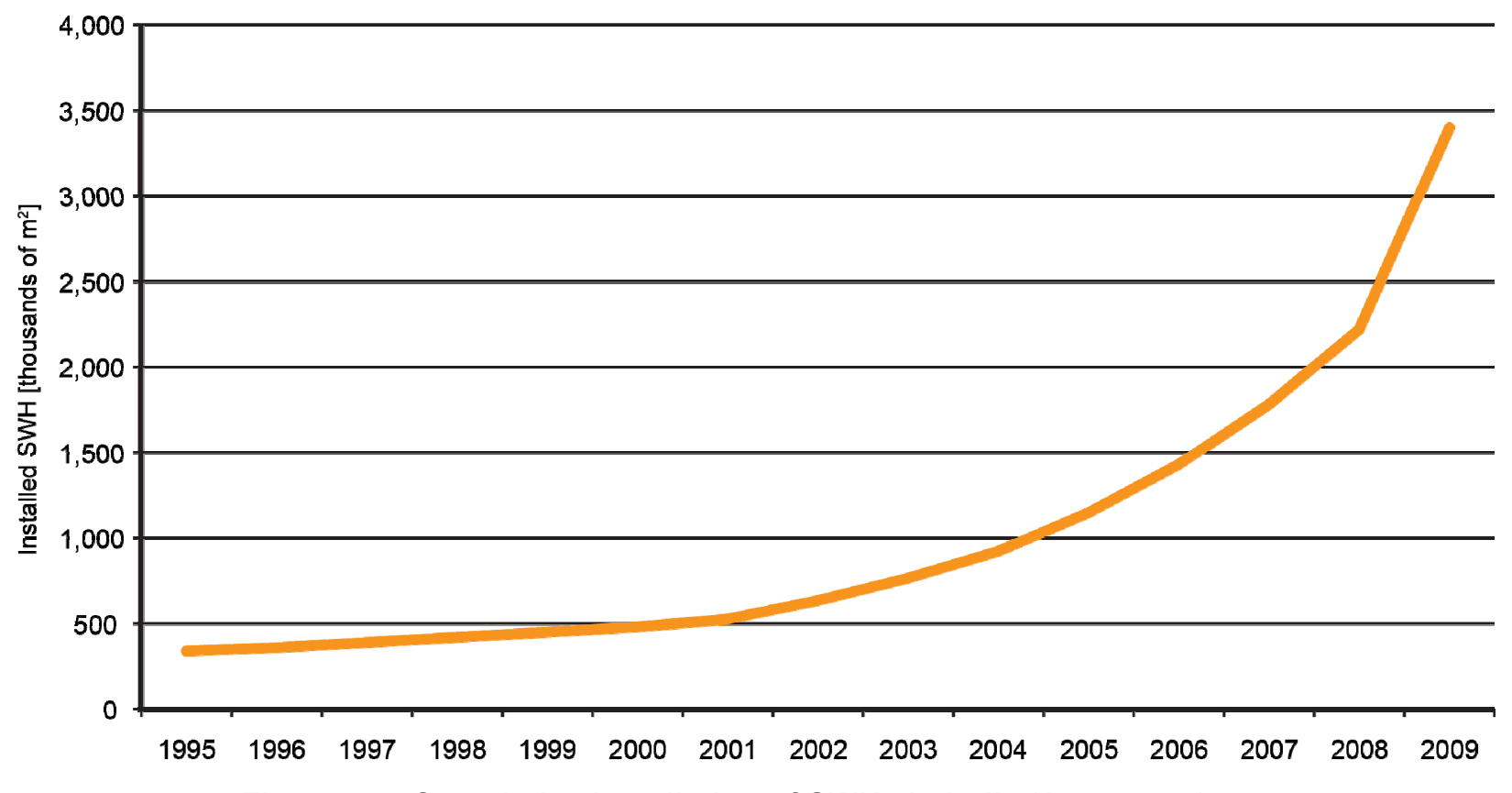

Figure 4-3. Cumulative installation of SWHs in India (1995-2009)

At the end of June 2010, India's cumulative SWH installations had reached over 3.5 million $\mathrm{m}^{2}$ of collector area, ${ }^{255}$ less than $10 \%$ of the estimated techno-economic potential of approximately 40 million $\mathrm{m}^{2}$ of SWH collector area. ${ }^{256}$ India's current installations work out to approximately $3 \mathrm{~m}^{2}$ of collector area per 1,000 people. In Israel where $80 \%$ of the households use SWH for heating their water, the SWH collector area is approximately $500 \mathrm{~m}^{2}$ per 1,000 people. $^{257}$

Present installations are concentrated (65\%) in two states - Karnataka and Maharashtra - and more than $95 \%$ of households in India with SWH are located in urban areas. A 2010 SWH market assessment estimates that $85 \%$ of installed SWH are functioning. ${ }^{258}$

As seen in Table 4-4, the SWH installations in India are distributed across the following market-segments: households (residential sector) in both urban and rural areas, commercial and institutional buildings (e.g., hotels, hospitals, hostels, and religious complexes), and industries.

\footnotetext{
${ }^{255}$ MNRE. Annual Report 2009-10. http://mnre.gov.in/annualreport/200910EN/Chapter\%205/chapter\%205 1.htm. Accessed October 2010.

256 MNRE. Annual Report 2009-10. http://mnre.gov.in/annualreport/200910EN/Chapter\%205/chapter\%205 1.htm. Accessed October 2010.

${ }^{257}$ REN21. "Renewables 2010 Global Status Report.” Paris: REN21 Secretariat. 2010. http://www.ren21.net/globalstatusreport/REN21_GSR 2010 full.pdf. Accessed October 2010.

${ }^{258}$ GKS. "Solar Water Heaters in India: Market Assessment Studies and Surveys for Different Sectors and Demand Segments." 20 January 2010. http://mnre.gov.in/pdf/greentech-SWH-MarketAssessment-report.pdf. Accessed August 2010.
} 
Table 4-4. Estimated Breakdown: Functional SWH Installation Through December 31, $2009^{259}$

\begin{tabular}{|l|cc|}
\hline \multicolumn{1}{|c|}{ Sector } & $\begin{array}{c}\text { Percentage } \\
\text { Distribution }\end{array}$ & million $\mathbf{~ m}^{\mathbf{2}}$ \\
\hline Residential & $80 \%$ & 2.108 \\
\hline Hotels & $6 \%$ & 0.158 \\
\hline Hospitals & $3 \%$ & 0.079 \\
\hline Industries & $6 \%$ & 0.158 \\
\hline $\begin{array}{l}\text { Other (Railway, Defense, } \\
\text { Hostels, Religious Places, } \\
\text { Other) }\end{array}$ & $5 \%$ & 0.132 \\
\hline Total & $\mathbf{1 0 0 \%}$ & $\mathbf{2 . 6 3 5}$ \\
\hline
\end{tabular}

\subsubsection{Households}

In households, hot water is required for bathing, cleaning utensils, washing clothes, cooking, and preparation of cattle feed. The majority of rural households in the country use traditional biomass fuels for most purposes, including heating water. Urban households tend to use liquefied petroleum gas (LPG) and electricity for heating water with the percentage of households using electric water heaters being quite low.

The main use of household SWH is for bathing. The demand of hot water varies significantly across different regions, from 4 months per year in warmer regions to 9 months in colder regions. $^{260}$ The highest requirement of hot water in rural households is in the cold region of the country, mostly in the Himalayan states. However, most households with SWH are in non-rural and warmer areas. Only 5\% of households with SWH are located in rural areas, and those are mostly in high-income rural households in parts of states including Himachal Pradesh and Kerala. The barriers to increased use of SWH systems in rural areas have been identified as:

- High initial cost of the system.

- Long payback period as the fuel replaced is low-cost biomass fuel.

- Lack of piped water supply.

- Absence of SWH supply chain.

- Difficulty in installing conventional SWH systems on sloping roofs made of metal sheets or thatch. ${ }^{261}$

\subsubsection{Commercial and Institutional Buildings}

In hotels, there is a year-round demand for hot water. The number of hotels with SWH systems installed has increased as a means to reduce the use of expensive petroleum fuels and

\footnotetext{
${ }^{259}$ GKS. "Solar Water Heaters in India: Market Assessment Studies and Surveys for Different Sectors and Demand Segments." 20 January 2010. http://mnre.gov.in/pdf/greentech-SWH-MarketAssessment-report.pdf. Accessed August 2010. Note this report assumes $85 \%$ of installed collector area was functioning at the time of their investigation, which equates to a total functional installed collector area of 3.1 million $\mathrm{m}^{2}$, which differs from the MNRE official estimate of total installed collector area through 2009 of 3.4 million m².

${ }^{260}$ Greentech Knowledge Solutions Ltd. "Solar Water Heaters in India: Market Assessment Studies and Surveys for Different Sectors and Demand Segments.” 20 January 2010. http://mnre.gov.in/pdf/greentech-SWHMarketAssessment-report.pdf. Accessed August 2010.

${ }^{261}$ Greentech Knowledge Solutions Ltd. "Solar Water Heaters in India: Market Assessment Studies and Surveys for Different Sectors and Demand Segments.” 20 January 2010. http://mnre.gov.in/pdf/greentech-SWHMarketAssessment-report.pdf. Accessed August 2010.
} 
electricity. Use of SWH for supplying hot water in institutional buildings such as hospitals and hostels has lagged behind the technology adoption observed in the hotel industry.

\subsubsection{Industries}

Hot water and steam are used in a variety of industries including textile, dairy, and pulp and paper. The potential applications of SWH in the industries vary from pre-heating boiler feed water to a temperature of $60^{\circ}-80^{\circ} \mathrm{C}$, heating process hot water up to $<100^{\circ} \mathrm{C}$, and canteen applications. ${ }^{262}$

\subsubsection{Existing Policies, Measures, and Local Regulations}

MNRE has implemented a SWH program to accelerate development and deployment of SWH in India through a combination of financial and promotional incentives. In addition to capital subsidies for SWH systems, this program provides interest subsidies. ${ }^{263}$

MNRE is also implementing a UNDP/UNEP/GEF project titled "Global Solar Water Heating Market Transformation Strengthening Initiative” under UNDP's India Country Program, which is designed to support SWH market development. The overarching objective of the $\mathrm{UNDP} / \mathrm{UNEP} / \mathrm{GEF}$ SWH project is to build on and strengthen the MNRE National Programme and create markets and widespread demand for SWH in different sectors, building awareness in sectors where SWH have application but have not experienced widespread adoption and raising capacity building to increase the quality of the end-use product. This project targets cumulative SWH installations of 10 million $\mathrm{m}^{2}$ of collector area in India by $2012 .^{264}$

SWHs are an integral part of JNNSM, which targets 20 million $\mathrm{m}^{2}$ of SWH collectors by 2022. JNNSM targets 3.45 million $\mathrm{m}^{2}$ of new installations during Phase I to reach 7 million $\mathrm{m}^{2}$ of installed collector area by 2013 , an additional 8 million $\mathrm{m}^{2}$ installed during Phase 2 ending 2017, and an additional 5 million $\mathrm{m}^{2}$ during Phase 3 to reach the 20 million $\mathrm{m}^{2}$ target by 2022 .

SWH systems have also been incorporated in the new national building code. SWH systems are included in GRIHA rating system ${ }^{265}$ for green buildings and energy conservation building codes. An energy labelling scheme similar to the star rating scheme for air conditioners and refrigerators is also planned to promote efficient SWHs.

\footnotetext{
${ }^{262}$ Greentech Knowledge Solutions Ltd. "Solar Water Heaters in India: Market Assessment Studies and Surveys for Different Sectors and Demand Segments.” 20 January 2010. http://mnre.gov.in/pdf/greentech-SWHMarketAssessment-report.pdf. Accessed August 2010.

${ }^{263}$ Greentech Knowledge Solutions Ltd. "Solar Water Heaters in India: Market Assessment Studies and Surveys for Different Sectors and Demand Segments.” 20 January 2010. p. 35. http://mnre.gov.in/pdf/greentech-SWHMarketAssessment-report.pdf. Accessed August 2010.

${ }^{264}$ UNDP. Global Solar Water Heating Market Transformation and Strengthening Initiative. 2009. http://www.undp.org.in/sites/default/files/Global-Solar-Water-Heating.pdf. Accessed October 2010. ${ }^{265}$ GRIHA, an acronym for Green Rating for Integrated Habitat Assessment, is the national rating system of India. This green building rating system has been developed by TERI, after a thorough study and understanding the current internationally accepted green building rating systems and the prevailing building practices in India. The GRIHA rating system consists of 34 criteria categorized under various sections such as Site Selection and Site Planning, Building Operation and Maintenance, and Innovation. For more information, see http://www.grihaindia.org/. Accessed August 2010.
} 


\section{Small Hydro}

\section{Chapter Overview}

The estimated potential for small hydro in India of 15,000 $\mathrm{MW}^{266}$ suggests that it can make a significant contribution to India's power supply, especially in remote areas where alternative supply solutions face many challenges. For these reasons, the further development of small hydro is one of the focal areas of MNRE, who wants to concentrate on reducing the capital costs and enhancing the reliability, plant load factors, and average plant lifetimes. The Indian government aims to develop half of the identified potential in the next 10 years and is supporting small-hydro deployment through capital subsidies and preferential tariffs. As of March 2010, a total of 2,735 MW of grid-connected small hydropower has been installed, contributing about $16.2 \%$ to India's total grid interactive renewable power. ${ }^{267}$

\subsection{Resource/Technological Potential}

In India, small hydro plants have a capacity of $25 \mathrm{MW}$ or less and are further subdivided into micro (100 kW or less), mini (between $100 \mathrm{~kW}$ and $2 \mathrm{MW}$ ), and small (between $2 \mathrm{MW}$ and $25 \mathrm{MW})$. Large hydropower is not covered in this paper. Small hydropower plants are generally run-of-river, with only small amounts of water stored, if any. These projects are considered environmentally benign, particularly when compared to large hydro plants with storage reservoirs, which can cause habitat destruction and community displacement. ${ }^{268}$

MNRE has estimated the potential for small hydro in India at 15,386 MW for 5,718 prospective plant sites. ${ }^{269}$ Of this total potential, over $42 \%(6,592 \mathrm{MW})$ is in four northern mountainous states: Himachal Pradesh, Uttarakhand, Jammu and Kashmir, and Arunachal Pradesh. The state-level potential estimates from MNRE are shown in Table 5-1 along with total installed capacity and projects in progress as of December $31,2009 .{ }^{270}$ The current estimate of total small hydro potential increased from the 14,292 MW estimate published in MNRE's 2008-2009 Annual Report, ${ }^{271}$ which notes that efforts to identify additional prospective sites are ongoing in both the public as well as the private sector.

\footnotetext{
${ }^{266}$ MNRE. Annual Report 2009-10. http://mnre.gov.in/annualreport/2009-10EN/index.htm. Accessed July 2010. ${ }^{267}$ MNRE. "Achievements as of March 31, 2010." http://www.mnre.gov.in/achievements.htm. Accessed July 2010.

${ }^{268}$ Palsh, O. "Small Hydro Power: Technology and Current Status.” Renewable Sustainable Energy Rev.; Vol. 6, 2002; pp. 537-556.

${ }^{269}$ MNRE. Annual Report 2009-10. http://mnre.gov.in/annualreport/2009-10EN/index.htm. Accessed July 2010.

${ }^{270}$ MNRE. "Achievements as of March 31, 2010." http://www.mnre.gov.in/achievements.htm. Accessed July 2010.

${ }^{271}$ MNRE. Annual Report 2009-10. http://mnre.gov.in/annualreport/2009-10EN/index.htm. Accessed October 2010 .
} 
Table 5-1. Small Hydro Potential by Indian State, Number of Sites, Installed Capacity, Installed Projects, and Capacity Under Development as of December 31, $2009^{272}$

\begin{tabular}{|c|c|c|c|c|}
\hline State & $\begin{array}{c}\text { Number of } \\
\text { Prospective } \\
\text { Sites }\end{array}$ & $\begin{array}{c}\text { Total } \\
\text { Potential } \\
\text { Capacity } \\
\text { (MW) }\end{array}$ & $\begin{array}{l}\text { Projects } \\
\text { Installed } \\
\text { (MW) }\end{array}$ & $\begin{array}{c}\text { Projects in } \\
\text { Progress } \\
\text { (MW) }\end{array}$ \\
\hline Andaman \& Nicobar Islands & 7 & 7 & 5 & - \\
\hline Andhra Pradesh & 497 & 560 & 187 & 63 \\
\hline Arunachal Pradesh & 550 & 1,329 & 67 & 21 \\
\hline Assam & 119 & 239 & 27 & 15 \\
\hline Bihar & 95 & 213 & 55 & 3 \\
\hline Chhattisgarh & 184 & 993 & 19 & - \\
\hline Goa & 6 & 7 & 0 & - \\
\hline Gujarat & 292 & 197 & 7 & 5 \\
\hline Haryana & 33 & 110 & 69 & 5 \\
\hline Himachal Pradesh & 536 & 2,268 & 255 & 185 \\
\hline Jammu \& Kashmir & 246 & 1,418 & 129 & 6 \\
\hline Jharkhand & 103 & 209 & 4 & 35 \\
\hline Karnataka & 138 & 748 & 588 & 107 \\
\hline Kerala & 245 & 704 & 134 & 24 \\
\hline Madhya Pradesh & 299 & 804 & 71 & 20 \\
\hline Maharashtra & 255 & 733 & 221 & 67 \\
\hline Manipur & 114 & 109 & 5 & 3 \\
\hline Meghalaya & 101 & 230 & 31 & 2 \\
\hline Mizoram & 75 & 167 & 28 & 9 \\
\hline Nagaland & 99 & 189 & 29 & 4 \\
\hline Orissa & 222 & 295 & 64 & 4 \\
\hline Punjab & 237 & 393 & 128 & 29 \\
\hline Rajasthan & 66 & 57 & 24 & - \\
\hline Sikkim & 91 & 266 & 47 & 5 \\
\hline Tamil Nadu & 197 & 660 & 90 & 13 \\
\hline Tripura & 13 & 47 & 16 & - \\
\hline Uttar Pradesh & 251 & 461 & 25 & - \\
\hline Uttarakhand & 444 & 1,577 & 133 & 234 \\
\hline West Bengal & 203 & 396 & 98 & 79 \\
\hline Total & 5,718 & 15,386 & 2,556 & 938 \\
\hline
\end{tabular}

\subsection{Installed Capacity}

The Tenth Plan (2002-2007) targeted the installation of $600 \mathrm{MW}$ of small hydropower. During that period, $520 \mathrm{MW}$ was actually installed. This was significantly less than the 1,438 MW installed during the Ninth Plan (2002-2006). ${ }^{273}$ The Eleventh Plan has established

\footnotetext{
${ }^{272}$ MNRE. Annual Report 2009-10. http://mnre.gov.in/annualreport/2009-10EN/index.htm. Accessed July 2010.

${ }^{273}$ Government of India Planning Commission. "Eleventh Five Year Plan 2007-12: Agriculture, Rural Development, Industry, Services, and Physical Infrastructure.” New Delhi, India: Oxford University Press, 2008; p. 414. http://planningcommission.nic.in/plans/planrel/fiveyr/11th/11_v3/11th_vol3.pdf. Accessed July 2010.
} 
a target of 1,400 MW. ${ }^{274}$ The goal for the next 10 years is to harness half of the $15 \mathrm{GW}$ of identified potential. $^{275}$

Table 5-1 shows state-level installed capacity of small hydro plants and plants in progress. The state with the greatest amount of installed and in progress small hydro capacity in 2009 was Karnataka, totaling $695 \mathrm{MW}$, which is $93 \%$ of the identified potential in the state. Himachal Pradesh has $440 \mathrm{MW}$ of installed and in-progress small hydro plants, which is less than $20 \%$ of the estimated potential in this state. An additional 176.27 MW of small hydro capacity was added between January 1 and March 31, 2010, taking the total for financial year 2009-2010 to $305.27 \mathrm{MW}^{276}$

\subsection{Existing Policies, Measures, and Local Regulations}

Until 1989, all hydropower projects were under the administrative control of MoP and the CEA, while the responsibility for execution and maintenance was with the SEBs. Today MoP is involved only in hydropower projects larger than $25 \mathrm{MW}$, while MNRE is responsible for projects with station capacities of $25 \mathrm{MW}$ or less. ${ }^{277}$

Both the central government and the state governments provide incentives for the construction of small hydropower plants. MNRE proposed a new small hydro scheme in 2009-2010, which provides support in the form of capital subsidies to new plants between $100 \mathrm{~kW}$ and $25 \mathrm{MW}$ implemented by the state (see Table 5-2), new plants implemented by the private sector or non-governmental organizations (NGOs) (see Table 5-3), and R\&M of existing plants (see Table 5-4). ${ }^{278}$ Capital subsidies are also available for watermills and micro hydro projects up to $100 \mathrm{~kW}$. Watermill subsidies range between INR 35,000 (USD 700) and INR 110,000 (USD 2,200). Micro-hydro subsidies range from INR 40,000 (USD 800) to INR 100,000 (USD 2,000). In all cases, special category and northeastern states have a higher subsidy. The amounts are paid in installments, with the schedule of payments varying by the category of project. An additional financial incentive of INR 200,000 (USD 4,000) is available to identify potential sites for projects below $1 \mathrm{MW}$ and an additional INR 500,000 (USD 10,000) for projects between 1-25 MW.

\footnotetext{
${ }^{274}$ Government of India Planning Commission. "Eleventh Five Year Plan 2007-12: Agriculture, Rural Development, Industry, Services, and Physical Infrastructure." New Delhi, India: Oxford University Press, 2008; p. 414. http://planningcommission.nic.in/plans/planrel/fiveyr/11th/11_v3/11th_vol3.pdf. Accessed July 2010.

${ }^{275}$ MNRE. Annual Report 2009-10. http://mnre.gov.in/annualreport/2009-10EN/index.htm. Accessed July 2010. ${ }^{276}$ MNRE. "Achievements as of March 31, 2010." http://www.mnre.gov.in/achievements.htm. Accessed July 2010.

${ }^{277}$ Kesharwani, M.K. “Overview of Small Hydro Power Development in Himalayan Region.” Himalayan Small Hydropower Summit; 12-13 October 2006 in Dehradun; p. 51.

http://ahec.org.in/acads/HSHS/Presentations/Links/Technical\%20Papers/Overview\%20of\%20SHP\%20Develop ment/Mr\%20MK\%20Kesharwani Overview\%20of\%20SHP\%20Development.pdf. Accessed September 2010. ${ }^{278}$ MNRE. "Small Hydro Power Programme.” http://mnre.gov.in/adm-approvals/shp scheme.pdf. Accessed July 2010.
} 
Table 5-2. MNRE Support for New Small Hydro Projects Implemented by the State ${ }^{279}$

\begin{tabular}{|c|c|c|}
\hline Category & Projects $100-1,000 \mathrm{~kW}$ & 1-25 MW \\
\hline $\begin{array}{l}\text { Special category and } \\
\text { NE states }\end{array}$ & $\begin{array}{l}\text { INR 50,000/kW } \\
\text { (USD 1,000/kW) }\end{array}$ & $\begin{array}{c}\text { INR } 50 \text { million (USD } 1 \text { million) } \\
\text { for the first MW; INR } 5 \text { million } \\
\text { (USD 100,000) for each } \\
\text { additional MW }\end{array}$ \\
\hline Other states & $\begin{array}{l}\text { INR 25,000/kW } \\
\text { (USD 500/kW) }\end{array}$ & $\begin{array}{l}\text { INR } 25 \text { million (USD 500,000) } \\
\text { for the first MW; INR } 4 \text { million } \\
\text { (USD 80,000) for each } \\
\text { additional MW }\end{array}$ \\
\hline
\end{tabular}

Table 5-3. MNRE Support for New Small Hydro Projects Implemented by the Private Sector and NGOs $^{280}$

\begin{tabular}{|ccc|}
\hline Category & Projects $\mathbf{1 0 0 - 1 , 0 0 0 ~} \mathbf{k W}$ & $\mathbf{1} \mathbf{~ M W - 2 5 ~} \mathbf{M W}$ \\
\hline \hline $\begin{array}{c}\text { Special category and } \\
\text { NE states }\end{array}$ & INR 20,000/kW & INR 20 million (USD 400,000) \\
& (USD 400/kW) & for the first MW; INR 3 million \\
& & (USD 60,000) for each \\
& & additional MW \\
Other states & INR 12.5 million (USD \\
& INR 12,000/kW & 250,000) for the first MW; INR \\
& (USD 240/kW) & million (USD 40,000) for \\
& & each additional MW \\
\hline
\end{tabular}

Table 5-4. MNRE Scheme to Renovate and Modernize Existing Projects ${ }^{281}$

\begin{tabular}{|ccc|}
\hline Category & Projects 100-1,000 kW & 1-25 MW \\
\hline \hline $\begin{array}{c}\text { Special category and } \\
\text { NE states }\end{array}$ & INR 25,000/kW & INR 25 million (USD 500,000) \\
& (USD 500/kW) & for the first MW; INR 4 million \\
& & $\begin{array}{c}\text { (USD 80,000) for each } \\
\text { additional MW }\end{array}$ \\
Other states & INR 15 million (USD 300,000) \\
& for the first MW; INR 3.5 \\
& (USD 300/kW) & million (USD 70,000) for each \\
& & additional MW \\
\hline
\end{tabular}

In several states, various additional supporting policies are available for private small hydro projects, including wheeling and banking, buy-back of power, and allowances for third-party sale. Direct subsidies for different project costs are available. ${ }^{282}$

For 2009-2010, CERC has established preferential levelized tariffs for different states and plant capacities (see Table 5-5). Projects below $5 \mathrm{MW}$ often have higher capital and operating costs and cannot take advantage of economies of scale. Though projects in Himachal Pradesh, Uttarakhand, and the northeastern states have a higher capital cost, they also have higher capacity factors due to the hilly terrain and resource availability, so the

\footnotetext{
${ }^{279}$ MNRE. Annual Report 2009-10. http://mnre.gov.in/annualreport/2009-10EN/index.htm. Accessed July 2010. ${ }^{280}$ MNRE. Annual Report 2009-10. http://mnre.gov.in/annualreport/2009-10EN/index.htm. Accessed July 2010. ${ }^{281}$ MNRE. Annual Report 2009-10. http://mnre.gov.in/annualreport/2009-10EN/index.htm. Accessed July 2010. ${ }^{282}$ MNRE. "Small Hydro Power Programme." http://www.mnre.gov.in/prog-smallhydro.htm. Accessed October 2010 .
} 
tariffs offered in these states are less than those offered for projects in other states. ${ }^{283}$ The tariff period for small hydro of less than $5 \mathrm{MW}$ has been modified to run for 35 years in order to provide long-term certainty. The tariff period for small hydropower above $5 \mathrm{MW}$ is 13 years, which is the same as for all renewable energy other than solar power. ${ }^{284}$ Based on recommendations by CERC, 23 states have declared that they will create attractive investment possibilities for the private sector through incentive schemes. Ten states have already made concrete offers in this direction. Developers also have the option to negotiate special tariffs on a project basis.

Table 5-5. CERC-Small Hydro Preferential Tariffs for FY 2009-2010 285

\begin{tabular}{|ccc|}
\hline Category & $\begin{array}{c}\text { Levelized Tariff } \\
\text { INR (USD) per kWh }\end{array}$ & $\begin{array}{c}\text { Net-levelized Tariff after } \\
\text { Adjusting for Accelerated } \\
\text { Benefit }\end{array}$ \\
INR (USD) per kWh
\end{tabular}

In order to be eligible for governmental incentive schemes, a project developer must fulfill different standards of the IEC as well as the International Standards. These standards are: ${ }^{286}$

- For turbines and generators (rotating electrical machines): IEC 60034-1: 1983; IEC 61366-1: 1998; IEC 61116: 1992; IS 4722-2001; IS 12800 (part 3)-1991.

- Field study for hydraulic power of the turbines: IEC 60041-1991.

- Control system of the hydraulic turbines: IEC 60308.

- Transformers: IS 3156-1992, IS 2705-1992, IS 2026-1983.

- Inlet valves of power plants and systems: IS 7326-1902.

\subsection{Investment Flows and Industrial Trends}

Until the end of the 1990s, the Indian small hydropower market, similar to the entire power market, was dominated by public-sector companies. Most plants even today are operated by the various state power utilities with central government companies playing a smaller role. In

\footnotetext{
${ }^{283}$ CERC. "Regulations."

http://cercind.gov.in/Regulations/Final_SOR_RE_Tariff_Regulations to upload 7 oct_09.pdf. Accessed September 2010.

${ }^{284}$ CERC. "Regulations."

http://cercind.gov.in/Regulations/Final_SOR_RE_Tariff_Regulations_to_upload_7_oct_09.pdf. Accessed September 2010.

${ }^{285}$ CERC. "Tariff Order.” http://www.cercind.gov.in/2009/November09/284-2009 final 3rdDecember09.pdf. Accessed September 2010.

${ }^{286}$ MNRE. "Small Hydro Power Programme." http://mnre.gov.in/prog-smallhydro.htm. Accessed September 2010 .
} 
recent years, private companies have also started to get involved. Investor interest is increasing due to new incentive systems. As of December 2009, the private sector has accomplished 192 projects with a total capacity of $1,005 \mathrm{MW} .^{287}$ This corresponds to $39 \%$ of the total installed capacity. In addition, 296 private projects totaling approximately $936 \mathrm{MW}$ are in various stages of implementation. ${ }^{288}$ The State of Karnataka leads with 66 private projects holding a capacity of $521 \mathrm{MW} .{ }^{289}$

Most project developers and plant operators are not hydropower specialists but come from the broader energy and infrastructure sector. Examples are HEG Limited and Bharat Petroleum Corporation Limited.

India has a good network of local manufacturers and service providers who can provide complete systems as well as construction and spare parts such as turbines, regulators, and generators.

\subsection{Implication in Rural Electrification}

Small hydropower is well-suited for rural, remote, and hilly regions, such as the Himalayas, due to the high capacity factors of plants established in these areas.

MNRE has developed a special financial incentives package for on- and off-grid small hydropower in northeast India. As of March 2010, 151 projects, totaling 241.27 MW, have been implemented and another 53 projects, totaling 58.05 MW, were under execution. ${ }^{290}$

During financial year 2009-2010, three new projects totaling $10 \mathrm{MW}$ were approved in Arunachal Pradesh and two projects at $3 \mathrm{MW}$ have been approved for R\&M. The ministry has also approved 13 micro hydro projects and 20 watermills in Sikkim. ${ }^{291}$

Arunachal Pradesh Energy Development Agency is executing a program to electrify all border villages in the state through solar, hydro, and micro-hydro systems. This is under the Prime Minister's Special Package worth INR 2.75 billion (USD 55 million) over 3 years. Out of 1,483 villages, 603 will be covered through 62 small hydro projects, 334 through 137 micro-hydro projects, and the remaining 546 through solar PV. ${ }^{292}$

In 2002, Andhra Pradesh set up a governmental agency, Tribal Power Company, for implementing small hydro projects (1-3 MW each) in tribal areas, which are otherwise restricted for development. These projects should be developed in partnership with tribal women, and all profits from the projects are to go to the tribes. ${ }^{293}$

\footnotetext{
${ }^{287}$ MNRE. Annual Report 2009-10. p. 54. http://mnre.gov.in/annualreport/200910EN/Chapter\%206/chapter\%206 1.htm. Accessed July 2010.

${ }^{288}$ MNRE. Annual Report 2009-10. p. 54. http://mnre.gov.in/annualreport/200910EN/Chapter\%206/chapter\%206_1.htm. Accessed July 2010.

${ }^{289}$ MNRE. http://mnre.gov.in. Accessed July 2010.

${ }^{290}$ MNRE. "Renewable Energy in North Eastern States." p. 86. http://mnre.gov.in/annualreport/200910EN/Chapter\%209/chapter\%209 1.htm. Accessed July 2010.

${ }^{291}$ MNRE. "Renewable Energy in North Eastern States." p. 86. http://mnre.gov.in/annualreport/200910EN/Chapter\%209/chapter\%209 1.htm. Accessed July 2010.

${ }^{292}$ Ashkay Urja. "National Workshop on Village Energy Security Program.” Vol. 2, Issue 16, June 2009 ; p. 43. http://www.mnre.gov.in/akshayurja/june09-e.pdf. Accessed October 2010.

${ }^{293}$ TRIPCO. "Particulars of the Organization, Functions and Duties." http://www.aptribes.gov.in/html/tripco/1.pdf. Accessed October 2010.
} 


\subsection{Technology Development and Transfer}

Small hydropower has a capital cost of about INR 50-60 million (USD 1-1.2 million) per MW, which is slightly higher than wind, and a levelized energy cost of about INR 1.50-2.50 (USD 0.03-0.05) per $\mathrm{kWh}$, which is the lowest among renewable energy technologies in India. ${ }^{294}$

Small hydropower equipment has been undergoing steady improvement in efficiency and reliability. This is primarily because of a shift from mechanical to automated electronic control systems and grid integration. Further improvements include remote operating projects and utilization of automatic data collection systems to allow remote monitoring of system performance. The technological trend is to continue to improve reliability and reduce capital cost while increasing efficiency. Logistical and civil construction processes need to be redesigned to reduce installation time. Advancements can also be made in sediment management to reduce silting of equipment. ${ }^{295}$

\subsection{Local Case Studies}

The Indian industrial company BHEL is a key player in this sector with over $20 \%$ of the total installed capacity. ${ }^{296}$ BHEL has been involved in the design and manufacture of large hydropower equipment since 1966 (contributing 16,996 MW of capacity to India's total) and with modern renewable technologies since the $1980 \mathrm{~s} .{ }^{297}$ The company has been pioneering the smallest rated bulb and Pelton turbines as well as the highest speed 1,500 RPM Francis turbines. ${ }^{298}$

There are also a number of medium-sized companies in this sector such as Boving Fouress, Escher Wyss Flovel, Jyoti, Steel Industrials Kerala, Kirloskar Bros, HPP Energy, Flovel Mecamidi Energy, Prakruti Hydro Labs, Indusree, Ushvin Hydro System, DRG Jalshakti Eng., Gita Flow Pumps, Pentaflo Hydro Engineers, Everest Energy, Plus Power System, Standard Electronics Instruments Corporation, and Vinci Aqua Systems. Most offer equipment as well as turnkey solutions and maintenance services. Pentaflo Hydro Engineers is an example of a small hydropower manufacturer based in Delhi. The company manufactures Pelton, Francis, Butterfly Valve, Kaplan, Micro, and Cross Flow turbines for projects from $1 \mathrm{MW}$ to $5 \mathrm{MW} \cdot{ }^{299}$ Flovel Mecamidi Energy specializes in complete hydro solutions and has over 20 projects under implementation. The company employs 220 people and had a sales turnover of over INR 900 million (USD 18 million) for financial year 2009$20100^{300}$

\footnotetext{
${ }^{294}$ Government of India Planning Commission. "Integrated Energy Policy: Report of the Expert Committee." 2006; p. 90. http://planningcommission.nic.in/reports/genrep/rep intengy.pdf. Accessed July 2010.

${ }^{295}$ MNRE. http://www.mnre.gov.in/shp-rand.htm. Accessed September 2010. Alternate Hydro Energy Centre IIT; Roorkee; MNRE. "Standards/Manuals/Guidelines for Small Hydro Development." http://www.iitr.ac.in/PageUploads/files/1_12\%2520Guidelines\%2520for\%2520modernization\%2520and\%2520 renovation $\% 2520$ of $\% 2520$ SHP\%2520stations.pdf. Accessed September 2010.

${ }^{296}$ Awasthi, S.R. "Development of Renewable Energy Technologies in India, The Role of BHEL" http://www.indiaenvironmentportal.org.in/files/BHEL.pdf June 2009. Accessed October 2010.

${ }^{297}$ Awasthi, S.R. "Development of Renewable Energy Technologies in India, The Role of BHEL" http://www.indiaenvironmentportal.org.in/files/BHEL.pdf June 2009. Accessed October 2010.

${ }^{298}$ Awasthi, S.R. "Development of Renewable Energy Technologies in India, The Role of BHEL" http://www.indiaenvironmentportal.org.in/files/BHEL.pdf June 2009. Accessed October 2010.

${ }^{299}$ Pentaflo Hydro Engineers. http://www.pentaflo.com/about.html. Accessed October 2010.

${ }^{300}$ Flovel Mecamidi. http://www.flovel.in/About-Us.html. Accessed October 2010.
} 


\subsection{Success Stories from the International Community and Potential Opportunities for India}

China has made extensive use of small hydro in rural electrification programs, and this sector continues to grow with approximately $33 \mathrm{GW}$ of small-hydro plants (less than $10 \mathrm{MW}$ ) added in 2009. ${ }^{301}$ Several factors have contributed to the success of small hydro in China, including the low-interest loans provided by the Ministry of Water Resources, ${ }^{302}$ government subsidies for capital costs under the Chinese Township Electrification Program, and the effective mobilization of private capital. ${ }^{303}$

The Energy Management Centre in Kerala partnered with UNIDO to establish a regional center for small hydro. The aim of this center is to transfer practices from China's successful small hydro program to the region. ${ }^{304}$ The center conducts capacity building events, analysis and design of small-hydro plants, and outreach and coordination regionally and internationally. ${ }^{305}$

International small-hydro companies are not yet very active but are increasingly interested in the Indian market. For example, the project developer Epuron invests in small hydropower in Karnataka. Companies like Alstom, ABB, and Voith Hydro are offering components and engineering services in India. ${ }^{306}$

The Indian market for small hydropower offers good business opportunities to international companies. The market development has been very positive and constant, and the applicability and economic viability of small hydro technology in India has been proven adequately. In order to develop hydropower projects, foreign companies prefer to work with an Indian partner who has a good local network in the relevant region and can take the lead on the purchase of land and the approval processes.

\footnotetext{
${ }^{301}$ REN21. "Global Status Report 2010.” http://www.ren21.net/globalstatusreport/g2010.asp. Accessed October 2010 .

${ }^{302}$ NREL. "Renewable Energy Policy in China: Financial Incentives." http://www.nrel.gov/docs/fy04osti/36045.pdf. Accessed October 2010.

${ }^{303}$ Limin, H. "Financing Rural Renewable Energy: A Comparison Between China and India." Renew. Sustainable Energy Rev.; Vol. 13, 2009; pp. 1096-1103.

${ }^{304}$ UNIDO. http://www.unidorc.org/emc shp.htm. Accessed October 2010.

${ }^{305}$ UNIDO. http://www.unidorc.org/emc act.htm. Accessed July 2010.

${ }^{306}$ MNRE. "List of Equipment Manufacturers of Small Hydro Turbines." http://mnre.gov.in/manufacurerssht.htm Accessed October 2010.
} 


\section{Bioenergy}

\section{Chapter Overview}

Historically, traditional biomass has been a major source of household energy in India. Today, the total energy supply in India is composed of approximately $40 \%$ non-commercial energy sources such as wood and cow dung. ${ }^{307}$ Rural households in India predominantly use wood and cow dung as fuel for cooking and water heating due to lack of electricity. ${ }^{308}$ Modern biomass energy is derived from organic material and can be used in a variety of conversion processes to yield power, heat/steam, and fuel. In India, the use is focused on waste materials such as municipal, agricultural, or forest residues. Biomass is generally divided into three categories: biogas, solid biomass, and liquid biofuels.

Biogas has been mostly used for small, rural, and off-grid applications, and the majority of gasifiers in India are providing for individual households. About 4 million family-size biogas plants were installed in India and MNRE estimates that the annual biogas generation potential is about 17,340 million $\mathrm{m}^{3}$, which could support the installation of up to about 12 million family-size biogas plants. Another 70 projects with aggregated capacity of $91 \mathrm{MW}$ electricity equivalent were installed in India through larger scale biogas facilities use wastewater generated from beverage, meat processing, pulp and paper, food packaging, and other industrial sectors. Another 73 medium biogas plants with aggregated capacity of $461 \mathrm{~kW}$ have been installed under Distributed/Grid Power Generation Program of the Ministry. Existing incentives for encouraging biogas production include financial incentives for turnkey operations in rural areas, loans for developing biogas plants in agricultural priority areas, and automatic refinancing offered by the National Bank for Agriculture and Rural Development (NABARD).

Biomass resources in India are used for power generation through three general applications: grid-connected biomass power plants, off-grid distributed biomass power applications, and cogeneration via sugar mill and other industries. The amount of biomass resources in India is estimated about 565 million tonnes per year, including agricultural residues and forest residues. The surplus biomass resources (not used for animal feed, cooking, or other purposes) available for power generation annually is about 189 million tonnes, which could support roughly $25 \mathrm{GW}$ of installed capacity.

India's biofuel strategy is currently focused on using non-food feedstock for the production of biofuels, mainly sugar molasses and non-edible oils, and development and application of advanced conversion technologies are being explored for the near future. The commercial production of biodiesel is very limited, and what is produced is mostly sold for experimental projects and to the unorganized rural sector. The existing biodiesel producers in India are using non-edible oilseeds, non-edible oil waste, animal fat, and used cooking oil as feedstock.

\subsection{Biogas}

Biogas is obtained via an anaerobic process of digesting organic material such as animal waste, crop residues, and waste from industrial and domestic activities to produce the combustible gas methane. In India, most biogas plants primarily use cattle manure and

\footnotetext{
${ }^{307}$ European Energy Forum. "Energy Policy in India Dinner Debate." http://www.europeanenergyforum.eu/archives/european-energy-forum/energy-management-and-policy/energypolicy-in-india. Accessed September 2010.

${ }^{308}$ Karandikar, V.; Rana, A. "Future of Energy Options for India in an Independent World." Reliance Industries Ltd.; p. 6. http://www.worldenergy.org/documents/p001145.pdf. Accessed September 2010.
} 
operate at a household level to meet cooking and lighting needs in rural areas throughout the country. MNRE estimates that with the biogas generation potential, about 12 million familysize biogas plants could be supported. An additional 1,300 MW could be supported from biogas using industrial wastewater (primarily from distilleries and sugar and starch processing plants).

\subsubsection{Resource/Technological Potential}

Biogas can be combusted directly as a source of heat for cooking, used for space cooling and refrigeration, or used as fuel in gas lamps for lighting. It may also be used to fuel internal combustion engines for production of mechanical work or for electricity. The slurry produced after digestion can be used directly as a valuable fertilizer.

In India, most biogas plants operate at a household level to meet cooking and lighting needs in rural areas. MNRE reports that there are about 4 million family-size biogas plants installed in the country and estimates that the annual biogas generation potential (based on available cattle manure) is about 17,340 million $\mathrm{m}^{3}$, which could support the installation of up to about 12 million family-size biogas plants. In addition, there are larger plants servicing clusters of houses and whole villages. As of 2006, the total number of community-level biogas plants was 3,902, which is a small number compared to India's 600,000 villages. ${ }^{309}$ Given India's large population and high density (Figure 6-1) of cattle, cattle manure has become the primary feedstock for biogas generation at a domestic and community level. With about $28 \%$ of the world's total cattle population, India ranks first in the world.

\footnotetext{
${ }^{309}$ Ravindranath, N.H.; Balachandra, P. "Sustainable Bioenergy for India: Technical, Economic and Policy Analysis.” Energy J.; Iss. 34, 2009; pp. 1003-1013.
} 


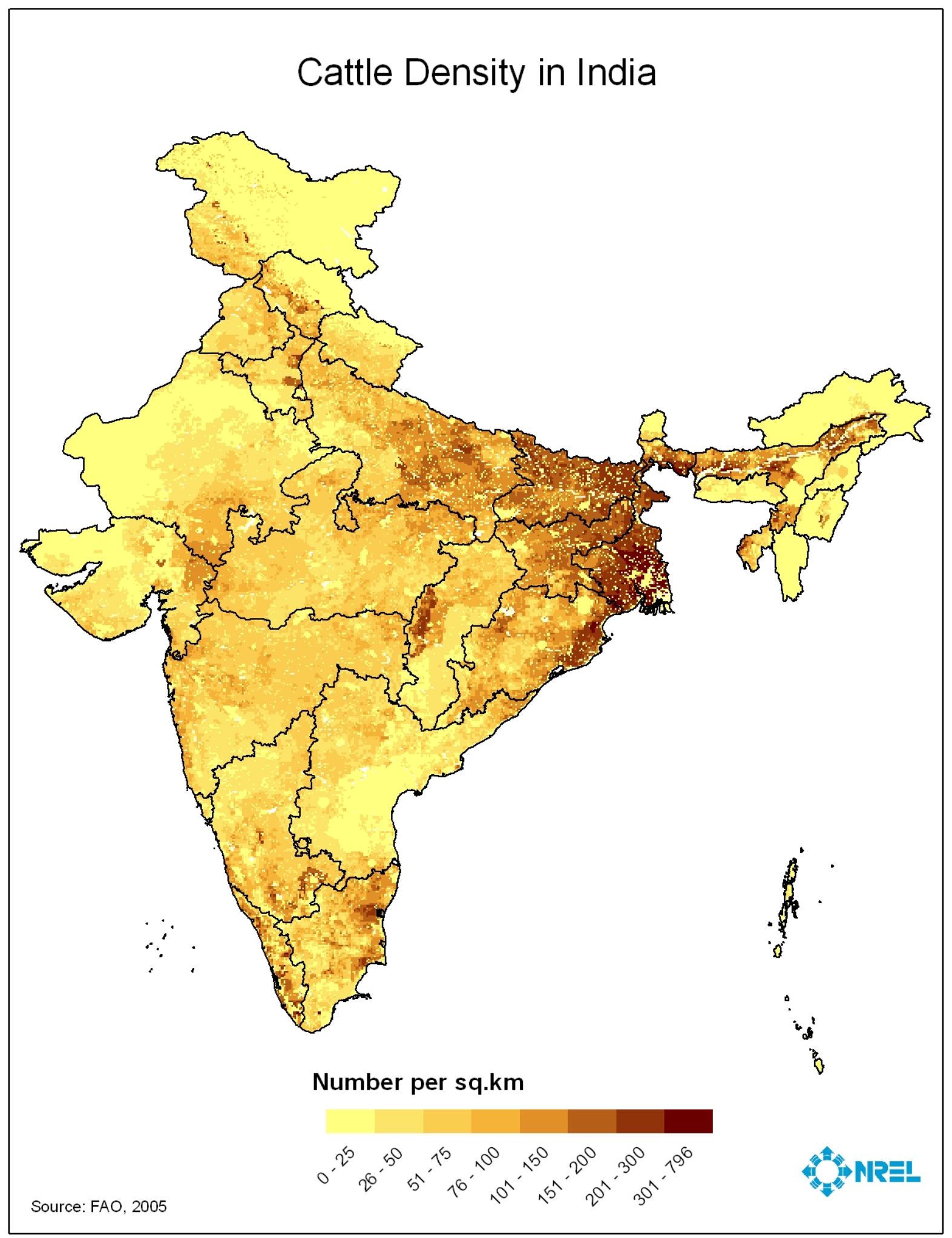

Figure 6-1. Cattle density in India

The larger-scale biogas facilities use wastewater generated from beverage, meat processing, pulp and paper, food packaging, and other industries to produce electricity. MNRE reports that 70 projects with an aggregate capacity of $91 \mathrm{MW}$ have been installed under the Energy 
Recovery from Urban and Industrial Waste programs of the Ministry. ${ }^{310}$ The estimated potential from industrial effluent is about $1.3 \mathrm{GW}$, and potential is expected to reach $2 \mathrm{GW}$ by $2017 .^{311}$ MNRE is exploring opportunities for installing anaerobic digesters at sewage treatment plants to generate biogas for electricity production. The agency estimates that the liquid organic waste generated every year by the urban population in India could support over $2.5 \mathrm{GW}$ of installed capacity.

Electricity is also produced by biogas plants installed under the Biogas Distributed/Grid Power Generation Program (BGPG) launched by MNRE in 2006. Under this program, the projects are developed at the village level by a community organization, institution, or private entrepreneurs, and the produced electricity is sold to individuals or communities or to the grid on mutually agreed terms. The unit capacity ranges from $3 \mathrm{~kW}$ to $250 \mathrm{~kW}$. MNRE reports that, currently, there are 73 projects installed with a total capacity of $461 \mathrm{~kW} .^{312}$

\subsubsection{Capacity Growth}

MNRE reports that 101,529 family-size biogas plants (1-6 $\mathrm{m}^{3}$ capacity) were installed in India during financial year 2008-2009. ${ }^{313}$ This resulted in an estimated savings of about 120,000 tonnes of fuel wood equivalent and generated about 3 million person-days of employment for skilled and unskilled workers in rural areas. Additionally, 51,732 family-size biogas plants were installed between April and December 2009 (out of the planned 150,000 family-size biogas plants for the entire financial year 2009-2010).

MNRE reported that 10 biogas projects using industrial waste, with a total capacity of approximately $10 \mathrm{MW}$, were completed during 2008-2009. These included 1.40 MW of installed capacity at a distillery in Tiruchirapally (Tamil Nadu), 3.66 MW using poultry litter in Dupalapudi (East Godavari District, Andhra Pradesh), $0.69 \mathrm{~kW}$ at a distillery in Ahmedhnagar (Maharashtra), 1.00 MW using starch waste in Gujarat, and six projects in the states of Maharashtra, Uttarakhand, Madhya Pradesh, Karnataka, and Tamil Nadu with a total capacity of 3.19 MW using liquid waste from the food industry and tanneries. Additionally, eight projects with an aggregate capacity of approximately $14 \mathrm{MW}$ were completed in 2009. These included five projects totalling approximately $12 \mathrm{MW}$ installed capacity at distilleries, two $1 \mathrm{MW}$ projects using waste from starch factories, and one small project generating biogas from yeast waste.

Under BGPG, 65 new projects with a total installed capacity of 0.353 MW were initiated in the states of Andhra Pradesh, Chhattisgarh, Kerala, Maharashtra, and Uttarakhand during 2008-2009. Approximately 14 additional projects were initiated during this time in Tamil Nadu and another 11 projects in Kerala. During 2009-2010, one new project was initiated in Haryana and several project proposals were received from the states of Andhra Pradesh, Goa, Maharashtra, Tamil Nadu, and by Khadi and Village Industries Commission.

\footnotetext{
${ }^{310}$ Maithani, P.C. MNRE. Personal communication. October 2010.

311 MNRE. “Annual Report 2009-10.” http://www.mnre.gov.in/annualreport/200910EN/Chapter\%205/chapter\%205 1.htm. Accessed October 2010.

312 Maithani, P.C. MNRE. Personal communication. October 2010.

${ }^{313}$ MNRE. “Annual Report 2009-10.” http://mnre.gov.in/annualreport/2009-10EN/index.htm. Accessed May 2010 .
} 


\subsubsection{Existing Policies, Measures, and Local Regulations}

Under the Eleventh Plan, the Government of India established a goal of deploying 2 million family-size biogas plants. ${ }^{314}$

Currently, incentives for biogas projects include: ${ }^{315}$

- Financial incentives for turnkey operations in rural areas.

- Loans for developing biogas plants in agricultural priority areas.

- Automatic refinancing offered by NABARD.

The National Biogas and Manure Management Program (NBMMP), implemented in 1981, continues to support the deployment of biogas plants utilizing manure and other organic wastes. ${ }^{316}$ The financial support ranges from INR 2,100 (USD 42) to INR 11,700 (USD 234) per plant. This program focuses on family-size installations to meet the cooking and energy needs of households and the manufacturing of fertilizers in rural areas. Under the NBMMP, 12 biogas training centers have been established throughout India to develop local technical capacity in this field.

The BGPG focuses mainly on the promotion of small capacity biogas-based power generation. In 2008, MNRE established a demonstration program, the Demonstration of Integrated Technology Package on Biogas Generation Purification and Bottling, to determine the feasibility of integrating "generation, purification/enhancement, bottling and piped distribution of biogas" at medium-sized facilities. ${ }^{317}$ Under the first phase of this program, MNRE provided financial support up to $50 \%$ of the project costs.

MNRE provides incentives for the recovery of energy from MSW and other urban waste streams under the Programme of Energy Recovery. ${ }^{318}$ In 2010, five MSW pilot projects are eligible to receive INR 20 million (USD 400,000) per MW installed, up to 20\% of the project costs, or INR 100 million (USD 2 million) total, whichever is lower. MNRE also provides $40 \%$ of the total project costs with a maximum incentive of INR 20 million (USD 400,000) per MW for the generation of electricity from biogas at sewage treatment plants. For power generation from biomethanation-based projects, MNRE will provide up to $30 \%$ of the project costs with a maximum incentive of INR 30 million (USD 600,000) per MW. Both private and public sector projects are eligible for these waste-to-energy incentives.

For the industrial sector, MNRE provides support for the recovery of energy from wastes. ${ }^{319}$ Under the Programme on Energy from Industrial Wastes, MNRE provides financial assistance for resource assessment, $R \& D$, technology improvements, performance evaluation,

\footnotetext{
314 Government of India Planning Commission. "Eleventh Five Year Plan 2007-12: Agriculture, Rural Development, Industry, Services, and Physical Infrastructure.” http://planningcommission.nic.in/plans/planrel/fiveyr/11th/11_v3/11th_vol3.pdf. Accessed April 2010. ${ }^{315}$ New Energy India. "RE Policy Overview." http://www.newenergyindia.org/Policy\%20Page.htm. Accessed May 2010.

${ }^{316}$ MNRE. Annual Report 2009-10. http://mnre.gov.in/annualreport/2009-10EN/index.htm. Accessed May 2010 .

${ }^{317}$ MNRE. Annual Report 2009-10. http://mnre.gov.in/annualreport/2009-10EN/index.htm. Accessed May 2010.

${ }^{318}$ MNRE. Annual Report 2009-10. http://mnre.gov.in/annualreport/2009-10EN/index.htm. Accessed May 2010.

${ }^{319}$ MNRE. Annual Report 2009-10. http://mnre.gov.in/annualreport/2009-10EN/index.htm. Accessed May 2010 .
} 
and other associated components of waste-to-energy projects. Industrial sector waste-toenergy projects are eligible to receive incentives between INR 5-10 million (USD 100,000 $200,000)$ per MW. These incentives are available for both private and public sector projects.

\subsubsection{Local Policies}

The State of Haryana announced a program promoting the installation of 50,000 family-size biogas plants. The program is designed to take advantage of CDM funding by having a single financial institution undertake the project as a whole instead of focusing on individual project installations by separate entities. ${ }^{320}$

\subsubsection{Investment Flows and Industrial Trends}

The demand for and number of small technical and thermal gasification plants is increasing in India. The wide ranges of manufacturers in this market are steadily improving their technology and products, which has lead to an establishment of Indian companies in the global market. ${ }^{321}$ Thus, foreign companies face strong competition from already established Indian companies in the Indian market who have knowledge of local conditions and requirements.

For larger scale projects on the MW-scale level, biogas plants have not yet been widely commercialized. Given the significant potential for biogas from various sources of agricultural or industrial waste, companies able to develop reproducible and sustainable business models for larger projects have a great market opportunity in India. A further step of value creation can be added by upgrading biogas to natural gas equivalent and feeding it into the grid. This technology is not applied yet in India.

Some international companies are now venturing into this field. In the scope of a publicprivate partnership, EnviTec, a German biogas specialist, and its Indian partner MPPL, with the support of GTZ, are planning a pilot project in Punjab. The project is to have a capacity of $25 \mathrm{MW}$, later expanding to $750 \mathrm{MW} .^{322}$

\subsubsection{Technology Development and Transfer}

During 2008-2009, MNRE established a new initiative to demonstrate an integrated technology for biogas plants at a medium scale $\left(200-1,000 \mathrm{~m}^{3} /\right.$ day $)$. This technology integrates biogas generation, purification/enrichment, bottling, and piped distribution. During 2009-2010, eight integrated biogas plants at a medium scale, with an aggregate capacity of $5,700 \mathrm{~m}^{3} /$ day, were initiated in the states of Bihar, Chhattisgarh, Gujarat, Haryana, Karnataka, Maharashtra, and Punjab. ${ }^{323}$

\subsubsection{Local Case Studies}

There are some interesting cases of companies who develop biogas solutions on a mass scale. One example is the Indian company SKG Sangha, who develops small biogas plants for domestic use in Karnataka. Animal and household wastes are used as feedstock, thereby replacing firewood with sustainable and less-polluting sources and improving waste disposal.

\footnotetext{
${ }^{320}$ Financial Express. (2010). "Haryana Looks at Biogas Plants to Boost Green Energy Use." 8 February 2010. http://www.financialexpress.com/news/haryana-looks-at-biogas-plants-to-boost-green-energy-use/576777/1. Accessed May 2010.

321 “Länderprofil Indien.” Berlin: Deutsche Energie-Agentur GmbH, 2007 (update February 2010).

${ }^{322}$ Developpp.de. http://www.developpp.de. Accessed July 16, 2010.

${ }^{323}$ MNRE. Annual Report 2009-10. http://mnre.gov.in/annualreport/2009-10EN/index.htm. Accessed May 2010 .
} 
By 2009 , over 80,000 plants had been installed, each saving around 4 tons of $\mathrm{CO}_{2}$ per year. The plants were built and maintained by 2,000 employees. $^{324}$

Another successful case study comes from Kerala, where 16,000 plants were installed by the Indian company BIOTECH by 2009 . Home, market, and municipal waste are used as feedstock, and the plants vary in size. The installation costs can be partly reduced through government subsidies, and an average family is able to finance a plant within 3 years. ${ }^{325}$

\subsection{Solid Biomass}

Solid biomass includes agricultural and forest residues as well as organic household and industrial wastes for direct combustion or gasification to provide electricity or combined electricity and heat (cogeneration). MNRE estimates that the surplus biomass resources potentially available for power generation could support roughly $25 \mathrm{GW}$ of installed capacity. ${ }^{326}$ Cogeneration plants are mainly found in the sugar industry where the heat can be used for the production process and the power surplus is typically sold to the grid. MNRE estimates that there is a potential of about $15 \mathrm{GW}$ using cogeneration in various industries including sugar mills, breweries, textile mills, distilleries, fertilizer plants, pulp and paper mills, and rice mills.

\subsubsection{Resource/Technological Potential}

Biomass resources in India are used for power generation in three general applications:

- Grid-connected biomass power plants (using combustion and gasification conversion technologies).

- Off-grid/distributed biomass power applications (using primarily gasification conversion technology).

- Cogeneration (simultaneous production of both heat energy and electricity from one energy source).

○ Bagasse cogeneration in sugar mills.

○ Non-bagasse cogeneration in other industries.

\subsubsection{Power Generation}

MNRE estimates the amount of biomass resources in India at about 565 million tonnes per year, including agricultural residues (resulting from crop harvesting and processing) and forest residues (resulting from logging and wood processing). The agricultural residues, which provide most of the biomass resources in the country, include rice husk, rice straw, bagasse, sugar cane tops and leaves, groundnut shells, cotton stalks, and mustard stalks. Some of the agricultural and forest residues are already in use as animal feed and fuel for domestic cooking, among other purposes. MNRE estimates that the amount of surplus biomass resources available for power generation annually is about 189 million tonnes, which could

\footnotetext{
${ }^{324}$ Ashden Awards. "Clean Cooking and Income Generation from Biogas Plants in Karnataka.” http://www.ashdenawards.org/files/reports/SKG_Sangha_2007_Technical_report.pdf. Accessed July 2010.

${ }^{325}$ Ashden Awards. "Management of Domestic and Municipal Waste at Source Produces Biogas for Cooking and Electricity Generation."

http://www.ashdenawards.org/files/reports/Biotech India 2007 Technical report .pdf. Accessed July 2010.

${ }^{326}$ MNRE. "Biomass Resource Atlas of India." v2.0; 2009. Biomass data by state 2002-04, http://lab.cgpl.iisc.ernet.in/Atlas/Tables/Tables.aspx. Accessed October 2010.
} 
support roughly $25 \mathrm{GW}$ of installed capacity. ${ }^{327}$ As illustrated in Figure 6-2, states with the highest potential include Maharashtra, Madhya Pradesh, Punjab, Gujarat, and Uttar Pradesh. Total biomass power installed capacity in India is about $829 \mathrm{MW}$.

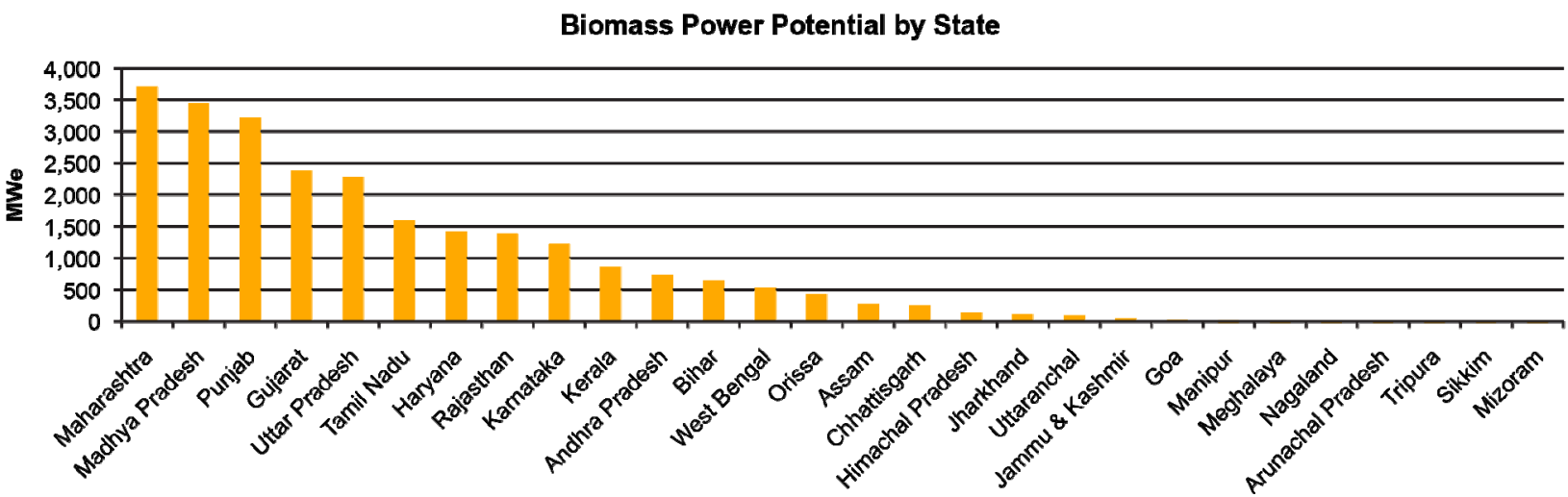

Source: MNRE. Biomass Resource Atlas of India v2.0; includes agricultural and forest residues

\section{Figure 6-2. Biomass potential by state}

\subsubsection{Cogeneration}

Cogeneration plants provide both heat energy, used in the mill, and electricity, which is typically sold to the grid. MNRE estimates that about $15 \mathrm{GW}$ of electricity generating capacity could be achieved through adding cogeneration capabilities in various industries including sugar mills, breweries, textile mills, distilleries, fertilizer plants, pulp and paper mills, and rice mills. Alternatively, gasifier systems that convert biomass resources into a combustible gas for the generation of electricity and heat could be installed at these plants to meet their captive energy requirements.

India is the world's second largest sugar producer with production companies concentrated in the sugarcane-growing states of Uttar Pradesh, Maharashtra, Gujarat, Tamil Nadu, Karnataka, and Andhra Pradesh. Uttar Pradesh accounts for 31\% of the total sugar production in the nation and Maharashtra's contribution is close to $28 \%$. The Indian government encourages sugar mills to invest in cogeneration plants using bagasse, the fibrous residue remaining after sugarcane stalks are crushed to extract their juice. MNRE reports that there are about 550 sugar mills in the country with a potential for $5 \mathrm{GW}$ installed capacity.

\subsubsection{Capacity Growth}

In 2008, the grid-connected capacity additions for biomass power and bagasse cogeneration were $97 \mathrm{MW}$ and $248 \mathrm{MW}$, respectively. ${ }^{328}$ Between April and December 2009, biomass power and bagasse cogeneration contributed $384 \mathrm{MW}$ of capacity additions bringing the total biomass power and cogeneration capacity to $2,136 \mathrm{MW} .{ }^{329}$ Biomass power projects contributed $125 \mathrm{MW}$ and bagasse cogeneration contributed $259 \mathrm{MW}$ during this period. The total installed grid-connected biomass power and bagasse cogeneration capacity was $2,322 \mathrm{MW}$ at the end of June $2010 .^{330}$

\footnotetext{
${ }^{327}$ MNRE. "Biomass Resource Atlas of India.” v2.0; 2009. Biomass data by state 2002-04, http://lab.cgpl.iisc.ernet.in/Atlas/Tables/Tables.aspx. Accessed October 2010.

${ }^{328}$ MNRE. Annual Report 2008-2009. http://www.mnre.gov.in/annualreport/2008-09EN/power-forrenewables.htm. Accessed October 2010.

${ }^{329}$ MNRE. Annual Report 2009-2010. http://www.mnre.gov.in/annualreport/200910EN/Chapter\%206/chapter\%206 1.htm. Accessed October 2010.

${ }^{330}$ MNRE. "Achievements." http://mnre.gov.in/achievements.htm. Accessed October 2010.
} 
MNRE reports that in the last 4 years, 63 non-bagasse cogeneration and 153 biomass gasifiers were brought online with total capacity of $211 \mathrm{MW}$ and $45 \mathrm{MWe}$, respectively, to provide power to industrial facilities. ${ }^{331}$ The cumulative installed capacity as of June 30 , 2010, was $238 \mathrm{MW}$ of biomass power and non-bagasse cogeneration and $125 \mathrm{MW}$ of biomass gasifiers. ${ }^{332}$

\subsubsection{Existing Policies, Measures, and Local Regulations}

During the Eleventh Plan, the central government plans to add 2,100 MW of grid-connected biopower, representing an increase of about $37 \%$ in total capacity installed compared to 2007.333

Incentives for biomass power projects include capital subsidies, tax benefits, and preferential tariffs.

\subsubsection{Tariff for Electricity Generated from Biomass}

For 2009-2010, CERC has established a levelized preferential tariff for biomass energy projects ranging from INR $3.93 / \mathrm{kWh}$ (USD $0.079 / \mathrm{kWh}$ ) to INR $5.52 / \mathrm{kWh}$ (USD $0.11 / \mathrm{kWh}$ ). ${ }^{334}$ The levelized tariff decreases to INR 3.35 (USD 0.064 ) to INR $4.62 / \mathrm{kWh}$ (USD $0.092 / \mathrm{kWh}$ ) in 2010-2011 (including available depreciation benefits, the net levelized tariff is INR 3.16 [USD 0.063] to INR 4.43/kWh [USD 0.089/kWh]).

Biomass projects may also qualify for $80 \%$ depreciation on specific equipment such as fluidized bed boilers and high efficiency boilers, a 10-year income tax holiday, and central excise duty exemptions. ${ }^{335}$

\subsubsection{Biomass Energy and Cogeneration Incentives}

Under the MNRE Biomass Energy and Cogeneration in Industries Programme, projects that utilize currently untapped resources to provide captive thermal energy and electricity can receive INR 200,000 (USD 4,000) to INR 1.5 million (USD 30,000) per $100 \mathrm{~kW}$ project for biomass gasifier systems and up to INR 2 million (USD 40,000) per MW for non-bagasse biomass cogeneration projects. The energy captured in these projects must be used onsite. Furthermore, financial incentives such as "accelerated depreciation, concessional custom duty, excise duty exemption, tax exemption, income tax exemption on projects for power generation for 10 years... are available to biomass power projects.",336

\footnotetext{
${ }^{331}$ MNRE. Annual Report 2009-2010. http://www.mnre.gov.in/annualreport/200910EN/Chapter $\% 205 /$ chapter $\% 205$ 1.htm. Accessed October 2010.

${ }_{332}$ MNRE. "Achievements." http://mnre.gov.in/achievements.htm. Accessed October 2010.

333 Government of India Planning Commission. "Eleventh Five Year Plan 2007-12: Agriculture, Rural Development, Industry, Services, and Physical Infrastructure."

http://planningcommission.nic.in/plans/planrel/fiveyr/11th/11_v3/11th_vol3.pdf. Accessed April 2010.

${ }^{334}$ Shah, S.R. "Feed-in Tariff and Renewable Purchase Obligation for Distribution Companies." Presentation to the Associated Chambers of Commerce and Industry of India at the Conference on Mainstreaming Green Energy - Wind, Biomass \& Solar on April 29, 2010 in Chennai. http://www.assocham.org/events/recent/showevent.php?id=426. Accessed August 2010.

${ }^{335}$ IREDA. "Incentives Available in the Sector (Biomass Power Generation)." http://www.ireda.gov.in/homepage1.asp?parent_category=2\&sub category=22\&category=27. Accessed May 2010.

${ }^{336}$ MNRE. Annual Report 2009-10. http://mnre.gov.in/annualreport/2009-10EN/index.htm. Accessed May 2010
} 


\subsubsection{Local Policies}

Local support for biomass power generation varies by state. ${ }^{337}$ Preferential tariffs for biomass projects are available in several states including Andhra Pradesh, Haryana, Madhya Pradesh, Maharashtra, Punjab, Rajasthan, Tamil Nadu, Bihar, Karnataka, West Bengal, Chhattisgarh, Gujarat, Uttarakhand, Kerala, and Uttar Pradesh ranging from INR 3.35/kWh (USD $0.067 / \mathrm{kWh}$ ) in Madhya Pradesh to INR 4.62/kWh (USD 0.092/kWh) in Haryana. ${ }^{338}$ Some states provide an exemption from the general sales tax, and some provide capital subsidies up to INR 2.5 million (USD 50,000) per MW. ${ }^{339}$

\subsubsection{Investment Flows and Industrial Trends}

According to MNRE, combustion of biomass and cogeneration has been used in the sugar industry for over 20 years, mainly for waste disposal. Since the primary aim was not to produce energy, the efficiency of these plants is low. However, the possibility to generate an additional benefit through feeding the energy surplus in the grid leads to new dynamics and new opportunities. Large companies like Triveni or Simbhaoli Sugars are changing from being solely sugar producers to also providers of energy technology and power.

Companies from other industries are realizing the business opportunities in biomass for largescale generation of electricity as well. A2Z Maintenance \& Engineering Services, an Indian EPC company, is planning to set up a $500 \mathrm{MW}$ power plant that uses municipal waste. ${ }^{340}$

As in the case of biogas, a proven market-entry strategy for foreign companies is in partnerships with local companies. The U.S.-based Indus Terra, for example, cooperates with Indian Emergent Ventures in the form of a special purpose vehicle: Green Indus Bio Energy Private Limited. The partnership is implementing a power project with a capacity of $5.6 \mathrm{MW}$, which will use poultry waste to generate electricity for the state power grid and slurry for fertilizer. A cluster of 150 poultry farms in Haryana, which can sell their waste to the plant, supports the initiative. Technology used will be designed in the UK, but the machines will be assembled in India. ${ }^{341}$

\subsubsection{Local Case Studies}

To tackle the problem of power cuts in Bihar, the local energy company, Saran Renewable Energy, has built a power plant that runs on gasified biomass from a local type of bush that farmers can easily and profitably grow. The generator connects to transmission lines to supply small businesses with electricity, hence providing energy security. The prices for users

\footnotetext{
${ }^{337}$ New Energy India. "RE Policy Overview.” http://www.newenergyindia.org/Policy\%20Page.htm. Accessed May 2010.

338 Naik, S.Y.; Yadav, S.S. "Renewable Energy Policy and Regulation Focusing on RPS." Presentation to the Associated Chambers of Commerce and Industry of India at the Conference on Mainstreaming Green Energy Wind, Biomass \& Solar on Apr. 29, 2010, in Chennai. http://www.assocham.org/events/recent/showevent.php?id=426. Accessed August 2010.

${ }^{339}$ IREDA. "Incentives Available in the Sector (Biomass Power Generation)." http://www.ireda.in/homepage1.asp?parent_category=2\&sub_category=27\&category=91. Accessed May 2010. ${ }^{340}$ Jayakumar, K.B. “A2Z Plans 500-MW Power Plant from Municipal Waste.” Business Standard June 6, 2010. http://www.business-standard.com/india/news/a2z-plans-500-mw-power-plantmunicipalwaste/09/23/397203/. Accessed July 2010.

${ }^{341}$ Gera, K.A. “And Now, Power Generation from Poultry Litter!” Business Standard June 8, 2010. http://www.business-standard.com/india/news/and-now-power-generationpoultry-litter/397347/. Accessed July 2010.
} 
are higher than the electricity from the grid, but the costs are still much less then for generating power by using diesel. ${ }^{342}$

Nishant Bioenergy developed a combined stove fuelled by crop waste and used in schools to cook meals for pupils. Local farmers that produce the waste sell it to local plants that compress it into briquettes for fuel use. Farmers are able to increase their income by an estimated $10 \%$, and the schools save on fuel costs. Nishant provides credit for the purchase of the stove, installs the stove, provides a 3-day training, and offers an annual maintenance contract. $^{343}$

Winrock International India started a remote village electrification initiative, which aims to promote alternative bioenergy in Chattisgarh. It uses Jatropha oil and is designed to be a replicable model for helping communities to be energy independent. Implemented in 2007, the initiative has served 107 households, or 553 people, with 3 hours per day of electricity generated for each household and 3.5 hours for streetlights. ${ }^{344}$

\subsection{Liquid Biofuels}

Liquid biofuels, namely ethanol and biodiesel, are used to substitute petroleum-derived transportation fuels. India's biofuel strategy is focused on using non-food sources for the production of biofuels: sugar molasses and non-edible oilseeds as well as second generation biofuels in the near future. Advanced conversion technologies for ethanol are under development, which will allow it to be made from forest and agricultural residues. Using onethird of the surplus, biomass could yield about 19 billion liters of ethanol, which could displace the country's entire gasoline consumption once techno-economically viable. Advanced feedstock for biodiesel production includes microalgae, which is currently under research and has a very promising potential in India - it can provide double the yield of the highest producing crop (oil palm) per land unit.

\subsubsection{Resource/Technological Potential}

\subsubsection{Ethanol}

In India, ethanol is produced by the fermentation of molasses, a by-product of the sugar industry. There are about 320 distilleries producing ethanol for industrial, beverage, and other purposes with a total production capacity of about 3.5 billion liters per year. More than 115 distilleries have modified their facilities to produce fuel grade ethanol with a total capacity of 1.5 billion liters per year. ${ }^{345}$ This production capacity is sufficient to meet the estimated ethanol demand of 800 million liters for a $5 \%$ blend with gasoline. ${ }^{346}$ However, for a $10 \%$ blend, the fuel grade ethanol production capacity from molasses needs to be expanded or the industry could consider direct production of ethanol from sugarcane juice, which offers

\footnotetext{
${ }^{342}$ Ashden Awards. "Replacing Diesel Generators with Biomass Gasification Systems." http://www.ashdenawards.org/files/reports/Saran_case_study 2009 final map.pdf. Accessed July 2010.

${ }^{343}$ Ashden Awards. "School Cookstoves Running on Crop Waste in North India." http://www.ashdenawards.org/files/reports/Nishant\%202005\%20Technical\%20report.pdf. Accessed July 2010. 344 "India Jatropha Electrification Initiative of Winrock International India." Good Practice Assessment Form. http://www.compete-bioafrica.net/bestpractice/COMPETE-032448-GoodPractice-CaseStudy1-India.pdf. Accessed July 2010.

${ }^{345}$ United States Department of Agriculture-Foreign Agricultural Service, Global Agricultural Information Network. "India Biofuels Annual 2009. http://gain.fas.usda.gov/Recent\%20GAIN\%20Publications/General\%20Report New\%20Delhi_India_6-122009.pdf. Accessed August 2010.

346 Jog, S. "Ethanol Price Fixed at Rs 27 Per Litre for Blended Fuel." Business Standard. April 8, 2010. http://www.business-standard.com/india/news/ethanol-price-fixed-at-rs-27-per-litre-for-blended-fuel/391159/. Accessed August 2010.
} 
higher productivity but will require additional investments for technological modifications. ${ }^{347}$ The direct production of ethanol from sugarcane juice requires an increase in feedstock production, which in India means developing higher yields per land unit rather than an increase in area planted with sugarcane because this crop is very water intensive and the country's irrigation water supplies are increasingly limited. ${ }^{348}$

Efforts to produce ethanol from other feedstock such as sweet sorghum, sugar beet, and sweet potatoes are at an experimental stage in India. ${ }^{349}$ Additionally, various public and private institutions in India are conducting research in the area of cellulosic ethanol, which uses feedstock such as agricultural and forest residues. As mentioned previously, India has a large amount of this biomass material and is therefore a promising potential for the production of cellulosic ethanol. Using one-third of the 189 million tonnes surplus of biomass could yield approximately 19 billion liters of ethanol (assuming one tonne of lignocellulosic biomass $=$ 300 liters of ethanol), which could displace the country's entire gasoline consumption (approximately 14 billion liters in 2008-2009). ${ }^{350}$

\subsubsection{Biodiesel}

India's commercial production of biodiesel is very small, and what is produced is mostly sold for experimental projects and to the unorganized rural sector. Although India's biodiesel processing capacity is currently estimated at 200,000 tonnes per year, the majority of biodiesel units are not operational during most of the year. The existing biodiesel producers in India are using non-edible oilseeds, non-edible oil waste, animal fat, and used cooking oil as feedstock. ${ }^{351}$

Biodiesel production efforts in India are focused on using non-edible oils since the demand for edible oils exceeds the domestic supply. It is estimated that the potential availability of non-edible oils in India amounts to about 1 million tonnes per year. The most abundant resources are sal oil (180,000 tonnes), mahua oil (180,000 tonnes), neem oil (100,000 tonnes), and Karanja oil (55,000 tonnes). However, based on extensive research carried out by various institutions in the country, the government identified Jatropha Curcas oilseed as the major feedstock for biodiesel in India. ${ }^{352}$

Since early 2001, the Ministry of Rural Development and several state governments have carried out programs to encourage large-scale planting of Jatropha on wastelands. States with the largest potential include Madhya Pradesh/Chhattisgarh, Rajasthan, Maharashtra, Andhra Pradesh, and Gujarat (Figure 6-3). The Indian government's Planning Commission set an

\footnotetext{
347 Gonsalves, J. “An Assessment of the Biofuels Industry in India.” United Nations Conference on Trade and Development, October 18, 2006, Geneva.

${ }^{348}$ United States Department of Agriculture-Foreign Agricultural Service, Global Agricultural Information Network. "India Biofuels Annual 2009.

http://gain.fas.usda.gov/Recent\%20GAIN\%20Publications/General\%20Report_New\%20Delhi_India 6-122009.pdf. Accessed August 2010.

${ }^{349}$ Gonsalves, J. "An Assessment of the Biofuels Industry in India." United Nations Conference on Trade and Development, October 18, 2006, Geneva.

${ }^{350}$ MPNG. "Basic Statistics on Indian Petroleum and Natural Gas 2008-09." September 2009, New Delhi, India. www.petroleum.nic.in/petstat.pdf. Accessed October 2010.

${ }^{351}$ United States Department of Agriculture-Foreign Agricultural Service, Global Agricultural Information Network. "India Biofuels Annual 2009.

http://gain.fas.usda.gov/Recent\%20GAIN\%20Publications/General\%20Report_New\%20Delhi_India 6-122009.pdf. Accessed August 2010.

${ }^{352}$ Gonsalves, J. "An Assessment of the Biofuels Industry in India." United Nations Conference on Trade and Development, 18 October 2006, Geneva.
} 
ambitious target of 11 million ha of Jatropha to be planted by 2012 in order to generate sufficient biodiesel to blend at $20 \%$ with petro-diesel. However, the total Jatropha plantation area in the country is currently estimated at approximately 450,000 ha, of which about $60 \%-$ $70 \%$ are new plantations (1-3 years old) and not yet into full production. The new Jatropha plantations are expected to come into maturity in the next 3-4 years. ${ }^{353}$

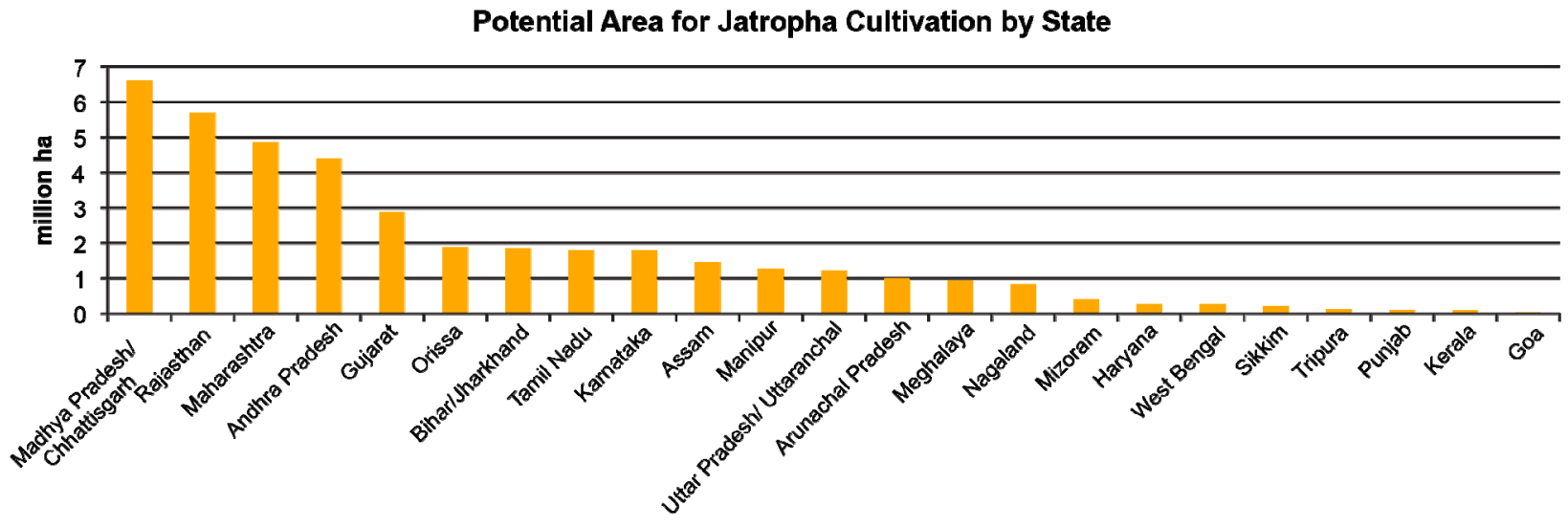

Figure 6-3. Potential area for Jatropha cultivation by state ${ }^{354}$

There is no commercial production of biodiesel from other resources such as microalgae, another promising feedstock, except for some experimental trials by research organizations.

\subsubsection{Capacity Growth}

\subsubsection{Ethanol}

The ethanol supply during 2008-2009 was severely impacted by the short supply of sugar molasses and continued strong demand for alcohol from other competing industries.

Consequently, the ethanol available for blending with petrol was about 100 million liters, considerably short of the 600 million liter target. This trend has continued through 2010, and the supply of ethanol for fuel was even lower at 50 million liters. ${ }^{355}$

\subsubsection{Biodiesel}

According to the Biodiesel Association of India, biodiesel production in the country during 2009-2010 was approximately 80,000 tonnes, sold entirely to commercial establishments using diesel generators.

\subsubsection{Existing Policies, Measures, and Local Regulations}

In 2003, India's Ministry of Petroleum and Natural Gas (MPNG) mandated 5\% ethanol blending with petrol in nine states and four union territories under Phase 1 of the ethanol

\footnotetext{
${ }^{353}$ United States Department of Agriculture-Foreign Agricultural Service, Global Agricultural Information Network. "India Biofuels Annual 2009."

http://gain.fas.usda.gov/Recent\%20GAIN\%20Publications/General\%20Report_New\%20Delhi_India_6-122009.pdf. Accessed August 2010.

${ }^{354}$ Punia, M.S. "Current Status of R\&D on Jatropha for Sustainable Biofuels Production in India." Ministry of Agriculture. USDA Global Conference on Agricultural Biofuels, Minneapolis, MN, 20-22 August 2007.

${ }^{355}$ United States Department of Agriculture-Foreign Agricultural Service, Global Agricultural Information Network. "India Biofuels Annual 2009." http://gain.fas.usda.gov/Recent\%20GAIN\%20Publications/General\%20Report_New\%20Delhi_India_6-122009.pdf. Accessed August 2010.
} 
blended petrol (EBP) program. ${ }^{356}$ Under Phase 2, this mandate was expanded to include 20 states and eight union territories in 2006. Due to supply shortages and extended negotiations between ethanol suppliers and state governments over state taxes and other fees, ethanol costs were too high to be commercially viable. As only domestically produced ethanol qualifies for the EBP program, and there continues to be a shortage of ethanol in India, the government has postponed implementation of Phase 3, which would raise the blended ethanol requirement to $10 \%$ in the participating states and require the remaining states to have at least a $5 \%$ ethanol blend ratio. The central government does not currently provide any direct financial or tax incentives for the production of ethanol but does offer subsidized loans for some sugar mills to set up ethanol production systems. The government does fund ethanol R\&D programs.

The Eleventh Plan set a goal to achieve at least a 5\% blend of biofuels for petrol by the middle of the plan period and to potentially increase the blend to $10 \%$ by the end of the Eleventh Plan. ${ }^{357}$ The plan also suggested that a 5\% blend of biodiesel might be possible by the end of the Eleventh Plan depending on availability. Proposed funding for biofuels R\&D from the National Energy Fund is INR 2 billion (USD 40 million). The Planning Commission established the goal for 11.2-13.4 million ha to be cultivated with Jatropha to generate sufficient biodiesel to achieve a $20 \%$ blend with petro-diesel. ${ }^{358}$ The government's initial demonstration phase brought 400,000 ha under production, and the plan is for production to be expanded in the coming years to meet the target by 2012. The MPNG established a program with 20 diesel procurement centers to purchase enough biodiesel to attain a 5\% blend ratio with high-speed diesel. However, the high cost to produce biodiesel has resulted in no biodiesel sales at these centers. Like for ethanol, the central government does not provide direct financial incentives for biodiesel production. However, biodiesel is exempted from the central excise tax and some state governments provide similar exemptions. Further, the central government and multiple state governments provide financial incentives to promote the cultivation of Jatropha and other non-edible oilseeds that may be used to produce biodiesel.

MNRE announced a National Policy on Biofuels in December 2009, which details targets, strategies and approaches, incentive levels, and policies for promoting the development and use of biofuels. $^{359,360}$

- Target $20 \%$ blending of biofuels with petrol and diesel by 2017 .

- Promote domestic biofuel production.

- Limit cultivation of biofuels to wastelands.

- Establish minimum support prices and minimum purchase prices for biofuels.

\footnotetext{
${ }^{356}$ Singh, S. "India-Biofuels Annual.” United States Department of Agriculture's Foreign Agricultural Service. GAIN Report No. IN9080; 2009.

${ }^{357}$ Government of India Planning Commission. "Eleventh Five Year Plan 2007-2012: Agriculture, Rural Development, Industry, Services, and Physical Infrastructure." http://planningcommission.nic.in/plans/planrel/fiveyr/11th/11_v3/11th_vol3.pdf. Accessed April 2010. 358 Singh, S. “India - Biofuels Annual.” United States Department of Agriculture's Foreign Agricultural Service. GAIN Report No. IN9080; 2009.

${ }^{359}$ MNRE. "National Policy on Biofuels." http://www.mnre.gov.in/policy/biofuel-policy.pdf. Accessed September 2010.

${ }^{360}$ Singh, S. "India-Biofuels Annual.” United States Department of Agriculture's Foreign Agricultural Service. GAIN Report No. IN9080; 2009.
} 
- Establish a National Biofuel Coordination Committee and a Biofuel Steering Committee to provide high-level coordination and policy guidance on the topic of biofuels and to oversee implementation of the program.

To support the national mission on Jatropha biodiesel, many states have announced extensive Jatropha cultivation programs such as Andhra Pradesh, Rajasthan, Maharashtra, Gujarat, Tamil Nadu, Chhattisgarh, and Haryana. ${ }^{361}$

\subsubsection{Investment Flows and Industrial Trends}

More than 20 companies are producing biodiesel in India with a combined capacity of 1 MT per year. A 2009 directive from MPNG banned the use of biodiesel for transportation, so biodiesel producers have been forced to look for new markets for their product as a fuel for electricity generation. The West Bengal Pollution Control Board issued a directive that all telecom towers should use a minimum of $30 \%$ biodiesel to power their operation. At least one company has made supply arrangements with one telecom tower operator and is in discussion with more. ${ }^{362}$

\subsubsection{Technology Development and Transfer}

In India, efforts to develop advanced ethanol and biodiesel technologies are underway by various public and private research institutions, such as Praj Industries Ltd. (cellulosic ethanol and biodiesel), Indian Oil Corporation (cellulosic ethanol and algae), and the Department of Biotechnology (advanced feedstock development). These institutions work with research entities abroad to develop and transfer technologies.

\subsubsection{Local Case Studies}

Indian Railways is the largest consumer of diesel in the country with an annual expenditure on diesel fuel of INR 65 billion (USD 1.3 billion). Due to the high potential of cutting costs by using alternative sources, Indian Railways plans to use biodiesel (from Jatropha and other non-edible sources) for powering their locomotives. It will set up an integrated biodiesel plant in Chennai with a production capacity of 30 tonnes per day to gradually reduce dependence on high speed diesel, which is what is used now. Indian Railways would like to start with a $5 \%$ biodiesel blend and increase this up to $20 \%$ in coming years. The project is to be executed under a public-private partnership model and completed over 2 years. While the main goal is to reduce costs, other priorities include reducing GHG emissions and qualifying for carbon credits. $^{363}$

\subsubsection{Success Stories from the International Community and Potential Opportunities for India}

Betim, Brazil (population 440,000), is one of Brazil's first "model communities" for renewable energy, as part of a six-cities network that also includes Belo Horizonte, Porto Alegre, Salvadore, São Paulo, and Volta Redonda. Betim has established a number of policies to promote biofuels use in transportation. The city mandates biofuels in public buses and taxis and also gives preference to flex-fuel vehicles for municipal vehicle fleet purchases. The city is also facilitating the addition of SWH systems to a low-income housing project being built under a national program. A number of demonstration projects on municipal buildings have been carried out. Betim has also established a Renewable Energy Reference

\footnotetext{
${ }^{361}$ Jatropha World. http://www.jatrophabiodiesel.org/indianScene.php. Accessed August 2010.

${ }^{362}$ Mint. "Biodiesel Producers Looking for Tie-ups with Telecom Tower Firms." 22 April 2010. http://www.livemint.com/2010/04/21233621/Biodiesel-producers-looking-fo.html. Accessed July 2010.

${ }^{363}$ The Pioneer. "Rlys Looks at Bio-fuel to Cut Costs." 5 July 2010. http://www.dailypioneer.com/267113/Rlys-looks-at-bio-fuel-to-cut-costs.html. Accessed July 2010.
} 
Center that raises public awareness; provides information; brings together diverse stakeholders from local, state, and national levels; conducts training and workshops; and conducts outreach to other local communities in Brazil to share Betim's experience., ${ }^{, 364}$

${ }^{364}$ REN21. http://www.ren21.net/pdf/REN21 LRE2009 Jun12.pdf. Accessed August 2010. 


\section{Decentralized Energy}

\section{Chapter Overview}

Renewable technologies are ideally suited to distributed applications, and they have substantial potential to provide a reliable and secure energy supply as an alternative to grid extension or as a supplement to grid-provided power. According to IEA, in 2008, over 400 million people in India, including $47.5 \%$ of those living in India's rural areas, still had no access to electricity. Because of the remoteness of much of India's un-electrified population, renewable energy can offer an economically viable means of providing connections to these groups. The Government of India has initiated several programs, policies, and acts to improve rural livelihood with the help of renewable energy. They support electricity provision programs and organizations aiming to meet the full power requirements of a village including motive power and cooking energy. These programs have resulted in electrification of more than 90,000 villages and hamlets and free electricity connections have been provided to more than 12 million below poverty line (BPL) households. Renewable technologies also present opportunities for industries looking to establish captive power plants at their facilities to supplement grid power. Currently, renewable technologies represent only $1.2 \%$ of the total captive power installed capacity in India.

\subsection{Renewable Energy-Implication in Rural Electrification}

The lack of available modern energy services is a primary limitation to development, and providing access to electricity in a country of over one billion people, of which the majority lives in rural areas, is a gigantic task. Currently, many potential customers live in areas that are either physically inaccessible for a centralized power grid connection or where a connection is economically unviable, so creating decentralized energy supply solutions will be essential for stimulating development in these areas. In India, locally available, renewable sources such as solar energy, wind, biomass, or hydro energy are playing an increasingly prominent role in extending access to energy.

Sustainable electricity supply is mainly necessary for lighting, cooking, and comfort but also for watering agricultural fields. Growing demand due to the increase in population and more energy-intensive lifestyles has diminished the availability of dominantly used fuels in rural areas, such as wood, coal, and kerosene, which further underscores the need to shift to more sustainable energy supplies. Government initiatives to utilize locally available energy resources need private sector support and collaboration between various stakeholders to achieve the goals of energy security and energy sufficiency in rural areas of India.

At present, access to and availability of reliable and assured energy in India's rural areas is inadequate. According to IEA, in 2008, over 400 million people in India, including $47.5 \%$ of those living in India's rural areas, still had no access to electricity. ${ }^{365}$ Even those with electricity connections may periodically be unable to use it due to shortages or poor quality of supply resulting from inadequate infrastructure or inability to pay.

Households without access to electricity, whether in the electrified or un-electrified villages, continue to rely mostly on inefficient traditional biomass or kerosene. Fuel-wood, chips, and

\footnotetext{
${ }^{365}$ IEA. "The Electricity Access Database." http://www.iea.org/weo/database electricity/electricity access database.htm. Accessed October 2010.
} 
dung cakes contribute approximately $30 \%$ of the commercial energy consumed. ${ }^{366}$ To meet cooking energy needs, traditional biomass, heavily subsidized LPG, and kerosene are used by approximately $90.1 \%, 8.6 \%$, and $1.3 \%$ of rural households, respectively. ${ }^{367}$ Additionally, approximately $40 \%-60 \%$ of rural households use kerosene for lighting.

Some of the renewable energy technologies that are used in villages and rural areas as decentralized systems are:

- Family-size biogas plants.

- Solar street lighting systems.

- Solar lanterns and solar home lighting systems.

- Solar water heating.

- Solar cookers.

- Standalone solar power generators.

- Wind pumps.

- Micro-hydro power systems.

\subsubsection{Existing Policies and Relevant Programs for Rural Electrification}

As per the Electricity (Supply) Act 1948, ${ }^{369}$ in force until 2003, rural electrification was the responsibility of the state governments and SEBs. Therefore, non-conventional and renewable energy sources for these purposes were also promoted by the SEBs.

The Electricity Act 2003 made a specific provision of introducing national policies on standalone non-conventional energy systems in rural areas and electrification with local distribution to rural areas, and the pace of development of renewable energy sources has since increased substantially since this time.

The National Electricity Policy (February 2005) recognizes electricity as an essential requirement for all facets of life and as a basic human need. It also states that electricity supply at a reasonable rate to rural India is essential for India's overall development.

Three nodal ministries in the Government of India are focusing on the development of the rural economy by tapping local resources and providing subsidies and grants to energize growth and economic development.

- MoP: Promotes rural electrification.

- MNRE: Promotes use of renewable energy.

\footnotetext{
${ }^{366}$ IRADe and ENERGIA. "Gender Analyses of Renewable Energy in Inida - Present Status, Issues, Approaches and New Initiatives.” 2009; p. 11. http://www.irade.org/Gender\%20Cover.pdf. Accessed October 2010.

${ }^{367}$ Government of India. "Report of the Expert Group on a Viable and Sustainable System of Pricing of Petroleum Products." February 2010; p. 62. http://petroleum.nic.in/reportprice.pdf. Accessed October 2010

${ }^{368}$ Government of India. "Report of the Expert Group on a Viable and Sustainable System of Pricing of Petroleum Products.” February 2010; p. 62. http://petroleum.nic.in/reportprice.pdf. Accessed October 2010 and http://www.bioenergylists.org/stovesdoc/Nariphaltan/housenergy.pdf. Accessed October 2010.

${ }^{369}$ MoP. "Historical Background of Legislative Initiatives." http://www.powermin.nic.in/indian electricity scenario/pdf/Historical\%20Back\%20Ground.pdf. Accessed September 2010.
} 
- Ministry of Rural Development: Contributes to the living conditions, business, and economy in rural areas.

In October 1997, the Government of India defined "A village will be deemed to be electrified if electricity is used in the inhabited locality within the revenue boundary of the village for any purpose whatsoever." 370 The Indian government revised this in February 2004 so that villages must meet each of the following criteria before it is considered electrified:

“a) Basic infrastructure such as Distribution Transformer and Distribution Lines are provided in the inhabited locality as well as a minimum of one Dalit Basti/hamlet where it exists; and

b) Electricity is provided to public places like Schools, Panchayat Office, Health Centers, Dispensaries, Community Centers etc.; and

c) The number of households electrified are at least $10 \%$ of the total number of households in the village." 371

This changed the electrification status of many villages who were previously deemed electrified.

The Government of India has initiated several programs, policies, and acts that focus on the development of rural energy, economy, and electrification to improve rural livelihood with the help of renewable energy.

\subsubsection{Rajiv Gandhi Grameen Vidyutikaran Yojana -2005}

RGGVY is supported by MoP through the Rural Electrification Corporation. The targets of this program are to electrify 125,000 villages and to provide free electricity connections to 23.4 million BPL households. ${ }^{372}$ The program provides a $90 \%$ capital subsidy with the remainder of funds provided as a loan through the Rural Electrification Corporation. ${ }^{373}$ According to the International Energy Agency, the RGGVY is also designed to strengthen the existing network in 462,000 electrified villages until $2010^{374}$ by providing:

- Rural electricity distribution backbone for a cluster of villages by providing $33 / 11 \mathrm{kV}$ or $66 / 11 \mathrm{kV}$ substations of adequate capacity.

- Creation of village electrification infrastructure in every village including adequate distribution transformers.

- Decentralized distributed generation (DDG) and supply to provide electricity to villages from conventional or renewable sources on a standalone basis.

As RGGVY is focused on the provision of electricity and not the generation source, renewable energy is not necessarily promoted under this program; however, the DDG provision includes the use of renewable technologies. ${ }^{375}$ As of September 30, 2010, 84,618

\footnotetext{
${ }^{370}$ RGGVY. "Definition of Electrified Village." http:// rggvy.gov.in/rggvy/rggvyportal/def_elect_vill.htm. Accessed September 2010.

${ }^{371}$ MoP. "Rural Electrification Policy." p. 6. http://www.powermin.nic.in/whats new/pdf/RE\%20Policy.pdf. Accessed August 2010.

${ }^{372}$ RGGVY. http://www.rggvy.gov.in/rggvy/rggvyportal/index.html. Accessed October 2010.

${ }^{373}$ MoP. RGGVY brochure. http://recindia.gov.in/download/rggvy brochure.pdf. Accessed October 2010.

${ }^{374}$ IEA; Niez, A. "Comparative Study on Rural Electification Policies in Emerging Economies - Keys to Successful Policies. March 2010; p. 67. http://www.iea.org/papers/2010/rural_elect.pdf. Accessed October 2010.

${ }^{375}$ MoP. “Guidelines for DDG.” http://www.recindia.nic.in/download/DDG guidelines.pdf. Accessed October 2010 .
} 
villages have been electrified and over 12 million BPL households have received electricity connections. ${ }^{376}$

\subsubsection{Solar Mission}

JNNSM is supported by MNRE and MoP (see Chapter 4 for an overview of JNNSM). In addition to JNNSM's goals of $20 \mathrm{GW}$ of grid-tied solar by 2022, it aims to reach $2 \mathrm{GW}$ of off-grid solar installed capacity in the same time period. Under JNNSM, the first 1,000 MW of off-grid solar is to be installed by $2017 .{ }^{377}$ The central government is providing capital subsidies and low-interest loans for off-grid PV projects up to $100 \mathrm{~kW}$ for an individual site and up to $250 \mathrm{~kW}$ for a solar mini-grid. Subsidies are also available for off-grid solar thermal applications. ${ }^{378}$ As of August 31, 2010, almost $20 \mathrm{MW}$ of projects had been sanctioned by MNRE, more than half of which are in the state of Rajasthan. ${ }^{379}$

\subsubsection{Village Energy Security Programme}

The Village Energy Security Programme (VESP) is supported by MNRE and is designed to support all energy needs of villagers including domestic, commercial, agricultural, industrial, and motive power through test projects using locally available biomass. This program targets villages between 25-200 households and aims to support micro-enterprise development by providing energy for productive uses. To this end, it provides a $90 \%$ capital subsidy; operation and maintenance expenses are to be met through usage charges, and all remaining expenses are to be secured by the community, implementing agency, or state nodal agency. ${ }^{380}$ At the end of 2009, 80 test projects had been approved under VESP, and 54 of these had been commissioned. MNRE plans to complete the already approved test projects but currently has no plans to expand the program further. ${ }^{381}$

\subsubsection{Remote Village Electrification}

Remote Village Electrification (RVE) is supported by MNRE and aims to provide electricity to hamlets and villages with more than 300 inhabitants not covered under RGGVY and more than $3 \mathrm{~km}$ from the nearest point of grid access. The technology deployed under RVE is chosen by the state nodal agency after an assessment of renewable resource availability, and the Indian government provides a subsidy for installation up to $90 \%$ of actual costs. ${ }^{382}$ As of June 30, 2010, RVE activities had been completed for 6,867 hamlets and villages. ${ }^{383}$

\subsubsection{Programs of National Bank for Agriculture and Rural Development}

NABARD is set up as a development bank with the support of the Ministry of Finance with a mandate for facilitating credit flow for promotion and development of agriculture, small-scale industries, cottage and village industries, handicrafts, and other rural crafts (see Chapter 9).

\footnotetext{
${ }^{376}$ RGGVY. "Project Outlay, Coverage, and Progress So Far." http://www.rggvy.gov.in/rggvy/rggvyportal/plgsheet frame3.jsp. Accessed October 2010. ${ }^{377}$ MNRE. "Jawaharlal Nehru National Solar Mission. Toward building SOLAR INDIA." http://mnre.gov.in/pdf/mission-document-JNNSM.pdf. Accessed October 2010.

${ }_{378}$ MNRE. "Guidelines for Off-grid and Decentralized Application.” http://www.mnre.gov.in/pdf/jnnsmg170610.pdf. Accessed October 2010.

${ }^{379}$ MNRE. "Details of Projects Sanctioned Under Off-grid Solar Applications of JNNSM." http://www.mnre.gov.in/pdf/jnnsm-offgrid-project-sanctioned-as-on-31082010.pdf. Accessed October 2010.

${ }^{380}$ MNRE. "Test Pilots on Village Energy Security.” http://www.mnre.gov.in/adm-approvals/aa-vesp.pdf. Accessed October 2010.

${ }^{381}$ MNRE. Annual Report 2009-10. p. 36-37. http://mnre.gov.in/annualreport/200910EN/Chapter\%204/chapter\%204 1.htm. Accessed October 2010.

${ }^{382}$ MNRE. Annual Report 2009-10. p. 32. http://mnre.gov.in/annualreport/200910EN/Chapter\%204/chapter\%204 1.htm. Accessed October 2010.

${ }^{383}$ MNRE. “Achievements.” http://www.mnre.gov.in/achievements.htm. Accessed October 2010.
} 


\subsubsection{Business Models for Rural Electrification}

The Electricity Act 2003 gave private investors access to all power sector operations. As a consequence, state governments encouraged the private sector to invest in rural electrification projects. However, at present, the private sector is not independently active in village energybased commercial activities.

Many business models for rural economy development through renewable energy sources operate with the support of government programs. Some of the government programs succeeded, yet several programs did not fulfill the desired objective as revenue generation from these projects did not yield any tangible benefits.

Currently, a few of the business models are guiding progress towards desired objectives, such as SELCO (solar), NTPC (distributed generation), Appropriate Rural Technology Institute (ARTI) (biomass stoves), and ANKUR (scientific biomass). The following describes some of these business models.

\subsubsection{Biomass Gasifiers}

MNRE implements a program called "Biomass gasifier-based distributed/off-grid power programme for rural areas." 384 This program to deploy biomass gasifier systems for meeting unmet electricity demand in villages is implemented through state nodal agencies ${ }^{385}$ with the involvement of either energy service companies, cooperatives or Panchayats, NGOs, manufacturers or entrepreneurs, and central finance assistance (CFA). State nodal agencies are responsible for initiating, promoting, supporting, and coordinating all activities concerning new and renewable energy within each state. Some components, which are funded by the CFA, focus on human resource development and training (operation and maintenance; management) and support for gasifier manufacturers and suppliers to establish service centers in areas near the location that the biomass gasifiers are installed. ${ }^{386}$

Sustainable funding models are also developed in the villages, although the capital costs for the biomass gasifiers are funded through Government of India grants. The payable electricity charge is collected from each household, and the operation and maintenance costs are met by the Village Energy Committee or the entrepreneur. Figure 7-1 depicts material and financial flows for a village-level biomass gasifier.

\footnotetext{
${ }^{384}$ Ashkay Urja. "Biomass Gasifier-based Distributed/Off-grid Programme.” Vol. 3, Iss. 3, 2009; pp. 15-18. http://www.mnre.gov.in/akshayurja/dec09-e.pdf. Accessed October 2010.

${ }^{385}$ State Nodal Agencies are agencies at the state level that act as implementing agencies for renewable energy programs in their areas. The list of MNRE's state nodal agencies can be found at http://www.mnre.gov.in/list/snas.htm. ${ }^{386}$ Ashkay Urja. "Biomass Gasifier-based Distributed/Off-grid Programme." Vol. 3, Iss. 3, 2009; pp. 15-18. http://www.mnre.gov.in/akshayurja/dec09-e.pdf Accessed October 2010.
} 


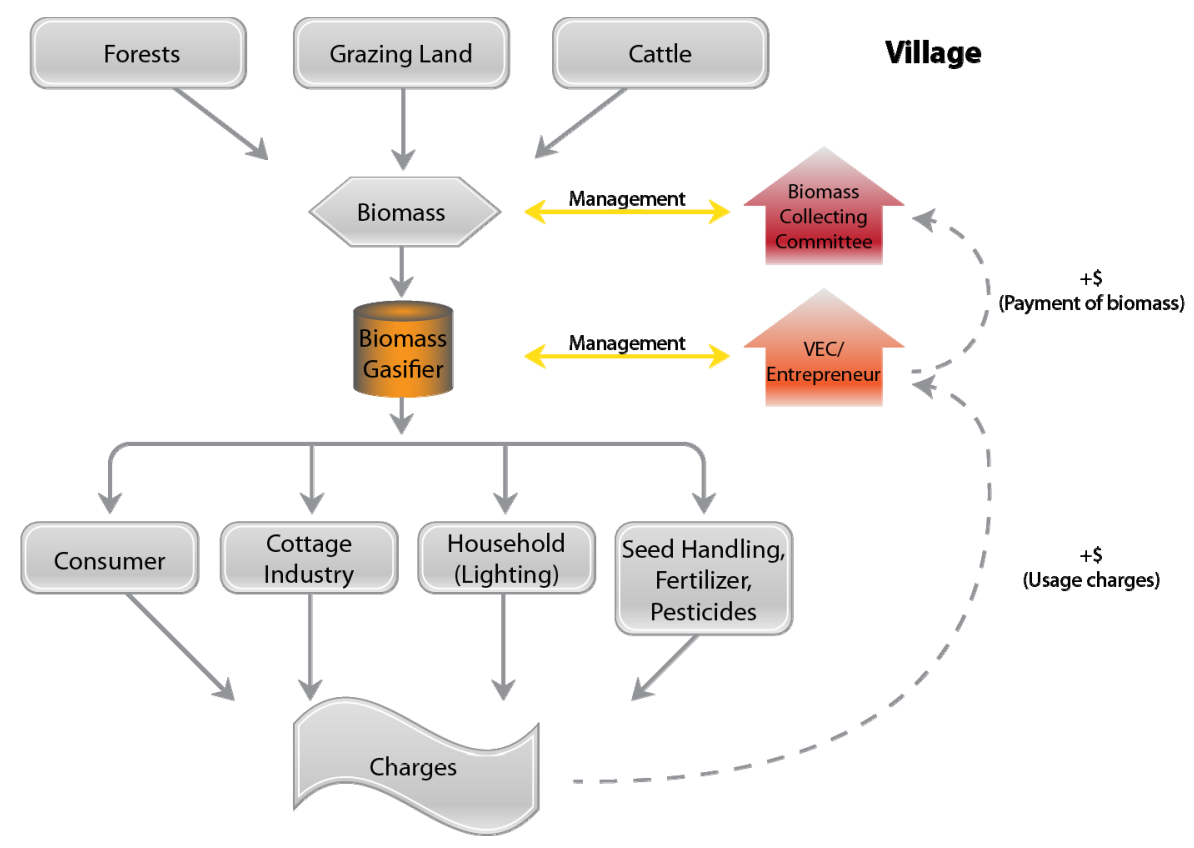

Figure 7-1. Rural energy through biomass gasifier: Business model

Source: IRADe created this figure based on information from MNRE.

\subsubsection{Biomass Stoves}

ARTI developed a project to disseminate improved cook stoves and improved fuels while also building up a sustainable network of manufacturers and marketers of the technology. At the end of the pilot stage, 120 rural businesses across Maharashtra had sold improved stoves to approximately 75,000 households. ARTI plans to scale up the program to reach 1.5 million households in Maharashtra and 50,000 in Gujarat with engagement of self-help groups, rural entrepreneurs, and NGOs. ${ }^{387}$

\subsubsection{SELCO Business Model}

SELCO-India is a private business that supplies PV solar home systems to provide power for lighting and small appliances to low-income households and institutions in Karnataka and Gujarat. SELCO's business model is based on the provision of product and service and providing access to financing through partnerships with banking institutions. ${ }^{388}$

SELCO has supported a business model for PV-powered battery-charging, in which an entrepreneur takes out a loan to purchase a solar lantern charging system and then rents out the solar lanterns to street vendors. Savings realized from no longer needing to purchase kerosene for lanterns are more than the rental costs of the solar lantern (see Figure 7-2). ${ }^{389}$

\footnotetext{
${ }^{387}$ ARTI. "Commercialisation of Improved Biomass Fuels and Cooking Devices in India: Scale Up PROJECT." http://www.arti-india.org/index.php?option=com_content\&view=article\&id=44\&Itemid=92. Accessed October 2010 .

${ }^{388}$ Ashden Awards. "Solar Photovoltaics Enabling Small Businesses to Develop." http://www.ashdenawards.org/files/reports/SELCO2007technicalreport.pdf. Accessed October 2010. ${ }^{389}$ SELCO. "Access to Sustainable Energy Services via Innovative Financing. 7 Case Studies." http://www.selco-india.com/pdfs/selco booklet_web.pdf. Accessed October 2010.
} 


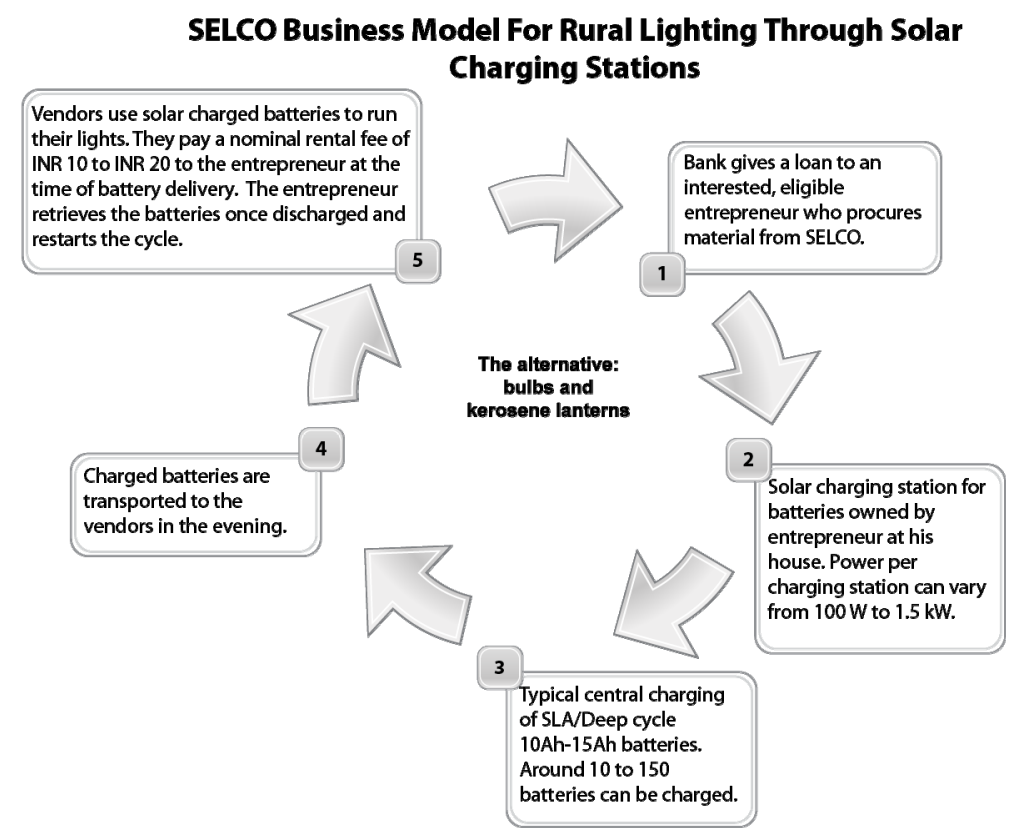

Figure 7-2. SELCO business model $\left.\right|^{390}$

\subsubsection{Micro-hydro Power Systems-A Success Story of Rural Electrification with Renewable Energy in Orissa}

Integrated Rural Development of Weaker Sections in India supported development of a 25 $\mathrm{kW}$ micro-hydro project in the village of Putsil in the Koraput district of Orissa. This system is designed to supply electricity to surrounding households, the battery-charging station, the grinder/milling machine in the village, and the village community center. The project was commissioned in 1999 after 2 years of intensive interaction with the community.

There is a committee overseeing plant operations, and each family in the community pays a fixed fee for use of the power generated. Members of neighboring communities also pay for use of the mill; half of this revenue stream goes into the community fund, which is to pay for the maintenance of the plant. Along with power generation, the micro-hydro project enhances income-generating activities in the region. ${ }^{391}$

\subsection{Captive Power for Industries}

According to the Electricity Act 2003, a captive power plant “... means a power plant set up by any person to generate electricity primarily for his own use and includes a power plant set up by any cooperative society or association of persons for generating electricity primarily for use of members of such cooperative society or association." 392

The opportunities that emerged after the enforcement of the Electricity Act 2003, including de-licensing generation, implementing open access, and setting up a common trading platform, have made the captive power plants an attractive option for industries to meet their

\footnotetext{
${ }^{390}$ SELCO. "Financing Solar Photovoltaic Systems through Rural Finance Institutions." http://enviroscope.iges.or.jp/contents/APEIS/RISPO/inventory/db/pdf/0002.pdf. Accessed October 2010. 391 WIDA. "Integrated Rural Development of Weaker Sections in India.” http://www.indg.in/pdffiles/IRDWSI_casestudy.pdf. Accessed October 2010.

${ }^{392}$ CEA. "The Electricity Act, 2003." http://www.powermin.nic.in/acts_notification/electricity_act $2003 /$ pdf/The $\% 20$ Electricity $\% 20$ Act 2003.pdf.
} Accessed October 2010. 
in-house requirement and sell surplus power from their captive plants to the grid, which helps the country in meeting power shortage conditions. Apart from the mentioned benefits, others include claiming incentives under CDM and earning RECs, which are going to be launched in India soon.

\subsubsection{Captive Power Plants in India}

At present, there are about 2,759 industrial units using captive generation power plants with a capacity of $1 \mathrm{MW}$ and above. Most industries supplying their own power are producers of aluminum, cement, chemicals, fertilizers, iron and steel, paper, and sugar, and they use their captive power plants to supplement the electricity purchased from utilities or for emergency use in case of power cuts, restrictions, or failures. As of March 31, 2008, the installed capacity of $1 \mathrm{MW}$ or greater captive power plants in the country was $24,986 \mathrm{MW}$, as seen in Table 7-1.

Table 7-1. All India Captive Power Plants of Industry (1 MW and Above) ${ }^{393}$

\begin{tabular}{|l|l|l|l|l|}
\hline \multicolumn{1}{|c|}{ Source } & \multicolumn{1}{|c|}{$\begin{array}{c}\text { Installed } \\
\text { Capacity (MW) }\end{array}$} & \% share & \multicolumn{1}{|c|}{$\begin{array}{c}\text { Gross } \\
\text { Generation } \\
\text { (GWh) }\end{array}$} & \% share \\
\hline Hydro & 60 & 0.24 & 202 & 0.22 \\
\hline Thermal & 24,621 & 98.54 & 89,892 & 99.36 \\
\hline- Steam & $-11,764$ & -47.08 & $-53,569$ & -59.21 \\
\hline- Diesel & $-8,648$ & -34.61 & $-10,738$ & -11.87 \\
\hline - Gas & $-4,209$ & -16.85 & $-25,585$ & -28.28 \\
\hline $\begin{array}{l}\text { Renewable } \\
\text { Energy }\end{array}$ & 305 & 1.22 & 383 & 0.42 \\
\hline Total & $\mathbf{2 4 , 9 8 6}$ & $\mathbf{1 0 0}$ & $\mathbf{9 0 , 4 7 7}$ & $\mathbf{1 0 0}$ \\
\hline
\end{tabular}

These plants generated 90,477 GWh during 2007-2008, which represents a growth of $10.61 \%$ from the total $81,800 \mathrm{GWh}$ generated in 2006-2007. Almost all of the generation is from thermal resources, and only very small contributions come from large hydro plants $(0.22 \%)$ and renewable energy resources $(0.42 \%)$. Out of a total generation of $90,477 \mathrm{GWh}$, the energy export to utilities was $7,456 \mathrm{GWh}$, or $8.2 \%$ of the total.

The representation of renewable technologies in the total installed capacity of captive power plants is only $305 \mathrm{MW}$, or $1.22 \%$ of total installed captive power generation capacity. The current capacity is primarily provided by wind turbines located mainly in the southern and western regions of India. The details of captive power installed capacity and generation from wind power plants are given in Table 7-2.394

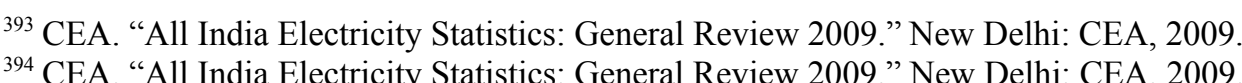


Table 7-2. Wind Power Plant Installed Capacity and Generation at Captive Power Facilities

\begin{tabular}{|l|l|l|l|}
\hline \multicolumn{1}{|c|}{ State } & Region & Installed Capacity (MW) & Gross Generation (GWh) \\
\hline Gujarat & Western & 75.19 & 84.82 \\
\hline Maharashtra & Western & 16.00 & 14.16 \\
\hline Chattisgarh & & 2.50 & 0 \\
\hline Andhra Pradesh & Southern & 2.03 & 0 \\
\hline Karnataka & Southern & 10.14 & 23.15 \\
\hline Tamil Nadu & Southern & 198.89 & 261.3 \\
\hline Total & & $\mathbf{3 0 4 . 7 5}$ & $\mathbf{3 8 3 . 4 3}$ \\
\hline
\end{tabular}

The wind-based captive power plants are owned by different industries, with the textile industry holding the largest share followed by the chemical, iron and steel, light engineering, and cement industries. Not included in these statistics is the bagasse cogeneration of the sugar industry, which is approximately 1,027 MW. Capacity and generation by industry is shown in Table 7-3. ${ }^{395}$

Table 7-3. Renewable Energy Installed Capacity and Generation by Industry

\begin{tabular}{|l|l|l|}
\hline \multicolumn{1}{|c|}{ Industry } & Installed Capacity (MW) & Gross Generation (GWh) \\
\hline Textile & 92.60 & 159.30 \\
\hline Chemical & 46.63 & 48.61 \\
\hline Iron \& Steel & 41.0 & 25.91 \\
\hline Light Engineering & 29.59 & 36.49 \\
\hline Cement & 24.47 & 32.08 \\
\hline Others (Balance) & 70.46 & 81.04 \\
\hline $\begin{array}{l}\text { Total (Wind } \\
\text { Power) }\end{array}$ & $\mathbf{3 0 4 . 7 5}$ & $\mathbf{3 8 3 . 4 3}$ \\
\hline Sugar & $1,027.17$ & $3,317.4$ \\
\hline
\end{tabular}

\subsubsection{Expansion of Renewable Energy in Captive Power Plants}

Captive power generation remains an area of opportunity for several renewable technologies.

\subsubsection{Wind Power}

The industry may continue to set up large capacity wind farms in the states where potential is still available, feed the power into the grid, and utilize equal amounts of power through the

${ }^{395}$ CEA. “All India Electricity Statistics: General Review 2009.” New Delhi: CEA, 2009. 
state grid at the location of their industry. Alternately, wind power plants can be sited on industry premises. These plants could be developed with suitable storage facilities to meet onsite electric requirements.

\subsubsection{Solar Power}

Industry captive power plants can use solar technologies on rooftops or in parks or other open spaces to meet factories' lighting loads and pumping water requirements.

Additionally, solar thermal power plants can be integrated in existing industries such as paper, dairy, or sugar, which have steam turbines set for cogeneration. Typically these cogeneration units have 5-250 MW capacity and can be coupled with solar thermal power plants. This approach will reduce the capital investment on steam turbines and associated power-house infrastructure, thus reducing the cost of generating solar electricity. The integration of a solar thermal power generation unit with existing coal thermal power plants could be profitable. Savings up to $24 \%$ are possible during periods of high insolation for feed water heating to $241^{\circ} \mathrm{C} .^{396}$

SWHs can serve low-temperature $\left(<80^{\circ}\right)$ needs for industrial facilities using current technology, but industrial process heat requires up to $250^{\circ}$ for advanced technologies. MNRE is supporting $\mathrm{R} \& \mathrm{D}$ of high-temperature process heat powered by solar thermal devices to serve the needs of such industries. ${ }^{397}$

\subsubsection{Biodiesel}

Another area that can increase renewable energy captive power is agricultural plantations of fuel crops, such as Jatropha, used for the production of biodiesel. The industry can use biodiesel to run oil-based diesel generator sets and earn RECs and CDM benefits. However, biodiesel does not yet play a decisive role in captive power generation.

\subsubsection{Other Sources}

Other renewable sources such as ocean waves, ocean thermal energy, and geothermal are site-specific and require a lot of expenditure on surveys, investigation, and R\&D. Therefore, these renewable sources are currently not used for captive power plants.

\footnotetext{
${ }^{396}$ Kalogirou, S.A. "Solar Thermal Collectors and Applications.” Prog. Energy and Combust. Sci.; Vol. 30, No. 3, 2004; pp. 231-295.

${ }^{397}$ MNRE. "Solar Thermal Energy. Thrust Areas for Research and Development." http://www.mnre.gov.in/stthrust.htm. Accessed October 2010.
} 


\section{Technology Transfer}

\section{Chapter Overview}

Technology transfer, or the application of internationally developed technologies, is considered to be an important element of a low carbon growth strategy for the Indian economy. Industrialized countries still have a technological lead in a number of renewable energy technologies and it would be desirable - from a global climate change mitigation perspective - to implement them as soon and as widely as possible in India. Transfer of low carbon technologies is considered a key element in combating climate change under the UNFCCC. ${ }^{398}$

Most renewable technologies, perhaps with the exception of solar thermal, geothermal, and offshore wind technologies, already have a strong domestic technology base through Indian companies and international companies in India. India is no longer just a recipient of technologies but increasingly a developer of technologies itself and a strong international competitor in the renewable energy space, as shown in companies such as Suzlon or Moser Baer. Not all renewable technologies are well established in India, but all are being improved upon, and new technologies are continually being commercialized. Much of this research and innovation happens outside India, so there remains a continuous need for technology transfer into India. This can be supported in the public sector through effective capacity building. At the same time, technology transfer from the private sector can be facilitated through an understandable regulatory environment, access to finance, and strong intellectual property protection.

\subsection{The Role of the Private and Public Sector in Technology Transfer}

A technology transfer typically includes the transfer of the technology design as well as the transfer of the property rights necessary to reproduce the technology in a particular domestic context. A common form of property right included in a technology transfer is a patent license: a legal agreement granting permission to make or use a patented article for a limited period or in limited territory. While the discussion on technology transfer is often held at political levels, it is important to consider that most technologies are not owned by governments but by private corporations. The diffusion of advanced technologies is often driven by multinational companies that want to exploit market opportunities in new regions. From this perspective, technology transfer means the creation of attractive conditions in India for the execution and manufacturing of renewable energy components and applications.

The public sector, which includes the Indian government as well as bilateral and multilateral institutions, plays an important role. Many renewable energy technologies are not yet commercially viable, and in order to thrive, they still depend on incentives given by the public sector. ${ }^{399}$ The public sector can also help reduce risks in the market by providing assurances to industries and investors venturing into new or risky technologies or by initiating demonstration projects.

\footnotetext{
${ }^{398}$ United Nations. Division for Sustainable Development. "Agenda 21: Transfer of Environmentally Sound Technology, Cooperation \& Capacity-Building." Section IV: Means of Implementation; Chapter 34. United Nations Conference on Environment and Development in Rio de Janeiro: Earth Summit, UN 1992. http://www.un.org/esa/dsd/agenda21/res_agenda21_34.shtml. Accessed August 2010. ${ }^{399}$ Ockwell, D.; Watson, J.; MacKerron, G.; Pal, P.; Yamin, F.; Vasudevan, N.; Mohanty, P. "UK-India Collaboration to Identify the Barriers to the Transfer of Low Carbon Energy Technology." March 2007. http://www.sussex.ac.uk/sussexenergygroup/documents/uk india full pb12473.pdf. Accessed October 2010.
} 
The Indian government, aided by private enterprises and international partners, is also playing an important role in creating relevant educational centers, research hubs, and technology clusters. Furthermore, in a country with such a significant gap in incomes, such as India, it seeks to support the spread of crucial technology to poorer segments of society. This could be called an "internal" technology transfer.

Most importantly, however, the Indian government will decide on the long-term energy strategy and make far-reaching decisions on such issues as the desired mix of energy sources, distribution networks, and electricity pricing.

International platforms such as the international climate change negotiations play an important role as well. They discuss the overall cost associated with climate change mitigation and adaptation and can propose solutions, best practice examples, and financial support or compensation across countries. Moreover, issues such as import tariffs or property rights may be discussed on the international level.

\subsection{Technology Transfer Through the Private Sector: Opportunities and Barriers}

As pointed out in the chapters before, India is an attractive and growing market and is rapidly becoming a key market for renewable energy technologies. The country offers opportunities to investors across the different technologies - wind, small hydro, biomass, solar, and, perhaps soon, emerging technologies such as geothermal and tidal energy - and along the value chain-from component manufacturing to investment, project development, power production, service and maintenance, and training and education.

\subsubsection{Market Opportunities per Technology}

In general, achieving a low price-level is a crucial factor for success of almost all offerings in the Indian market. For the international business community, that will often require localization: setting up a local office or manufacturing unit to become price competitive and understanding the market. Localization could lead to entering into some form of partnership with an Indian company, adapting products and business practices to Indian requirements, and, in the longer term, developing new products in India. India offers great opportunities to international companies to invest in India and bring their technologies to the market.

\subsubsection{Wind}

India has a strong wind market with consistently high growth rates and a long track record, and most wind technologies are locally available. Given a very competitive environment with low and falling costs, the technology may soon reach grid parity.

Being a mature market, the overall growth rate has declined in recent years. ${ }^{400}$ There is a shift towards new markets (e.g., new states and offshore) and a need for replacement of older windmills by new and bigger ones. ${ }^{401}$

The growth in the wind market is mainly driven by the still untapped potential and improvements in technology, which lead to increasing capacity factors and turbine sizes combined with decreasing installation cost. Given the current trend towards GBIs, achieving the maximum possible electricity generation becomes crucial. This, in turn, increases the

\footnotetext{
${ }^{400}$ GWEC. "Global Wind Report 2008." http://www.gwec.net/fileadmin/documents/Global\%20Wind\%202008\%20Report.pdf. Accessed October 2010. ${ }^{401}$ GWEC. "Indian Wind Energy Outlook 2009." http://www.indianwindpower.com/pdf/GWEO A4 2008 India LowRes.pdf. Accessed August 2010.
} 
demand for professional project developers. On the manufacturing side, more and more Asian companies are entering the market and thus increasing competition for established players. However, the competitive pressure will be different in various parts of the value chain.

Offshore wind power potential has not been assessed systematically yet. Given India's long coastline and the wind energy potential there, it could play an important role in the future. ${ }^{402}$ A transfer of technologies from other countries that already use offshore wind power on a large scale (e.g., Germany) could be possible.

\subsubsection{Solar}

The PV sector is still in the early stages, with an installed grid-connected power capacity of 10.28 MW in March 2010. ${ }^{403}$ The long-term potential of solar power in India, given climatic conditions and the rapidly growing electricity requirements, is very attractive. The market is now set to grow significantly and is being driven by JNNSM. As the market begins to pick up speed, there is a particular need for professional EPC contracting and ample supply of silicon wafers and balance-of-system components. ${ }^{404}$

In terms of solar thermal power, there is a clearly discernible market gap in professional EPC services for setting up and running solar thermal power plants. India has very ambitious targets for the development of the technology, yet there are few companies globally who can execute on it.

\subsubsection{Small Hydro}

The development of small hydro (the total potential is estimated at around $15 \mathrm{GW}$ ) ${ }^{405}$ can contribute to both the national power supply and electrification of remote areas. MNRE's small hydro program currently focuses on reducing capital costs as well as improving reliability and average utilization of facilities. ${ }^{406}$

Small hydro is a well-established technology offering investors projects with a low technology risk and potentially a very attractive return. It currently has on average the lowest generation costs among all renewable energy technologies in India. ${ }^{407}$

\subsubsection{Biomass}

Solid biomass-based power generation (mainly captive cogeneration in the sugar industry) is well established in India. While Indian companies have a lot of experience in combustion of biomass, there still is a significant scope for improving the efficiency of many existing cogeneration plants and technologies.

Biogas has so far been used mainly for small, off-grid applications, but there is a trend towards large-scale applications. New and adaptable technologies are needed as well as

\footnotetext{
${ }^{402}$ Energy Alternatives India. "India Offshore Wind-Status, Trends, Potential." http://eai.in/blog/2010/04/india-offshore-wind-status-trends-potential.html. Accessed October 2010.

${ }^{403}$ MNRE. "National Solar Mission Document.” http://mnre.gov.in/pdf/mission-document-JNNSM.pdf. Accessed October 2010.

${ }^{404}$ MNRE. "Jawaharlal Nehru National Solar Mission: Towards Building SOLAR INDIA." http://mnre.gov.in/pdf/mission-document-JNNSM.pdf. Accessed August 2010.

${ }_{405}$ MNRE. Annual Report 2009-2010. http://mnre.gov.in/annualreport/2009-10EN/index.htm. Accessed October 2010.

${ }^{406}$ MNRE. “Small Hydro Power Programme.” http://www.mnre.gov.in/prog-smallhydro.htm. Accessed October 2010.

${ }^{407}$ Government of India Planning Commission. "Integrated Energy Policy: Report of the Expert Committee." 2006; p. 90. http://planningcommission.nic.in/reports/genrep/rep intengy.pdf. Accessed July 2010.
} 
logistical, biological, and agricultural expertise. Some Indian and international companies are exploring the technology of upgrading biogas to natural gas equivalent and feeding it into the gas grid.

A great opportunity exists for companies that are able to develop reproducible and sustainable business models and technologies that are applicable in a rural setting. This requires strong distribution channels and a service and maintenance network. Technologies need to be inexpensive, robust, and operational with various locally available feedstock.

\subsubsection{Barriers}

While being a very promising market for international investors, success in India requires good market knowledge, patience, and adaptability. The regulatory environment is complex and in flux. Products and business models may have to be changed to suit the Indian customer.

\subsubsection{Product-related Barriers}

Many technologies that are well established in developed countries may not be directly transferable to developing nations. ${ }^{408}$ Products from outside India may be too expensive due to high production costs in industrialized countries, and product design may not meet the needs of the Indian market or import tariffs. Products often have to be adapted to match market requirements regarding, for example, level of quality, robustness, and climatic conditions. Adaptation may also be needed in business models. To reach competitive price levels, localization of manufacturing, sourcing, or services may be required. ${ }^{409}$

The needs for product adaptation will likely be significantly lower if the technology originates in a country with a market comparable to India's. The Asia Clean Energy Forum, for example, held in Manila in June 2010, sought further cooperation in the renewable energy field from developing nations. ${ }^{410}$

\subsubsection{Market Information}

For foreign companies, a market entry into India is often made difficult by a lack of information about the legal, political, and market environment. The market for renewable energy is very dynamic and, in many sectors, not very transparent. This is partly due to the rapidly changing regulatory environment (such as in the field of solar energy). The federal setup of the Indian state, where individual states formulate policies to complement the Government of India, also plays a role. Especially in technologies such as biomass-based power generation, where local knowledge about land-ownership or agricultural production is essential, information is difficult to obtain.

\subsubsection{Infrastructure Availability}

Another important barrier in many places is the infrastructure. ${ }^{411}$ Limited road and grid availability may hamper plans for setting up new plants in remote regions. The hilly areas of

\footnotetext{
${ }^{408}$ Kathuria, V. "Technology Transfer for GHG Reduction: A Framework with Application to India." Tech. Forecasting \& Soc. Change, Vol. 69, 2002; pp. 405-430.

${ }^{409}$ Bridge to India Pvt. Ltd. and Technical University of Munich. "Research Project on Market Barriers for International Renewable Energy Companies in the Indian Market” Research report to be published in 2011. ${ }^{410}$ For detailed information, see http://www.cleanenergyasia.net/. Accessed August 2010.

${ }^{411}$ Ockwell, D.; Watson, J.; MacKerron, G.; Pal, P.; Yamin, F.; Vasudevan, N.; Mohanty, P. “UK-India Collaboration to Identify the Barriers to the Transfer of Low Carbon Energy Technology." March 2007. http://www.sussex.ac.uk/sussexenergygroup/documents/uk india full pb12473.pdf. Accessed October 2010.
} 
the Himalaya, for example, offer huge potential for small hydropower, which is only partially harnessed because of the limited availability of supporting infrastructure.

\subsubsection{Finance}

Financing is a problem in many infrastructure projects where there are high initial costs and a long-term planning horizon. In India, the availability of debt financing is limited due to the perceived risks in the market. These risks relate mostly to PPAs with state power utilities. These have a weak financial position, which raises questions about payment default on longterm PPAs. Also, there is only limited funding — equity and debt—available for new technologies. On the demand side, many Indian consumers may not have access to the capital needed for the higher initial costs of purchasing technologies such as home PV systems. ${ }^{412}$

\subsection{The Role of the Public Sector in Improving Technology Transfer}

In many sectors, the market for renewable energy is still a politically enabled market with many pre-commercial and supported-commercial technologies, such as solar PV. ${ }^{413}$

Therefore, support by the government and bilateral and multilateral institutions and initiatives is needed to enable further development and wider adoption of these technologies. In addition to governmental efforts, bilateral support is provided by industrial nations' development agencies, such as the UK Department for International Development, the German GTZ and KfW, or USAID. Different United Nations organizations (e.g., UNFCCC, World Bank, GEF, and IEA) offer multilateral support and provide international frameworks.

Public sector technology transfer activities will range from needs and resource assessments to selection and adaptation of the appropriate technology to the institutional strengthening required to support technology deployment (see Figure 8-1).

\footnotetext{
${ }^{412}$ U.S. Congress Office of Technology Assessment. "Fueling Development: Energy Technologies for Developing Countries.” OTA-E-516. Washington, DC: U.S. Government Printing Office, April 1992.

${ }^{413}$ Ockwell, D.; Watson, J.; MacKerron, G.; Pal, P.; Yamin, F.; Vasudevan, N.; Mohanty, P. "UK-India Collaboration to Identify the Barriers to the Transfer of Low Carbon Energy Technology." March 2007. http://www.sussex.ac.uk/sussexenergygroup/documents/uk india full pb12473.pdf. Accessed October 2010.
} 


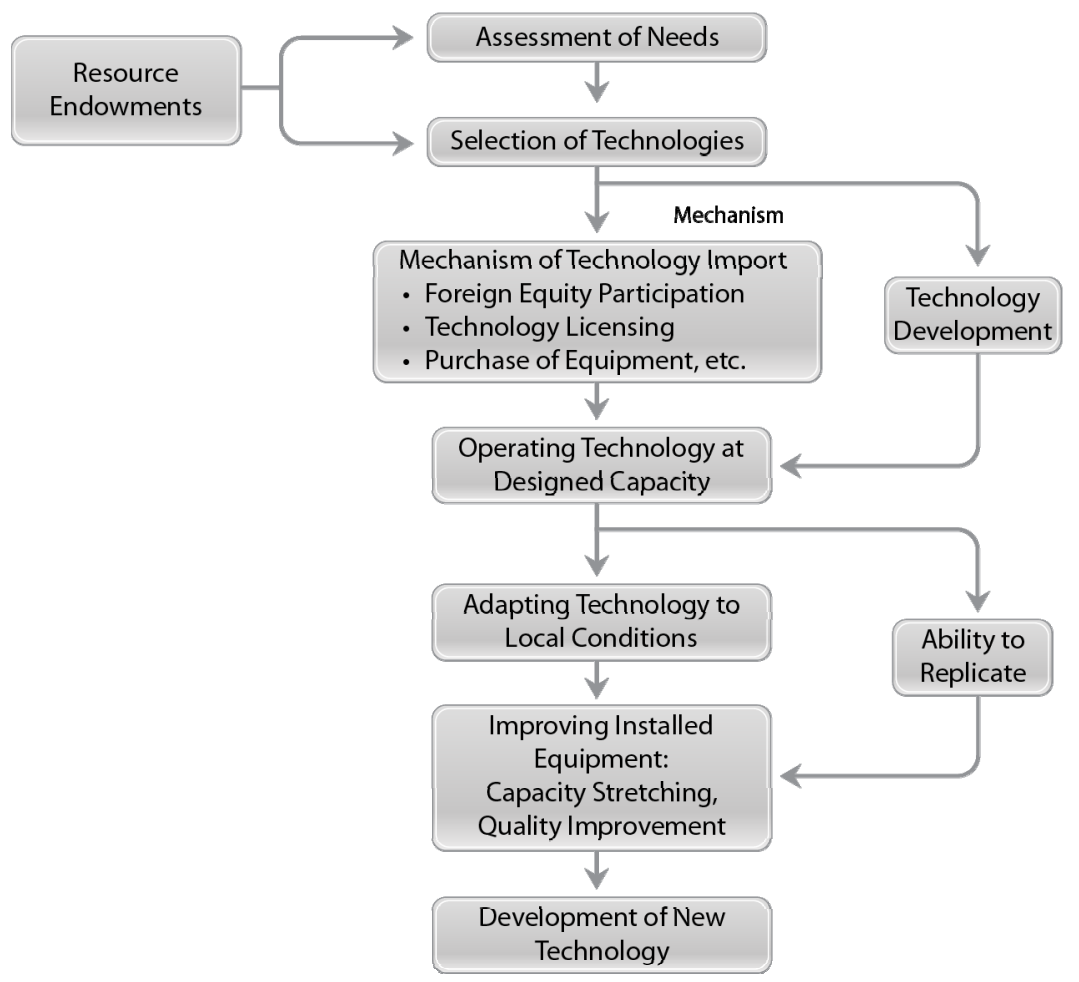

Figure 8-1. Steps in technology transfer ${ }^{414}$

\subsubsection{Creating Markets and Providing Incentives}

The most important factor limiting the faster spread of clean energy technologies is the relatively higher cost of power generation compared to subsidized alternatives such as fossil fuels. ${ }^{415}$ Through a variety of instruments including income tax incentives, preferential tariffs, demand-side measures, and the reduction of support given to fossil fuels, ${ }^{416}$ governments can influence the economics in favor of renewable energy.

Another important lever at the government's disposal is import duties and sales taxes. If renewable energy technologies are considered desirable and are supported by public funds, it may be counterproductive to levy high import duties or sales taxes on key components. For example, Finance Minister Pranab Mukherjee announced that the Indian government will exempt renewable machinery, such as solar equipment, parts for rotor blades used in wind turbines, and electric vehicles, from a tax on the production of goods. ${ }^{417}$

In the off-grid market, which is crucial in India, renewable energy solutions do not compete directly with cheap grid power. The government fosters not only international but also innerIndian technology transfer through creating viable local markets. This requires finding innovative ways to overcome the low purchasing power of consumers relative to the high costs of renewable energy technologies.

\footnotetext{
${ }^{414}$ Adapted by NREL from Parikh, J.; Kathuria, V. "Technology Transfer for GHG Reduction: A Framework and Case Studies for India.” Presented at STAP Workshop; January 19-20, 1997, Amsterdam, The Netherlands. ${ }^{415}$ Copenhagen Economics A/S and The IPR Company ApS. "Are IPR a Barrier to the Transfer of Climate Change Technology?" January 19, 2009; p. 32. http://trade.ec.europa.eu/doclib/docs/2009/february/tradoc_142371.pdf. Accessed August 2010.

${ }^{416}$ Recently the Government of India deregulated energy prices by linking local and international fuel prices. See "Fuel Price Deregulation is Here to Stay." The Hindu. 27 June 2010.

${ }^{417}$ India's Cleantech Economy. http://www.indianenergytech.com/2010/03/14/india-increases-national-actionon-climate-change. Accessed August 2010.
} 
The Indian 2010-2011 budget specified some key measures to increase the flow of renewable energy technology into the Indian market. The main points are: ${ }^{418}$

- Establish a National Clean Energy Fund for funding research and innovative projects in clean energy technologies.

- Levy a clean energy tax on coal produced in India (and imported into India) at a rate of INR 50 (USD 1) per ton to build the corpus of a National Clean Energy Fund.

- Increase the weighted deduction on expenditure incurred for in-house R\&D from $150 \%-200 \%$ to further encourage R\&D efforts. Enhance weighted deductions on payments made to national laboratories, research associations, colleges, universities, and other institutions for scientific research from $125 \%$ to $175 \%$.

- Require concessional customs duty provisions of 5\% to machinery, instruments, equipment, and appliances for initial set up of PV and solar thermal power generating units and exempt from central excise duty. Exempt ground-source heat pumps used to tap geothermal energy from basic customs duty and special additional duty.

- Complete liberalization of pricing and payment of technology transfer fees and trademark, brand name, and royalty payments.

\subsubsection{Support for Financial Markets}

The Indian government is looking at improving the financing frameworks of renewable energy projects. It can raise awareness among equity investors and banks regarding the profitability of renewable energy projects. Some investors lack experience and technical understanding. The government assists by providing information and developing standards as well as best practice guides to alleviate the appraisal for developers. For example, MNRE announced guidelines for wind power projects requiring the certification of wind turbines, which reduces the risks for investors. ${ }^{419}$

One of the key levers for improving international investor confidence in the Indian market is through provision of secure, long-term PPAs by the government. Key issues here are the credit status of the contract partners (often the SEBs) and the long-term outlook on feed-in tariffs and electricity prices in India.

Financial support by international donors and innovative financing options are still required in order to scale up investments in renewable energy technologies in India. For example, a renewable energy development project in cooperation by World Bank, GEF, and the Government of India was set up to improve commercial markets and the financing of renewable energy in India. The project promoted and financed various investments of the private sector through IREDA. IREDA carried out market campaigns and business trainings and provided subsidies and financial incentives. ${ }^{420}$

\footnotetext{
${ }^{418}$ Union Budget. "Key Features of Budget 2010-2011.” http://indiabudget.nic.in/ub2010-11/bh/bh1.pdf. Accessed August 2010.

${ }_{419}$ C-Wet. http://www.cwet.tn.nic.in/html/departments sc.html. Accessed September 2010.

${ }^{420}$ Martinot, E. "Methodological and Technological Issues in Technology Transfer," Chapter 16. Case Study 22. http://www.grida.no/climate/ipcc/tectran/350.htm. Accessed August 2010.
} 


\subsubsection{Research and Development and Capacity Building}

India wants to become an international leader not only in the use of renewable energy but also in the development and commercialization of new technologies. National policies, such as JNNSM have recognized that in order to achieve more rapid technology development, there is a need for financial assistance for research in India. Funds for research into the manufacturing of polysilicon, for example, are to be provided by the National Energy Fund. ${ }^{421}$ The Indian government also plans to set up a Solar Research Council, which would coordinate research activities in India according to the R\&D strategy of JNNSM. The strategy includes training, pilot demonstration projects, and National Centres of Excellence as research hubs and "incubators" for innovations and improvement of existing technologies. ${ }^{422}$

There is a clear need for bilateral and multilateral collaboration on R\&D of clean energy technologies. Sharing knowledge and experiences can reduce the costs and risks involved in a project. Examples of such cooperation are the Indo-U.S. Science \& Technology Forum, which catalyzes the bilateral collaborations in science, technology, and research with the funding vehicle for collaborative research provided under the EU's Framework Program.

Capacity building on the effective use of renewable energy technologies is also required. As a crucial aspect of capacity building, training must be imparted locally. Skills need to be improved to evaluate technological feasibility, cost benefit, applications, and local manufacturing capabilities.

An important example of such work in India is the Bureau of Energy Efficiency's (BEE) Energy Manager Training, ${ }^{423}$ which was developed in cooperation with GTZ. BEE publishes a list of certified energy managers and energy auditors on its Web site, ${ }^{424}$ and it is clear that this program has successfully created a pool of professionals working towards energy conservation and efficiency.

Support for capacity building is promoted internationally by the Expert Group on Technology Transfer and the UNFCCC, ${ }^{425}$ and the United Nations provides direct financial support (e.g., GEF, UNDP, and the World Bank) for trainings, seminars, and workshops.

\subsubsection{Legal and Institutional Issues}

An important barrier to the introduction of more international technologies in India is the limited enforceability of law. This is particularly relevant with regard to Intellectual Property Rights. Improvements in patent protection could also stimulate domestic innovation. There is a significant increase in resident patent holders for clean technologies in emerging market economies (33\% over 1998-2008). In China, approximately $40 \%$ of technology patents are locally owned compared to $14 \%$ in India. Moreover, climate change technology is not yet as heavily patented as biotechnology, agriculture, and information technology. ${ }^{426}$

\footnotetext{
${ }^{421}$ Government of India Planning Commission. "Eleventh Five Year Plan 2007-12: Volume III Agriculture, Rural Development, Industry, Services, and Physical Infrastructure.” p. 417. http://planningcommission.nic.in/plans/planrel/fiveyr/11th/11_v3/11th_vol3.pdf. Accessed August 2010.

${ }_{422}$ MNRE. http://mnre.gov.in/pdf/mission-document-JNNSM.pdf. Accessed September 11, 2010.

${ }^{423}$ Energy Manager Training. http://www.energymanagertraining.com. Accessed September 2010.

${ }^{424}$ BEE. http://www.bee-india.nic.in/. Accessed August 2010.

${ }^{425}$ UNIDO. "Technology Development and Transfer for Climate Change." Working Paper, March 2010, p. 31.

${ }^{426}$ Copenhagen Economics A/S and The IPR Company ApS. "Are IPR a Barrier to the Transfer of Climate Change Technology?" 19 January 2009; p. 5.

http://trade.ec.europa.eu/doclib/docs/2009/february/tradoc_142371.pdf. Accessed August 2010.
} 


\subsubsection{Clustering}

Through provision of land and tax incentives, the government can encourage the formation of clusters. These could in turn become centers of innovation and business development by concentrating technology specific resources, companies, and market knowledge. Thus, MNRE announced the development of 60 solar cities nationwide, with Nagpur in Maharashtra being the first one. MNRE funds half the costs of the project and requires a $10 \%$ reduction of energy consumption through combining improved energy efficiency with greater use of renewable energy sources. ${ }^{427}$

\subsubsection{Communication and Information Dissemination}

To improve the transfer of renewable energy technologies, an exchange of knowledge and information is required - not only about technical details, but also on the conditions under which a technology is applicable. ${ }^{428}$ One example of information dissemination is the special advisory service facilitating technology transfer in clean energy provided by the Asia Pacific Centre for the Transfer of Technology (APCTT). ${ }^{429}$ Under their program, "Supporting the Development of an Institutional Cooperation Mechanism to Promote Renewable Energy," APCTT facilitates the collection and dissemination of information on renewable energy technologies, shares best practices on promotion policies and utilization, and promotes R\&D collaboration. ${ }^{430}$

Another example is the Indo-German Energy Forum. One of its main objectives is to improve the development of clean energy technologies in the Indian market by promoting transfer of know-how and technology. Topics in the field of renewable energy include support for a solar center at a leading Indian university, piloting solar-energy-based water desalination technology, and developing bankable business models for the use of renewable energy in rural areas. Several other countries are also committed to an exchange of knowledge and technology.

\footnotetext{
${ }^{427}$ MNRE. "Development of Solar Cities.” http://www.mnre.gov.in/pdf/city-guidelines.pdf. Accessed September 11, 2010.

${ }^{428}$ UNIDO. “Technology Development and Transfer for Climate Change.” Working Paper, March 2010, p. 28.

${ }^{429}$ For detailed information, see http://technology4sme.net/home.aspx. Accessed August 2010.

${ }^{430}$ APCTT. "Renewable Energy Cooperation-Network for the Asia Pacific."

http://apctt.net.previewdns.com/solutioncentre/ResAssess.aspx. Accessed October 2010.
} 


\section{Financing Renewable Energy in India}

\section{Chapter Overview}

Clean energy investment worldwide reached INR 8,100 billion (USD 162 billion) in 2009. This number was down from INR 8,650 billion (USD 173 billion) in 2008 but was still the second highest annual figure ever and nearly four times the total investment in 2004 (INR 2,140 billion/USD 46 billion). The reduction between 2008 and 2009 can be mainly attributed to the recent economic crisis. ${ }^{431}$

Since 1990, India has been part of this boom in investment in renewable energy. According to a recent publication by the United Nations Environment Programme's Sustainable Energy Finance Initiative (SEFI) and Bloomberg New Energy Finance, total financial investment in clean energy in India was at INR 135 billion (USD 2.7 billion) in 2009, ranking it eighth in the world. ${ }^{432}$ With an increasingly favorable regulatory and policy environment and a growing number of entrepreneurs and project developers, India has been ranked by Ernst and Young as the fourth most attractive country for renewable energy investment in the world, only behind the United States, China, and Germany. ${ }^{433}$

Asset finance (renewable energy finance projects) and the public market are still the dominant forms of renewable energy financing in India; venture capital and private equity transactions are still limited in India due to the risks associated with renewable energy technologies. The confidence of domestic commercial banks providing loans to renewable projects is still limited; however, this is changing thanks to growing awareness and more and more favorable government policies and targets. Governments and bilateral and multilateral organizations are offering grants at favorable rates to promote renewable energy and project development, which is supporting deployment at all scales. India is also one of the most active participants in the CDM using revenues of carbon credits to finance renewable energy projects.

\subsection{Investment by Asset Class}

The majority of renewable energy financing in India over the past 5 years has been in asset financing through internal company balance sheets, debt finance, and equity finance. Although the total value of asset financing has fallen from INR 155 billion (USD 3.1 billion) in 2008 to INR 95 billion (USD 1.9 billion) in 2009, it still accounts for $70 \%$ of domestic renewable energy investments. Public market activity, money invested in the equity of publicly quoted companies developing renewable energy technology, efficiency, and clean power generation, was around INR 35 billion (USD 700 million) in 2009. ${ }^{434}$ The Indian stateowned hydropower company NHPC Limited, raised INR 65 billion (USD 1.3 billion) via an initial public offering on the Indian National Stock Exchange and Bombay Stock Exchange during the year. Indian companies began to explore foreign stock exchanges as an additional source of funds in 2007 and raised INR 37.8 billion (USD 756 million) on the Singapore Stock Exchange and London's AIM in that year, compared to INR 32.3 billion (USD 646

\footnotetext{
${ }^{431}$ UNEP SEFI and Bloomberg New Energy Finance. "Global Trends in Sustainable Energy Investment 2010 Analysis of Trends and Issues in the Financing of Renewable Energy and Energy Efficiency." 2010; p. 8.

${ }^{432}$ UNEP SEFI and Bloomberg New Energy Finance. "Global Trends in Sustainable Energy Investment 2010 Analysis of Trends and Issues in the Financing of Renewable Energy and Energy Efficiency." 2010; p. 8.

${ }^{433}$ Ernst \& Young. "Renewable Energy Country Attractiveness Indices." p 10.

http://www.ey.com/Publication/vwLUAssets/Renewable_energy_country_attractiveness indices_Issue 25/\$FIL E/Renewable Energy_Issue_25.pdf. Accessed September 2010.

${ }^{434}$ UNEP SEFI and Bloomberg New Energy Finance. "Global Trends in Sustainable Energy Investment 2010 Analysis of Trends and Issues in the Financing of Renewable Energy and Energy Efficiency.” 2010; p. 48.
} 
million) on domestic exchanges. ${ }^{435}$ However, due to financial turmoil in 2008, those funding avenues dried up with no money raised internationally in 2008 and only INR 3.7 billion (USD 74 million) raised on Indian exchanges. ${ }^{436}$ Venture capital and private equity activity in India marked a very small proportion of all investments in 2009 at just $4 \%$ of the clean energy total of INR 5 billion (USD 100 million), down from INR 20 billion (USD 400 million) in $2008 .^{437}$

Table 9-1. New Financial Investment in India by Sector and Asset Class, $2009^{438}$

\begin{tabular}{|l|l|l|l|l|l|l|l|l|}
\hline $\begin{array}{c}\text { Sector/Asset } \\
\text { Class }\end{array}$ & \multicolumn{2}{|c|}{ Asset Finance } & \multicolumn{2}{c|}{ Public Markets } & \multicolumn{2}{c|}{$\begin{array}{l}\text { Venture Capital/ } \\
\text { Private Equity }\end{array}$} & \multicolumn{2}{c|}{ Total } \\
\hline & $\begin{array}{l}\text { billion } \\
\text { INR }\end{array}$ & $\begin{array}{l}\text { million } \\
\text { USD }\end{array}$ & $\begin{array}{l}\text { billion } \\
\text { INR }\end{array}$ & $\begin{array}{l}\text { million } \\
\text { USD }\end{array}$ & $\begin{array}{l}\text { billion } \\
\text { INR }\end{array}$ & $\begin{array}{l}\text { million } \\
\text { USD }\end{array}$ & $\begin{array}{l}\text { billion } \\
\text { INR }\end{array}$ & $\begin{array}{l}\text { million } \\
\text { USD }\end{array}$ \\
\hline Solar & 2.5 & 50 & 1 & 20 & 1.5 & 30 & 5 & 100 \\
\hline Biofuels & 5 & 100 & 5 & 100 & 0 & 0 & 10 & 200 \\
\hline Small Hydro & 10 & 200 & 0 & 0 & 0 & 0 & 10 & 200 \\
\hline $\begin{array}{l}\text { Biomass and } \\
\text { Waste-to-energy }\end{array}$ & 25 & 500 & 0 & 0 & 5 & 100 & 30 & 600 \\
\hline Wind & 50 & 1,000 & 30 & 600 & 0 & 0 & 80 & 1,600 \\
\hline
\end{tabular}

From a technology perspective, the largest portion of new investment went to the wind sector at INR 80 billion (USD 1.6 billion), which represented 59\% of the national total and was $11 \%$ higher than the investment in wind in 2008. Biomass (including waste-to-energy) received the second largest sector portion of new investment at INR 30 billion (USD 0.6 billion), followed by small hydro and biofuel investments, each at INR 10 billion (USD 0.2 billion). ${ }^{439}$ With the release of JNNSM targeting $22 \mathrm{GW}$ of installed solar capacity by 2022 at an estimated cost of approximately INR 27.96 billion (USD 932 million), a substantial increase in investments into solar power is expected. ${ }^{440}$ Approval of the 2009 National Biofuels Policy, targeting $20 \%$ biodiesel and ethanol blends in fuels by 2017 , will also likely trigger an increase in investment. ${ }^{441}$

\subsection{Various Types of Financing}

Traditionally, the government and NGOs have provided most of the funding for environmental or sustainable development projects in India. The main government funding

${ }^{435}$ UNEP. "Global Trends in Sustainable Energy Investment 2009. Analysis of Trends and Issues in the Financing of Renewable Energy and Energy Efficiency." 2009; p. 49.

http://www.unep.org/pdf/Global trends report 2009.pdf. Accessed October 2010.

${ }^{436}$ UNEP. "Global Trends in Sustainable Energy Investment 2009. Analysis of Trends and Issues in the Financing of Renewable Energy and Energy Efficiency." 2009; p. 49.

http://www.unep.org/pdf/Global trends report 2009.pdf. Accessed October 2010.

${ }^{437}$ UNEP. "Global Trends in Sustainable Energy Investment 2010 - Analysis of Trends and Issues in the Financing of Renewable Energy and Energy Efficiency.” 2010; p. 48.

http://bnef.com/DownloadDt3/download/UserFiles/File/WhitePapers/sefi_unep_global_trends_2010.pdf. Accessed October 2010.

${ }^{438}$ UNEP. "Global Trends in Sustainable Energy Investment 2010 - Analysis of Trends and Issues in the Financing of Renewable Energy and Energy Efficiency.” 2010; p. 48.

http://bnef.com/DownloadDt3/download/UserFiles/File/WhitePapers/sefi_unep_global_trends_2010.pdf. Accessed October 2010.

${ }^{439}$ UNEP. "Global Trends in Sustainable Energy Investment 2010 - Analysis of Trends and Issues in the Financing of Renewable Energy and Energy Efficiency.” 2010; p. 48.

http://bnef.com/DownloadDt3/download/UserFiles/File/WhitePapers/sefi_unep_global_trends_2010.pdf. Accessed October 2010.

${ }^{440}$ MNRE. "Jawaharlal Nehru National Solar Mission Towards Building SOLAR INDIA."

http://mnre.gov.in/pdf/mission-document-JNNSM.pdf. Accessed August 2010.

${ }^{441}$ Commodity Online. http://www.commodityonline.com/news/India-approves-National-Policy-on-bio-fuels24194-3-1.html. Accessed August 2010. 
body has been IREDA, who offers standard loans to renewable energy projects at rates slightly more favorable than general commercial lending rates (see Chapter 2 for more an overview of IREDA's activities). ${ }^{442,443,444}$

As of December 31, 2009, IREDA financed 1,921 projects with IREDA loan commitment amounts totaling over INR 121.8 billion (USD 2.4 billion). Between 1987 and 2009, actual IREDA disbursements are at INR 66 billion (USD 1.41 billion). Such funding has supported the installation of $4.38 \mathrm{GW}$ of power generation capacity. IREDA's loan commitments during 2008 were over INR 14.9 billion (USD 300 million) for 47 projects totaling $403 \mathrm{MW}$ of power generation; 2008 loan disbursements were over INR 7.7 billion (USD 154 million). ${ }^{445}$ Other government agencies that actively fund renewable energy projects are the PFC, the Rural Electrification Corporation, and NABARD. ${ }^{446}$ Some typical financial products and services are summarized in Table 9-2.

\footnotetext{
${ }^{442}$ Cleantech Group LLC. “Cleantech Venture Capital and Private Equity Investments in India.” 2008; p. 15.

${ }^{443}$ IREDA, http://www.ireda.gov.in/. Accessed August 2010.

${ }^{444}$ Cleantech Group LLC. "Cleantech Venture Capital and Private Equity Investments in India." 2008; p. 15.

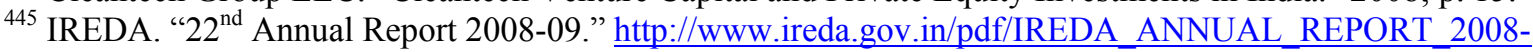
09.pdf. Accessed August 2010.

${ }^{446}$ The table used extracted information from the official Web sites of PFC http://www.pfc.gov.in/, Rural Electrification Corporation Limited http://www.recindia.nic.in/, and NABARD http://www.nabard.org/. Accessed August 2010.
} 
Table 9-2. Financial Institutions and Services

\begin{tabular}{|c|c|}
\hline Name of Institution & Type of Financing \\
\hline IREDA & $\begin{array}{l}\text { Finances up to } 70 \% \text { of project cost with interest rates between } 1.75 \% \text { and } \\
10.50 \% \text { in the following sectors: } \\
\text { 1) Hydro power projects } \\
\text { 2) Wind energy: Rebate at } 0.25 \% \text { for a period of } 2 \text { years for projects } \\
\text { eligible for GBI } \\
\text { 3) Biomass cogeneration and industrial cogeneration } \\
\text { 4) Solar PV/solar thermal grid-connected power projects } \\
\text { 5) Energy conservation/efficiency projects (including DSM) and } \\
\text { projects implemented in ESCO mode } \\
\text { Finances electrification of remote village projects implemented using ESCO } \\
\text { model: } 12.75 \% \text { with term loan up to } 80 \% \text { of project cost } \\
\text { New instrument: Loan against securitization of future cash flow of } \\
\text { renewable energy projects } \\
\text { Implementation agency for finance scheme for off-grid projects under } \\
\text { JNNSM }\end{array}$ \\
\hline PFC & $\begin{array}{l}\text { Provides term loans to all entities (government and IPPs) for power } \\
\text { generation (from conventional and renewable energy projects), } \\
\text { transmission, and distribution }\end{array}$ \\
\hline $\begin{array}{l}\text { Rural Electrification } \\
\text { Corporation Ltd }\end{array}$ & $\begin{array}{l}\text { Provides loans for all entities (government and independent power } \\
\text { producers) for the purpose of rural electrification, irrespective of nature, } \\
\text { size, or source of energy } \\
\text { Provides short-term loans and debt refinancing to state power utilities in } \\
\text { need of financial assistance to cover rural electrification }\end{array}$ \\
\hline NABARD & $\begin{array}{l}\text { Rural innovation fund for all innovations and related activities in the farm, } \\
\text { rural non-farm, and micro-finance sectors that provide technology, skill } \\
\text { upgrade, inputs supply, and market support for rural entrepreneurs; } \\
\text { assistance is given in the form of loans, grants, or incubation funds } \\
\text { Environmental Promotional Assistance: scheme for eco-friendly } \\
\text { technologies including biogas, solar, and biofuels } \\
\text { Scheme for home lighting through solar energy }\end{array}$ \\
\hline
\end{tabular}

The different types of businesses, stages of technology or project development, and degrees of risk associated with investments in renewable energy require different types of investors. At the early stage, when there is no track record and no revenues are generated, the most common form of financing is the entrepreneur's private capital. This normally involves borrowing from friends and family. However, there are also funds available through research and academic institutions, government initiatives, grants and foundations, and within 
corporate R\&D departments. ${ }^{447}$ Some identified early stage financiers that are actively supporting renewable energy $R \& D$ in India are:

- ICICI Technology Finance Group.

- Techno-Entrepreneurship Promotion Program.

- Indian Institutes of Technology and other universities.

- Corporate R\&D departments.

- Centre for Innovation Incubation and Entrepreneurship.

- The Indian Angel Network.

In addition to providing financial support, these financiers may undertake mentoring and capacity building, upgrading and expanding facilities, or bringing in collaborative partners for R\&D and business development.

Venture capital is focused on "early stage" or "growth stage" technology companies, while private equity firms tend to look at more mature technologies or projects. They generally expect to exit their investment and make their returns in a 3- to 5-year timeframe. ${ }^{448}$ Although Indian venture capital activity is increasing, there are still only a few venture capital investors in India who are actively looking to invest in renewable energy companies. One of the latest deals was from the first quarter of 2010; Azure Power, a solar power plant developer, raised INR 500 million (USD 10 million) in equity funding from IFC, Helion Advisors, and Foundation Capital. ${ }^{449}$ Other companies such as Climate Change Capital, Infrastructure Development Finance Company, and FE Clean Energy have created separate funds for clean energy. On the private equity side, with lower cash flows expected in the initial years of renewable energy projects, there is great need for equity funding for construction and expansion. Thus, there appears to be significant scope to attract private equity funds, provided that investment packages are suitably structured and the market offers high, expected returns. Suzlon Energy is an example of a successful private equity investment in renewable energy in India. In 2004, the company attracted private equity investment for funding its expansion plans. Today it is a publicly listed company, having made its initial public offering in 2005 . $^{450}$

Corporate financing involves the use of internal company capital to finance a project directly or the use of internal company assets as collateral to obtain a loan from a bank or other lenders. Corporate financiers of renewable energy projects in India are primarily concentrated on large wind and hydropower projects, where captive power generation and the application of accelerated depreciation benefits play a significant role. ${ }^{451}$ Project financing is a method of

\footnotetext{
${ }^{447}$ Cleantech AustralAsia. Pursuing Clean Energy Business in India 2008; pp. 23-24. http://www.asiapacificpartnership.org/pdf/REDGTF/RDG-06-10_Report.pdf. Accessed August 2010. 448 Justice, S.; Hamilton, K. "Private Financing of Renewable Energy-A Guide for Policymakers." http://www.energy-base.org/fileadmin/media/sefi/docs/publications/Finance guide FINAL-.pdf. Accessed October 2010.

${ }^{449}$ International Finance Corporation. http://www.ifc.org/ifcext/media.nsf/content/SelectedPressRelease?OpenDocument\&UNID=DDE16356C70731 57852576EE004C8047. Accessed August 2010.

${ }^{450}$ Ernst \& Young. "Renewable Energy in India-Charting Rapid Growth." 2007. https://eyo-iispd.ey.com/drivinggrowth/unprotected/downloads/Renewable_Energy_in_India_Charting_Rapid_Growth.pdf. Accessed October 2010.

${ }^{451}$ New Energy India. http://www.newenergyindia.org/Finance\%20Page.htm. Accessed August 2010.
} 
financing a project through debt and equity that are repaid by the revenues and assets of a specific project rather than through the balance sheet of a company. The primary debt providers in renewable energy project financing are commercial banks. For a long time, Indian domestic banks were shy to lend to the sector. There were perceived technological risks, risks related to PPAs, and risks associated with escalating project costs. However, as the market matured and more favorable government policies passed, banks have become increasingly more comfortable funding renewable energy projects at attractive interest rates.

Prominent domestic banks that currently fund renewable projects are: Industrial Development Bank of India (IDBI), Export-Import Bank of India, ICICI Bank, the Industrial Finance Corporation of India (IFCI), State Bank of India, Yes Bank, and PNB. ICICI Bank, India's largest private sector lender, has been funding renewable energy projects for years. Currently, ICICI provides a $50 \%$ waiver on loan processing for green vehicles and green homes. ${ }^{452}$ Yes Bank, another example, has set aside nearly $20 \%$ of its infrastructure to lend to fund clean technology projects; it recently approved a loan of INR 1 billion (USD 20 million) for wind farm equipment supplied by Enercon, which operates under the independent power producer model. $^{453}$

In the so-called "bottom of the pyramid" market, a number of microfinance institutions (MFIs) provide credit to individual borrowers or to local NGOs to give them access to responsive and timely financial services at market rates, to repay their loans, and to use the proceeds to increase their income and assets. MFIs facilitate the purchase of renewable energy systems like solar cookers, solar lanterns, or small biogas plants in off-grid areas of the country. The Self Employed Women's Association is perhaps the most well-known example of an MFI in India. Also, a number of government organizations and private banks provide financial assistance to small- and medium-sized enterprises (SMEs). The various financial services and products provided in the field of microfinance and SME finance are summarized in Tables 9-3 and 9-4.

\footnotetext{
${ }^{452}$ ICICI Bank. http://www.icicibank.com/pfsuser/webnews/go-green/Index.html. Accessed August 2010.

${ }^{453}$ Singh, M. "Investors, Banks Willing to Go Green Again." The Times of India. http://timesofindia.indiatimes.com/biz/india-business/Investors-banks-willing-to-go-greenagain/articleshow/5861547.cms. Accessed August 2010.
} 
Table 9-3. Commercial Banks and their Services

\begin{tabular}{|l|l|}
\hline \multicolumn{1}{|c|}{ Indian Commercial Banks } & \multicolumn{1}{c|}{ Type of Financing } \\
\hline Bank of Baroda & Infrastructure financing \\
\hline Bank of Maharashtra & $\begin{array}{l}\text { Infrastructure financing } \\
\text { Energy equipment financing (solar energy, bioenergy, and clean } \\
\text { energy programs) }\end{array}$ \\
\hline Canara Bank & $\begin{array}{l}\text { SME financing } \\
\text { Infrastructure financing } \\
\text { End-user financing }\end{array}$ \\
\hline Corporation Bank & Infrastructure financing \\
\hline Export - Import Bank of India & $\begin{array}{l}\text { Technology financing } \\
\text { Infrastructure financing }\end{array}$ \\
\hline ICICI Bank & $\begin{array}{l}\text { Infrastructure financing (green homes) } \\
\text { Transport financing (green cars) }\end{array}$ \\
\hline IDBI Bank & $\begin{array}{l}\text { Carbon credit business } \\
\text { SME financing } \\
\text { Infrastructure financing }\end{array}$ \\
\hline IFCI & Venture Capital (acquired stake in Luminous Teleinfra Limited) \\
\hline Indian Overseas Bank & Infrastructure financing \\
\hline ING Vysya Bank Ltd. & Infrastructure financing \\
\hline Laxmi Vilas Bank & Infrastructure financing \\
\hline Punjab National Bank & Infrastructure financing \\
\hline State Bank of Bikaner and Jaipur & Infrastructure financing \\
\hline State Bank of India & Infrastructure financing \\
\hline Axis Bank & $\begin{array}{l}\text { Infrastructure financing } \\
\text { Private equity (acquired a minority stake in a south India clean } \\
\text { energy firm) }\end{array}$ \\
\hline
\end{tabular}


Table 9-4. Microfinance Institutions and Initiatives

\begin{tabular}{|c|c|}
\hline Institution Name & Type of Microfinance \\
\hline Aryavart Gramin Bank & $\begin{array}{l}\text { Approved loans for the installation of } 8,000 \text { solar-home systems in } \\
\text { Uttar Pradesh }\end{array}$ \\
\hline Grameen Surya Bijlee Foundation & $\begin{array}{l}\text { Helps fund solar lamps and home and street lighting systems for } \\
\text { villages in India, Nepal, and Bangladesh }\end{array}$ \\
\hline $\begin{array}{l}\text { Green Microfinance and } \\
\text { MicroEnergy International launch } \\
\text { Energizing India, with the help of } \\
\text { the Evangelical Social Action } \\
\text { Forum }\end{array}$ & $\begin{array}{l}\text { Provides micro-energy products for its clients (micro-businesses and } \\
\text { families) in four provinces in south India through micro-loans }\end{array}$ \\
\hline HSBC and Micro Energy Credits & $\begin{array}{l}\text { Provides clean energy alternatives to clients of Spandana (enables } \\
\text { them to access the global carbon credit market) }\end{array}$ \\
\hline $\begin{array}{l}\text { Renewable Energy and Energy } \\
\text { Efficiency Partnership (REEEP), } \\
\text { TERI, and Clinton Climate } \\
\text { Initiative }\end{array}$ & Replaces kerosene and paraffin lanterns with solar devices \\
\hline REEEP 455 & Developing 10 renewable energy projects with microfinancing \\
\hline $\begin{array}{l}\text { Self Employed Women's } \\
\text { Association }\end{array}$ & $\begin{array}{l}\text { Provides affordable renewable energy sources to poor people, e.g., } \\
\text { solar-powered batteries }\end{array}$ \\
\hline SKS Microfinance & Offers solar lamps (to women) \\
\hline
\end{tabular}

\subsection{International Support}

The Indian renewable energy sector has received significant support from the international community in the form of grants and low-interest loans. Several international financial institutions and bilateral financial institutions are engaged in renewable energy financing in India, such as World Bank/IFC, KfW, Nordic Investment Bank, United Nations Environment Programme (UNEP), ADB, USAID, and Danish International Development Agency (DANIDA). Their activities are summarized in Table 9-5, some of which are discussed more in detail below.

\subsubsection{World Bank/International Finance Corporation}

The World Bank's annual lending to India's power sector is approximately INR 50 billion (USD 1 billion). The World Bank is supporting the efficient transmission and distribution of power to consumers; in September 2009, they extended a loan of INR 50 billion (USD 1 billion) to Powergrid to strengthen and expand five transmission systems in the northern, western, and southern regions of the country, and they are also supporting transmission and distribution improvements in Haryana and Maharashtra. Through the Bank's private sector arm, the IFC, a loan of INR 312 million (USD 6.25 million) was approved for renewable energy company Auro Mira Energy Company Private Limited to build an 18 MW biomassbased power plant. ${ }^{456}$ In 2010, IFC also provided a INR 3.8 billion (USD 75 million) loan to

\footnotetext{
${ }^{454}$ More information on this microfinance initiative, http://southasia.oneworld.net/fromthegrassroots/microfinance-for-solar-power. Accessed October 2010, ${ }^{455}$ More information on this microfinance initiative, http://southasia.oneworld.net/fromthegrassroots/microfinance-for-solar-power. Accessed October 2010. ${ }^{456}$ International Finance Corporation. http://www.ifc.org/ifcext/spiwebsite1.nsf/1ca07340e47a35cd85256efb00700cee/72FBCEFEF801C2D7852576C E0058DB18. Accessed August 2010.
} 
Infrastructure Development Finance Corporation (IDFC) for investments in renewable energy, cleaner production, and energy efficiency projects. ${ }^{457}$

\subsubsection{KfW}

Since the 1950s, more than EUR 8 billion (INR 480 billion/USD 9.6 billion) have been channeled by KfW on behalf of the German government, mainly for the fields of energy, finance sector development, health, and protection of the environment and natural resources. Currently, 12 energy sector projects, with KfW loan commitments of more than EUR 1.2 billion (INR 70 billion/USD 1.4 billion), are being implemented in India. In 2009, KfW signed an agreement with IREDA to provide financial assistance of EUR 19.97 million (INR 1.20 billion/USD 24.00 million) for the promotion of biomass power generation in India. The loan aims to accelerate the adoption of environmentally sustainable biomass power and cogeneration technologies in India and promotes innovative biomass projects of combustion, gasification, methanation, and cogeneration technologies for electricity generation. ${ }^{458}$

\subsubsection{United Nations Environment Programme}

The 4-year, INR 380 million (USD 7.6 million) India Solar Loan Program was launched in 2003 through a partnership between UNEP, the UNEP Risø Centre on Energy, Climate and Sustainable Development, and two of India's largest banking groups, with support from the UN Foundation and Shell Foundation. It aimed to establish a consumer credit market for financing solar home systems in southern India. The innovative financing arrangement involved an interest rate reduction, market development support, and a process to qualify solar suppliers. The interest rate reduction was phased out during the program and after project completion. Further financing of solar home systems is on purely commercial terms. While the solar home sector was a small, cash-only business in 2003, today the market is growing with more than $50 \%$ of sales financed by banks. There are now more than 20 banks with networks of more than 2,000 branches offering solar financing. ${ }^{459}$

\subsubsection{Asian Development Bank}

ADB's energy sector program includes support for enhancing the impact of the Government of India's initiatives in the renewable energy sector. There are many ongoing ADB lending programs targeting various renewable energy activities in different states in India. For instance, ADB is providing almost INR 7.5 billion (USD 150 million) in loans to support five wind power projects totaling over $260 \mathrm{MW}$ in Maharashtra, Gujarat, and Karnataka. In line with its Asian Solar Energy Initiative, ADB is presently supporting MNRE in implementation of JNNSM, and planned activities include support for the development of large-scale (1$3 \mathrm{GW}$ ) solar power parks in the states of Gujarat and Rajasthan. ADB's private sector operations is also preparing an INR 7.5 billion (USD 150 million) guarantee facility to mobilize commercial financing for an aggregate $100 \mathrm{MW}$ of small grid-connected solar projects and is also evaluating direct lending for larger solar PV and solar thermal projects in India. $^{460}$

\footnotetext{
${ }^{457}$ International Finance Corporation. http://www.ifc.org/ifcext/spiwebsite1.nsf/f451 ebbe34a9a8ca85256a550073ff10/90a9316abecfa8448525770700 62fca0?opendocument. Accessed August 2010.

${ }^{458}$ For more information, please visit http://www.german-info.com/press shownews.php?pid=1725.

${ }^{459}$ For more information on the UNEP Solar Loan Programme, please visit http://www.unep.fr/energy/activities/islp/overview.htm.

${ }^{460}$ Tan, V. ADB. Personal Communication. September 29, 2010.
} 
Table 9-5. Bilateral and Multilateral Institutions and Services

\begin{tabular}{|c|c|}
\hline Name of Institution & Type of Financing \\
\hline ADB & $\begin{array}{l}\text { - Private sector financing-equity, loans, and guarantees } \\
\text { - Technical Assistance Special Fund }\end{array}$ \\
\hline World Bank and IFC & $\begin{array}{l}\text { - Infrastructure financing (IFC)-first commercial utility solar } \\
\text { project in India to Azure Power Private } \\
\text { - } \\
\text { Microfinancing-INR } 453 \text { million (USD } 9.05 \text { million) grant to } \\
\text { Small Industries Development Bank of India } \\
\text { - Private sector funding } \\
\text { - Renewable energy financing and commercial market } \\
\text { improvements (with Global Environment Facility); the project } \\
\text { allowed IREDA to promote and finance private-sector renewable } \\
\text { investments } \\
\text { - World Bank and USAID loan disbursement by ICICI Bank }\end{array}$ \\
\hline $\begin{array}{l}\text { Global Environment Facility } \\
\text { (GEF) }\end{array}$ & 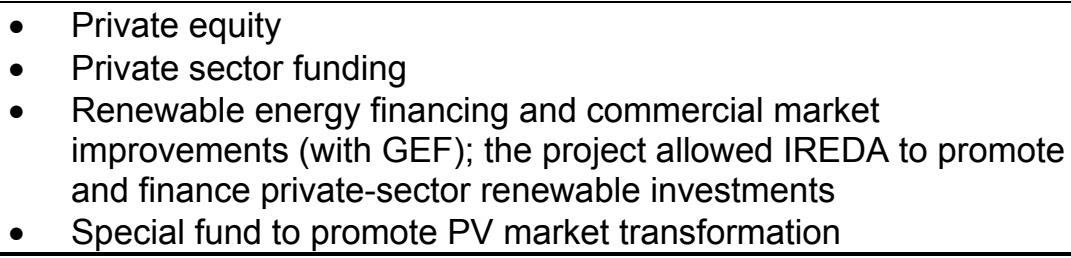 \\
\hline $\mathrm{KfW}$ & $\begin{array}{l}\text { - Lines of credit to Indian finance institutions-IREDA, PFC, REC } \\
\text { - Technology financing } \\
\text { - } \quad \text { Microfinancing } \\
\text { - SME financing }\end{array}$ \\
\hline DANIDA & $\begin{array}{l}\text { - Infrastructure financing-wind power } \\
\text { - Soft loans } \\
\text { - Technology financing }\end{array}$ \\
\hline USAID & $\begin{array}{l}\text { - Venture capital fund-initiated by Indian financial institutions to } \\
\text { support clean technology activities in the private marketplace } \\
\text { - } \quad \text { Infrastructure financing } \\
\text { - World Bank and USAID loan disbursement by ICICI Bank }\end{array}$ \\
\hline Nordic Investment Bank & $\begin{array}{l}\text { - Line of credit of INR } 2.5 \text { billion (USD } 50 \text { million) for financing of } \\
\text { renewable energy projects }\end{array}$ \\
\hline
\end{tabular}

\subsection{Clean Development Mechanism ${ }^{461}$}

The first phase of Kyoto Protocol aims at bringing the GHG levels in the atmosphere to 5.4\% below the 1990 level by the year 2012. UNFCCC has identified three mechanisms under the Kyoto Protocol to enable the reduction of GHG emissions in a cost-effective approach. CDM is one of the flexible mechanisms by which this can be achieved through GHG emissions trading between the Annex I countries (mainly industrialized countries) and Non-Annex I countries under the climate change convention. ${ }^{462}$ Financing is one of the major hurdles faced by emission reduction projects and the primary goal of the CDM is making financing available to such projects to encourage sustainable development. With the provision of the CDM principle, India could sell achieved emission reductions credits to developed countries.

India began participation in the CDM in 2003, and as an early entrant has been an active and significant participant using revenues of carbon credits to finance renewable energy projects. India has the second largest market share of CDM projects after China; the CDM executive board had registered 506 projects in India as of June 2010, which amounted to more than

\footnotetext{
${ }^{461}$ India's participation in CDM is also discussed in Chapter 1.

${ }^{462}$ For a description of Annex I and Non-Annex I countries, see the UNFCCC's parties and observers: http://unfccc.int/parties and_observers/items/2704.php.
} 
$20 \%$ of all the registered projects. ${ }^{463}$ In the initial stage of CDM development in India, biomass utilization projects, waste gas/heat utilization projects, and other renewable energy technology projects (largely wind and hydropower) were mainly being implemented, though India also has registered CDM projects for other sectors including energy efficiency, afforestation and reforestation, and transportation. Figure 9-1 shows the contributions of various project categories to India's CDM portfolio.

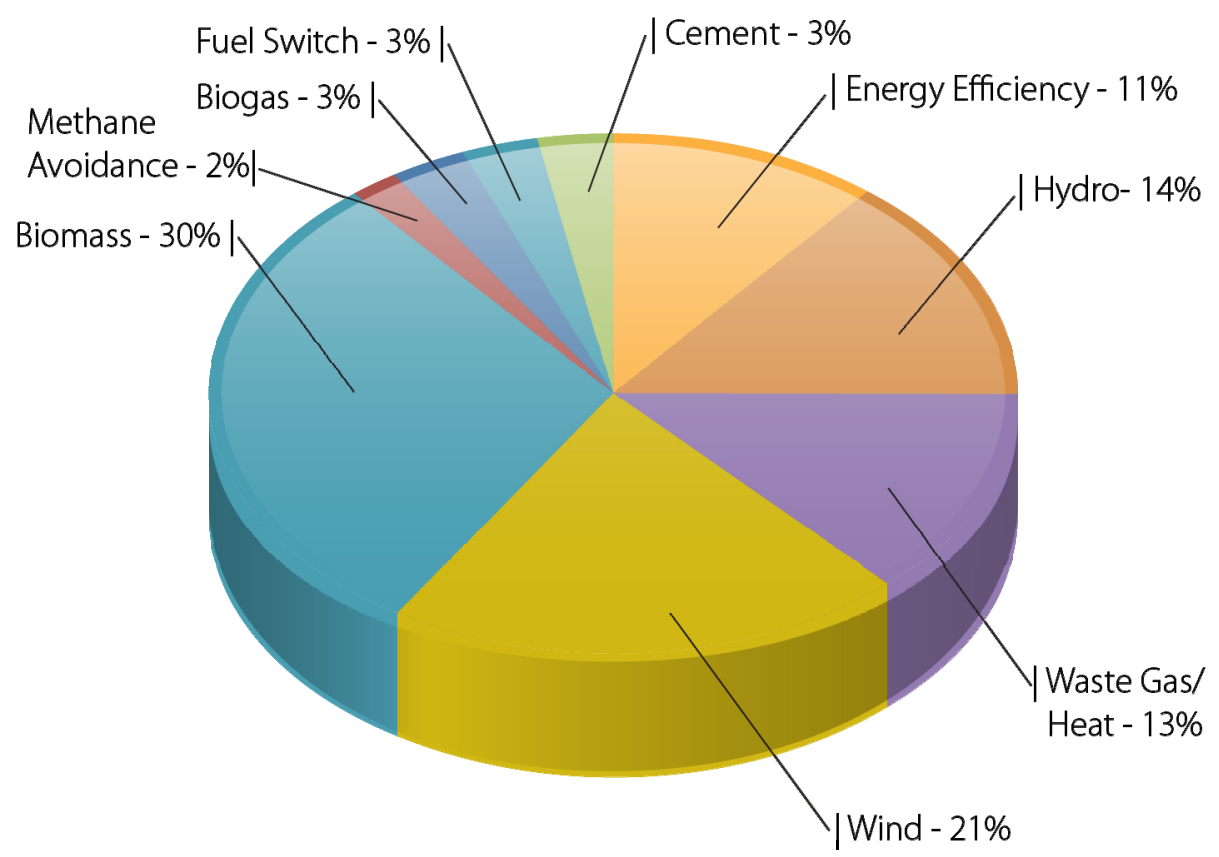

Figure 9-1. Types of registered CDM projects in India ${ }^{464}$

There are also a large number of unilateral CDM projects, approximately 422 projects as of June $2010,{ }^{465}$ which are being developed by Indian stakeholders without the technological or financial engagement of Annex I industrialized countries. Indian project developers implement the project by the bearing transaction costs of CDM and taking on the project risks.

In the past few years, a large number of renewable energy projects have benefited from the CDM process. With the development of programmatic and sectoral CDM, it is expected that more small-scale renewable energy projects will be bundled together to tap the revenue from international emission trading.

\footnotetext{
${ }^{463}$ Institute for Global Environmental Strategies.

http://enviroscope.iges.or.jp/modules/envirolib/upload/984/attach/india_final.pdf. Accessed August 2010.

${ }^{464}$ Institute for Global Environmental Strategies.

http://enviroscope.iges.or.jp/modules/envirolib/upload/984/attach/india final.pdf. Accessed August 2010. Chart is produced from its original figure.

${ }^{465}$ Institute for Global Environmental Strategies.

http://enviroscope.iges.or.jp/modules/envirolib/upload/984/attach/india final.pdf. Accessed August 2010.
} 


\section{Enabling Environment}

\section{Chapter Overview}

Future success in achieving ambitious renewable energy goals will require supportive policies, innovative financing availability, and technology growth. The International Renewable Energy Conference (IREC) series brings together stakeholders to discuss the conditions that have supported successful renewable energy deployment, the challenges still being faced, and creative solutions. An increasing number of countries are setting targets for renewable generation at the national and sub-national levels. In addition and as an alternative, countries are setting preferential tariffs to deploy technologies that cannot yet compete on costs with traditional fossil technologies. Governments are increasing their fiscal support for renewable energy in a variety of ways including funds for demonstration projects and loan guarantees. Public sector international financial institutions are playing a larger role in supporting clean energy projects relative to private financial institutions, though the latter are still active participants and may increase their role again as global financial markets recover. At the same time that renewable energy is receiving this policy and fiscal support, the technologies themselves are continually improving and the costs coming down. So as India and other nations gather for DIREC 2010 and look ahead to the next gathering in the series, there are many opportunities to share experiences that have contributed to renewable energy growth to-date and prospects for more rapid growth in the coming years.

\subsection{History of the International Renewable Energy Conference Process}

Since the initiation of the first IREC in Bonn, Germany, in 2004, this conference series has achieved high-level, international participation of stakeholders from policy, business, science, and civil society. The Bonn "Renewables 2004" and the subsequent Beijing International Renewable Energy Conference (BIREC 2005) and Washington International Renewable Energy Conference (WIREC 2008) provided important inputs for the international discourse on renewable energy.

Renewables 2004 charted the way towards an expansion of renewable energy technologies worldwide, responding to the call of the Johannesburg summit for the global development of renewable energy in 2002. It also kept up the momentum generated by a group of likeminded countries for promotion of renewable energy. Renewables 2004 addressed the issue of how the proportion of renewable energy can be substantially increased and how its advantages and potential can be better used.

The conference concentrated in particular on the following themes:

- Formation of enabling political framework conditions, allowing the market development of renewable energy.

- Increase in private and public financing in order to secure reliable demand for renewable energy.

- Human and institutional capacity building and coordination and intensification of $R \& D$.

BIREC in November 2005 called on the world to consider renewable alternatives in the era of high oil prices. The political commitment to encourage the use of fossil fuel alternatives was strengthened by the messages from the Chinese President and the General Secretary of the United Nations to the 1,200 representatives from more than 80 countries and regions. 
WIREC was held March 4-6, 2008, in Washington, D.C. WIREC was a collective effort, involving public and private partners, both domestic and international. Building on the two preceding conferences, WIREC again brought together the world's leaders in the field of renewable energy to reconfirm the commitment to a cleaner energy future. In partnership with REN21, WIREC gathered 145 specific, policy-oriented initiatives that will significantly increase the presence of renewable energy worldwide.

DIREC 2010, with special focus on "Upscaling and Mainstreaming Renewables for Energy Security, Climate Change, and Economic Development," is the fourth in the series of the global ministerial-level conferences on renewable energy. The Government of India hosts this international platform for government, private sector, and civil society leaders to jointly address the goal of advancing renewable energy. It will build upon the success and outcomes of the previous events in Bonn, Beijing, and Washington, D.C.

\subsection{International Policy Landscape}

Currently, 83 countries promote the use of renewable energy resources through national and regional policies, and this number continues to increase. These policies include feed-in tariffs, renewable obligations or quotas, capital subsidies or grants, investment tax credits, sales tax or value added tax exemptions, green certificate trading, direct energy production payments or tax credits, net metering, direct public investment or financing, and public competitive bidding. Apart from the national level, local governments and even cities play a role. ${ }^{466}$

The effectiveness of the policies depends on the governments' abilities to commit towards renewable energy in the long term, to install legally binding targets, and to improve while continually building on past experiences. To enhance the impact, most countries use a combination of different policies at the national, state, and regional levels.

As Asian countries improve their policies on and commitment for renewable energy, the leadership in this market is shifting from West to East, especially to China who added the largest renewable energy capacity of $37 \mathrm{GW}$ in 2009 and to India. ${ }^{467}$

\subsubsection{Policy Targets}

National policies can set targets for the share of renewable energy in total electricity, primary or final energy mix. The first period for targets ends in 2012, but new policies aim at a longterm commitment until 2020 and beyond. ${ }^{468}$

An example for such a policy is the agreement of the 27 countries of the EU to follow an EUwide target. The EU stated that by $2020,20 \%$ of their final energy mix should be produced

\footnotetext{
${ }^{466}$ REN21. "Renewables 2010 Global Status Report.” Paris: REN21 Secretariat. 2010. http://www.ren21.net/globalstatusreport/REN21_GSR 2010 full.pdf. Accessed October 2010.

${ }^{467}$ Goldman Sachs Global Market Institute. "Alternative Energy: Prospects for Policy, Finance and Technology.” June 2009. http://www2.goldmansachs.com/ideas/global-markets-institute/past-research-andconferences/past-research/alt-energy-doc.pdf. Accessed October 2010.

${ }^{468}$ REN21. "Renewables 2010 Global Status Report.” Paris: REN21 Secretariat. 2010. http://www.ren21.net/globalstatusreport/REN21 GSR 2010 full.pdf. Accessed October 2010.
} 
by renewable energy resources. ${ }^{469}$ In some countries, such as in the United States and Canada, targets are set on a state or regional level. ${ }^{470}$

In the case of countries such as India who have double-digit growth rates in energy demand, ${ }^{471}$ setting percent targets is ambitious. Nonetheless, both countries have set themselves targets. India's Eleventh Plan sets a renewable energy capacity target of $25 \mathrm{GW}$ by 2012, and JNNSM aims for installed on-grid solar alone to reach $20 \mathrm{GW}$ by $2022 .{ }^{472}$

The policy targets are communicated and discussed on an international level during global conferences such as DIREC. The International Renewable Energy Agency (IRENA) will support the efforts of different countries to achieve their stated targets. ${ }^{473}$

\subsubsection{Renewable Energy Promotion Policies}

The most common promotional policies are preferential feed-in tariffs. They are implemented in 50 countries and have been effective at speeding up the deployment of renewable energy technologies, particularly in the wind sector. ${ }^{474}$

In recent years, many countries have modified their tariffs based on prior experience and changes in the market. China, for example, based its new tariffs for wind power on competitive bidding and project development experience. Furthermore, it developed a system of different tariffs for different regions of the country based on the availability of renewable energy resources. ${ }^{475}$ In some countries, such as Spain, the reduction of technology costs and growing global competition led to the announcement of lower tariffs. ${ }^{476}$

National policies for quotas on renewable energy or renewable portfolio standards exist only in 10 countries (Australia, Chile, China, Italy, Japan, the Philippines, Poland, Romania, Sweden, and the United Kingdom), but these are more common on the state/provincial level, especially in the United States and India. Most of these policies target a share of renewable energy power in the range of $5 \%-20 \% .{ }^{477}$

Direct capital investment subsidies or grants are offered either for a broad range of renewable energy technologies, as in Indonesia and the Philippines, or are technology specific, as in India's income tax exemption for wind projects. Recently, the import duties were reduced in

\footnotetext{
${ }^{469}$ Europa press release. "Memo on the Renewable Energy and Climate Change Package." http://europa.eu/rapid/pressReleasesAction.do?reference=MEMO/08/33. Accessed September 11, 2010.

${ }^{470}$ REN21. “Renewables 2010 Global Status Report.” Paris: REN21 Secretariat. 2010. http://www.ren21.net/globalstatusreport/REN21_GSR 2010 full.pdf. Accessed October 2010.

${ }^{471}$ Liming, H. "Financing Rural Renewable Energy: A Comparison between China and India." Institute of South Asian Studies Working Paper. 23 May 2008.

http://www.frankhaugwitz.info/doks/general/2008_05_23_China_RE_Finance_Comparison_India.pdf. Accessed October 2010.

472 See Chapters 2 and 4 of this report.

${ }^{473}$ IRENA. http://www.irena.org/ourMission/index.aspx?mnu=mis. Accessed September 11, 2010.

${ }^{474}$ REN21. "Renewables 2010 Global Status Report.” Paris: REN21 Secretariat. 2010. http://www.ren21.net/globalstatusreport/REN21_GSR_2010_full.pdf. Accessed October 2010.

${ }_{475}$ Mendonca, M. "Feed-In Tariffs: Accelerating the Deployment of Renewable Energy." 2007.

${ }^{476}$ Hughes, E. "Spain Feed-in Tariff Cuts: New Photovoltaic Solar Power Plants to be Chopped by up to $45 \%$." PV-Tech. http://www.pv-tech.org/news/_a/spain_feedin tariff cuts new phot35654654 plants to be chopped by up to 45/. Accessed September 11, 2010.

${ }^{477}$ REN21. "Renewables 2010 Global Status Report” Paris: REN21 Secretariat. 2010. http://www.ren21.net/globalstatusreport/REN21 GSR 2010 full.pdf. Accessed October 2010.
} 
many countries to remove this barrier to the growth of renewable energy. An example is South Korea, where duties have been reduced by $50 \% .{ }^{478}$

The solar PV market, especially PV rooftop programs, is often supported by capital subsidies, which usually cover $30 \%-50 \%$ of the installation costs. In South Korea, as much as $70 \%$ of the cost is subsidized and a goal of $300 \mathrm{MW}$ from rooftop PV by 2011 was announced. In China, half of the capital costs of building-based solar PV larger than $50 \mathrm{~kW}$ and on-grid projects of more than $300 \mathrm{~kW}$ are subsidized. ${ }^{479}$

Tradable RECs are well established in the EU and in some U.S. states. The European Energy Certificate System consists of 18 countries and provides a platform for the issue and transfer of voluntary RECs as well as guarantee-of-origin certificates. ${ }^{480}$

Public investment, low-interest loans or financing is considered to be an important aspect for growth in the renewable energy sector. Therefore, many countries have established renewable energy funds. One of these is the Canadian CAD 1 billion clean energy fund (INR 45 billion/USD 987 million) that supports the demonstration of projects as well as R\&D. ${ }^{481} \mathrm{New}$ funds have come up in China, the Philippines, Bangladesh, and Jordan. In India, the establishment of a National Clean Energy Fund is part of the Indian Budget 2010-2011.482

Public competitive bidding policies involve bidding for fixed quantities of renewable energy capacity. One of the oldest examples of this policy, China's bidding policy for wind projects, is being replaced by feed-in tariffs. American countries, such as Brazil, Uruguay, and Argentina, launched competitive bidding programs in 2008-2009.483

\subsection{New Financing Methods}

The total investment in renewable energy capacity in 2009 was INR 7,500 billion (USD 150 billion). Venture capital and private equity investment went down mainly as a result of the global financial crisis. At the same time, governments increased the investment in research, development, and deployment. Germany and China were the investment leaders in 2009, each spending around INR 1,250-1,500 billion (USD 25-30 billion). Wind power received $62 \%$ of the total investment in utility-scale power plants. Investments in PV declined, mainly due to falling module prices. ${ }^{484}$

An interesting model to meet the demand for risk-mitigation is the insurance for CDM projects. The insurers guarantee that CERs will be delivered on agreed terms and conditions to the client or they will provide financial compensation. This reduces the risk for project

\footnotetext{
${ }^{478}$ Chan, Y. "South Korea Slashes Import Tariffs on Renewable Energy Equipment." Business Green. http://www.businessgreen.com/business-green/news/2249866/south-korea-slashing-import._Accessed September $11,2010$.

${ }^{479}$ Renewable Power News. "Ways to Encourage Governmental Support for Solar Power." http://www.renewablepowernews.com/archives/1610. Accessed September 11, 2010.

${ }^{480}$ REN21. "Renewables 2010 Global Status Report.” Paris: REN21 Secretariat. 2010. http://www.ren21.net/globalstatusreport/REN21 GSR 2010 full.pdf. Accessed October 2010.

${ }^{481}$ Natural Resources Canada. http://www.nrcan.gc.ca/media/newcom/2009/200943-eng.php. Accessed September 11, 2010.

${ }^{482}$ Key Features of Budget 2010-2011. http://indiabudget.nic.in/ub2010-11/bh/bh1.pdf. Accessed September 2010.

${ }^{483}$ REN21. “Renewables 2010 Global Status Report.” Paris: REN21 Secretariat. 2010. http://www.ren21.net/globalstatusreport/REN21 GSR 2010 full.pdf. Accessed October 2010.

${ }^{484}$ REN21. "Renewables 2010 Global Status Report.” Paris: REN21 Secretariat. 2010. http://www.ren21.net/globalstatusreport/REN21 GSR 2010 full.pdf. Accessed October 2010.
} 
developers, investors, and buyers of CERs. Institutions offering this service are the Austrian Garant Insurance, the French Global Sustainable Development Project, and Swiss Re Greenhouse Gas Risk Solutions. The first insurance was implemented in South America and covers a carbon delivery guarantee, political risk insurance, and business interruption. ${ }^{485}$

The last years have seen significant "green stimulus packages" that include grants, loans, loan guarantees, tax credits, tax deduction, and other supporting schemes. With INR 3,345 billion (USD 68.7 billion), China leads the investments, followed by the United States with INR 3,330 billion (USD 66.6) billion and EU with INR 565 billion (USD 11.3 billion). The green stimulus funding has so far suffered from delays in the administrative processes. To bring the funds to bear more quickly, they can be injected by development banks. The Japan Bank of International Cooperation, for example, has set up an INR 250 billion (USD 5 billion) fund for environmental projects in Asia. The French development bank, Agence Française de Dévellopement, plans to invest INR 520 billion (USD 10.4 billion) in infrastructure projects. ${ }^{486}$

While public sector banks and development banks expanded their roles, the commercial banks reduced their exposure. The most important players include the European Investment Bank, the Brazilian National Bank of Economic and Social Development, the World Bank Group, the German KfW, the Inter-American Development Bank, and ADB. ${ }^{487}$

\subsection{Renewable Technology Costs}

Costs for many renewable energy technologies have been falling significantly over the last years, making them more competitive. A good example is solar PV; in the last 12 years, the module costs, which account for about $50 \%$ of total costs, declined due to economies of scale in production. At the same time, non-module costs such as inverters, other hardware, labor, permitting, and shipping also came down. ${ }^{488}$

A main component in the production of PV crystalline cells is polysilicon. The supply of material was constrained and prices doubled from 2004 until 2008. This is not considered a problem, as improvements in utilization and new production capacities lead to the assumption of falling future costs. Regarding thin-film PV, a potential constraint and cost driver could be the supply of some rare metals used for this technology. 489

\subsection{New Technology Development}

In the coming years, we cannot only expect the drops in renewable technologies discussed above, but we can also expect substantial progress with some of the less mature renewable technologies. Some of these technologies are ready to see significant gains, and some may see their utilization rates accelerated by ambitious initiatives of governments and the private sector.

\footnotetext{
${ }^{485}$ UNEPFI. "The Materiality of Social, Environmental and Corporate Governance Issues to Equity Pricing," Asset Management Working Group, Geneva: UNEPFI; June 2004.

${ }^{486}$ UNEP. "Global Trends in Sustainable Energy Investment 2009." http://www.unep.org/pdf/Global trends_report_2009.pdf. Accessed October 2010.

${ }^{487}$ REN21. "Renewables 2010 Global Status Report.” Paris: REN21 Secretariat. 2010. http://www.ren21.net/globalstatusreport/REN21 GSR 2010 full.pdf. Accessed October 2010.

${ }^{488}$ Price, S.; Margolis, R. “2008 Solar Technologies Market Report.” U.S. Department of Energy. http://www.nrel.gov/docs/fy10osti/46025.pdf. Accessed April 9, 2010

${ }^{489}$ Price, S.; Margolis, R. "2008 Solar Technologies Market Report.” U.S. Department of Energy. http://www.nrel.gov/docs/fy10osti/46025.pdf. Accessed April 9, 2010
} 


\subsubsection{Geothermal Power}

Geothermal power plants provide direct heat and electricity. Twenty-four countries currently have geothermal power plants with a total capacity of $10.7 \mathrm{GW}$, but $88 \%$ of it is generated in just seven countries: the United States, the Philippines, Indonesia, Mexico, Italy, New Zealand, and Iceland. The most significant capacity increases since 2004 were seen in Iceland and Turkey. Both countries doubled their capacity. Iceland has the largest share of geothermal power contributing to electricity supply (25\%), followed by the Philippines $(18 \%)^{490}$ The development of advanced technologies is expected in the near future, as well as a rise in the number of installations. Currently, there are many new projects under construction. ${ }^{491}$

\subsubsection{Ocean Energy}

To date, ocean energy is mostly used in pilots and demonstration projects. While tidal and wave technologies are already implemented commercially in a few projects, ocean thermal energy conversion is still in exploration status. The governments of some European states, Australia, South Korea, Canada, and the United States support the growth of the market by grants. Ireland has the largest and most established market with preferential feed-in tariffs for ocean energy. ${ }^{492}$

\subsubsection{Large Grid Networks}

The concept of large grid networks is being promoted by the DESERTEC initiative, which promotes deployment of CSP in desert regions and transport the electricity generated using high-voltage direct current transmission networks. They are supporting CSP development in North Africa with an aim to provide most of the power needs for the Middle East and North Africa and up to $15 \%$ of the power needs of Europe by 2050 . The initiative supports use of a large network of medium transmission lines to move power from North Africa to Europe instead of a few large transmission lines (analogous to the transmission networks for oil and natural gas) to increase security of supply. ${ }^{493}$

\subsubsection{Solar Cooling}

Use of solar thermal systems to supply energy to absorption chillers is being explored as part of several ambitious renewable energy initiatives. The Masdar City project in the United Arab Emirates and the Hawaii Renewable Energy Deployment venture in the United States have both announced plans to utilize the technology to cool buildings. ${ }^{44,495}$ Solar cooling

\footnotetext{
${ }^{490}$ REN21. "Renewables 2010 Global Status Report.” Paris: REN21 Secretariat. 2010. http://www.ren21.net/globalstatusreport/REN21 GSR 2010 full.pdf. Accessed October 2010.

${ }^{491}$ Geothermal Energy Association. "Geothermal Energy: International Market Update." http://www.geoenergy.org/pdf/reports/GEA_International_Market_Report_Final_May_2010.pdf. Accessed September 12, 2010.

${ }^{492}$ REN21. "Renewables 2010 Global Status Report.” Paris: REN21 Secretariat. 2010. http://www.ren21.net/globalstatusreport/REN21 GSR 2010 full.pdf. Accessed October 2010.

${ }^{493}$ DESERTEC. http://www.desertec.org/en/. Accessed September 12, 2010.

${ }^{494}$ MASDAR. "Masdar Turns to Sun's Heat to Cool Buildings." http://www.masdar.ae/en/mediaCenter/newsDesc.aspx?News ID=150\&MenuID=55\&CatID=44. Accessed October 14, 2010.

${ }^{495}$ Hawaii Renewable Energy Development Venture. "Five Clean Energy Companies Receive Funding to Demonstrate Innovative Technologies in Hawaii." http://www.hawaiirenewable.com/wpcontent/uploads/2010/09/HREDV-News-release-Sept-2010.pdf. Accessed October 2010.
} 
technology presents opportunities for many warm climates, including India, where a solar thermal cooling system has already been deployed at the Muni Seva Ashram in Gujarat. ${ }^{496}$

\subsection{Looking Ahead}

As policymakers and renewable energy professionals convene at DIREC, they will be looking at successes since the last IREC in Washington, D.C., and forward to what can be achieved before the next meeting in 2012. Country- and state-level adoption of targets for renewable capacity and generation has increased rapidly in recent years, renewable technologies continue to improve, and deployment of these technologies is continuing in a way that their contribution to the global energy system continues to increase in significance. Policy action in countries like India has resulted in the contribution of increasing renewable energy market growth in developing countries. At the next IREC, India will be poised to present on lessons learned from the first phase of JNNSM and plans for Phase 2, and there may be changes to the Indian manufacturing sector to reflect the industry growth objectives of the mission. If current trends continue, the next IREC will take place amidst a rapid expansion of installed renewable capacity with delivered energy costs continuing their trend toward parity with fossil technologies.

\footnotetext{
${ }^{496}$ Epp, B. "Solar Thermal Based Air-conditioning System Proves Itself in India." http://www.solarthermalworld.org/node/1028. Accessed October 2010.
} 


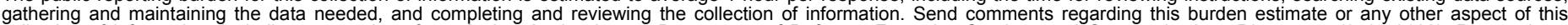

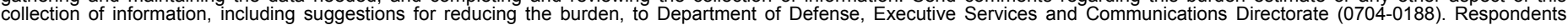

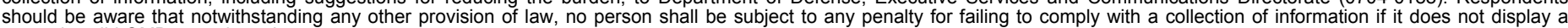

currently valid

PLEASE DO NOT RETURN YOUR FORM TO THE ABOVE ORGANIZATION.

\begin{tabular}{ll|l} 
1. & $\begin{array}{l}\text { REPORT DATE (DD-MM-YYYY) } \\
\text { October } 2010\end{array}$ & $\begin{array}{l}\text { 2. } \\
\text { REPORT TYPE } \\
\text { Technical Report }\end{array}$ \\
\hline $\begin{array}{l}\text { 4. } \\
\text { TITLE AND SUBTITLE } \\
\text { Indian Renewable Energy Status Report: Background Report for } \\
\text { DIREC } 2010\end{array}$
\end{tabular}

\section{AUTHOR(S)}

D. S. Arora (IRADe); Sarah Busche (NREL); Shannon Cowlin (NREL); Tobias Engelmeier (Bridge to India Pvt. Ltd.); Hanna Jaritz (IRADe); Anelia Milbrandt (NREL); Shannon Wang (REN21 Secretariat)

5a. CONTRACT NUMBER

DE-AC36-08-GO28308

5b. GRANT NUMBER 5d. PROJECT NUMBER

NREL/TP-6A2-48948

5e. TASK NUMBER

IGIN.9700
7. PERFORMING ORGANIZATION NAME(S) AND ADDRESS(ES)

National Renewable Energy Laboratory

1617 Cole Blvd.

Golden, CO 80401-3393 5f. WORK UNIT NUMBER

9. SPONSORING/MONITORING AGENCY NAME(S) AND ADDRESS(ES)

8. PERFORMING ORGANIZATION REPORT NUMBER

NREL/TP-6A2-48948
10. SPONSOR/MONITOR'S ACRONYM(S) NREL

11. SPONSORING/MONITORING AGENCY REPORT NUMBER

\section{DISTRIBUTION AVAILABILITY STATEMENT}

National Technical Information Service

U.S. Department of Commerce

5285 Port Royal Road

Springfield, VA 22161

\section{SUPPLEMENTARY NOTES}

\section{ABSTRACT (Maximum 200 Words)}

India has great potential to accelerate use of endowed renewable resources in powering its growing economy with a secure and affordable energy supply. The Government of India recognizes that development of local, renewable resources will be critical to ensure that India is able to meet both economic and environmental objectives and has supported the development of renewable energy through several policy actions. This paper describes the status of renewable energy in India as of DIREC 2010. It begins by describing the institutional framework guiding energy development in India, the main policy drivers impacting energy, and the major policy actions India has taken that impact renewable energy deployment. The paper presents estimates of potential for wind, solar, small hydro, and bioenergy and the deployment of each of these technologies to date in India. The potential for India to meet both large-scale generation needs and provide access to remote, unelectrified populations are covered. Finally, the enabling environment required to facilitate rapid scale of renewables is discussed, including issues of technology transfer and the status of financing in India.

15. SUBJECT TERMS

India; renewable energy; wind; solar photovoltaics; PV; bioenergy; biogas; biofuels; biomass; hydropower; solar water heating; concentrating solar power; climate change; finance

\begin{tabular}{|l|l|l|}
\hline \multicolumn{3}{|l|}{ 16. SECURITY CLASSIFICATION OF: } \\
\hline $\begin{array}{l}\text { a. REPORT } \\
\text { Unclassified }\end{array}$ & $\begin{array}{c}\text { b. ABSTRACT } \\
\text { Unclassified }\end{array}$ & $\begin{array}{l}\text { c. THIS PAGE } \\
\text { Unclassified }\end{array}$ \\
\hline
\end{tabular}

\begin{tabular}{l|l|l} 
17. LIMITATION & 18. NUMBER \\
OF ABSTRACT & OF PAGES \\
UL &
\end{tabular}

19a. NAME OF RESPONSIBLE PERSON

19b. TELEPHONE NUMBER (Include area code) 
Contributors to this Report:

National Renewable Energy Laboratory

1617 Cole Boulevard, Golden, Colorado 80401-3305

Tel: +1 3032753000

http://www.nrel.gov

\section{REN21 Secretariat}

15 rue de Milan

75441 Paris Cedex 9

France

Tel: +33144375094

Fax: +33144375095

E-Mail: secretariat@ren21.net

http://www.ren21.net/

Deutsche Gesellschaft für Technische Zusammenarbeit (GTZ) GmbH Postfach 5180

65726 Eschborn

Germany

Tel: +49 $619679-0$

Fax: +49 $619679-1115$

E-Mail: info@gtz.de

http://www.gtz.de

Integrated Research and Action for Development - IRADe

B-44, Shivalik, Malviya Nagar

New Delhi - 110017

http://www.irade.org

Bridge to India Pvt. Ltd. - Environment Technology, Indian Market S-181 Panchsheel Park

110017 New Delhi/India

Tel: +91 1146081579

E-Mail:info@bridgetoindia.com

http://www.bridgetoindia.com/ 


\section{National Renewable Energy Laboratory}

1617 Cole Boulevard, Golden, Colorado 80401

303-275-3000 • www.nrel.gov

NREL is a national laboratory of the U.S. Department of Energy Office of Energy Efficiency and Renewable Energy Operated by the Alliance for Sustainable Energy, LLC

NREL/TP-6A20-48948・ October 2010

Printed with a renewable-source ink on paper containing at least $50 \%$ wastepaper, including $10 \%$ post consumer waste. 